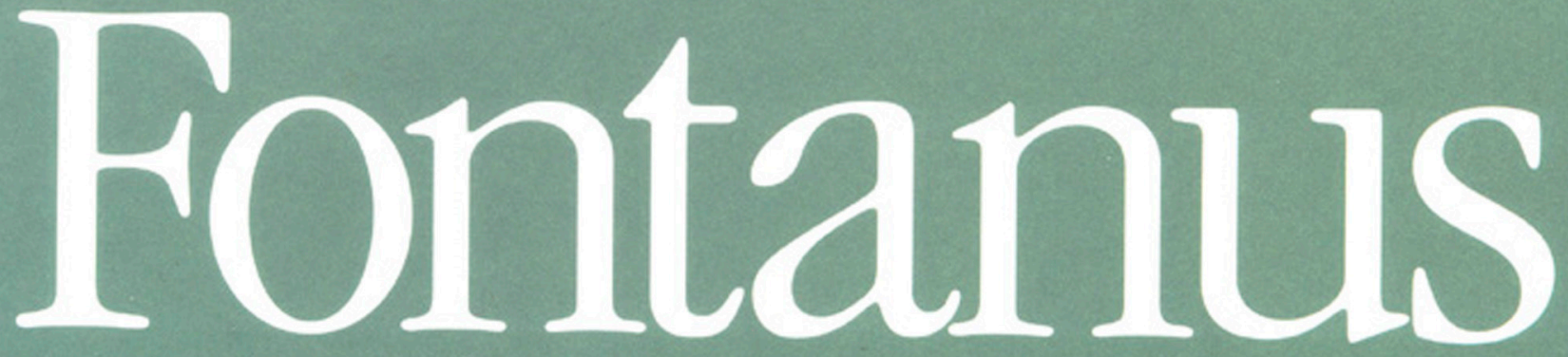

from

the collections of

McGill University

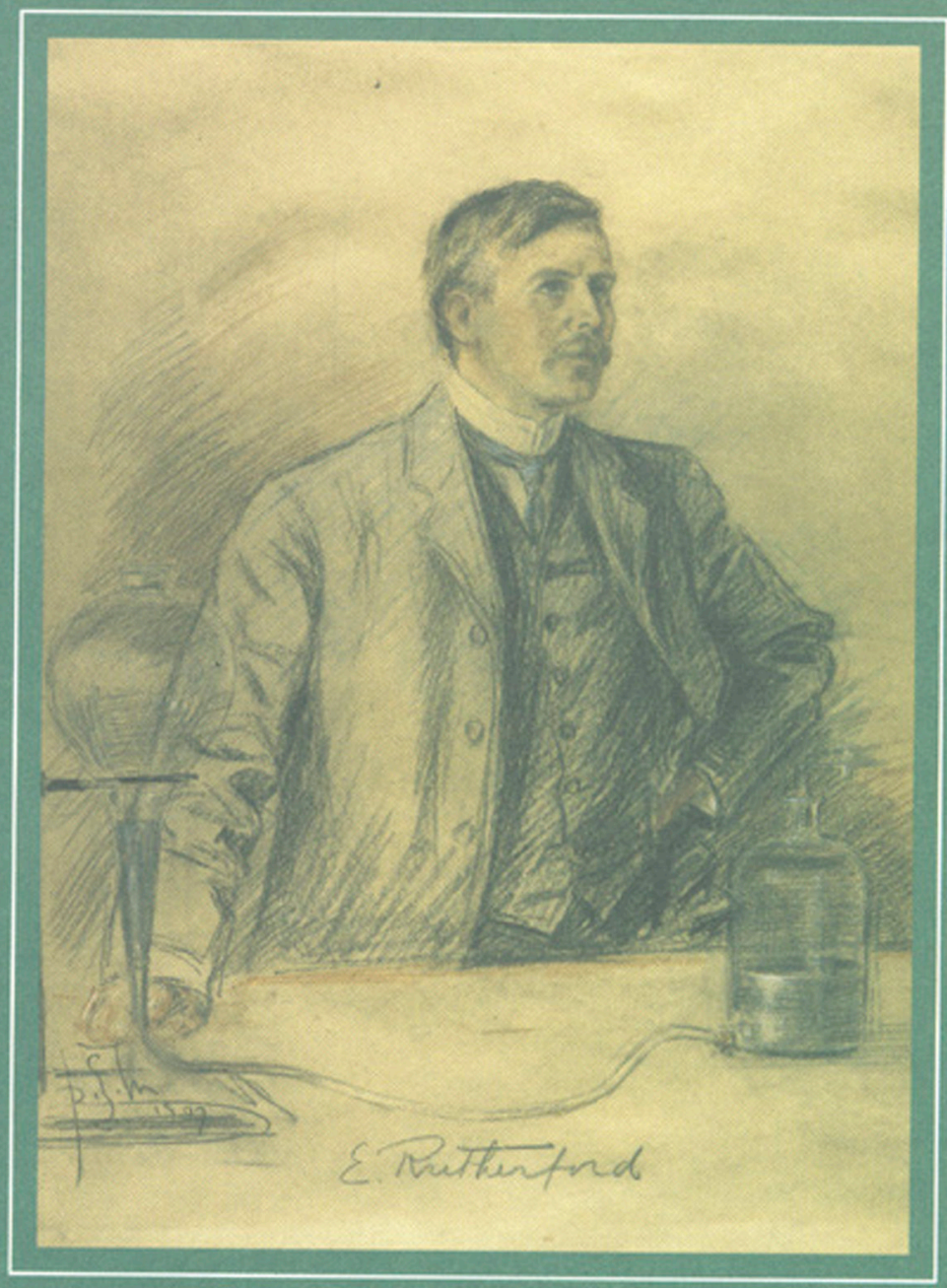


Front Cover: Ernest Rutherford, Pastel Portrait by R.G. Mathews, 1907 (Rutherford Museum, McGill University Physics Department 
Fontanus

from

the collections of

McGill University

volume X 1998 



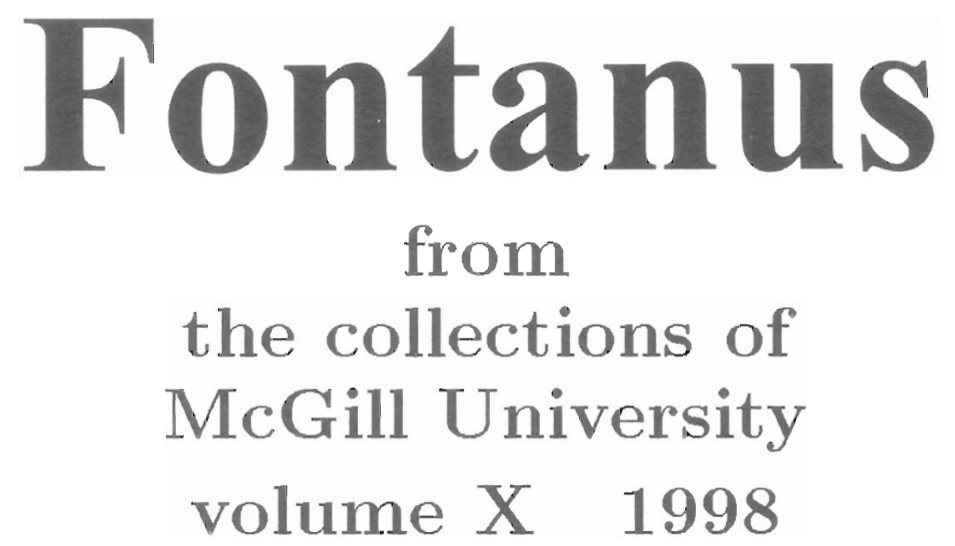

7

Editorial

Montague Cohen

\begin{abstract}
9
Some Thoughts on "Fontanus - From the Collections of McGill University"

Hans Möller
\end{abstract}

11

McGill's Nobel Laureate: The Rutherford Centenary Montaque Cohen

17

McGill University on the Landscape of Canadian

Higher Education: Historical Reflections

Paul Axelrod

35

Not a bad impression: a fine 'Rembrandt' print in McGill's collection

Maria L. Brendel 
41

Ottoman-Turkish Manuscripts in the Islamic and other Libraries of McGill University Adam Gacek and Ali Yaycioğlu

65

Judge Robert Mackay's 1882 Catalogue of Books:

A Preliminary Analysis

P.F. McNally and Christina M. Boyle

71

La Contribution de Maude Abbott au Développement de la Muséologie Médicale (1898-1940)

Hervé Gagnon et Christine D. Nadeau

81

Cultural Diversity and Human Rights

S.J. Toope

93

Print Culture and English-Speaking Quebec

P.F. McNally

101

Canada's Animal Doctor: Duncan McNab McEachran

G. Thomson

110

Notes and Comments

118

Chronicle

136

Contributors

138

Fontanus Publications

140

Guidelines for Authors 
Editor:

Montague Cohen

Editorial Committee:

Martin Cohen

Montague Cohen

Peter Daly

Frances Groen

John Hobbins

Pamela Miller

Hans Möller

Richard Virr

Management Committee:

S.O. Freedman (Chairman)

Philip J. Cercone

Gretta Chambers

Peter Daly

Margaret Gillett

Frances Groen

Carman Miller

Hans Möller

Eric Ormsby

Pamela D. Stewart

Bruce Trigger

Word Processing:

Lynda Corkum

Cover Design:

Instructional Communications Centre, McGill

Printing:

AGMV-Marquis Inc.

Paper:

$\infty$ (acid-free) Finch opaque

cream white, vellum finish $70 \mathrm{lb}$.

Subscription prices 1998:

Institutions: \$35

Individuals: $\$ 25$

(C)McGill University Libraries 1998

ISSN 0838-2026 



\section{Editorial}

This issue of FONTANUS, the tenth, must begin with an explanation and a tribute. The explanation relates to the date of the issue: 1998. Strictly speaking this volume, number 10, should have been published in 1997, but circumstances were against us. Dr. Hans Möller, the Founder and Editor of FONTANUS from its inception in 1988, resigned - or, rather, retired - from this duty and there was an inevitable delay while a new Editor was chosen and persuaded to accept the post. The present issue includes an article by Dr. Möller in which he discusses the origins of FONTANUS.

A tribute to Dr. Möller is appropriate at this point. Hans Möller was born in Copenhagen, Denmark, and was educated at Copenhagen University where he obtained his Ph.D. in Danish Language and Literature in 1945. His early career included the posts of Assistant Keeper in the National Museum and Research Librarian at the Royal Library, both in Copenhagen. In 1955 Hans emigrated to Canada, where he was appointed an Executive Producer of the National Film Board and (in 1974) Chief Librarian of the University of Ottawa.

Hans Möller came to McGill in 1977, when he was appointed an Area Librarian and, in 1984, Director of Libraries. Dr. Möller retired from this post in 1986 but was designated Research and Development Librarian, the appointment he holds today. His many publications include books, articles, films and audio-visual materials. Long may you remain with us, Hans!

That brings me to the last part of this excuse for the late publication of FONTANUS, Volume 10. The search for a replacement for Dr. Möller, to assume the post of Editor, eventually focussed on me! It was a strange decision, but not wholly unwelcome. I am not a Librarian, nor even a member of the Faculty of Arts. As a scientist, I am flattered by the decision, but somewhat apprehensive. The last time I edited a journal was in 1941-43, when I was editor of my school magazine in London, England! You, dear Reader, must judge the wisdom of this appointment. Please show your support by submitting articles for Volume 11 which - I promise! - will be published promptly in 1999.

Montague Cohen 


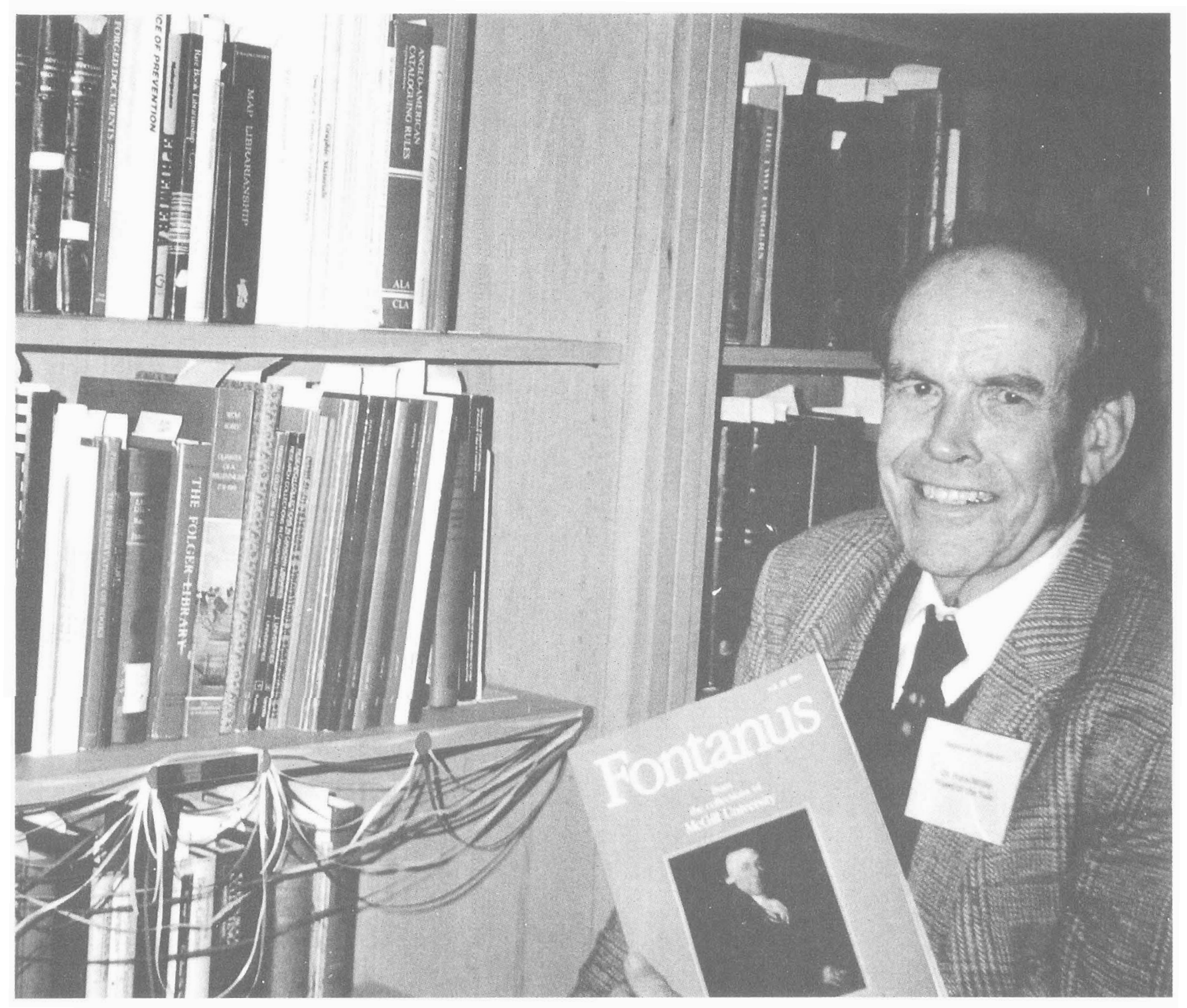




\section{Some Thoughts on "FONTANUS - From the Collections of McGill University"}

\section{by Hans Möller}

The Founder and first Editor of FONTANUS discusses the origin of the journal.

Le fondateur et premier rédacteur en chef de FONTANUS parle de l'origine de la revue.

When I came to McGill in 1977, the very rich, and at times unique, collections in the McGill libraries, archives and museums overwhelmed me. Later, when I stepped down from the position of senior library administrator, Drs. Samuel Freedman, David Johnston and Eric Ormsby asked me what I then most wanted to do. One of my answers was to create a journal with articles about the McGill collections, articles to be written by professional librarians and by scholars in various fields.

Although at the time, librarians had only recently obtained academic status, the idea of such a journal was well accepted. "Try it, but it may prove difficult" was the answer. They meant: difficult to pull librarians and professors together in such a creative effort and difficult to obtain enough material to fill each annual issue.

These fears proved groundless: the journal succeeded and ever since Volume I was published in 1988 we have always had sufficient articles and illustrations for each issue. Both librarians and professors contributed articles of scholarly quality and of value to an intellectual audience.

My original idea for a journal such as FONTANUS goes back to my work in the early 1950s at the Royal Library of Copenhagen, Denmark (the Danish National Library) where I was a member of a team that created an annual journal, just like ours, named FUND OG FORSKNING (Treasures and Research). This journal is still being published today after over 40 years. Its purpose was, and still is, to bring knowledge out of the fabulous collections in that 300-year old library through articles written by librarians and other scholars. I hope FONTANUS annual journal will run at least three hundred years into the future!

Support for FONTANUS grows year by year. It has been described by a noted scholar as "One of the best scholarly journals I know." Chancellor Gretta Chambers and Dean Carman Miller agree that it is unthinkable to have a McGill without FONTANUS. A strong editorial board, with such members as Frances Groen, Director of Libraries, as well as several librarians and professors, has been strong and active support for FONTANUS publications. Dr. Richard Virr has made a remarkable contribution for many years in his role as Associate Editor.

In 1991 it was decided to add a series of monographs under the title FONTANUS MONOGRAPH SERIES. To date, twelve volumes have been published, with the generous support of private donors and foundations. Thus the FONTANUS publications now account for no less than 22 volumes. 


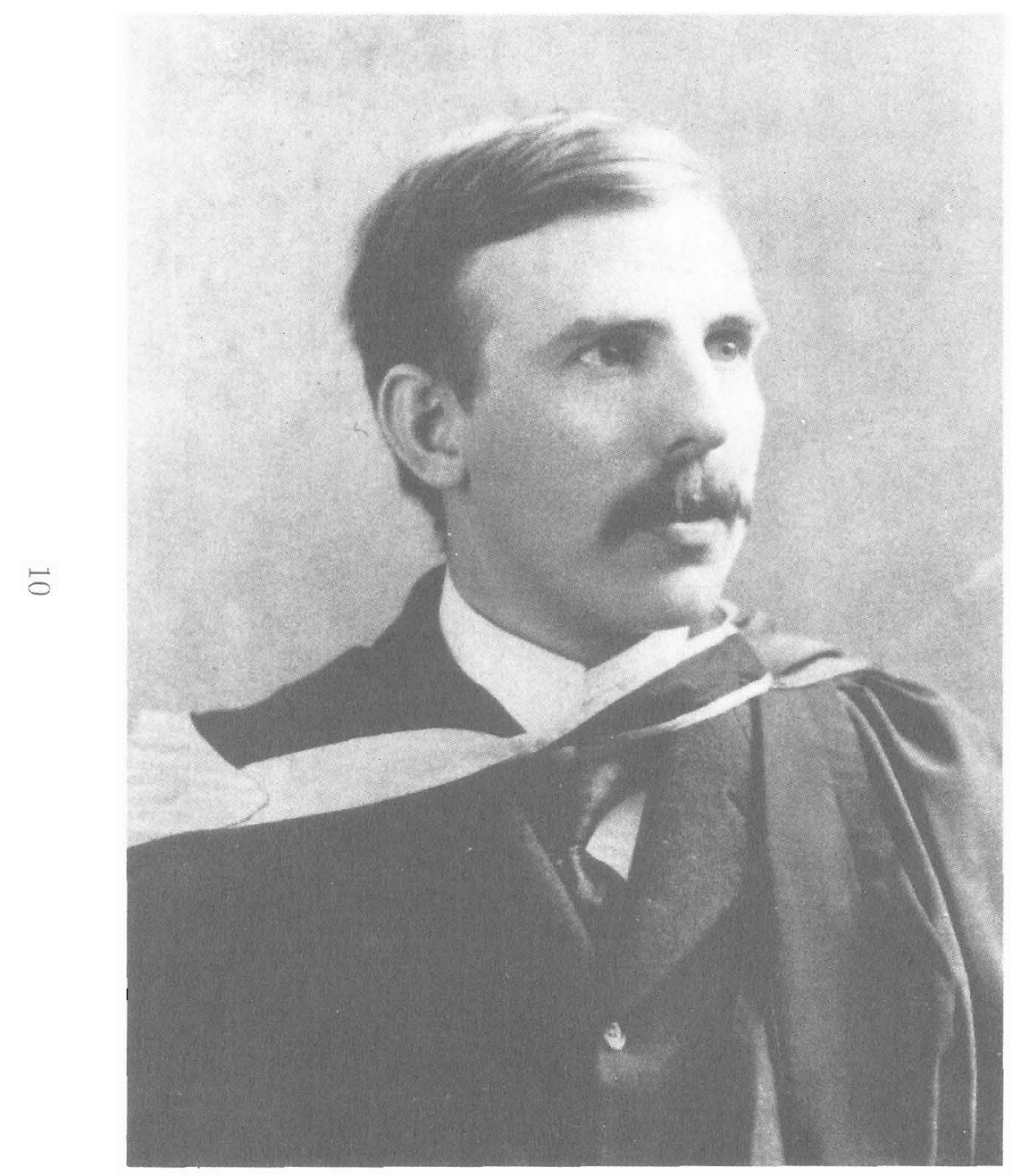

Figure 1. Ernest Rutherford as a young man, c. 1900.

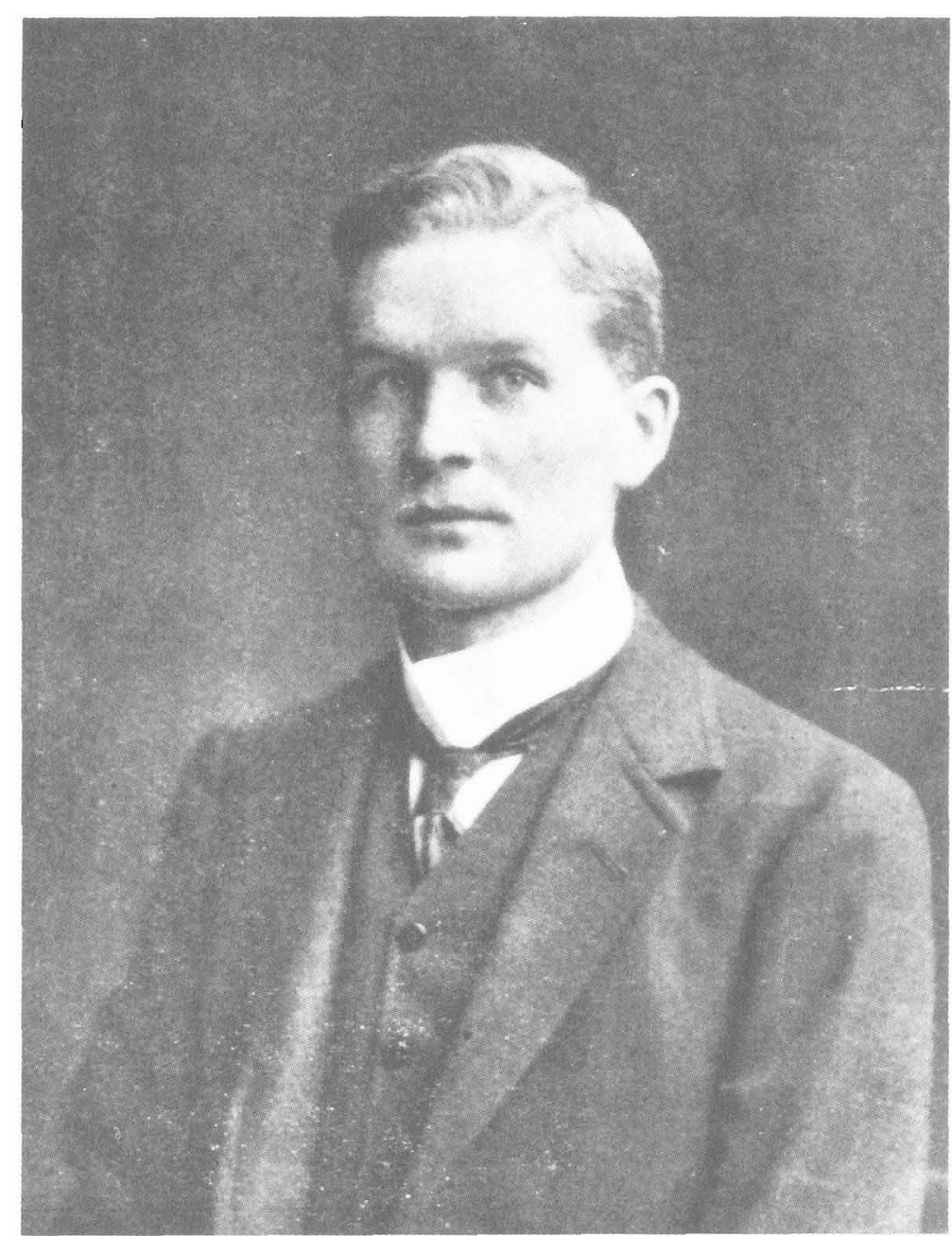

Figure 3. Frederick Soddy 


\section{McGill's Nobel Laureate: The Rutherford Centenary}

\section{by Montague Cohen}

1998 marks the centenary of the appointment of Ernest Rutherford as Macdonald Professor of Physics at McGill University. This article discusses Rutherford's reasons for accepting the post in Canada, and summarizes his research achievements during his nine-year tenure, including the enunciation (with Frederick Soddy) of the transformation theory of radioactivity.

1998 marque le centenaire de la nomination d'Ernest Rutherford à la chaire Macdonald de physique à l'Université McGill. Cet article expose les raisons qui ont poussé Rutherford à accepter ce poste au Canada et donne un aperçu des recherches qu'il y a menées pendant neuf ans, notamment la formulation (avec Frederick Soddy) de la théorie des transformations radioactives.

\section{Arrival in Montreal}

On September 22, 1898, a young New Zealand scientist (Fig. 1) landed in Montreal, after a slow and stormy voyage across the Atlantic and along the St. Lawrence River. Ernest Rutherford, the newlyappointed Macdonald Professor of Physics at McGill University, was ready and anxious to continue the research in the new field of "radioactivity" which he had begun as an 1851 Science Scholar at Cambridge University.

Why did Rutherford agree to come to McGill? ("Agree" rather than "apply" because the post had been offered to him without a prior application on his part.) Nowadays this question would be considered strange, even insulting, but in 1898 it posed a real problem for a scientist in the early stage of his career. The centre of science at that time was firmly in Europe, including the U.K., and communication was such that it was a definite advantage for a young scientist to work at or near the centre.

From Rutherford's point of view the McGill post offered several important advantages. Firstly, he be- came a Full Professor at the age of 27, a promotion virtually impossible in the U.K. (His mentor, J.J. Thomson, for example, was 37 when he was appointed Cavendish Professor of Physics at Cambridge.) Secondly, the annual salary of $£ 500$ (or $\$ 2,500$ ) was very good, and Rutherford needed the money since he was engaged to be married. Thirdly, the Physics Laboratory at McGill - it was not yet designated a Department - was housed in a new building, opened in 1893, thanks to the generosity of the tobacco millionaire William Macdonald, and was reputed to be one of the finest science buildings in the world, perhaps even the finest. Furthermore, the building was generously equipped and Macdonald was willing to finance the purchase of further equipment as required - an undertaking he did, in fact, fulfil. Finally, the post was essentially a Research Professorship and this was what Rutherford wanted.

The Chairman of the McGill Physics Laboratory, Professor John Cox, was an excellent teacher but an indifferent researcher: he was happy to bear the brunt of the teaching load. ${ }^{1}$ Nevertheless it is clear

\footnotetext{
${ }^{1}$ At this time very few Canadian students attended physics courses in order to become professional pbysicists. However,
} 
Figure 2. Exponential decrease in radioactive emission measured by Rutherford in $1900^{1}$ (Curve A), accompanied by corresponding growth in the decay product ( Curve B ).
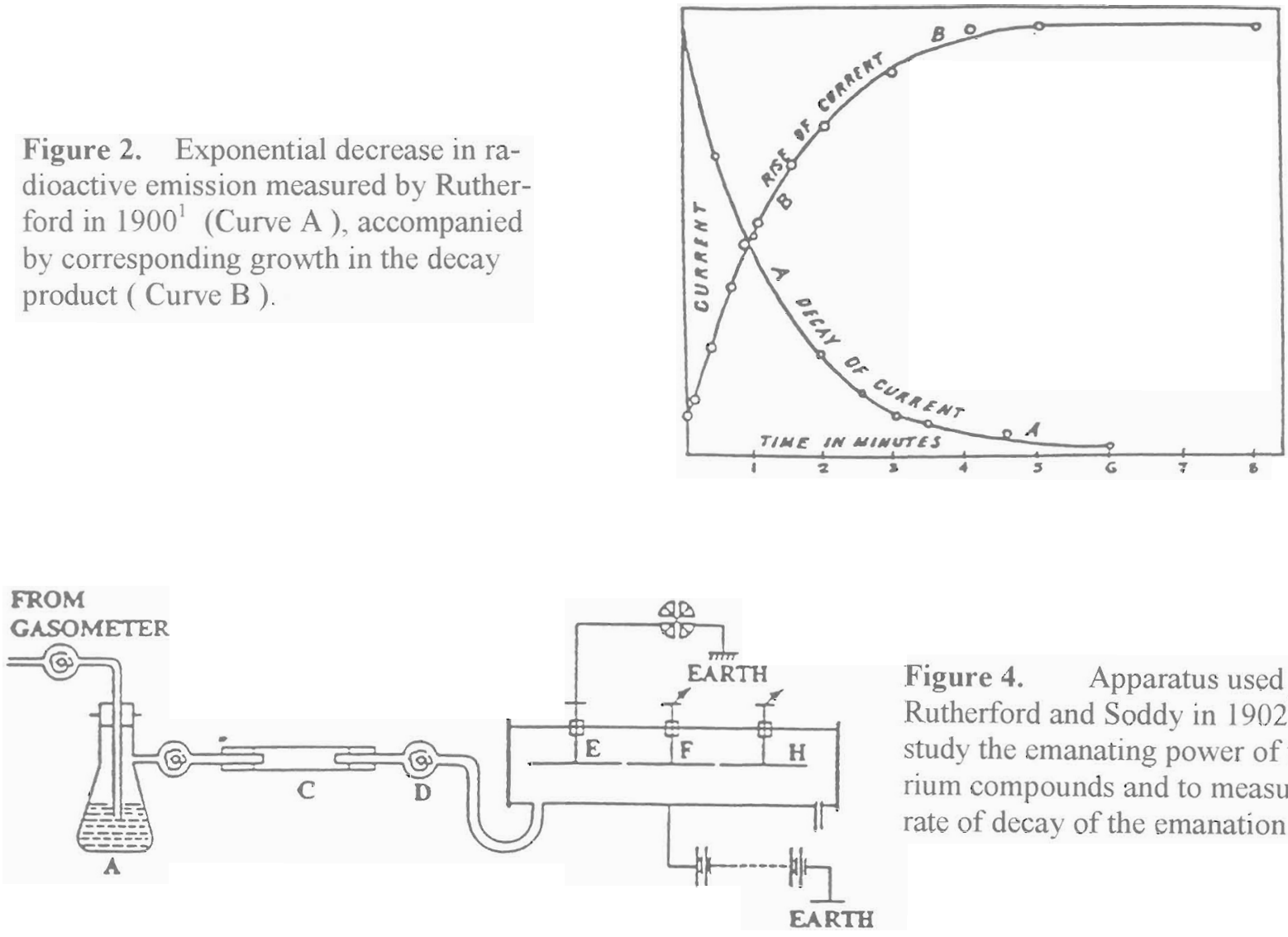

Figure 4. Apparatus used by Rutherford and Soddy in $1902^{2}$ to study the emanating power of thorium compounds and to measure the rate of decay of the emanation

Figure 5. Apparatus used Rutherford in $1903^{3}$ to prove that $\alpha$ - rays are positively charged particles.

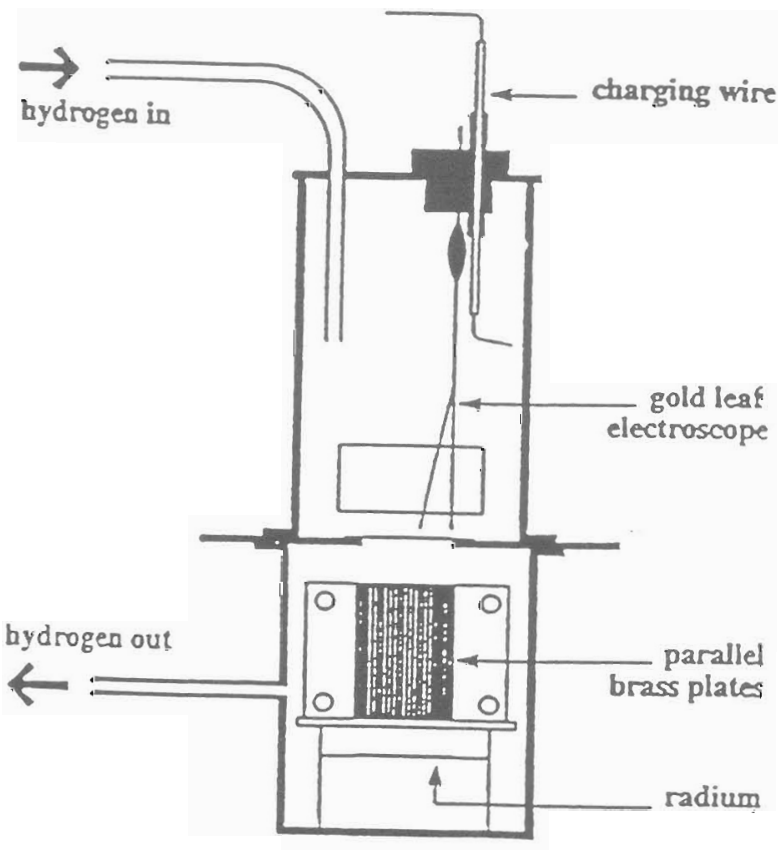


from Rutherford's letters to his parents and fiancée that he did not intend to stay at McGill for as long as nine years: three or four years certainly, perhaps even five, but definitely not nine!

\section{Research at McGill}

Rutherford's research at McGill may conveniently be divided into four periods, which will be discussed briefly as follows:

\section{$1898-1902$}

Rutherford elucidated the basic properties of radioactivity, including the emission during the radioactive process of two different kinds of radiation, which he termed alpha and beta rays. (There is good evidence that Rutherford was aware of the emission of a third radiation, the gamma rays, but the formal discovery of this radiation is usually attributed to the French scientist Paul Villard in 1900.) Rutherford showed that radioactive emission by a given element decreases exponentially with time, while the decay product increases according to the same law (Fig. 2). ${ }^{1} \mathrm{He}$ demonstrated that "emanation," i.e. radon, gives rise to a radioactive deposit on surfaces with which it is in contact. During this period Rutherford also studied the energy and penetrating power of the radiations emitted during the radioactive process.

\section{2-1903}

In collaboration with the young English chemist Frederick Soddy (Fig. 3), who was a demonstrator in Chemistry at McGill from 1900 to 1903 - although the partnership began only in October 1901 - Rutherford investigated the emanating power of thorium compounds and measured the rate of decay of the emanation (Fig, 4). ${ }^{2}$ (Thorium was much more readily obtained than radium.) Rutherford and Soddy studied the nature of radioactivity and in September/November 1902 enunciated the transformation theory of radioactivitity. ${ }^{3}$ This was a rad-

physics was an integral part of university programs in other fields, including medicine, engineering and chemistry. ical departure from the conviction that the atoms of each element are permanent and indestructible (indeed, the word atom means indivisible). During this period Rutherford showed that the $\alpha$-rays are actually heavy, positively-charged particles, although their precise nature was not elucidated until 1907$08 .^{4}$

\section{3-1905}

In this period Rutherford studied the succession of changes which constitute the radioactive series, whereby uranium is transformed via radium, into lead. In collaboration with his colleague Howard Barnes, Rutherford measured the energy associated with radioactive transformations ${ }^{5}$ and - with another colleague, Arthur Steward Eve - the nature of the gamma rays.

\section{$1905-1907$}

Rutherford's main study during this period was the nature and properties of the alpha-particle. ${ }^{6}$ By this time he had acquired a small research group; members of which investigated the radioactivity of the earth and the atmosphere, and made a detailed study of the radioactive series by chemical separation and physical measurements.

\section{Rutherford and the Curies}

Rutherford was not, of course, the only pioneer in the field of radioactivity. The other outstanding scientists were the Curies, Pierre and Marie, but their contribution was of a somewhat different nature: they were mainly concerned with the isolation and identification of the radioactive elements, including radium and polonium, whereas Rutherford was interested in the nature and mechanism of radioactivity. Rutherford met the Curies first in 1903 and, after Pierre's tragic death in 1906, Rutherford interacted with Marie on several occasions and assumed the role of "a calm, gentle, supportive friend, almost fatherly, although he was four years her junior."7 
Figure 6. Apparatus used by RutherFord and Barnes in $1904^{4}$ to measure the energy (heat) generated per second by a known mass of radioactive material.
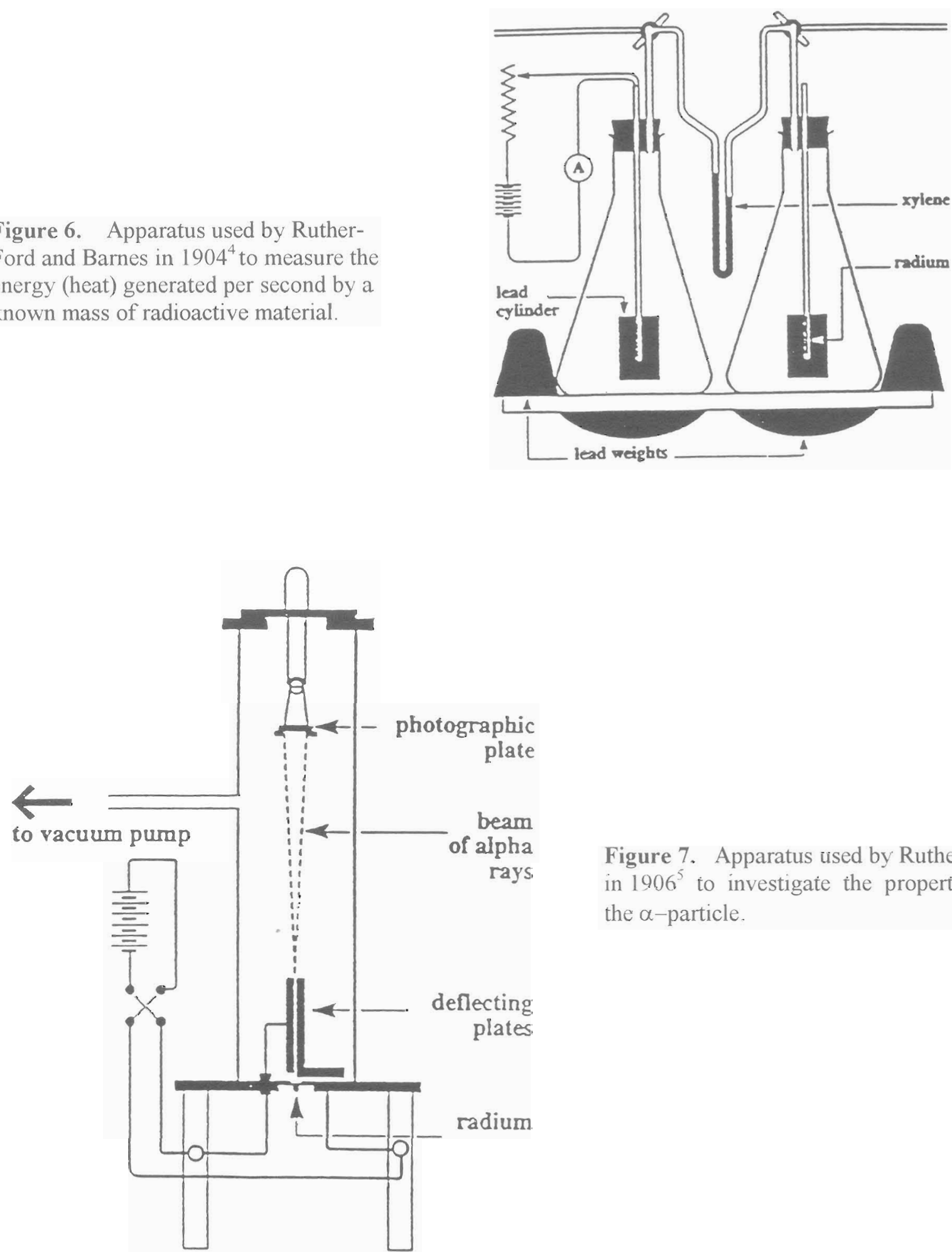

Figure 7. Apparatus used by Rutherford in $1906^{5}$ to investigate the properties of the $\alpha$-particle. 


\section{Rutherford leaves McGill}

In 1907 Rutherford was offered, and accepted, the post of Longworth Professor of Physics at Manchester University in England. In 1908 he was awarded a Nobel Prize (in Chemistry, not Physics) for his "investigations into the disintegration of elements and the chemistry of radioactive substances." Rutherford commented informally that he had observed many transformations with various time periods, but none quite as fast as his own from physicist to chemist! Although Rutherford was no longer at McGill, the research for which the prize was awarded was carried out in Montreal and we are justified in claiming him as McGill's Nobel Laureate.

Rutherford remained at Manchester until 1919, when he was appointed Cavendish Professor of Physics at Cambridge, a post he held until his death in 1937. Although he carried out, or supervised, important research at Manchester and Cambridge, including the development of the nuclear model of the atom in 1911-13, there is no doubt that his most productive period was that at McGill. It can be said, without exaggeration, that Rutherford's research at McGill laid the foundation of 20th century physical science.

\section{The Rutherford Museum}

In the period of Rutherford's work at McGill, scientific apparatus was usually fairly simple in design - although by no means simplistic in concept - and was constructed in the machine shop located in the Physics building. At the end of the investigation the apparatus was returned to the workshop, where it would be dismantled so that many of the components could be re-used in subsequent apparatus. This was the case with Rutherford's apparatus until 1900, when his colleague Howard Barnes pointed out that Rutherford was a pioneer in a new field of science and was already world-famous; it would be a crime against posterity to destroy his apparatus. The equipment was therefore put away in a cupboard where it remained, undisturbed, until the late 1930s.
After Rutherford's death, in 1937, his friend and former colleague, Arthur Stewart Eve, was asked by the Royal Society to write the "official" biography. For this purpose photographs of the apparatus were taken and the idea of a museum was born. The concept lay dormant until 1950, when Dr. Ferdinand Terroux, a lecturer (subsequently Professor) in Physics at McGill made a formal proposal to Dr. Norman Shaw, the Chairman of the Physics Department, for the construction of a "Rutherford $\mathrm{Mu}$ seum and Conference Room." However, no progress was made until 1964, when Dr. Shaw bequeathed $\$ 2,000$ to establish the Museum and an additional sum was provided by the McGill Graduates' Society. A room was allocated in the Macdonald Physics Building and Dr. Terroux undertook the laborious work of repairing, cleaning and renovating the items, while Dr. Terroux's architect son prepared the display graphics. The Museum was opened in October 1967.

\section{Acknowledgement}

By kind permission of Multimed Inc., and the Editors of Current Oncology, this article is published simultaneously in Volume 5 (1998) of the journal Current Oncology.

\section{Notes}

N.B. The papers listed below are only a small fraction of Rutherford's publications during his 9-year tenure at McGill. The full list comprises 51 full papers plus 19 short notes and letters to Nature, totalling over 750 pages of print.

1. Rutherford, E. A radioactive substance emitted from thorium compounds. Phil Mag 1900; ser. 5, 49: $1-14$.

2. Rutherford, E. and Soddy, F. The radioactivity of thorium compounds. Part I. An investigation of 
the radioactive emanation. Trans Chem Soc 1902; 81: 321-350.

3. Rutherford, E. and Soddy, F. The cause and nature of radioactivity. Phil Mag 1902; ser. 6, 4: 370-396 and 569-585.

4. Rutherford, E. The magnetic and electric deviation of the easily absorbed rays from radium. Phil Mag 1903; ser. 6, 5: 177-187.

5. Rutherford, E. and Barnes, H.T. Heating effect of the radium emanation. Phil Mag 1904; ser. 6, 7: 202-219.

6. Rutherford, E. The mass and velocity of the $\alpha$ particles expelled from radium and actinium. Phil Mag 1906; ser. 6, 12: 348-371.

7. Wilson, D. Rutherford. A Simple Genius. Cambridge, MA: MIT Press, 1983; 254.

\section{Bibliography}

Rutherford. Being the Life and Letters of the Rt. Hon. Lord Rutherford, O.M., by A.S. Eve (Cambridge Univ. Press, 1939.)

Lord Rutherford, by Norman Feather. (Priory Press, 1940.)

Rutherford - Recollections of the Cambridge Days, by Mark Oliphant. (Elsevier Publishing Co., Amsterdam and London, 1972.)

The Self-Splitting Atom. A History of the Rutherford-Soddy Collaboration, by Thaddeus J. Trenn. (Taylor and Francis, London, 1977.)

Rutherford and Physics at the Turn of the Century, edited by Mario Bunge and William R. Shea (Dawsun and Science History Publications, New York, 1979.)
Rutherford. Simple Genius, by David Wilson. (M.I.T. Press, Cambridge, Mass., 1983.)

Ernest Rutherford, in Radiological Physicists, by Juan A. del Regato, pp. 37-49 (American Inst. of Physics, New York, 1985.)

My Dear Eve...The Letters of Ernest Rutherford to Arthur Stewart Eve, by Montague Cohen. Fontanus, 1, 3-37 (1988); 2, 111-138 (1989); 느, 69108 (1991); $\underline{5}, 123-159$ (1992).

Rutherford's Curriculum Vitae, 1894-1907, by Montague Cohen. Medical Physics, 22, 841-859 (1995).

Ernest Rutherford and Frederic Soddy: An Historic Partnership, by Montague Cohen. The Chemical Intelligencer, April 1997, 33-40 (Springer-Verlag, New York.)

Rutherford and Soddy: The Cause and Nature of Radioactivity, by Montague Cohen. Ceramic Transactions, 87, 149-158 (1998). 


\section{McGill University \\ on the Landscape of \\ Canadian Higher Education: Historical Reflections*}

\section{by Paul Axelrod}

This article discusses the place of McGill University on the landscape of Canadian higher education in the early twentieth century and attempts to identify some of McGill's unique characteristics. In probing this issue, the author examines selected themes in the academic, administrative and extra-curricular life of the institution, and concludes with some speculative comments about the university's future.

Cet article porte sur la place que l'Université McGill occupait dans l'enseignement supérieur canadien au début du XX $X^{e}$ siècle et tente d'identifier certaines des caractéristiques uniques de McGill. L'auteur se penche sur certains aspects de la vie universitaire, administrative et para-universitaire de McGill et formule quelques hypothèses sur l'avenir de l'Université.

$\mathrm{H}$ development of individual universities in Canada, but their work has rarely been informed by a comparative perspective. While the differences between Canadian and American higher education have drawn. some recent scholarly interest, ${ }^{2}$ academics are still inclined to explore university life through the prism of the single institutional case study in which the experiences of other universities are referenced minimally.

The discussion of McGill University in this article was written for presentation at a 175th anniversary event, and does not escape the institutionalist genre. However, its attempt to identify some unique

\footnotetext{
"This article has been published previously in Higher Educotion Perspectives, Vol. I, 1996/97, a journal of the Higher Education Group, The Ontario Institute for Studies in Education, University of Toronto, and is reproduced here by kind petnission of the Higher Education Group.
}

characteristics of McGill arises from a comparative question: in the early twentieth century, what was McGill's place on the landscape of Canadian higher education? In probing this issue, I examine selected themes in the academic, administrative, and extracurricular life of the institution, and conclude with some speculative comments about the university's future.

\section{Goals of the Canadian University}

Who attended universities in Canada at the turn of the twentieth century and why did they do so? While answers to these questions are far from definitive, case studies of Queen's and Dalhousie suggest that the children of clergy, professionals, merchants, managers and civil servants were particularly well represented among the student body. In addition, more than 30 per cent of Queen's students between 1895 and 1900 were from farming families. Their 
economic status was unclear, though it is likely that they were relatively well off. That not all Canadian students were the progeny of affluence is indicated by the fact that 16 per cent of Queen's registrants were the children of skilled or unskilled workers. ${ }^{3}$

The students aspired to careers in medicine, teaching, engineering, and the ministry. Their actual occupational destinies were somewhat broader. Ultimately, they did indeed work in the areas of health, education and the clergy, but also in science, law, commerce and government. Women graduates who entered the labour force - typically until marriage would find employment in schools, libraries, offices, or as nurses. In most occupational fields, married women were not allowed to continue working and were fired if they did not resign. The Queen's and Dalhousie cases indicate that a higher proportion of university women remained single (and thus employed) than was true of the Canadian female population as a whole.

While we have less detailed information about the origins of McGill students, the national patterns evidently applied there. McGill historian Stanley Frost concluded that, at the beginning of World War I, "the student body was still a compact and homogeneous group of young men and women, mostly from the middle economic strata of society, and of British, or at least anglophone Protestant stock." "If the students' collective profile mirrored the upper end of their communities' class structures, then the average student, at McGill or the University of Toronto was probably somewhat more affluent than his or her counterpart in the more modestly endowed commitinities of Wolfville, Halifax, or Saskatoon. Indeed, at the University of Saskatchewan in 1934, in the midst of the Great Depression, one-third of the students could not afford to pay their tuition fees and instead submitted promissory notes. The situation was by no means so dire at McGill, but during the grim years of the 1930 s, students from poor families, like David Lewis, future parliamentarian and leader of the NDP, could certainly be found.

These trends continued through to at least the Second World War. Canadian students, who in 1930 represented only 3 per cent of their age group, for the most part, came from middle-class families, and through their subsequent occupations or through marriage, they hoped to secure or improve their positions within the middle class. A minority were extremely well off, a minority were poor. Universities were home to a relatively privileged group, but contrary to popular myth, they were not playgrounds of frivolity and ostentation. Neither were they, as charged by one citizen, mere "loafing grounds for rich men's sons," a (1930) comment that among other things, ignored nearly one-quarter of the student body - women. A university education provided the graduate both material opportunity and. the lustre of respectability in an increasingly secular world, though the Depression made it difficult for many students to reap immediately the rewards of. higher learning..

From the perspective of its leaders, the university had a very serious purpose. H.J. Cody, president of the University of Toront, $\mathrm{O}_{3}$ contended that the educated man should be able to "use the mother tongue correctly and precisely," demonstrate "a refinement of manners," be possessed of the "habit and power of reflection," the "ability to grow," and the "power to earn money in the workaday world." McGill spokespersons shared these values. English professor Cyrus MacMillan submitted that "The student who is sent up to college to-day is expected by his parents and those interested in his career to gain along three definite lines: he is to train...his mind...through class-room...study; he is to gain from association with his fellows outside the class-room; [and] he is to benefit from the influence of the college atmosphere on his point of view, his purpose in life, his habits of judgement. These three lines...converge into one main idea - the making of a man," 6 a formula which also ignored university women.

Somewhat less verbosely, Arthur Currie, McGilil's principal from 1920 to 1933, claimed that the university should "place in the plastic minds of the students the seeds of a courageous citzenship...Let students always be devoted to duty."7 Whether one was entering a profession, the business world, or a white-collar occupation, these prescribed qualities were intended to mark the graduate as a. worthy citizen with sound values, lofty morals, enviable education, prized, marketable skills, and the potential of exercising sober community leadership. Though frequently overlooked in convocation addresses, women graduates were also expected by university leaders to contribute to the propriety, refinement and civility of Canadian life, but less as employed workers and professionals than as middle-class wives, domestic organizers, and community volunteers. ${ }^{8}$ Cultivating these myriad attributes was the central mission of 


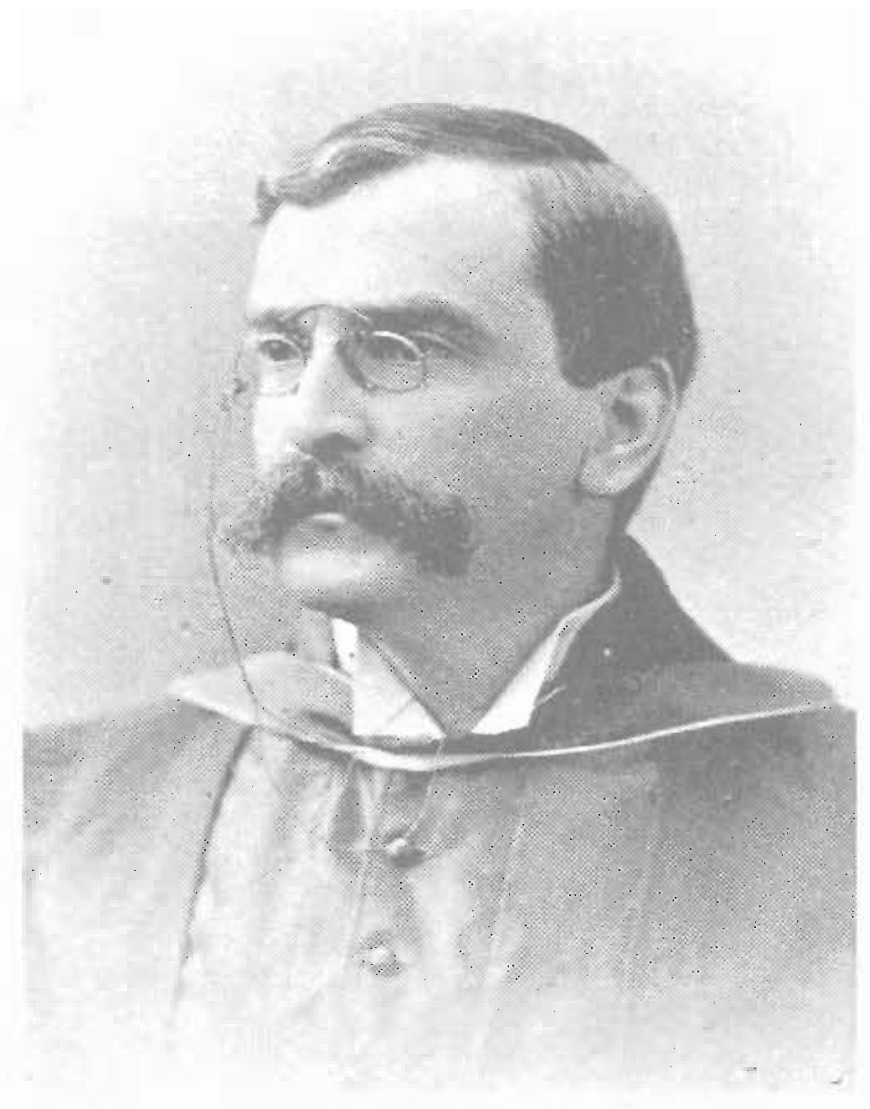

Figure 1. Sir William Peterson, Principal 1895-1919. McGill University Archives, Photographic Collection, PR 008099

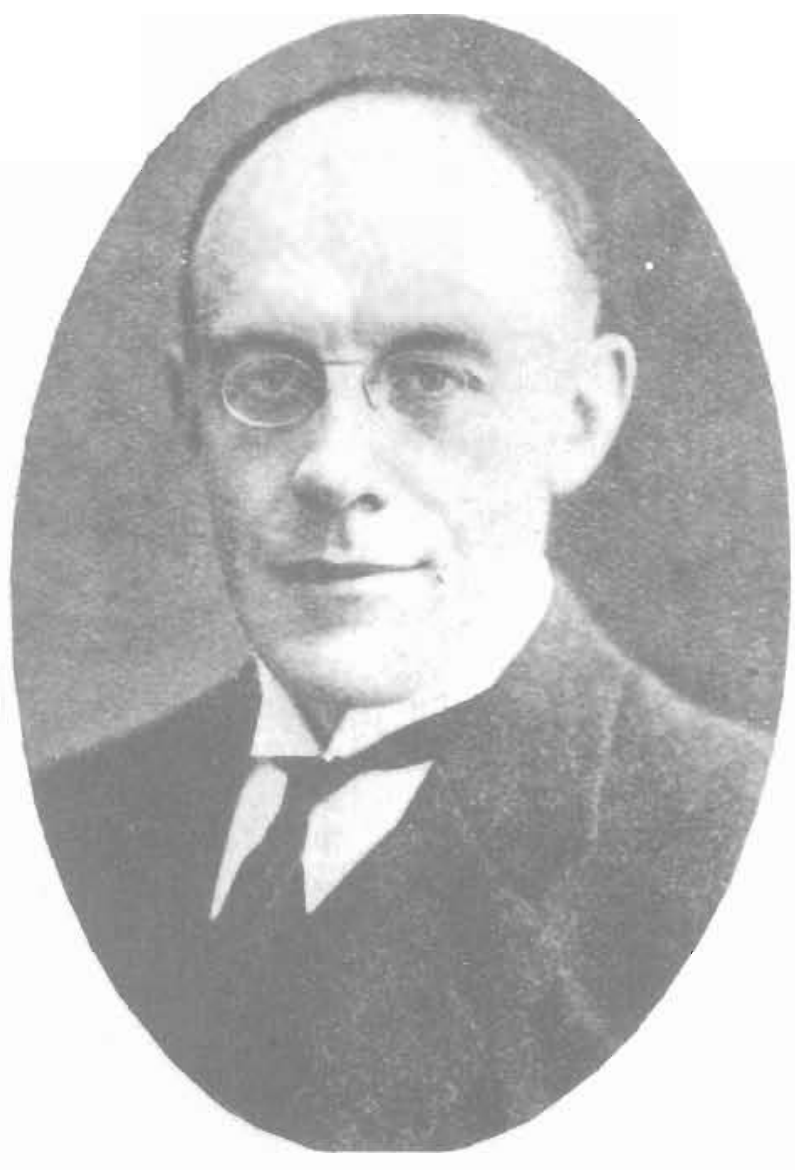

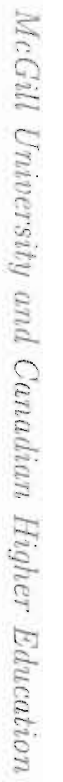

Figure 2. Sir Aukland Campbell Geddes, Principal 1919-1920. McGill University Archives, Photographic Collection. PU 010538. 


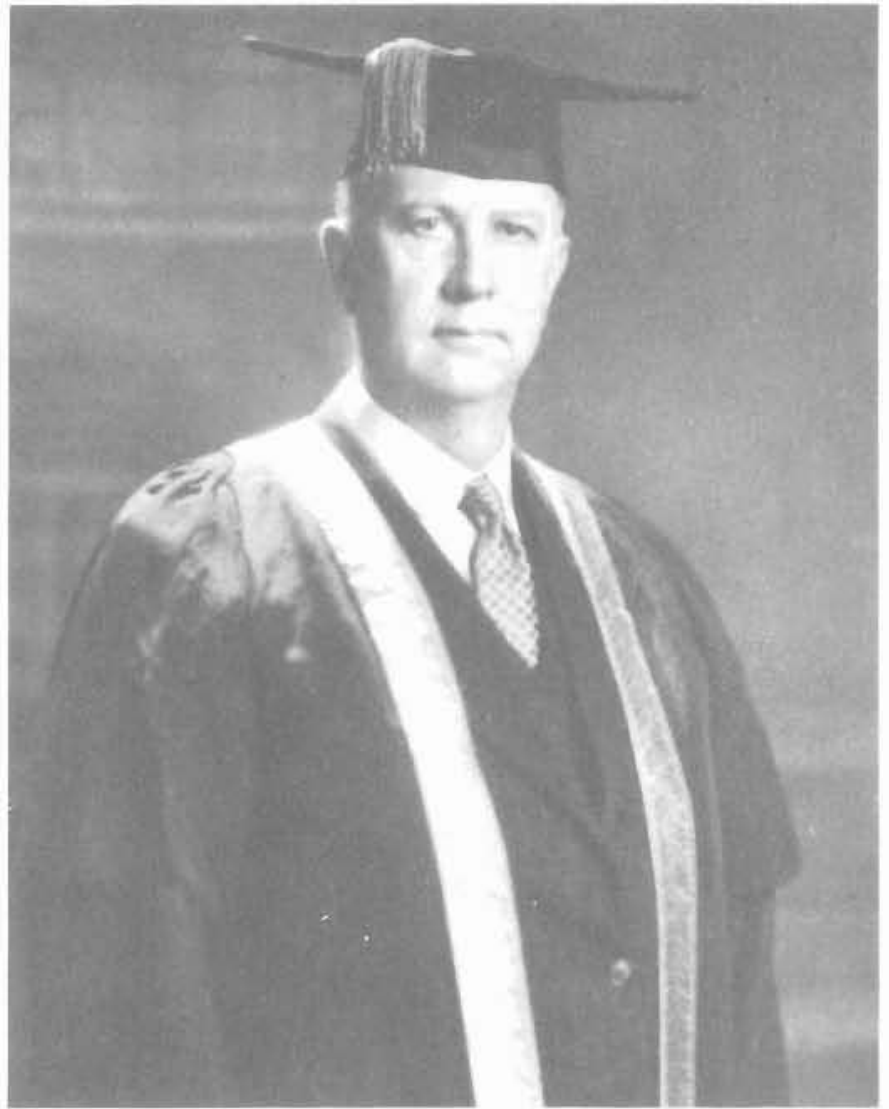

Figure 3. Sir Arthur Currie. Principal 19201933. McGill University Archives, Photographic Collection, PR 010537.

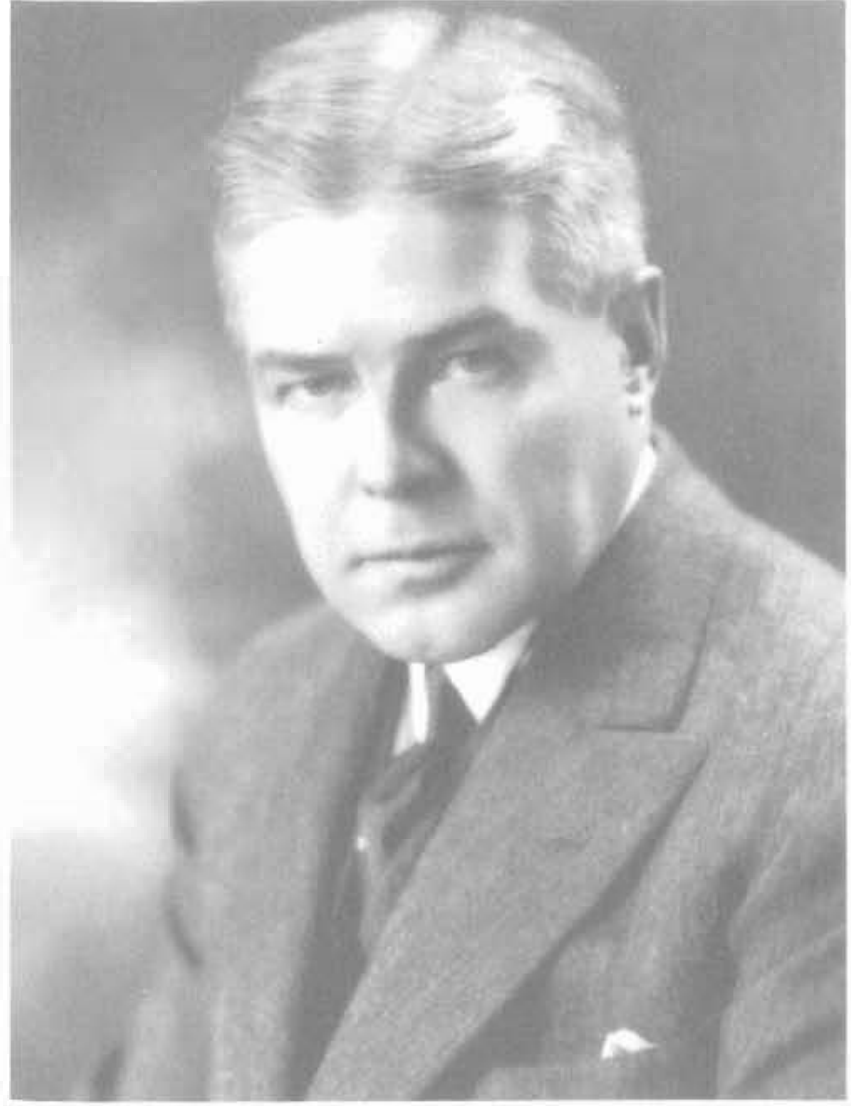

Figure 4. Chancellor Sir William Edward Beatty, de facto Principal 1933-1935. McGill University Archives, Photrophic Colection, PR 001861. 


\section{McGill University and Canadian Higher Education.}

the Canadian university in the early twentieth century.

On the general landscape of Canadian higher education, then, McGill was comfortably placed. But Canadian universities were not identical, and the differences among them, even if subtle, shaped their particular: auras. The following observations are my attempt to capture some unique aspects of McGill.

\section{Utilitarianism}

Perhaps the most distinctive feature of McGill was its history as a private university. For McGill's first 140 years, government funding was minuscule and unreliable. Beginning with the example of James McGili, prominent and frequently wealthy individuals sought to meet the educational needs of their class and community." Lean times notwithstanding, the years of. J.W. Dawson's principalship (1855-1893), witnessed significant donations from Peter Redpath, from the Moison family, and from financier Donald Smith (a.k.a. Lord Strathcona) whose contributions funded the Donalda program. for women's education and the construction of Royal Victoria College. Of course the major benefactor of McGill was the anti-smoking, tobacco manufacturer Willian. C. Macdona.ld, whose association with the university spanned the latter years of the Dawson and most of the William Peterson principalships. ${ }^{10}$ He provided unprecedented funding for science, engineering, an agricultural college, student residences, and chairs in history and moral philosophy, among other things. His contributions to McGill totalled some 14 million dollars, and he is described by one historian as the "greatest educational philanthropist of his day." II

These donations were augmented by the American Carnegie and Rockefeller foundations which, following World War I, subscribed one million dollars each to McGill, partly in recognition of the institution's "outstanding contribution" to the war. A fund-raising campaign in the early 1920s earned 5 million dollars and, between 1920 and 1933, McGill's annual income from all sources increased from $1 \mathrm{mil}$ lion to 2 million. dollars. ${ }^{12}$

Like other Canadian universities, McGill endured a. near fiscal drought during the 1930s, made more challenging by the continuing scarcity of public funding. In 1911, McGill had received all of $\$ 3000$ from the provincial government, in comparison to the $\$ 750,000$ provided to the University of Toronto by the Ontario government. ${ }^{13}$ In 1940, while Canadian universities as a whole received more than 40 per cent of their operating income from governments sources, McGill. secured. less than 10 per cent. ${ }^{14}$

The reliance of McGill on its sponsors and alumni. led to what; was surely one of the most unusual fund-raising campaigns in the university's - and. Canada's - history. In the 1930s McGill sought to raise money for the building of a gymnasium, no less, by distributing its own brand of cigarettes. An advertisement published in the McGill News noted. that of the five billion cigarettes sold in Canada in 1935, "McGill students and graduates smoked some six million of these. At fifty cents per thousand, that would mean $\$ 3000$ " to the gymnasium building fund. ${ }^{15}$

The especially heavy dependence of McGill on private sponsorship, combined with the accomplishments of its most famous researchers, account, in all likelihood, for the institution's particular academic: orientation and for its enviable reputation. Though. the arts were by no means absent at McGill, clearly the lion's share of funding from the 1890s to the 1930s went to medicine, other professions, and the applied sciences. William Osler, whose pioneering work in clinical medicine began at McGill, is described by the Canadian Encyclopedia as the "best known physician in the English speaking world" at the turn. of the century. ${ }^{16}$ Ernest Rutherford won. the Nobel Prize in 1908 for his work on radioactivity. Continuing in the superlative vein, the Canadian Encyclopedia found that he was "considered the greatest experimental physicist of the century."17 Wilder Penfield's decision in the early 1930s to establish the Rockefeller-funded Neurological Institute. at McGill, rather than in the U.S., was certainly $a_{\text {. }}$ coup for the university, as was the innovative work he conducted there. By way of interest, not to be outdone - never to be outdone - McGill political economist Stephen Leacock was described by his biographer in the Encyclopedia as "the Englishspealking world's best known humorist" from 1915 to $1925 .^{18}$

It was McGill's good fortune to come of age in an era when science and technology were in ascendance. The period in which the status of leading universities was linked exclusively to the reputations of their classically-trained clergymen or renowned. gentleman scholars had yielded to an age of utili- 


\section{McGill University and Canadian Higher Education}

tarianism. Institutions and academics perceived to be contributing to the improvement of material life were especially acclaimed. As Robin Harris notes, by 1920 McGill "was unquestionably Canada's most famous university," owing in part "to the enthusiasm of the many Americans who had been attracted to and graduated from its medical school."19

Indeed, when Abraham Flexner of the Carnegie Endowment for the Advancement of Teaching assessed. the quality of medical education in North American universities (1910), he could barely contain his enthusiasm for McGill. Despite being damaged by a recent fire, the university's laboratories were well funded and equipped, showing "what energy and intelligence can accomplish in the face of disaster. The anatomical and pathological museums are among the most famous on the continent. The school possesses an excellent library and all necessary teaching accessories." Clinical facilities "are excellent" and the school "enjoys a most favorable relation to two large hospitals." He had kind words too for the University of Toronto's medical school. By comparison the programs at Laval and Halifax, were considered feeble, and "Western University (London.) is as bad as anything to be found on this side of the line." 20

Principal William Peterson (1895-1919), himself a classicist, had hoped to improve the scope of humanistic studies at McGill, but as E.A. Collard observed, "the benefactors of McGill under his principalship had almost passed by the Faculty of Arts to concentrate their attention on the sciences and professions." 21 That the arts were not totally ignored was indicated by the presence of a number of respected scholars, including classics professor John Macnaughton, who worried publicly in 1904 about the utilitarian orientation of McGill at the expense of more traditional, scholarly values. "It will be black shame to us if it can be said fof an engineer] in his epitaph that he was born a man, went: through McGill University, and died a plumber." 22 In 1911, perhaps as much a statement of resignation as an academic prescription, Peterson wrote: "It is in great measure the pressing demands of industrial and commercial life that are giving our colleges so practical a turn at the present time." 23 Edward Beatty, a prominent businessman, Chancellor of McGill, and its de facto Principal for a two year period in the 1930s, was no major enthusiast of the abstract arts, or even the applied ones. He believed the university's most vital role was to develop the country's natural resources, by teaching "facts." He felt that there had been too much "wandering" in the universe of metaphysics. Students must be prepared for practical work. ${ }^{24}$ Reffecting its acadennic priorities between 1917 and 1939, McGill, along with the University of Toronto, received the overwhelming majority of Nationaj. Research Council post-graduate awards for studies in the sciences. ${ }^{25}$

During World. War II, Principal Cyril James supported a proposal to the National Conference of Canadian Universities that, if implemented, would have dramatically diminished the teaching of arts subjects in Canadian universities in favour of applied, war-related academic programs. ${ }^{26}$ After the war, James confirmed the legacy of McGill's priorities. He noted "the reputation of our greatest names were not forged in the slow studies of humanities and the social sciences, yet McGill, as the greatest privately endowed university, has a unique opportunity in these fields." He called upon McGill to give more attention to these underdeveloped areas of study in the future. ${ }^{27}$

\section{Imperialism}

A symbol of the growing links between education and industrial grawtb. McGill was also a beacon of Canadian nationalism and loyalism through the early twentieth century. Seeking a Principal who was "highly representative of the culture of imperiaJ. institutions," 28 Chancellor Donald Smith found those qualities in William Peterson, a. Scot schooled at Edinburgh and. Oxford, and a Principal of University College at Dundee. Peterson's imperial loyalties were unquestionable, so much so that he appeared to suffer from a permanent; case of homesickness. He was never entirely happy in. Canada, sent his sons to school in Britain, returned there every year himself, and spurned Canadian citzenship.

While Peterson's tentative commitment to Montreal and Canada were grounds for periodic reproval, his patriotic predelictions were shared by McGill spokespersons both before and since. The university recruited as Peterson's successor, Arthur Currie, the war time leader of the Canadian Corps in France. In Stanley Frost's words, "As long as Currie flourished as Principal, the passing of the imperial age and the birth of the new Canadianism were not easily discerned." He spoke frequently at Canadian 


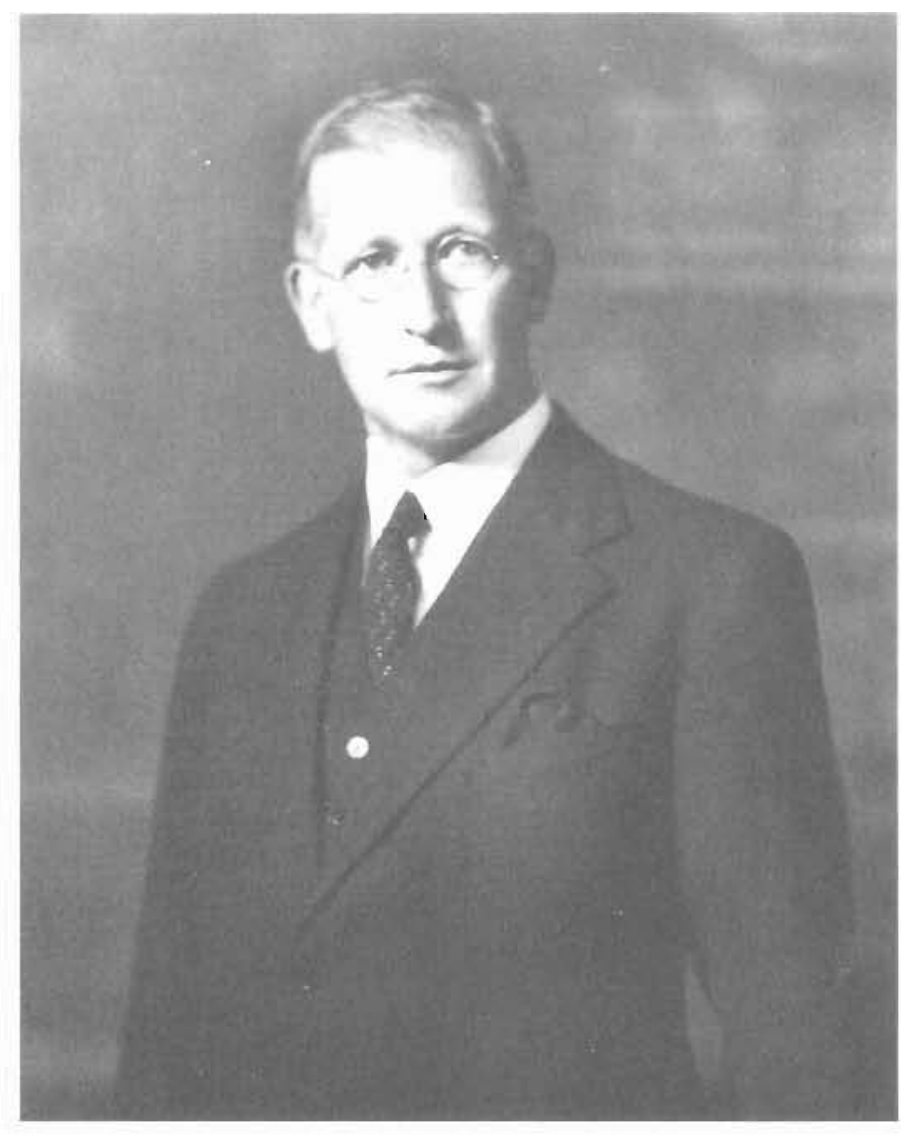

Figure 5. Arthur Eustace Morgan, Principa 1935-1937. McGili University Archives, Photographic Collection, PR 010532.

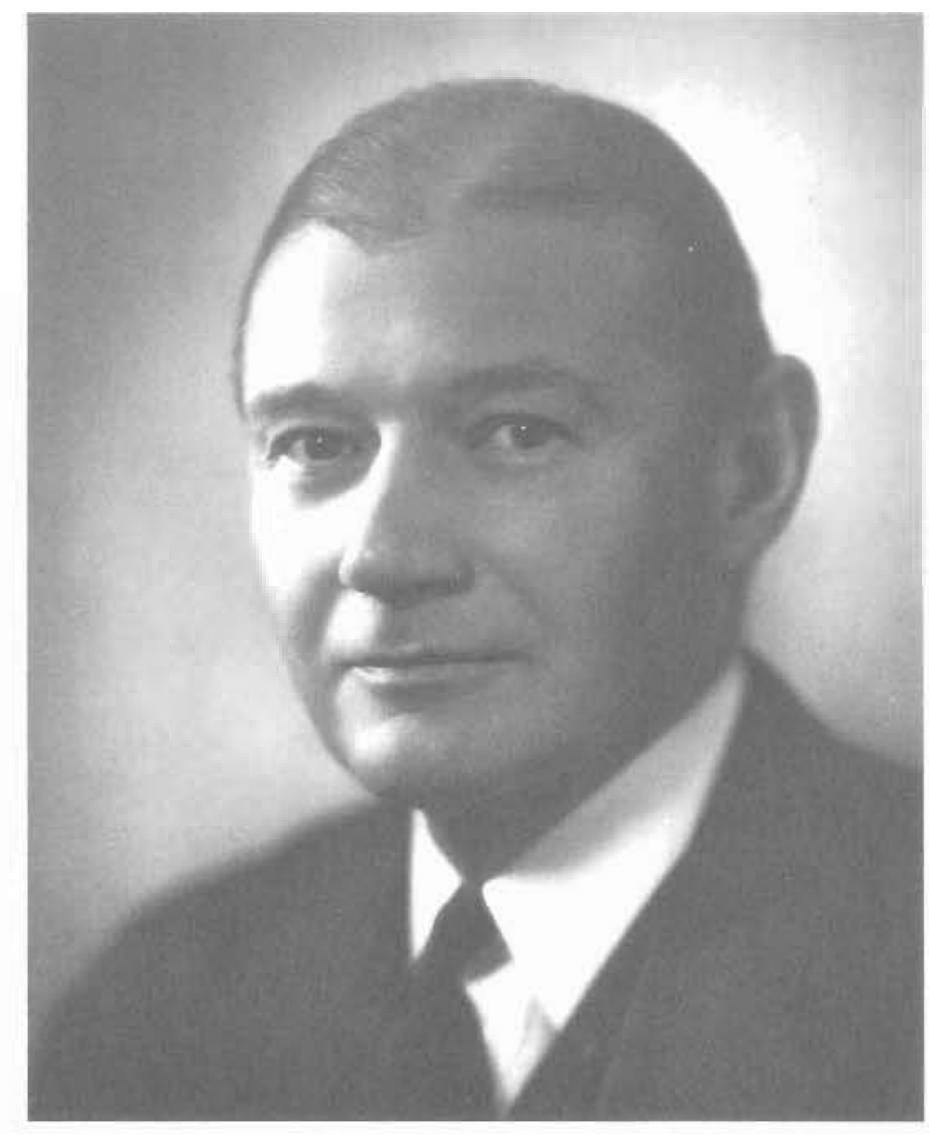

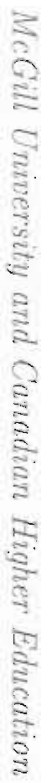

Figure 6. Lewis William Dougias, Principal 1937-1939. McGill University Archives, Photographic Collection, PU 010535. 
Club luncheons, legion rallies, and Armistice day celebrations - serving as a, kind of "father figure for all of anglophone Canada." 29

His successor was an actual Englishman, though, in the end, not of the variety that the McGill board had had in mind when they appointed him. Perceived as idiosyncratic and ideologically unreliable, Arthur E. Morgan, Principal from 1935 to 1937, had nevertheless been plucked from England's Hull College. McGill's perception of itself as an Anglosaxon bastion in a predominantly Frenchspeaking province undoubtedly reinforced its imperialistic orientation.

Other Canadian institutions could also be zealously protective of the imperial connection. In 1937, the University of Toronto reportedly cancelled its library subscription to the American magazine, the New Republic, because of an alleged slur on the King of England. It referred to his "dull and negative personality." 30 Still, it would appear that among universities, McGill's brand of loyalism was second to none in Canada. It was the first university to create a Canadian Officers' Training Corps in 1912; driven by the initiatives of Professor Henry Marshall. Tory, it played a critical role in the creation of the Khaki University for soldiers serving overseas during World War One; in Currie, it had chosen for its Principal a military commander, who was neither a clergyman nor an academic; and its contribution to the wars, in terms of personnel, casualties, research, and. veteran training were substantial, celebrated, and frequently recalled. In sum, its self-innage and identity appeared bound to its Anglo-Saxon mission and legacy, both within Quebec and the wider Englishspeaking community.

\section{Academic Freedom}

The concern for moral and intellectual order informed the purposes and regulations of Canadian universities in the first haif of the twentieth century. Indeed, University of Toronto historian George Wrong claimed in 1931 that "in the main the universities of the western world are strongholds of conservative thought and a steadying infuence on our society. This is not less true of McGill and Toronto than of Oxford and Cambridge."31 Academic freedom, the ability of professors to pursue scholarly work unimpeded by institutional or external restraints, existed in Canada, but as Wrong im- plied, on a qualified basis. This does not mean that universities were merely narrow-minded, intellectual penitentaries. An era which spawned scholars of the calibre of Harold Innis and Northrop Frye could hardly be entirely inhospitable to creativity. No one dared censor the irreverent Stephen Leacock; and his. colleague in the Department of Political Economy, J.C. Hemmeon, whose intellectual and ideological outlook: were liberal and arguably left of centre, enjoyed a long career at McGill. So did poet, Professor of Law, and social reformer Frank Scott, though not everyone at McGill was happy about this. ${ }^{32}$ Furthermore, the McGill Daily; whose rate of publication had no equal among campus newspapers in Canada, was an important outlet for student opinion, and successfully tested, at least on occasion, the boundaries of political propriety and sheer good taste.

But qualifications there were, and those who ran afoul of certain. codes of academic respectability, might well be at risk. Sir Edward Beatty wrote a lengthy, thoughtful and logically tenuous article on academic freedom, which on the one hand defended freedom of thought as "sacred," and on the other claimed that there were "limits within which these liberties may be exercised and that to exceed [them] is not only foolish but wrong." ${ }^{33}$ He claimed that the university must be accountable to its sponsors. If students were taught incorrectly, then "outside the university walls there may well be men competent to detect these errors. Every such case reflects discreditit on the university and shakes public confidence in it."34 At McGill and elsewhere, two types of sins could be committed by incautious professors and irrepressible students: embarrassing the univereity by speaking or behaving in ways which might rouse the ire of the institution's benefactors in government or the private sector; and vigorously promoting the cause of socialism in a. world wary of the prospects of insurgent Bolshevism. ${ }^{35}$ Historians have shown how government officials and the RCMP, in their surveillance and internment practices during the 1920 s and 30 s, at times naively. and at times intentionaliy, blurred the distinction between communists, socialists, outspoken liberals, and civil libertarians. ${ }^{36}$ Universities were touched by this censurious aura, and none more than McGill. It did not help that McGill came under the purview of the Padlock Law, that repressive, loosely worded provincial legislation, passed in 1937, which made it a criminal offence to circulate literature "tending to propagate communisin." 37 


\section{McGill University and Canadian Higher Education.}

Indeed, throughout the Depression, McGill University was frequently criticized by "concerned" citizens for harbouring, if not promoting, communist and/or socialist activism, and university officials were compelled to defend the institution's name. One such allegation came in 1931 from a Baron Eugene Fersen who wrote that "McGill University is contaminated with [Communist] ideas." In this instance, an RCMP Inspector wrote to his Commissioner that it "is ridiculous to think of the University as a hot-bed of Communism." 38 In the same year; Quebec Premier Taschereau advised Currie that, "Several good families of Quebec hesitate to send their boys to McGill on account of the spirit which seems to prevail among some of the professors. May I be permitted to express my surprise that in these hard times the great McGill University should lend a helping hand to socialism." 39 In 1936, the head of the Montreal Police Department's "Red Squad," which scrutinized student meetings, asserted, in response to public complaints, "there is no Red Menace of any description at McGill." At best some students were interested in Communism "in an intellectual way only and discuss it much the same as they would any topic of an educational nature." 40 When the war broke out, tolerance of dissident views among the police and the public diminished even further, and left-leaning organizations and individuals were especially vulnerable. In 1940, some 500 McGill students opposed to the reformist, and anticonscriptionist, Canadian Student Assembly, broke up one of its meetings, and manhandled some of its members. All of this was followed closely and reported on by RCMP agents who actually praised the "loyalty" of the student vigilantes. ${ }^{41}$

Another incident which pointed to the distinctiveness of McGill's social and political environment, occurred in 1936, and involved a confrontation between McGill and l'Université de Montréal students. Three delegates from the anti-fascist, Loyalist government of Spain, were invited to Montreal and, having been denied the right to speak at City Hall, were asked by the McGill Social Problems Club to lecture at the university. A group of students from l'Université de Montréal gathered outside the McGill Union, where the event was to occur, and threw rocks at those on the steps of the building. Later a mob of some 250, consisting mostly of Université de Montréal students, marched through the streets shouting anti-communist and anti-Jewish slogans. They proceeded to the Mount Royal Hotel, where the Spanish delegates were staying and, apparently unprovoked, assaulted a McGill professor. The turbulent weekend ended with a massive anticommunist, pro-Catholic demonstration at Champs de Mars.

Termed a "riot" by the press, these confrontations seemed to symbolize deep political cleavages between students from the two universities, though the majority from both campuses were uninvolved in the events. In the heat of the moment, rhetoric was rife; subsequently, attempts were made by the student councils of both universities to "patch up their differences" by publicly shaking hands and symbolically "burying the berets." To encourage better communication, the editors of the McGill Daily and the Quartier Latin agreed to write columns in each other's papers. This - admittedly extreme - incident signified both the different worlds which French and English Canadian youth occupied, and the efforts by student leaders to forge, in moments of crisis, political accomodation. Such challenges, which faced all of Canada, were of course heightened in Montreal.

French-English relations aside, the activities of certain McGill students were of special interest to the RCMP in this period. The speeches and travels of David Lewis were closely monitored, as were those of the group he headed, the McGill Labour Club. ${ }^{42}$ Indeed, because of their irreverent and critical content, the Alarm Clock, a publication of the McGill Labour Club and the Black Sheep, a magazine which especially angered McGill benefactor J.W. McConnell, and according to Principal Currie, "was a criticism of everything?" were banned from the campus by university officials in $1933 .{ }^{43}$

Sharing a commitment to keeping the campus politcally quiescent, particularly in light of public complaints (however unfounded), Currie and the RCMP had carried on a regular correspondence on the activities of McGill members. As the Commissioner of the RCMP told Currie in 1933, "I am quite satisfied that you are doing all that is possible at McGill to assist in the control of Communism." $44 \mathrm{He}$ looked for similar cooperation at other universities. "It would be a big help if the University Authorities would control the public actions of some of their professors..."

Two of the professors who most worried McGill authorities and its external scrutineers were Eugene Forsey, a lecturer in political economy, and an important figure in the non-communist League for 


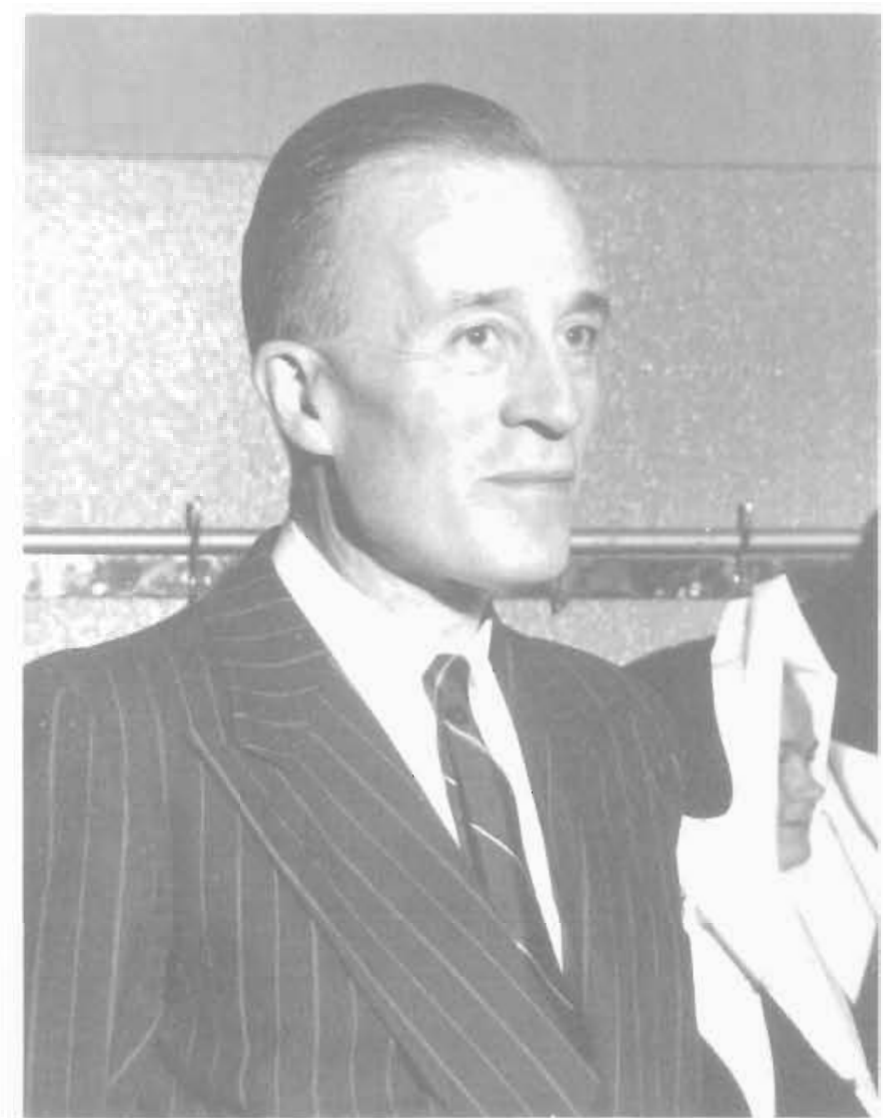

Figure 7. Frank Cyril James. Principal 19391962. McGill University Archives, Photographic Collection, PR 026844.

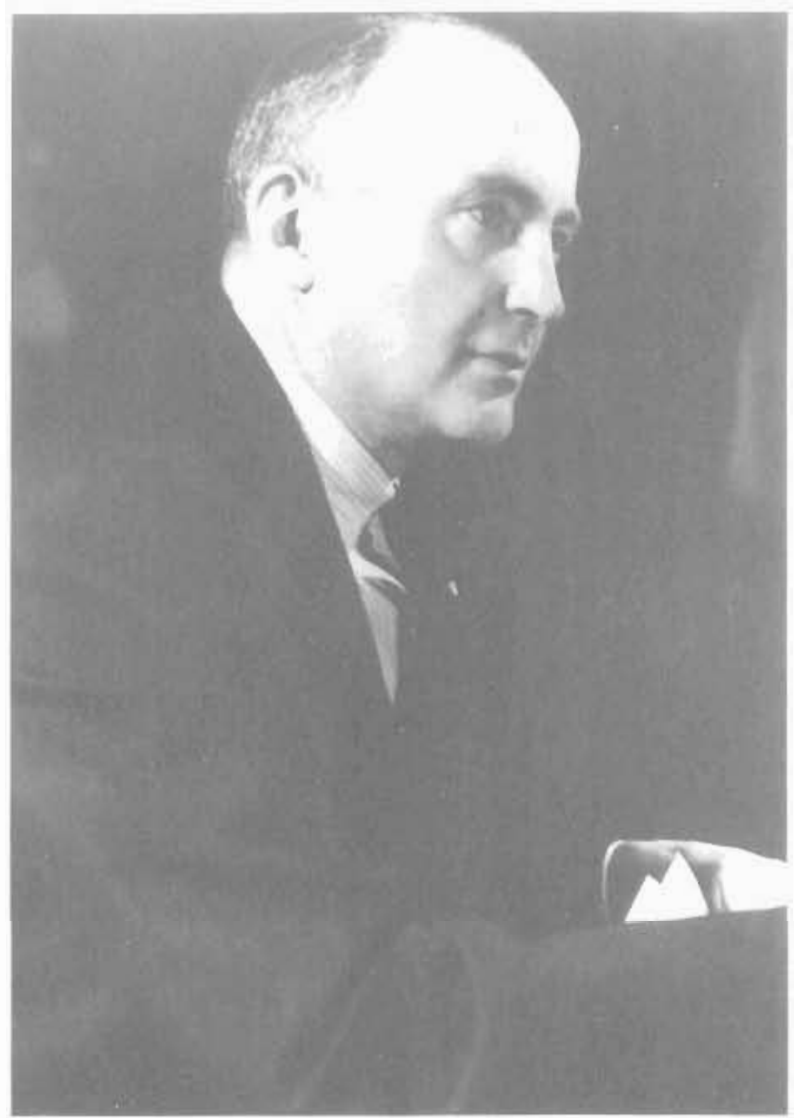

Figure 8. Harold Rocke Robertson, Principal 1962-1970. McGill University Archives, Photographic Collection, PR 023259 
Social Reconstruction, and social scientist Leonard Marsh. Forsey, an outspoken socialist, angered Currie, who believed he roused "a good deal of criticism upon the University for the things he says in his public addresses." 46 Currie told Premier Taschereau. that he had been searching for ways to sack Forsey without provoking a "cause celèbre." He did not want to leave the impression the McGill did not tolerate "freedom of speech." ${ }^{47}$ In response to a complaint about Forsey from A.B. Purvis, President of Canadian Industries and a McGill Board member, Currie wrote "Had I dismissed him, it would have been held to be the arbitrary act of the Principal, whom too many already look upon as the mouthpiece of St. James Street." 48 Under Currie, Forsey kept his job.

Marsh headed the Social Science Research Project, which was funded in 1931 by a Rockefeiler grant, and in the utilitarian spirit of McGill, had originally been designed to explore the relationship between industry and community life in Montreal. Marsh, a Fabian socialist, believed he was well within the project's terms of reference by focusing on the problems of unemployment and poverty which gripped Montreal during the depression. His critics, including Sir Edward Beatty, considered this work too critical of capitalism, and the pressure to curb the project intensified. ${ }^{49}$ During the brief tenure of Principal Lewis Douglas (1937-39), the grandson of a McGill benefactor, an industrialist and former budget chief in the Roosevelt cabinet, the university's appointment rules were rewritten, or at least reinterpreter, in a way that finally allowed for the severing from the university faculty of both Forsey and Marsh. ${ }^{50}$ They both went on to distinguished careers in arademic life and public service.

Was McGill a less tolerant university than others? The views of its leaders in fact were not dramatically different from those of university presidents elsewhere. No institution permitted unqualified freedom of expression; none was consistently authoritarian, though my impression is that universities in western Canada were somewhat less vexed by irreverent student behaviour than those in the east. All worried about leftist faculty and students, far more so, incidentally, than they did about those on the right, including the far right. In the late 1930s, while fascist Adrien Arcand was permitted to speak at $\mathrm{McGill,}$ communist Tim Buck was not. The controversial speeches of Scott and Forsey elicited police attention, but when McGill chemist R.W. Steacie re turned from a trip to Germany and spoke favourably of Hitler in 1935, no complaints were registered 51 The political partisanship of socialist professors was invariably questioned; of conservatives and liberals, virtually never. ${ }^{52}$

In the concern they showed for dissenting faculty and provocative students, the comparative experiences of McGill and the University of Toronto are striking. A report in November 1932 that McGill students had imbibed on a tour of Molson's Brewery led to the dismissal of the managing board of the McGill Daily. At Toronto in 1929, the editor of the Varsity lost his job for acknowledging that "petting" was a common practice among the university's youth ${ }^{53}$

The furor caused by Toronto historian Frank Underhill, who could not stay out of trouble, mirrored the controversies roused at MicGill by the presence of Forsey, Marsh and Frank Scott. Both universities were surrounded and sustained by relatively conservative communities, an aura which undoubtedly affected campis culture. Underhill, however, never lost his job. But two of McGill's heretics did. The university seemed especially sensitive to the views of its benefactors and sponsors. From 1935-39, the governors dug into their own pockets to keep the undversity afioat. As Staniey Frost notes, "Seeing that they were carrying the university financially, it seemed to the governors only just that some of its professors should be presenting the capitalist view of society as vigorously as the socialists were advocating theirs." 54

As we have seen, such private slipport built the university and saw it through hard times, but it may also have made McGill less receptive to minority opinion than was the case at other academic institutions. If the piper did not consistently call the tune, his bellows could scarcely be ignored.

\section{Anti-3emitisin}

McGill was sensitive 10 community opinion in another way that differed not in kind but in degree from its sister universities. Overwhelmingly white, Anglo Celtic, Protestant, and to a lesser degree Catholic, English Canadian universities were determined to preserve their cultural mix. Eike those administering immıgration policy, university officials did this not by banning minority groups but by rigidly controlling thesi numbers. By virtue of 
the significant proportion of Jewish students who sought admission, they were perceived as a particular threat to the composition of the campuses, and extraordinary actions were taken, similar to those in the United States, to limit, and in some cases reduce, their presence.

McGill led the way on this front. In 1924-25, Jews constituted 24 per cent of the arts faculty, 15 per cent of medicine and 40 per cent of law. A major force behind the implementation of a new set of admission policies was Ira. MacKay, Dean of the Faculty of Arts, a man who had once berated David Lewis for his "backward race" and national origin. On another occasion, he wrote, "The simple obvious truth is that the Jewish people are of no use to us in this country...As a race of men their traditions and practices do not fit in with a high civilisation in a very new country." In 1926, he called for the university to limit the proportion of Jewish students in arts to 20 per cent, and in 1934 to reject appeals for the admission to the faculty "of displaced German scholars," many of whom were Jewish refugees. "There are very few questions upon which I am defiant," he stressed to Currie, "but this is one of them." "55

The course followed by the university was, if anything, more restrictive then that recommended by MacKay. While he had suggested that Jewish highschool graduates be required to obtain averages of 70 per cent to çalify for admission, in fact, at the end of the 1930s they needed 75 per cent. By contrast, gentile students achieving 60 per cent were allowed to enrol. Under the impact of such policies, applied with equal vigour in the professional schools, by 1939 Jewish representation had declined to 12 per cent in arts, less than 13 per cent in medicine and 15 per cent in law. ${ }^{56}$

Admission quotas were also applied at the Cniversity of Manitoba, and the University of Alberta. normally refused to enrol Jews from outside the province in the medical school. In 1934, when a Jewish medical graduate was accepted as an intern in Montreal's Hôpital Notre Dame, French-Canadian interns from the University of Montreal walked off the job in protest. In British Columbia, Japanese Canadian students endured the brunt of discriminatory policies. ${ }^{57}$ Throughout the country, including Montreal and Toronto, blacks were banned from clinical practice in most hospitals, and generally prevented from enrolling in university medical programs. Facing what it believed to be an especially menacing challenge, McGill took exceptional actions to stem the ethnic, non-Christian incursion on campus. Happily, these polices at McGill and elsewhere were abandoned in the post-war era, as more liberal social values and enrolment practices finally took root.

\section{The Experience of Women}

For a time in its history, McGill also sought to restrict access of women to its classrooms. J.W. Dawson, Principal in the last half of the 19th century, opposed co-education, and under the terms of a major donation from Donald Smith, McGill adopted a strategy, unique for Canada, of educating women and men in separate classes. The will and resources of the benefactor notwithstanding, segregated teaching proved to be both unacceptable and unaffordable, and co-education gradually became the norm. By 1916 "it was no longer possible for a Royal Victoria College student to complete even her first two years entirely in separate classes." 518

Through the early twentieth century, the experience of McGill women largely paralleled that at other universities, in that they occupied a "separate sphere" both academically and socially. In 1912, McGill did appoint Canada's first female full professor, Carrie Derick, though as Margarei Gillett notes, this did not exactly augui an egalitarian revolution. 59 Women obtained admission only in 1918 to the otherwise innovative Faculty of Medicine. Throughout the country, by 1940 , women dominated the professions of household science, librarianship, nursing, social service, and elementary school teaching. In the professions with higher status, they were practically an invisible minority, comprising 2 per cent of lawyers, 3 per cent of doctors, and less than i per cent of engineers. ${ }^{60}$ Their cause was scarcely aided by perceptions such as those of McGill psychology professor William Tait, who concluded in 1930 that, on the basis of "scientific" evidence, women had less capacity for abstract thought than men owing to the smaller size of their "frontal lobes." Many male students were evidently persuaded by these views. According to a 1939 editorial in the McGill Daily, while men were suited to the economic function of production, "women's qualifications run in the sphere of consumption," supposedly reinforcing their natural connection to the household. ${ }^{61}$

Between the wars, McGill women were barred from running for the Student Council, joining the 
Political Economy Club, or participating in the Mock Parliarent, and rarely did they hold editorial positions on the McGill Daily. As was true at other campuses, women in residence, unlike men, were governed by a panoply of paternalistic curfew and visitation regulations. Female faculty were not, allowed to eat at the "faculty" club. Professor of Library Science Effie Astbury noted that, as late as 1979 , the year of her retirement, it was still customary for women to be addressed as Miss or possibly Ms, but not "Professor."

Women were aware of this differential treatment, and periodically challenged it, but like their fellow students elsewhere, they tended to recall their university years with enthusiasm and affection. When Shirley Goldenberg was admitted as a mature student to the graduate program in the late 1950s, a university official inquired as to the occupation of her husband - a prominent lawyer - and expressed relief that she was unlikely to threaten his status and position. Such indignities aside, she recalled that "My undergraduate years [a decade earlier] could not have been happier." 6.3 Margaret Grant, who graduated in 1933, remembered the sport that women had defying residence rules, and spoke fondly of the sense of community that thrived among her classmates. ${ }^{64}$ Author Constance Beresford-Howe, who would eventually teach st McGill, was inspired by her fourth year instructor, Gertrude Mason. "She breathed such passionate life into Anglo-Saxon literature, Chaucer and Jacobean dramatists, that her students couldn't easily avoid becoming infatuated with them." 65 in this era, women derived from their universities not equality of treatment, but the possibility of camaraderie that made campus life rewarding, and, given the intellectual and social skills they acquired, a margin of independence that would ultimately serve them well in the workplace, at home, and in their communities. ${ }^{.6}$

\section{Post-War Challenges}

As Canadian universities entered an era of unprecedented expansion in the late $1950 \mathrm{~s}$ and $60 \mathrm{~s}$, the characteristics which had distinguished them, to some degree, diminished. Collectively, they were pressured to provide adequate space for a generation of post-war baby boomers; consequently enrolments ballooned. They were perceived, more than ever, to be instruments of economic utility and consumed unprecedented amounts of public funding, which in McGill's case began in earnest in 1963. All universi- ties were reformed in the wake of the student movement of the $1960 \mathrm{~s}$. The institutions virtually abandoned the goal of attempting te cultivate character and regulate social lives, and students, including women, won more autonomy. Universities developed academic programs that offered more breadth and choice, and university faculty gained a greater role in institutional decision making. ${ }^{67}$ At McGill the fields of physics and chemistry remained major priorities, but the arts too, responding to contemporary student interest, achieved a far higher status than in earlier eras. Relations with the Quebec government ranged from tense to accomodating, amid a political atmosphere that was frequently charged and uncertain, perhaps never more than at present. ${ }^{68}$

Today, all universities are consumed by the challenge of how to maintain enrolment, quality and morale in the face of public funding rollbacks. A clue to McGill's future strategy can be found in a statement called "Towards a New McGill," delivered by Principal Bernard Shapiro on October 1, 1995. As he saw it, McGill's financial difficulties were compounded by the shrinkage of the Anglophone population of Montreal, and by the political instability generated by the sovereigntist movement. But the institution's assets, literally, were significant. They included the loyalty and generosity of its alumni, which "provide a strong basis for private funding," and a projected $\$ 500$ million endowment trust, enhanced by the most recent fund-raising campaign. McGill had "established strengths in research" and a "reputation for excellence...particularly in the areas of privately funded teaching programmes," which should facilitate new partnerships with "other universities or with industry." The Principal's downto-earth proposal anticipated a smaller unversity, dependent again upon its own resources, carefully selecting its priorities, as it secures an appropriate niche in the academic and globai marketplaces. In this vision of McGill's future, there are echoes of its past. ${ }^{69}$

\section{Conclusion}

The writing of institutional history is a valuable, and frequently essential, precondition for mapping a country's educational experience. A fuller picture of the cultural landscape, however, requires that one university's story be set in a wider analytical context. This paper has sought to explore selected aspects of McGill's history against the background of Canadian university development, focusing primar- 
ily on the first half of the twentieth century.

Devoted, like other universities, to the task of preparing a select, group of young people for middle class occupations, McGill was especially dependent on the material and moral support of its anglophone sponsors. While turning inward for the resources that sustained it, it cultivated an important educational role within a wider English-speaking universe, where it was best known for its scientific endeavours. Given its fiscal vulnerability, and the conservative inclinations of the community it served, McGill ws particularly sensitive to episodes that might sully its image. Iconoclastic professors and students were allowed autonomy - within limits. As the university's academic spirit became more liberal, and its admission policy more inclusive, its record of accomplish-ment sustained its status and reputation. ${ }^{70}$ McGill's apparent response to current challenges is to narrow its academic focus. It remains to be seen whether this strategy will help maintain or diminish its elevated place on the Canadian educational landscape.

\section{NOTES}

1. This is a revised version of an. invited address delivered to the James McGill Society of McGill University on April 29, 1996. The presentation was cosponsored by the McGill Institute for the Study of Canada. I would like to thank Professor Michiel Horn of Glendon College, York University, for permission to cite material from his forthcoming book on the history of academic freedom in Canada.

2. Michael L. Skolnik and Glen A. Jones, "A. Comparative Analysis of Arrangements of State Coordination of Higher Education in Canada," Journal of Higher Education 63, 2(Mar./Apr. 1992): 121-1.42; Henry Srebnik, "Football, Frats, and Fun vs Commuters, Cold, and Carping: The Social and Psychological Context of Higher Education in Canada and the United States," in Canada and the United States: Differences that Count, ed. David. Thomas (Toronto: Broadview Press, 1993), 380407; Paul Axelrod, "Higher Education in Canada and the United States: Exploring the Roots of Difference," Historical Studies in Education 7, 2(1995): 141-175. A most significant departure from the institutionalist approach is A.B. McKillop, Matters of Mind: the University in Ontario, 1791-1951 (Toronto: University of Toronto Press, 1994).

3. Chad Gaffield, Lynne Marks, and Susan.
Laskin, "Student Populations and Graduate Careers, 1895-1900," pp. 3-25; and Judith Fingard, "College, Career, and Community: Dalhousie Coeds, 1881-1921," pp. 26-50, in Youth, University and Canadian Society: Essays in the Social History of Higher Education, ed. Paul Axelrod and John G. Reid (Montreal: McGill-Queen's University Press, 1989).

4. Stanley Brice Frost, McGill University for the Advancement of Learning, Volume II, 1895-1971 (Montreal: McGill-Queen's University Press, 1984), 폰. 125 .

5. Paul Axelrod, Making a Middle Class: Student Life in English Canada during the Thirties (Montreal: McGill-Queen's University Press, 1990), p. 22 and passim.

6. Cyrus MacMillan, "The University and the Freshman," The University Magazine 10, no. 2 (April 1911): 210.

7. Cited in Hugh M. Urquart, Arthur Currie: The Biography of a, Great Canadian (Toronto: J.M. Dent and Sons Canada Ltd., 1950), 348.

8. Axelrod, Making a Middle Class, pp. 92-93, 118-121.

9. Stanley Frost describes the founders of McGill as "Montreal businessmen who needed education for their children and who were prepared to create and sustain the institution. which could supply that need." Stanley Brice Frost, "Who Runs This Place Anyway?" in Graduates' Society of McGiil University, McGill: A Celebration (Montreal: McGillQueen's University Press, 1991), p. 64.

10. For a biographical portrait, see Stanley Frost and Robert Michel, "Sir William Macdonald: An Unfinished Portrait," Fontanus, Vol. VIII, 1995: 5979.

11. Robert Stamp, "Evolving Patterns of Education: English-Canada from the 1870 s to 1914, , in Canadian Education: A History, eds. Robert Stamp, J.D. Wilson, W.P. Audet (Scarborough, Ont.: Prentice-Hall, 1970), p. 332 and Frost, McGill University: For the Advancement of Learning, passim. See also Yves Gingras "The Institutionalization of Scientific Research in Canadian Universities: The Case of Physics," Canadian Historical Review LXVII (no. 2), 1986: 185-6, for a discussion of the importance of Macdonald's contributions to physics at McGill. 
12. Robin S. Harris, A. History of Higher Education in Canada, 1663-1960 (Toronto: University of Toronto Press, 19'76), p. 357.

13. Frost, McGill University: For the Advancement of Learning, p. 86.

14. McGill University, Annual Report, 1940-1941, p. 107; Statistics Canada, Historical Compendium of Education Statistics from Confederation to 1975 (Ottawa: Statistics Canada, 1978), p. 250.

15. McGill News 17, no. 4, 1936 (McGill University Archives)

16. Charles G. Roland, "William Osler," The Canadian Encyclopedia (Edmonton: Hurtig, Press, 1985), 1340-1.

17. Yves Gingras, "Ernest Rutherford," Itid, $1610-11$.

18. Gerald Lynch, "Stephen Leacock," Jbid, p. $989-90$.

19. Harris, A History of Higher Educotion in Canada, 1663-1976 pp. 218, 219.

20. Abraham Flexner, Medical Education the United States and Canada: A Report to the Carnegie. Foundation for the Advancement of Teaching (New York: Anro Press and the New York Times, 1972 , originally published 1910), pp. 324, 325 .

21. E.A. Collard, "Sir William Peterson's Principalship, 1895-1919," in McGill: The Story of a University, ed. Hugh MacLennan (London: George Allen and Unwin, 1969), p. 84.

22. Cited in Frost, McGill University: For the Advancement of Learning, p. 54.

23. William Peterson, Canadian Eissays and Addresses (London: Longman's Green and Co., 1915), p. 318.

24. Cited in Marlene Shore, The Science of Social Redemption: McGill, The Chicago School, and the Origins of Social Research in Canada (Toronto: University of Toronto Press, 1987), p. 22.

25. McGill received 325, Toronto, 233 and all other Canadian universities combined, 153. See Yves Gingras, "Financial Support for Post-graduate Students and the Development of Scientific Research in Canada," in Youth, University ana Canadian Society: Essays in the Social History of Higher Education, p. 312 .

26. The best account of this episode is in Frederick G. Gibson, To Serve and Yet Be Free: Queen's Uni- versity, Volume II, 1917-1961, (Montreal: McGillQueen's University Press, 1983), pp. 208-14.

27. Cited in R.C. Fetherstonaugh, McGill University at War (Montreal: McGill University, 1947), p. 362.

28. Frost, McGill University: For the Advancement of Learning, p. 6.

29. Frost, McGill University: For the Advancement of Learning, p. 131.

30. Axelrod, Making a Middle Class, p. 138.

31. Cited in Michiel Horn, The League for Social Reconstruction (Toronto: University of Toronto Press, 1980), p. 182.

32. Michiel Horn, "Academic Freedom and the Canadian Professor," CAUT Bulletin, December, 1982, pp. 19-22. Frank Scott recalled "numerous instances of being asked to tone down his statements about public affairs or to reduce his involvement in politics...He was kept from the deanship of the Faculty of Law long after it should have come to him according to the practices of the Faculty and the University."

33. Sir Edward Beatty, "Freedom and the University, Queen's Quarterly XLIV no. 4 (1937): 463-71. Quote from p. 467.

34. Ibid, p. 468.

35. A detailed discussion of conflicts, not only between students and university authorities, but among students themselves, can be found in Charles Levi, " 'Decided Action Has Been. Taken': Student Government, Student Activism, and. University Administration of the University of Toronto and McGill University; 1930-1950," unpublished graduate research paper, York University, 1993.

36. See Paul Axelrod, "Spying on the Young in Depression and War: Students, Youth Groups and the RCMP', 1935-42 Labour/Le Travait 35 (Spring 1995): 43-63; S.R. Hewitt, "Spying 101: The RCMP's Secret Activities at the University of Saskatchewan, 1920-1971," Siaskatchewan History 42, no. 2 (Fall 1995): 20-31; Reg Whitaker, "Official Repression of Communism During World War II," La,bour/Le Travail 17 (Spring 1986): 135-167.

37. John Thompson and Allen Seager, Canada, 1922-1939: Decades of Discord (Toronto: McClelland and Stewart, 1987), p. 285.

38. Montreal Gazette, 1 May 1931; J.W. Phillips 
to Commissioner Cortlandt Starnes, 9 May 1931; Cortlandt Starnes to Arthur Currie, 13 May 1931, Canadian Security Intelligence Service (CSIS) Files, in possession of the author following application through the Access of Information Act.

39. Michiel Horn, "Socialism at McGill," unpublished chapter from his forthcoming book on the history of academic freedom in Canada.

40. Montreal Standard, 18 April 1936, clipping in CSIS Files.

41. Paul Axelrod, "Spying on the Young in Depression and War..." p. 52.

42. Report on Lewis speech followed his trip to Russia, 16 May 1931, and on a speech by Forsey, 14 Jan. 1932 (CSIS Files). See also Michiel Horn, The League for Social Reconstmuction: Intellectual Origins of the Democratic Left in Canada, 19301942 (Toronto 1980).

43. Arthur Currie to J.H.B. MacBrien, Commissioner of the RCMP, 11 Feb. 1933 (CSIS Files).

44. MacBrien to Currie, 13 Feb. 1933.

45. Ibid.

46. Horn, "Socialism at McGill", p. 4.

47. Horn, p. 9.

48. Currie to Purvis, Oct. 23, 1933, RG2 C42, F301 Principal's Papers, File: Communism \& Socialism: Forsey, Gordon and Scott, and the CCF, McGill University Archives.

49. Horn, p. 15.

50. Marlene Shore, The Science of Social Redemption, p. 21; Horn, "Socialism at McGill", pp. 26-31.

51. Horn, p. 18-19.

52. This is confirmed in the letter from Currie to Purvis cited above (Note 48). He lists all of the members of the Economics department, and describes their political affiliations. All except one were described as being "Liberal" or "Conservative" and thus no threat to the university.

53. Axelrod, Making a Middle Class, p. 114.

54. Frost, McGill University, For the Advancement of Learning, p. 196.

55. David Lewis, The Good Fight: Political Memoirs, 1909-1958 (Toronto: MacMillan of Canada, 1981), p. 23; Ira A. McKay to Arthur Currie, April 23, 1926, Jewish Students at McGill, RG2 C48, Principal's Papers, MUA; See also Axelrod, Making a
Middle Class, pp. 32-3.

56. Stanley Frost and Sheila Rosenberg, "The McGill Student Body: Past and Future Enrolment," McGill Journal of Education 15, no. 1 (Winter 1980): 41-3. See also Axelrod, Making a Middle Class, pp. 32-4.

57. David Rome, Clouds in the Thirties: On AntiSemitism in Canada, 1929-1939 (Montreal: National Archives, Canadian Jewish Congress, 1979), pp. 36-54; Elaine Bernard, "A University at War: Japanese Canadians at UBC During World War II," BC Studies, no. 35 (Autumn 1977): 36-55.

58. Paula J.S. LaPierre, "The First Generation: The Experience of Women University Students in Central Canada," Ph.D. thesis, University of Toronto, 1992, p. 148.

59. Margaret Gillett, We Walked Very Warily: A History of Women at McGill (Montreal: Eden Press Women's Publications, 1981), pp. 4-5.

60. See Making a Middle Class, pp. 153-4.

61. William D. Tait, "Some Feminisms," Dalhousie Review 10 (1930-32): 52-3; McGill Daily, 26 Oct. 1939.

62. For this and other recollections, see Margaret Gillett and Kay Sibbald, eds., A Fair Shake: Autobiographical Essays by McGill Women (Montreal: Eden Press, 1984), p. 263.

63. Ibid, p. 252.

64. Ibid, p. 29.

65. Ibid, p. 34.

66. Axelrod, Making a Middle Class, pp. 35-7, 116-122.

67. On the post-war period, see Edward Sheffield, "The Post-War Surge in Post-Secondary Education: 1945-69," in Wilson, Stamp, Audet, eds., Canadian Education: A History, pp. 416-443; Paul Axelrod, Scholars and Dollars: Politics, Economics and the Universities of Ontario, 1945-1980 (Toronto: University of Toronto Press, 1982); David M. Cameron, More than an Academic Question: Universities, Government, and Public Policy in Canada (Halifax: The Institute for Research on Public Policy, 1991).

68. Frost, McGill University: For the Advancement of Learning, Parts II and III.

69. Bernard Shapiro, "Towards a New McGill," Statement to Senate and Board of Governors of McGill University, October 1, 1995, released on In- 
McGill University and Canadian Higher Education

ternet, Jan. 15, 1996.

70. One controversial indication of this is McGill's consistently high ranking in Maclean's annual survey of Canadian universities. 


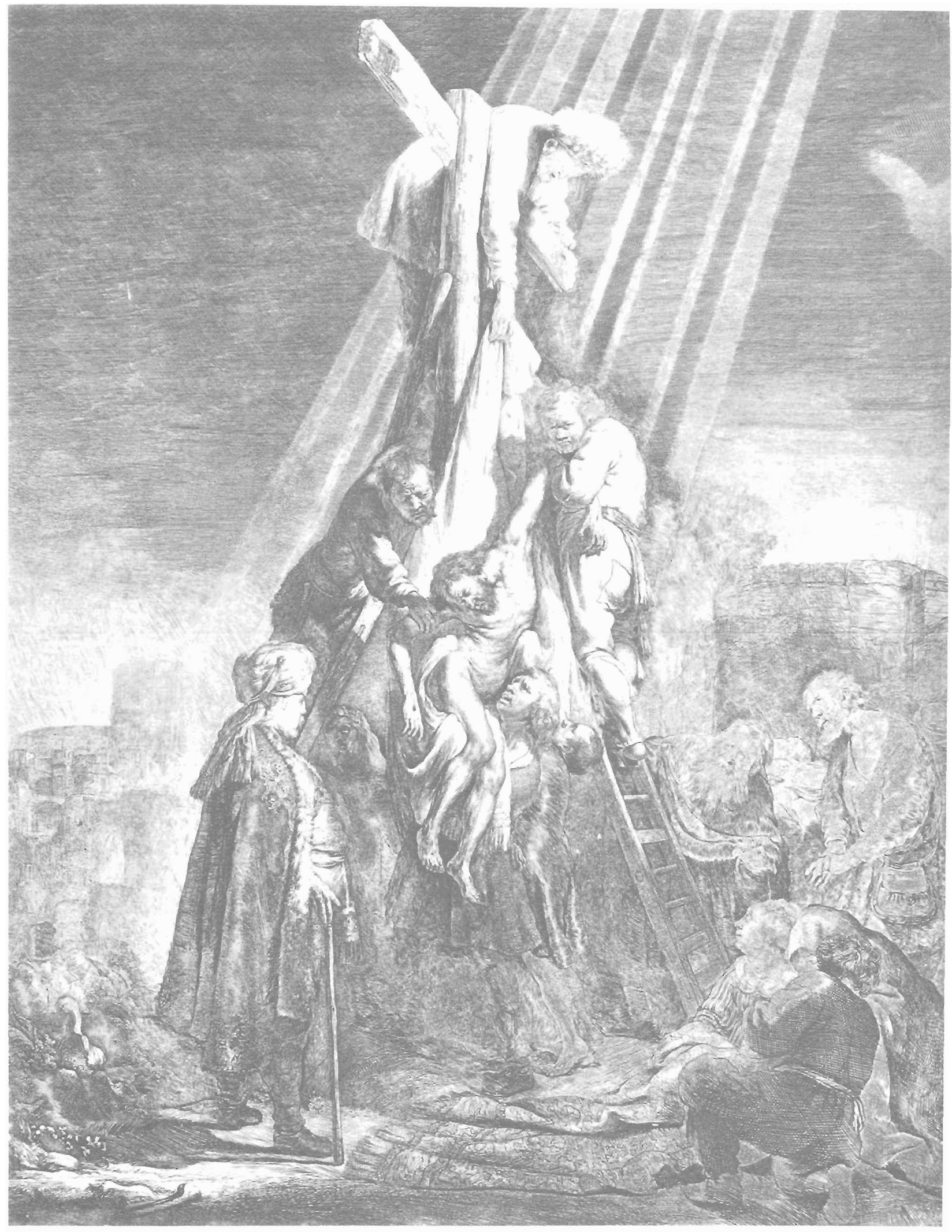

Rembrandt: The Descent from the Crost 


\title{
Not a bad 'Impression': a fine 'Rembrandt' Print in McGill's Collection
}

\author{
by Maria L. Brendel
}

In 1919 lvicGill received a seventeenth century print from the esiate of the Reverend Canon Thomas W. Mussen: The Descent from the Cross. In recent years this print has been dismissed by a local print dealer, on unspecified grounds, as a "bad impression, not by Rembrandt." This article contradicts the dealer's opinion and relates McGill's fine print (etching) to the plate from which two impressions were taken - one in the British Museum, London, the other in the Metropolitan Museum of Art, New York. Both have been directly linked to the Dutch baroque artist, Rembrandt Harmenz van Rijn, by their respective museum print experts and authenticated by the Amsterdam based committee, the Rembrandi Research Project.

En 1919, la succession du Révérend Canon Thomos W. Mussen donne à IIf Gill une gravure du KVIT siècle intitulée The Descent from the Cross (Descente de la Croix). Un marchand d'art a récemment dit de cette gravure, sans aucun motif, qu'elle étaii une "très mauvaise impression [et ne pouvait] être attribuée à Rembrandt". Cet article réfute l'opinion au marchand et met en iumière le lien qui existe entre la gravure en possession de McGill et la plaque à partir de laqueile deux impressions onété tirées, l'une figurant au British Museum à Londres et l'autre au Metropolitan Museum of Airi à Mew York. Toutes deux ont été directement attribuées au peintre baroque hollandais Rembrandt (Harmenszoon van Rijn) par les spécialistes de ces deux établissements. Elle a par ailleurs été authentifiée par le Rembrandt Research Project'

\section{Impression}

The Descent from the Cross

Etching and burin

$52.2 \mathrm{~cm} \times 41 \mathrm{~cm}$

Inscription: Rembrandt $f$. cum priyul 1633

Watermark to be determined by radiography

As

s rumor has it, potent but often false, I was told that the Rare Books and Special Collections at McGill University has a bad print, an imitation after Rembrandt, not worth mentioning. Swayed at first by rumor, visualizing a 'fake,' nearly undecipherable and full of ink spots printed from a botched copper plate, I did not initially insist on looking at it. How- ever, after considering that even a bad impression from that time has research potential and historical authority, I decided to view the print. ${ }^{2}$

"Excitement" is insufficient to convey the experience of seeing this large, visually demanding impression for the first time. The Descent from the Cross is a familiar composition, known from Rembrandt's painting of the famous passion cycle, obtained by Prince Frederick Henry of Orange during the 1630 s (now in Munich: Alte Pinakothek). The tableau Descent from the Cross had a particular meaning for Rembrandt. It won him the royal patronage for which most artists were striving at that time, but only few gained. This painting caught the eye of the Prince's secretary, Constantijn Huygens, who initiated the commission for six ensuing paintings that make up the passion cycle. ${ }^{3}$ (This information 
is derived from seven letters Rembrandit wrote to Huygens, the artist's onity known correspondence). To turn the painted composition into an impression was an established practice, especially of renowned works. Italian and German artists employed the grapho medicn to rake their works known. Engravirgs/etchings protected the authenticity of pictures - often copied via painting - and ensured a greater distribution, serving as advertisements for an artist's work, especialiy at the beginning of a career. in the Holland of Rembrandi, prints found a new circulation terrain due to increased prosperity among the populace which resulted in an expanding art market. ${ }^{4}$ Nadine M. Orenstein, print curator at the Metropolitan Museum of Art in New York, who publishec a critical analysis of the New York Descent" in 1995 , remarked "the grand scale and heary finish of [this] etching, which stands apart of Rembrandt's characteristically small, loosely drawn prints of the 1630 s, refects this purpose" ${ }^{5}$ : circulation.

ror connoisseurs and/or collectors, works in pririted form were a means to afford what was otherwise out of reach and out of sight. Once a painting entered a private collection, irrespective of how much it may have been temporarily part of contemporary discussion due to the work being seen in workshops by collaborators, assistants and visitors - it was no longer accessible for viewing. And only a few people could pay the hefty sums Rembrandt asked for his paintings, fees which even the Prince had to negotiate. ${ }^{6}$ The graphic medium remedied this situation. Rembrandt's colleague in the South (Flanders), Peter Paul Rubens, fully utilized the graphic arts. His famous tableau "The Descent from the Cross," (1611-12) was widely known only because it circulated in printed form. Rembrandt followed suit, publishing his impression with the privilege and protection of the state, a sort of copyright - indicated on the lower part of the print cum pryvl. ${ }^{7}$ Yet, unlike Rubens, who hired professional engravers (his 'Descent' was engraved by Lucas Vosterman) for a type of art clearly tedious, painstaking and time consuming, ${ }^{8}$ Rembrandt was attracted to the laboriousness of the medium, experimenting with etching and challenging the technique.

Interestingly, Rembrandt's etched oeuvre were widespread already in the eighteenth century. They were not only collected by connoisseurs, they were sought by artists as aids in the practice of their craft. ${ }^{9}$ Two sheets of sketches after etchings by Rembrandt are in the Yale Centre for British Art (New Haven: Mellon Collection). In these, the painter Joshua Reynolds exercised figural and facial expressions using the Dutch artist's self portrait and Rembrandt's young son, Titus, as his models. ${ }^{10}$

\section{Etching}

An etching is a kind of engraving in which the design is incised in a layer of wax or varnish on a copper plate. The parts of the plate left exposed are then etched - slightly eaten away - by the acid into which the plate is immersed after incising. Etching is one of the most facile of the graphic arts and the one mosu capable of subtleties of line and tone. ${ }^{11}$

Rembrandt's contribution to the graphic arts was already recognized in the seventeenth century by the Florentine art consultant and art historian Filippo Baldinucci. He wrote in 1686 of Rembrandt's "most bizarre manner which he invented for engraving on copper with acid, all his own, neither used again by others, nor seen again." 12 Prior to Baldinucci, a. British engraving-etching manual of 1660 makes mention of a novelty "The Ground of Rinebrant of Rein. ${ }^{13}$ In contrast to the professional French etcher Monsieur Callot, who used hard copper plates, ${ }^{14}$ the Dutch artist used a softer ground which allows greater freedom in drawing lines while also softening lines, resulting in subtle nuances and expressive power - visible in McGili's Descent.

\section{Lover of Art}

It must have been the drama, the appeal to emotion so well expressed in The Descent, that attracted Thomas W. Mussen to the impression. Mussen was "a man of culture and erudition, and a lover of Art," to use J. Douglas Borthwick's words. He possessed, as Borthwick wrote, "a large collection of coins and engravings by the old Masters, also a rare collection of books. These he got by great diligence and economy." is

Thomas W. Mussen (1832-1901) was born in Montreal and studied at McGill. After graduating, in 1856 he went on a grand European tour, returning in $1858 .{ }^{16}$ His travel account, given to McGill together with the Decretia gratian, a digest of Eccle- 
siastical Law, records a visit to a Paris book dealer. ${ }^{17}$ It may also have been in Paris where he obtained the Descent from the Cross. Paris, at that time, was a storehouse for Rembrancit oeuvre. ${ }^{18}$ Whatever the case, The Desceni from the Cross arrived in Montreal folded, but in superb condition. Folding the large print horizontally must have been necessary for the voyage. Surprisingly, the composition on the recto (front) does not suffer from the fold. in fact, the fold can be noticed only from the back (verso). Originally, the impression was on a thin sheet of paper, like the Metropolitan Museum 'Descent,' but backed by a second sheet (likely added in the late seventeenth century) in order to stabilize the work. This facilitated the fold and ultimately the journey across the Atlantic.

\section{Identical Prints}

Calling on Gary Tynski, Curator of Prints in McGill's Department of Rare Books and Special Collections, we compared the impression to good photographic reproductions of the prints in New York's Metropolitan iviseum of Art and Iondon's British Museum. The three prints are identical in sire, composition, technique and execution - except for slight variations in ink distribution, an occurrence contingent on manual application (ink is newly applied each time a sheet of paper is to be pulled from the plate). We conciuded that all three impressions must derive from the same plate. (The British Museum has another impression of "The Descent," an earlier attempt in which Rembrandt experimented with both the composition and technique. However, the plate was unevenly bitien by the acid, and turned out not to be a success. $)^{19}$

\section{Seventeenth Century Paper}

McGill's impression is on seventeenth rentury paper. This is the conclusion reached after examining the print together with Dr. Richard Virr, Curator of Manuscripts, McGill Rare Books and Special Collections, and after telephone-conferencing with Nadine M. Orenstein, in New York, which whom I discussed at some length the Metropolitan and McGill prints and their paper. McGill's Descent is printed on laid paper, used during the seventeenth century when paper was still hand pressed. Laid paper shows wire marks r:hich Gerive from the molds into which the cellulose mixture was placed. Interestingly, paper used at the time in Holland was most :ften imported from France or from the Far East and was often given Dutch watermarks. ${ }^{20}$ Watermarks are distinct designs - grapes, fleur de lis, foolscap, coats of arms - which link paper to particular houses of production. Sometimes a watermark also indicateci quality level. ${ }^{21}$ Watermarks are usually seen when the sheet of paper is held against a strong light (the New York 'Descent' has a grape watermark). Dr. Virr and: looked for this distinct feature but colild not discern it in McGill's impression. Cur investigation was hampered by the second sheet onto which The Descent has been placed. However, what human eyes cannot detect, beta- or X-radiography can determine, - a means currently used in the study of impressions from that period. ${ }^{22}$

\section{Large Impression}

The many Rembrandt's prints in circulation today are much smaller - at times minute - and display a greater sketchiness and decreased linearity, especially those produced in the 1640s and 1650s when he was even more experimental as an etcher. Large Rembrandt impressions - of which there are far fewer - have often been kept in private collections or given to institutions for academic and aesthetic purposes, as those in the present discussion. Within Rembrandt's own historical position, the imposing size of The Descent articulates his transcendence from mere craftsman to artist. He was recognized by the nobility. This is particularly relevant in comparison to Rubens, who had enjoyed royal patronage for decades (most particularly during the $1620 \mathrm{~s}$ and 1630s) and with it prestige, social mobility and financial security, a model example for Rembrandt. F.W.E. Holstein has advanced the view that Ruben's print, likely known to Rembrandt only through the impression, was a major influence on his painting. ${ }^{23}$ The Dutch artist, as is evident, based his painted composition, in part, on that of the Fleming, producing his own impression, also. For the print, howover, Rembrandt opted for large proportions and intensified dramatic expressions, setting himself apart from Rubens. 


\section{Particular Spirit}

In 1602 Iohn Evelyn, in his Sculptura, noted that "the incomparable Reinbraid's etchings and gravirgs ace of a particular spirit." 24 The particular spirit lies in the technical ability with which Reribrancit achieves a moment of dramate intensity, captwing the beholder's attention. In addition, the Descent is directly accessible to the viewer, emphasized in a number of ways.

First, his figlires are not idealized, muscular with heroic proportions like those of Rubens, who was much under the spell of antiquity. Cnlike Rubens, Rembranct never went south of the Alps on the grand Italian tour and was never exposed to antique sculptures and italiar Renaissance art first-hand (only through graphic reproductions). He stayed nome and it served him well His unidealized figures, homely settings and stress on human emotions carry the atraction viewers have toward his art, initiating a dialogue between ariwork and beholder.

Second; the effects in his tableaux of colour and thick paint applications are replaced in his etchings by the play of light and shadows. For example, rays of supernatural light fall onto a 'human' Christ, illuminating a face marked by pain - a moving expression fascinatingly rendered in a difficult medium. The light suddenly stops on the ladder leaning against the cross. It peters out to the left, highlighting the visage of the turbaned gentleman, Joseph of Arimathea, into whose tomb the corpus was laid. Light is used as a narrative device, acting like words in a text.

Third, Rembrandt focuses less on the pictorial and more on narrative elements, emphasized further through the figures' postures, facial expressions and their distribution within the composition. Repeatedly, in his works figures are included in the margins, absorbed in something else, distant in their placement and unaware of the main event. In The Descent, two seated gentlemen, at the very left of the composition, one wearing a top-hat, appear to be involved in a conversation - ignorance or comic relief?

Fourth, McGill's The Descent is not just black and white. It consists of a multitude of tones of grays as well as whites, which with a sophisticated employment of line - cross hatching, straight and curvilinear lines, shallow and deep cutting - give both emotional and spatial depth to this setting. Depth in space is most particularly underlined on the sides where a townscape is seen, set back illusionistically through iighter tones of gray. The central darker area in the centre front, especially the area under the cross, and the placement of a kneeling figure at the right viewing the event, are compositional devices bringing the scene outward toward the viewer, while leading the eye and ultimately the beholder into the fictional space. ${ }^{25}$

Another device employed here to engage the viewer is a figure's gaze, making eye contact with the beholder. This feature was denounced by Christopher White, who was evidently taken by this image of The Descent and analyzed the print at great length. White described the figure standing on the ladder looking out, "with features resembling Rembrandit, a vulgar touch and distracting. 26

\section{Collaborate efforts}

Rembrandt, who was twenty-seven years old in 1633 , the date of both painting and etching, was gaining fame. But at this time he must have sought help and advice from engravers. Ludwig Münz attributes a large number of prints to a combination of master and assistants, among them The Descent from the Cross. This counter-argues the opinion of C. White who credits Rembrandt alone for the execution. ${ }^{27}$ McGill's impression appears to show more than one hand and it is very likely that, at this early stage in his career, Rembrandt worked with the experienced engraver Jan Van $\checkmark$ liet, as $N$. Orenstein suggests. The following excerpt from Orenstein's close examination and assessment of the New York 'Descent' is worth including here, for it deepens our understanding and appreciation of McGill's impression:

Clearly the Descent was etched in several stages; successive layers of drawing, hatching, and redrawing are visible throughout. Certain passages of hatching have been mechanically applied, while others, which can frequently be discerned underneath the heavy layers of hatching display the spontaneity typical of Rembrandt's lines. Large areas of the sky and the buildings in the left background, for example, are covered with repetitive diagonal hatching done with the burin, the tool of the professional en- 
graver. The original execution of the buildings underneath the hatching, however, is lively and loosely sketched with thin etched lines, a stylistic characteristic associated with the master. Elsewhere thin lines are retraced with thicker, heavy-handed etched ones, such as those of the outlines of the brocaded cloak on the ground in the center. And strokes too uniform for Rembrandt's hand are in evidence in other parts of the composition: [like] the parallel lines that define the shimmering tunic of the man standing to the left of the ladder. This alternately spontaneous and mechanical handling and rehandling can be explamed only if the etching is considered the result of a series of interchanges between Rembrandt and another artist. Rembrandt must initially have sketched much of the composition onto the plate, but another hand seems to have filled in and reworked many areas under his direction. ${ }^{28}$

Collaborate efforts were normal workshop procedures in seventeenth century Holland, a fact increasingly accepted in scholarship, at times even emphasized but unfortunately vehemently rejected by dealers. For too long academic interaction with Rembrandt's art and studio dynamics were based not on actual practices but on modern interpretations. The thesis went like this: Rembrandt worked without pupils and/or assistants; he was the lonely genius who would create only in isolation, tortured by his muse. Acceptance of collaboration is very recent and contrary to scholarship produced during the nineteenth and much of the twentieth century when the focus, obsessively, was on one master, one name, one author. This persistence was a lingering shadow of the nineteenth century Romantic cult of the genius, who was perceived as an outcast of sorts. Clearly this was a type of scholarship that suspended knowledge for belief, in which Rembrandt was caught up for too long at the cost of many contemporary masters, their contribution and their art.

Authorship is an exclusionary concept. "Authorship," as J. Culler puts it, "is not given but produced; what counts as authorship is determined by interpretive strategies." 29 Our interaction, our interpretative engagement with the author(s) has to change, giving a greater latitude to the creative forces that shape an artwork and accepting the truth that an artist did not, could not, work in isolation, especially not one with the prolific output of Rembrandt. We have to keep in mind that his large oeuvre includes paintings and drawings in addition to etchings.

The quotation inark in which Rembrandt's name is set in the titie of this paper is therefore not a sign of uncertainty of attribution. Quite the contrary, it is to link Rembrandt's name directly to the work: but to also pay tribute to the labour, the contribution of ihe other(s) for whom names are still being sought.

\section{Notes}

1. The impression is discussed in Corpus II, closely associated with the compositional development of the Munich painting: The Descent from the Cross. J. Bruyn, B. Haak, S.H. Levie, P.J.J. Van Thiel, E. Van De Wetering in collaboration with L. Peese Binkhorts-Hoffschelte and J. Vis, A Corpus of Rembrandt Paintings II, 1631-1634 (Dordrecht and Boston: Martinus Nijhoff Publishers), 1982, 278-287

2. To Nadine $M$. Orenstein, print curator at the Metroplitan Museum of Art, New York, I extend my thanks for enthusiastically offering me her time and expertise Thanks are due to Dr. Richard $\checkmark$ irr, curator of manuscripts, and Gary Tynski, print curator, both of McGill's Department of Rare Books and Special Collections. R. Virr kindly pointed me to bibliographic sources and to McGill's T.W. Mussen File. My appreciation is extended aiso to Andrea Fitzpatrick for her editing skills. Special thanks go to Dr. Hans Möller, founder and first editor of Fontanus, who shared my enthusiasm for the print.

3. Rembrandt painted this image on panel (like Rubens' 'Descent from the Cross'), although the other tableaux of the Passion cycle are painted on canvas. This may indicate that his Descent was initially conceived as an independent work. Christopher Brown, Jan Kelch \& Pieter van Thiel, Rembrandt: the Master $\&$ his Workshop (New Haven and London: Yale University Press and National Gallery Publications), 1991, 156-160 (Henceforth referred to as Brown et al).

4. For the art market in Holland see: Svetlana Alpers, Rembrandt's Enterprise. The Studio and the Market (Chicago: The University of Chicago Press), 
1988, $88 \mathrm{ff}$. and Simon Schama, The Embarrasment of Riches. An Interpretation of Dutch Culture in the Golden Age (London: Fontana Press), 1987, 290 ff. and Neil de Marchi and Hans J. van Miegrot, "Art, Value and Market Practices in the Netherlands in the Seventeenth Century," The Art Bulletin; September, 1994 .

5. Nadine M. Orenstein, "Rembrandt's Prints and the Question of Attribution," pp. 201-102 and catalogue entry "The Descent from the Cross," pp. 228-229, both in Rembrandt/Not Rembrandt in the Metropolitan Museum of Art: Aspects of Connoisseurship, vol. II (New York: Harry N. Abrams, Distributor), 1995; and Christopher White, Rembrandt as an Etcher. A study of the artist at work (London: A Zwemmer Ltd.), 1969, vol. 2, for reproduction of prints in the British Museum pp. 22-24, and vol. 1 for text, pp. 33-36.

6. Prince Frederic Hendrik of Orange did not pay the full price Rembrandt asked. Brown et al, 156.

7 The Descent from the Cross together with Christ before Pilate - perhaps pendant pieces - are the only impressions by Rembrandt with the incription cum pryvi, or cum privile, as N. Orenstein noted, 228.

8. For Rubens' engraved 'Descent from the Cross' see White, vol. 2, 22 or J. Bruyn et al, Rembrandt Corpus II, A 65.

9. Jeroen Boorngard and Robert W. Scheller, "A Delicate Balance: a brief Survey of Rembrandt Criticism," in Brown et al, 107.

10. Reynolds' sheets are reproduced on page 108 , figures 135 \& 136 in Brown et al.

11. G. Tansey, Gardner's Art Through the Ages, 8th edition (New York: Harcourt Brace Jovanovich), 1986, 978 .

12. F. Baldinucci, Cominciamento e progresso dell' arte in rame cole vite molti de' piu eccelenti Maestri della stessa Professione (1686), 2nd ed. 1767,169 , cited by White, 9. Baldinucci helped form the drawing collection of Cardinal Leopoldo de Medici, purchasing paintings for Duke Cosimo III de Medici. The Oxford Compansion to Art, ed. Harold Osborne (Oxford: Clarendon Press), 1970, i02.

13. The whole Art of Drawing, Painting and Etching, authors are not cited, (London, 1660), known from Cochin's edition of 1758 of Bosse's Traité des Maniers de Graver, cited by White, 12.
14. White, 12.

15. Reverend J. Douglas Borthwick, History of the Diocese of Montreal 1850-1910 (Montreal: John Lovell \& Son, Limited), 1910, 120-122. R. Virr referred me to this source.

16. Borthwick, 120.

17. T.W. Mussen File, Rare Books and Special Collections, McGill University.

18. For information on art dealings see Jan Kelch, Bilder im Blickpunkt: Der Mann mit dem Goldhelm (Berlin: Gemäldegalerie), 1986, $11 \mathrm{ff}$.

19. Orenstein, 228. For the reproduction of this plate see White, vol. 2, plate 23.

20. For some of his smaller impressions Rembrandt turned to Japanese papers, reaching Holland from the Dutch trading post at Nagasaki through the port of Batavia in Java. It was known as Indian paper as it came through the Dutch East India company. White, 13-14.

21. The Plantin publishing house in Antwerp, for - instance, was ordering paper by the watermark and size. Philip Gaskell, An Introduction to Bibliography (Winchester: Oak Knowll), 1994, 61.

22. Orenstein, 203.

23. F.W.E. Hollstein, Dutch and Flemish Etchings, Engravings and Woodcuts, ca. 1450-1700 (Amsterdam), 1949, for Rembrandt's prints see vols. XLII (text), p 31 and XIX (plates), compiled by Christopher White and Karel G. Boon; cited by Orenstein, 228.

24. cited by White, in his Introduction, p. ii

25. White, vol. 1,36 .

26. White, vol. 1, 36 .

27. Ludwig Münz, A critical Catalogue of Rembrandt's Etchings (London), 1952, 197-198 cited by White, 34.

28. Orenstein, 228.

29. Culler is referred to by Mieke Bal and Norman Bryson, "Semiotics and Art History," The Art Bulletin, June, 1991, 181. 


\section{Ottoman-Turkish Manuscripts in the Islamic Studies Library and Other Libraries of McGill University*}

\section{by Adam Gacek and Ali Yaycioğlu}

The present paper consists of descriptions of 48 individual Ottoman-Turkish texts as found in 35 volumes preserved in the Islamic Studies Library, the Department of Rare Books and Special Collections and the Osler Library of the History of Medicine. Although small in size, the collections of Ottoman-Turkish mantiscripts at McGill are interesting not only from the point of view of scope (some 15 broad subjects) but also because they provide us with a wealth of paleographical and codicological data, which printed catalogues do not always record.

Le présent article se compose de descriptions de 48 textes écrits en turc-oltoman et recueillis dans 35 volumes préservés à la Bibliothèque d'études islamiques, au Département des livres rares et collections spéciales, et à la Bibliothèque Osler de l'histoire de médecine. Bien que peu nombreuses, los collections des manuscrits turc-ottomans à l'Université McCill sont intéressantes non seulement du point de vue de l'ampleur (une quinzaine de sujets) mais aussi parce qu'elles fournissent une abondance de données paléographiques et codicologiques, qui ne sont pas toujours incluses dans des catalogues imprimés.

"We acknowledge here. with gratitude, the generous financial support of Prof. A. Üner Turgay, Director of the Institute of Islamic Studies, for the research done on this collection. We would also like to thank Prof. Mehmet Kalpaklı and Steve Millier for their editorial assistance.

\section{Introduction.}

$\mathrm{T}$ he collections of Islamic manuscripts at McGill University cover the four major languages: Arabic, Persian, Ottoman Turkish and Urdu. The Arabic collections have now been described in a recently published union catalogue and four articles. ${ }^{1}$

The present paper discloses for the first time the hidden treasures of the Ottoman manuscripts which are housed in the Islamic Studies Library (29 vols.), the Department of Rare Books and Special Collections ( 4 vols.) and the Osler Library of the History of Medicine (2 vols.). This small collection consists of 48 main titles. Most of the manuscripts in the Islamic Studies Library were acquired on the recommendation of Niyazi Berkes, a former professor of the Institute of Islamic Studies,
McGill University, from Thornton's of Oxford in October of 1963.

Although small in size, this collection covers a remarkably wide range of subjects. Best represented is sufism with 15 texts (nos, 3, 19, $21,25,27,31,33-36,39,44-47)$. It is followed by ethics (nos. 1, 10, 16, 26, 28, 37, 43), Islamic law, includirg shari a manuals, fetvá collections and legal practices (nos. 4, 5-6, 11-12, 41), poetry (nos. 8-9, 14, 40), medicine (nos. 22-24, 32), and ibādāt (nos. 17, 29). The other subjects represented are: codes of law (Kănūnnäme) (no. 18), Ottoman bureaucracy and statecraft (no. 38), recitation of the Qur'ān (no. 20), fütürvetnāme (no. 13), calendar (no. 2), history (no. 48), late Ottoman military organization (no. 7), calligraphy (no. 15), 
interpretations of dreams (no, 42) and an encyclopedia of various disciplines (no. 30).

The collection contains a complete and elegantly calligraphed, Arabic text of the famous poem Bad' al-amāi (no. 26). In addition, eleven compositions (nos. 3, 17, 19, $26,36-37,40-41,43-45)$ are translations and/or commentaries, the original texts being either in Arabic (nine texts) or Persian (two texts). (of particular interest is an apparently unknown translation of the well-known Persian sufi work Tazkirat al-awliyā' (Tezkiret ül-evliyā'), no. 45 ,

From a paleographical standpoint, the collection also features a variety of scribal hands. The predominant script is neshi (nos. 1 , $3,15,17,19,21,22,26,27,29,32,36,41,43$, 44), neshī with elements of Ottoman ta'lik (nos. $6,12,24,25,45$ ), icảzet (nos. 12 c.II, 18) and rik'a (including rik'a. kırması) (nos. 7-8, 30, 4648). Of special interest here are: (i) $A h k \bar{a} m-I$ $s a \bar{l}$ (no. 2) calligraphed in three scripts: neshī, sülüs and tevkī', (ii) an exquisite copy of

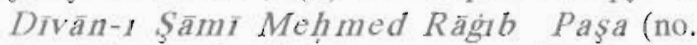
9) calligraphed in Persian nasta' $l i ̄ q$, (iii) nos. 12 c. II and 1.9 with colophons in icāzet, and (iv) an ownership statement (no, 5) in siyākat script.

Most of the colophons and ownership statements are in Arabic. The transcription statements include, on the one hand such expressions as harrarahu or tahrir, sawwadahu or taswid and katabahu or kitābah, and on the other, "an yad and min yad, as opposed to the more usual 'alá yad (in the hand of). Among the expressions introducing statements of ownership are șāhibuhu, istașhabahu, tamallakahu, min mumallakāt, qad tamallaka, dakhala fì milk and intaqala bi-yad.

Among these: statements there are three important attestation/reading notes (imdā') to be found in no. (3. The use of chronosticons for the date of composition is attested in nos 14,19 , 21, 29 and 44. In terms of provenance we find the following towns and/or villages indicated: Kalíbūlī, i.e. Gelibolu (no. 5), al-Urmiyah (no. 11), Țirnuvá (no. 14), al-Qusțanținiyah (no. 21), Tubkhānah, i.e. Tophāne (no. 41) and Qarahyaqah, i.e. Karayaka (no. 45). There are 20 dated texts, of which the oldest is a copy of Minhāc ül-Ísläm transcribed in $906 / 1559$. Three other early manuscripts deserve to be mentioned here. These are Gencīne-i rāZ (no. 14) copied in 1002/1593, 'Imād ül-İslàm (no. 17) copied in 1069/1659 and Biżă'at ülḥ̈̈kkām fì ị̣kām il-aḥkām (no.5), which apparently was copied in 1080/1669-70, i.e., twenty years before the death of its author Hāibzäde: Muhammed bin Muștafá bin Maḥmūd el-İstanbūī. Among the other dated manuscripts, six were transcribed in the $12 / 18$ th and nine in the 13/19th centuries. One (no. 48) was copied as late as 1929 .

All manuscripts were copied on European or European style laid. or wove paper. Wove paper was used in nos. $8,9,21,46,47,48$; no. 9 in particular carries an imitation watermark: BATH. A number of papers were tinted (coloured) (see e.g. nos. 9, 19, 26, 27, 4.4). The laid papers, were usually well-glazed and feature a wide assortment of well-known watermarks. These are:

- anchor in a circle (nos. 14, 20, 29)

- crown-star-crescent (crown surmounted by a star and a crescent) (nos. 6, 17, 18, 20, 32)

- crown and grapes, i.e. bunch of grapes surmounted by a crown (nos. 2, 11, 12c. II, $15,41,44)$

- diadem (no. 11)

- $\quad$ eagle displayed (nos, 1, 19, 36, 41, 44, 47)

- eagle displayed, in a coat of arms (no. 27)

- lion passant guardant (nos. 3, 12c I, I9, 26)

- lion passant guardant, in a coat of arms (nos. 1, 31)

- lion rampant, in a coat of arms (nos. 12c. I, 25, 31, 36, 44, 47)

- paschal lamb (no. 43)

- PICARDO; BP (no. 30)

- scissors (no. 29)

- six-pointed star (no. 11)

- three crescents (nos. 1, 45)

- three crescents with human profiles (nos. 1, 22)

- three hats (nos. 1, 4, 11, 17, 19, 25, 29, 45).

As far as illumination is concerned most of the manuscripts in this collection. were rubricated and gold used for thick rule-borders and headpieces. The use of multiple coloured inks in the text is beautifully illustrated in 
Ahkām-l sāl (no. 2). Thirteen headpieces can also be found in the collection (nos. 1, 3, 9, 12c. II, 25-27, 41, 43, 44). There are four exquisitely executed headpieces in Divān-i Şāmi Meḥmed Rāğb Paşa (no. 9).

The traditional envelope flap (mikleb) in bookbinding was used in only 16 cases. Six bookcovers have no flap (nos. 5, 9, 30, 31, 36, 44) while the Western influence is even more visible in nos. 17, 20,47 and 48. It is interesting to note that in ten cases paper was used as a covering for the bookcovers and that six volumes were covered with marbled paper (ebru). For the more elegant bindings red or brown leather was used. This was usually blindor gold-stamped, the typical decoration consisting of centre-medallions with pendants and border decoration. The best examples here are nos. $2,9,25,27,44$. In one case (no, 41) the center-piece was onlaid and in another (no. 3) velvet was used for the central panels.

The transliteration employed here is for the most part the romanization scheme for Ottoman- Turkish developed by E. Birnbaum², although we have been forced to use the Arabic transliteration scheme of the Library of Congress for names and phrases written in an exclusively Arabic grammatical context. This is the case especially in colophons and most of the ownership statements. For names of Turkish origin but used in an Arabic context, we have provided the Turkish form in parentheses following the Arabic version, e.g., Tubkhānah (Tophane). Furthermore, short incipits have been supplied for the items, which differ and/or could not be found in any catalogues.

\section{Abbreviations}

AMM

BM

$\mathrm{BN}$

$\mathrm{EHB}$

Özege, M. Seyfettin. Eski harflerle hasılmış Türkçe eserler kataloğu. Istanbul, 1971-9. 5 vols.

EI

The Encyclopaedia of

Islam. 2nd edition.

Leiden, 1960-

GAL Brockelmann, Carl.

Geschichte der

Arabischen Litteratur

Leiden, 1943-1949. 2

vols; Supplement,
Leiden, 1937-1942. 3

vols.

(jSO)

Babinger, F. Die

Geschichtsschreiber der

Osmanen und ihre

Werke. Leipzig, 1927.

$\mathrm{HC}$

Yahya, Osman. Histoire et classification de l'oeuvre d'Ibn 'Arabi; étude critique. Damas, 1964. 2 vols.

IA

ISL

Islarn Ansiklopedisi. Istanbul, 1950-86.

Islamic Studies Library.

McGill University.

Osler Library of the

History of Medicine.

McGill University.

OM

Mehmed Tāhir, Bursalı.

'OS manl Mii' elififferi.

Istanbul, 1333/1915. 3

vols. 
PFA

NE:

RBD

SF

TA.

TGK

$\mathrm{TH}(2)$
Ritter, Hellmut. "Philologika

XIV. Fariduddin "At $t$ är

II". Oriens, 11 (1958): 70-76.

Nev'ì Efendi. Netāyic ế-fünün (llimlerin özü), ed. Ömer

Tolgay. Istanbul, 1995.

Department of Rare Books and Special Collections. McCill University.

Şem 'dânî-zâde Fındıklı Süleyman Efendi. Şem 'dânîzâde Findıklı Süleyman Efendi Târihi. Mür'it't-Tevârih, ed.

Münir Aktepe. Istanbul, 1976.

Türk Ansiklopedisi. Ankara, 1948-1984.

Kut, Günay. Terciman Gazetesi Küt üphanesi Tiükçe Yazmalar Kataloğu. Istanbul, 1989.

TH(1) Flemming, Barbara. Türkische Handschriften, Teil

1. Wiesbaden, 1968.

Götz, Manfred. Türkisclie

Handschriften, Teil 2.

Wiesbaden, 1968.
YE

$\mathrm{TH}(3)$

$\mathrm{TH}(4)$

$\mathrm{TH}(5)$

THB

THR

TSM

VH

The Manuscripts
Sohrweide, Hanna. Türkische Hand'schriften, Teil 3.

Wiesbaden, 1974.

Götz, Manfred. Türkische Hand'schriften, Teil 4.Wiesbaden, 1979.

Sohrweide, Hanna. Türkische Handschriften, Teil 5. Wiesbaden, 1981.

Pertsch, Wilhelm. Verzeichniss der türkischen Handschriften der Königlichen Bibliothek zu Berlin. Berlin, 1889.

Rado, Sevket. Türk hattatlart. Istanbul, 1983.

Karatay, F. E. Topkap!

Sarayı Müzesi

Kütüphanesi Türkçe

Yazmalar Kataloğu.

Istanbul, 1.961. 2 vols.

Tschudi, Rudolf. Das Vilâjetnâme des Hâdschim Sultan: cine türkische Heiligenlegende, Berlin, 191.4.

Yunus EInre Divânı, ed. Burhan Toprak. Istanbul', 1960.
1 (ISL 57)

\section{$\bar{A} d \bar{a} b$ ül-menāzil}

Author: ['Abdüllatif bin Durmuş Fakih bin Selim Zeki Karamani] (fi. $2^{\text {nd }}$ half of $10 / 16^{\text {th }}$ cent.). - Composed in $985 / 1577$ (f. 2a). Compendium on ethical and moral issues related to women and family life.

ff. [8] 271; $220 \times 165 / 170 \times 108$ mm; 23 lin. Laid European paper; watemarks: 1. eagle displayed, 2. coat of arms (lion passant guardant), 3. Three crescents with human profiles, 4. three crescents, 5. three hats. Elegant neshĩ hand. - Simple golden headpiece.Double-line rule-borders. - Catchwords. - Text. rubricated (keywords, quotations and omissions in the margins). - Overlinings. - Paper covered boards with flap (flap detached).

Anonymous copy, transcribed in Cemazi elevvel 1233/1817. - Table of contents (ff. [2-5]).Former owner: Sayyid Sayf Allāh (f. la).

Ref.: TH(2), 176; OM, I, p. 130. 
2 (RBD 1)

\section{[Aḥkăm-l săl]}

Calendar for the year Rabí ${ }^{6}$ I $1129 / 1716$ to Rabí I 1130/1718, dedicated to Sultan Ahmed III (reg. 1115/1703-1143/1730).

ff. [10]; $290 \times 185 / 210 \times 130$ mm.; lines vary; text in columns - First folio blank (text begins on f. 2b). - Laid European paper; watermark: crown and grapes. - Executed in elegant neshi, sülüs and tevkí scripts (Fig. 3).- (Golden ruleborders. - No catchwords. - Polychrome text. Golden vegetal designs (ff. 9b-10a). - Goldstamped light brown leather binding; with flap.

Anonymous and undated copy (ca. 1129/1716). Bookplates: Henry B. H. Beaufoy F. R. S. and Presented to the Redpath Library Mccill University from the Alice E. Redpath Fund.

\section{3 (ISL 140)}

\section{Behcet ül-esrātr ve lem at ül-envãr}

Anonymous translation of Umun al-barähinn, also known as Maraàqib al-Shaykh Ahmad al-Rifă 'T, hagiography of the founder of the sufi order, alRifă'îyah, Alumad al-Rifãì (d. 578/1182) (see GAL, SI, 781; EI, VIII, 524b).

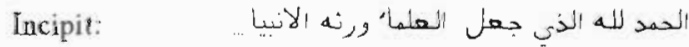

ff. [121]; $225 \times 165 / 140 \times 80 \mathrm{~mm}$; 13 lin. Buff, tinted and glazed laid European paper; watermark: lion passant guardant, FP; VG. Clear neshī hand. - Crudely illuminated doublepage frontispiece. - Borders and discs filled in copper-based ink- Catchwords.- Text rubricated. - Red leather binding with velvet center panels and flap.

Anonymous and undated copy $\left(13 / 19^{\text {th }}\right)$. - Clean copy. - Title with Seal of Solomon above besmele. - Acquisition note, dated 1282/1865-6, on fly-leaf (purchased for the sum of 30 gurus).

$$
4 \text { (ISL 104) }
$$

\section{Behcet ül-fetầá}

Author: [Yeñişehirli 'Abdulläh Efendi] (d. 1156/1743)
Incipit:

$$
\text { يار مسى اولوب معذور اولان زيد يار مسنى... }
$$

ff. [3] $346[+1] ; 255 \times 140 / 185 \times 70 \mathrm{~mm}$; 23 lin. - Laid European paper; watermark: three hats. - Elegant Ottoman ta'lị hand. - Singleline rule-borders in red. - Catchwords. - Text rubricated (el-cevāb, titles). - Blind-stamped brown leather binding with flap.

Anonymous and undated copy (late $12 / 18^{\text {th }}$ cent.). - Table of contents (ff.[Ib-3a]). Marginal glosses in different hands. - Additional fetvás in a different hand (probably that of a former owner) taken from various textual sources and different muftīs. - Two seals: 1. Muh ammed Hüsāmeddīn (f. [3a]), 2. Halìl Hilmì (f. [ $[\mathrm{b}]$ ). - Inaccurate identification of the book by a second hand as Fetãvá-yı Behcet Efendi (f. [la]).

Ref:: $\mathrm{TH}(5), 112$ (different incipit); OM, I, p. 363; EHB, I, p. 122.

$$
5 \text { (ISL 147) }
$$

\section{Bizà̃at ül-ḥükkām fi ị̣kām il-ahkām}

Author: Häcibzāde Muhammed bin Mustafá bin Maḥmūd el-İstanbūlī (d. 1100/1688-9). - Treatise on Ottoman legal practice including sample legal decisions issued by shari'a courts, compiled between 1.064/16534 and 1081/1670-1 (!).

ff. [4] $157 ; 210 \times 165 / 170 \times 100 \mathrm{~mm}$; 25 lin. Laid European paper; watermark: unidentified. Single-line rule-borders. - Neat Ottoman ta'lik hand.- Text rubricated.- Blind stamped; brown leather binding; no flap.

Copied in Kalībūī (Gallipoli or Gelibolu) by (tahrīr "an yad) Hasan Sidqi, secretary at the court (mahkamah) of Gallipoli, 1080/1669-70. Table of contents. - Omissions in the margins. Ownership statements and two seals (f. [1 a]) by: 1. (bādalat) Muhammad ibn Khalìl, 2. (min mumallakāt) Ạ̣mad Nazị̂ ibn Husayn ibn Muhammad ibn Aḥmad al-Samāqawīi, 3. (săhịib) İbrähưm bin Mollā 'Ali...(?), dated 1211/1796-7 (siyak āt script). - Inserted in an envelope: an illuminated calendar for Ramadān (wove paper, $750 \times 75 \mathrm{~mm}$.).

Ref.: TSM, I, 318; OM I, p. 280. 
6 (ISL, 154)

Defter-i sukük

Author: [Mehmed bin Derviş Mehmed], known as Șāni-i Edirnevĩ (d. 1033/1624).Manual of sample legal decisions issued by shari'a courts, composed in 1033/1623-4.

ff. $39 ; 260 \times 145 / 150 \times 80 \mathrm{~mm} ; 15$ lin. - Laid European paper; watermark: crown-starcrescent; trefoil PA. - Neshī/ Ottoman ta'lik hand. - Catchwords. -Text rubricated. - No binding.

Anonymous and undated copy (copied possibly ca. Cemāzi el-evvel 1109/1697, see no. 3 below). - Incomplete text (bāb 1-4 only). - Some marginal glosses. - Three ownership statements and two seals, one in the shape of a lion with a halo (f. la) by: 1. (tamallakahu) 'Alī' Qabazādah al-Qayșarawi, 2. 'Âli bin eş-Şeyh 'Ömer, 3. note on the birthday of Matlabacı Mahmund (elebin's daughter (13 Cemāzi el-evvel 1109/1697). Three attestation / reading statements (imḍā')

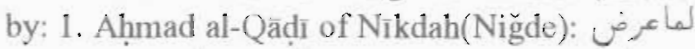

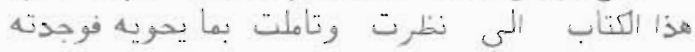

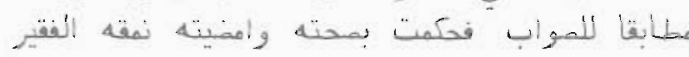

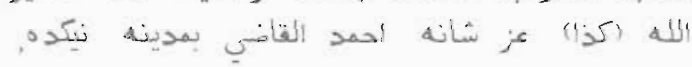

2. "Alī ibn 'Úmar al-Mudarris, 3. 'Alī alMawāì̄. - Some verses and notes (f. 39b).

Ref: TGK, I, 57.

$$
7 \text { (ISL 171) }
$$

Devlet-i 'aliyye-yi 'Oșmāniye 'niñ tensikāt-1 askerīyesi

Anonymous compilation of writings on history of Ottoman military and copies of some legal documents on late $19^{\text {th }}$ or early $20^{\text {th }}$ cent. Ottoman military organization.

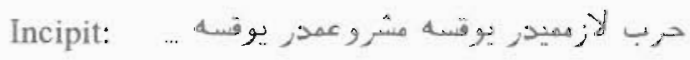

ff. $[474] ; 194 \times 130 / 170 \times 110 \mathrm{~mm}$; 13 lin. Laid paper; no watermark. - Ottoman rik'a hand. - Text in black ink. - No catchwords, - Black quarter-leather binding with center stamp of Ottoman dynasty; no flap.

Anonymous and undated copy (early $20^{\text {th }}$ century).
8 (ISL 174)

\section{Dĩvān-I Kaygususuz Sulțān}

Author: Kayg usuz [Abdāl] (fl. $9 / 15^{\text {th }}$ cent.).

ff. [85]; 285 x $195 / 220$ x 135 mm.; lines vary.Wove and. laid paper. - Riḳ'a ḳrması hand. Text in columns and compartments. - Some catchwords missing.- Some lacunae (ff. 79, 8183).- Double-line, dark-red rule-borders. Modern green cloth binding.

Anonymous and undated copy (late $13^{\text {th/ }}$ / early $20^{\text {th }}$ cent.), - Some corrections in pencil.

Ref:: $\mathrm{TH}(1), 424$.

$$
9 \text { (RBD 2) }
$$

\section{Dîān-J Şāmi Meḥmed Răğ}

Author: Rāgıb Paşa, known as Hoca Mehmed, or Koca Rảgıb Paşa (d. 1176/1763).

Incipit:

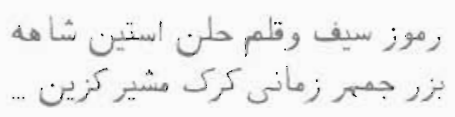

ff. [128]; $205 \times 125 / 135 \times 80$ mm.; 15 lin. Colored wove European paper (light blue, pink and yellow); imitation watermark: BATH (f, 2).Calligraphic Persian nasta'līq hand. - Four exquisitely illuminated headpieces (ff. $1 \mathrm{~b}, 6 \mathrm{~b}$, 16b, 18b) (Fig. 1). - Golden rule-borders. Catchwords. - Chapter headings in blue and red.Blind and gold-stamped red leather binding; no flap.

Copied (taswī') in Dhu al-Hijjah 1260/ 1844 by Muḥammad "Alī ibn Muḥammad Ṣādiq alShīrāzi.

Ref:: TH(3), 247 (different incipit); EI, VIII, pp. 390-391; EHB, I, p. 293.

$$
10 \text { (ISL 50) }
$$

\section{Fażīletnāme}

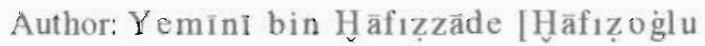
Derviş Mehmed, known as (mahlaș) Yemint] (fl. $1^{\text {st }}$ half of $10 / 16^{\text {th }}$ cent.).- Mesnevi 
extolling the virtues (fażilet) of 'Alr and his family.

ff. [24a-256a] 1-235 (original foliation); (for other codicological and paleographical details see no. 31).

Anonymous and undated copy (ca, $1263 / 1846-$ 7; see no. 34), - Table of contents (ff. 22b-23b).

Ref: TH(2), 254-6; EHB, I, p. 386.

\section{1 (ISL 11)}

[Fetävá-yI "Alî Efendi]

Author: [Çatalcalı 'Alī Efendi] (d. 1103/1692).

ff. [6] $336 ; 305 \times 165 / 185 \times 65$ mm.; 31 lin. Laid European paper; watermarks: 1. six-pointed star GV (f. [1]), 2. three hats, 3. crown and grapes, 4. diadem GB. - Neat Ottoman ta 'lik hand (Fig. 8), -Single-line rule-border with outer frame in red. - Text rubricated (el-cevāb and subtitles). - Catchwords. - Marbled paper covered boards, with flap.

Copied by (sawwadahu) Sulaymān ibn Hamzah in 1189/1775-6 in al-Urmiyah.- Clean copy.Table of contents (ff, [1 b-3a]).- Ownership statement on f. [1a]: (tamallakahu) Ḥâfiz: Ibrāhīm, dated 1219/1804-5.

Ref.: TH(3), 110; TH(4), 79; EHB, I, p. 402.

\section{2 (ISL 56 and 169)}

\section{Fetāvá-yI 'Ațā'ullāh Efendi}

Author: [Minḳārīzāde Yahyyá Efendi] (d. 1088/1677). - Compiler: [Meḥmed] "Aṭâ."ullāh Efendi (d. 1127/1715).

Copy I (ISL 56): Title on tail. - ff. [5] $396[+4$. blank] ; $240 \times 170 / 180 \times 105$ mm.; 27 lin. Laid European paper; watermarks: 1. coat of arms (lion rampant), 2. lion passant guardant. Neat neshī / Ottoman ta'lik hand. - Text rubricated. (el-cevāb, titles, overlinings). Catchwords. - Blind-stamped, brown leather binding with flap.

Copied by ("an yad) Aḷmad ibn "Umar; no date $\left(12 / 18^{\text {th }}\right.$ cent.).- Table of contents (f. [4b-5a]). -
Marginal glosses and fetvás by, among others, 'Alì, müfti at Kesrìye (Kastoria); müftĩ of Sis; Muștafá, müftĩ at Ưsküb (Skoplje); 'Abdullāh, müftī at Ergirikasri (Gjinokastër) ; 'Abdüșșamed, müftì at Yanya (Ioannina); 'Atạ'ullāh, müfti at: Yanya; Halīl, müftri at Holumiç (Chlomoutsi); Muhammed, müftī at Kesrìye; 'Alī, müftì at Kula، - f. [398b] contains Tercihh-i beyinat taken from al-Muhịt alBurhānī. - Inserted in an envelope: an original fetvá signed by Ahmed, Müftī...?

Copy II (ISL 169): ff. [4] 280; 270 x 160/210 x $110 \mathrm{~mm}$; 33 lin. - Laid European paper; watermark: crown and grapes. - Clear neshi hand with many elements of icāzet. - Simple golden headpiece; golden single-line rule-borders (f. $1 \mathrm{~b}$ 2a, 241a, 250b, 251a, 260b). - Catchwords. Polychrome text (mes'ele in blue, el-cevāb, chapter-headings, subtitles and overlinings in red). = Some side-heads trimmed.- Modern blue cloth binding, no flap.

Copied by (tahrir; min yad) Darwish Muṣṭáá ibn Muḥammad (colophon in icāzet hand, Fig. 5) in 1189/1775-6. - Table of contents (f. [3b-4b]). - Marginal corrections. Ownership statement (tamallakahu) (f. 1a): Aḥmad Rushdi ibn Muhammad Nūrī, known as Aṭah (?) Nābīzādah.

Ref: $\mathrm{TH}(4), 80$.

\section{3 (ISL 128)}

\section{Fütüvvet üss-şeriff}

Anonymous fütüvvetnāme.

Incipit:

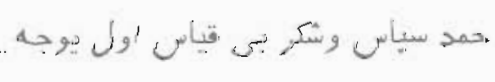

ff. $[47 \mathrm{~b}-51 \mathrm{~b}]$; (for other codicological and paleographical details see no. 36 ).

No colophon ( copied ca. 1267/1850-1, see f. 61a).

$$
14 \text { (ISL, 75) }
$$

\section{Gencīne-ì rãz}

Author: Yaḥyá [Beg Dukākīnzāde] (fl. $1.0 / 16^{\text {th }}$ cent.). - Collection of verses of ethical 
and didactic nature. - Composed in 947/1540-41 (see chronosticon: hูāmūs, on f. 85a).

ff. [1b-85a]; $195 \times 125 / 150 \times 75$ mm.; 17 lin.Laid European paper; watermarks: 1. anchor in circle; trefoil ZM, 2. unidentified. - Clear Ottoman ta'līk hand; (ff. 51-54 supplied by a different hand, neshī).- Single-line rule-borders in red; text in columns. - Catchwords. - Text rubricated. - Blind-stamped brown leather binding with flap.

Copied by (katabahu) Alhmad ibn Shaykh Bayrām in Țirnuwá (Ṭirnova) in 1002/1593. Some omissions in margins.- Four ownership statements with three seals (f. la): 1 . (istașḩ̣abahu) Muștafá Dukkānī, dated (seal) 1180/1766-67, 2. (qad tamalakka) Husayn alDukkānī, 3. (dakhala fi milk) Muhammad Shākir, secretary (kătib) in the Imperial Court (Divān-1 Humāyūn), 4. (intaqala bi-yad) Muhammad Țāhir al-Mawlāwi .

Ref: $\mathrm{TH}(2), 210-211$.

\section{5 (RBD 3)}

[Gülzär-l sevăb]

Author: [l̉brăhim bin Muștafá], known as Nefeszăde (d. 1060/1650). - Treatise on calligraphy, paper and ink. Also known as Tezkiret ül-hyattatin. Titie on f.la: Nefesĩzāde (!) Risālesi.

ff. [30]; $175 \times 110 / 120 \times 70 \mathrm{~mm}$; 11 lin. - Laid European paper; watermark: crown and grapes ...LANGUEDOC. - Clear, partly vocalized neshū hand. - Text rubricated. - Catchwords. - Paper wrapper.

Anonymous copy. - Transcribed (tahrīr) in Rabi ${ }^{*}$ II 1161/1748. - Approximately two first folios wanting.

Ref.: TH(1), 269; TH(4), 523-5; THR, p. 96.

16 (ISL 153)

\section{'Ibretnümānàne}

Anonymous collection of edifying stories (hikāyăt).

Incipit: يدمه عبرت نماناهه خلان مفا واخوان

ff. [30b-47a]; (for other codicological and paleographical details see no. 18).

Anonymous and undated copy (early $12 / 18^{\text {th }}$ cent.). - Main text followed by: 1. Simurg-1 ankā hikāyesi (ff. 47b-49a), 2. two passages from Dürr-i meknün possibly by Ahmed Bicän Yaziciogl (fl. $9^{\text {th }} / 15^{\text {th }}$ ) (ff. 49a-50a) (TH, IV, 333), 3. Gazel-i Sultạn Murād (f. 50b), 4. Münäcät-1 Şeyh Sa'dī, with two seals depicting a lion with a halo (f. $51 \mathrm{~b}$ ).

\section{7 (ISL 138)}

\section{['İmäd üI-İsläm]}

Author: ["Abd al-"Aziz Fārisi]. Translation and commentary by "Abdürrahmōn bin Yũsư el-Aksarāyī (fl. $9 / 15^{\text {th }}$ cent) upon 'Undat al-İslàm, a Persian treatise on the five pillars of Islam ('ibādāt). Title in colophon: "Undat al-İstāun.

ff. [4] 310 (shaved in places) (pp. 675!, supplied later); $195 \times 140 / 115 \times 90$ mm.; 19 lin. - Laid European paper; watermarks: 1 . unidentified coat of arms, 2. three hats, 3. crown-starcrescent; trefoil $A G$. - Neshī hand influenced by other styles. - Catchwords. - Text rubricated. Side-heads (matlab). - European black quarterleather binding.

Copied by (katabahu) Maqșūd ibn Munlā Sayyidī in Jum. I 1069/1659 (f. 305b). Marginal omissions and corrections. - Text preceded by a table of contents (ff. [1b-4]]). f.305b: date of death of 'Ayşe Hâtūn, 1178/1764-5. - f.1 a: prayer, dated 1115/1703-4, Followed by an anonymous short composition on ethics, f. 306a-310b, beginning (after the basmalah and hamdalah): Evvel 'ālem-i faburī...

Ref.: BM, p. 12-13; TSM, I, 235; OM I, p. 265.

$$
18 \text { (ISL 153) }
$$

\section{[Ķanunname]}

Compiler: ['Alı̀ Mü'ezżinzāde, known as 'Aynī 'Alī] (fl. 11/17' cent.). - This work, also known as Kavāniñ-i $\bar{A} l-i$ 'OŞmān der 


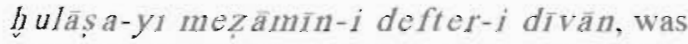
dedicated to Sult an Ahmed I (reg, 1012/16031026/1617) (f.1a).

ff. [1a- 19b]; $205 \times 145 / 160 \times 90$ mm.; 19 lin. Laid European paper: watermark: crown-starcrescent: trefoil BG. - Elegant nesh̆i / icāzet hands. - Catchwords. - Text rubricated. Marginal glosses. - Binding missing.

Anonymous and undated copy (early $12 / 18^{\text {th }}$ cent.). - First leaf missing. - Followed by a description of Istanbul (Kostantinīye) from Aużah ül-mesālik of Mụ̣ammed Sipāhizāde (d. 997/1589, GAL, SII, 44) (f.19b).

Ref.: TH(1), 348; EHB, II, p. 847.

$$
19 \text { (ISL 58) }
$$

Kaşf ül-ḥicāb an vech il-kităb

Author: Yahyá bin "Alī Nev'î (d. 1007/1598-9). - Commentary on Fusus alḩikām (f. la and tail) of Muhyì al-Dìn ibn 'Arabī (d. 638/1240). - Composed in 1002 / 1593-4 (chronosticon: aḩ ar ül-kelām, f. 334a).

ff. [3] 344; $230 \times 160 / 165 \times 100$ mm.; 21 lin. Laid, yellow, tinted and well glazed European paper (except first three folios); watermarks: 1. eagle displayed, 2. lion passant guardant; $\mathrm{AFG}$, 3. three hats. - Elegant neshĩ hand. - Polychrome headpiece; double-line rule-borders.- Text rubricated (qawluhu and overlinings). - Blind and gold-stamped black leather binding, with flap.

Copied by (kitābah, 'an yad) Aḥmad al-Ḥ̣amdi Kümuljunahwī (Gümülcünevĩ) in 1244/1.828-9 (colophon in icāzet hand, Fig. 4), - Table of contents (f. [2b]). - Marginal glosses and corrections.

Ref:: TSM, I, 157-159; GAL, S1, 794.

\section{0 (RBD 4)}

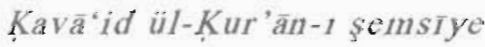

Short, anonymous composition on rules for the recitation (tecvīd) of the Qur'ān. Main part of the text divided into ten chapters (f. 6a) such as: 1. merātib ül-ahkām in-nūn is-sākine, 2.merātib- i medler, 3.merātib-i maksūre... (appears to be different from TSM, I, 7 and THB, 12a).

Incipit: اعلم يتنى بلكل كم قران تجويد ايله..

ff. $21 ; 195 \times 125 / 165 \times 70$ mm.; 27 lin. - Laid European paper: watermarks: 1. crown-starcrescent; trefoil $\mathrm{AG}$; trefoil $\mathrm{bV}, 2$. anchor in circle. - Ottoman ta lịk hand.- Text rubricated.Catchwords.- Marbled paper half-vellum binding.

Anonymous and undated copy (late $11 / 17^{\text {th }}$ or early $18^{\text {ih }}$ cent.). - No preface. - Presented to the Library by Lady Roddick. - Bookplate: In Memoriam Peter Whiteford Redpath B.Sc. Jocelyn Clifford Redpath, B.C.L.

$$
21 \text { (ISL 74) }
$$

\section{Kitāb ün-necāt}

Author: Ismá'il Hakki $\overline{1}$ [Celveti]] elBurusavī (d. 1137/1725). - Handbook for Sufì adepts. - Composed in Dhū al-Hijjjah 1131 1 1.791. (chronosticon: ḩatm-t kelām).

ff. [125]; $230 \times 150 / 160 \times 105$ mm.; 25 lin. Wove European paper; no watermark.- Neat neshī hand.- Single-line rule-borders.Overlinings, in dark-red.- Side-heads.Catchwords. - Plain, red leather binding with flap (marbled paper doublures).

Copied by ('an yad) Ahmmad ibn Ạ̣mad alAnqarawi known as Qarah (Kara) Shaykhzādah, in the reign of Sult an Abdülaziz, 1288/1871, in aí-Qusț anținìyah (Kosțanținiye). - Marginal corrections. - End leaves (thick paper) with a printed statement to the effect that this paper is to be used for wakf purposes.

Ref.: TH(2), 46; EHB, II, p. 905.

$22($ OL $389 / 18)$

\section{$[K i t a \bar{b}-1, t, b b]$}

Anonymous medical treatise containing such chapters as : fă'ida li-ḥaraḳān il-bevl (p. 28); fầ'ida lil-gișāve ve'l-humre (p. 29); șıfăt-1 ma cū n (p. 30); șfăt-1 haubb-1 sultān (p. 30) . 
pp. $28-63 ; 225 \times 160 / 170 \times 100 \mathrm{~mm}$.; 25 lin.. Laid European paper; watermark: three crescents with human profiles. - Clear neshi hand. - Catchwords. - Text rubricated. - Red cloth binding.

Anonymous and undated copy (early $13 / 19^{\text {th }}$ cent.). - Incomplete at beginning and end.Preceded by $M a j m u{ }^{*}[f i a l-t i b b]$ (Arabic) (see AMM, 117).

$23($ OL 389/7)

$[K i t a b-1+1 b b]$

Anonymous medical treatise.

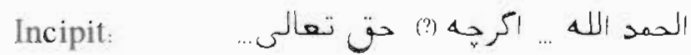

ff. [61b-70b]. - Laid paper. - Ottoman ta'lik hand. - Ink offset. - Water-stained. - Rubrics not supplied. - Catchwords.- For other codicological details see no. 24.

Incomplete (13/19 ${ }^{\text {th }}$ century).- Followed by (f. $71 \mathrm{a}-87 \mathrm{~b}$ ) fragments from various unidentified medical texts.

$$
24 \text { (OL 389/7) }
$$

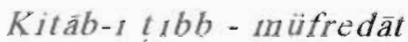

Author: Şāhīn Bey bin. Murād (?). - Book of simple remedies (herbal) arranged alphabetically beginning with bāb-i evvel ìn kamcā (?)

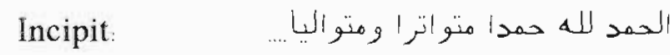

ff. $[1 \mathrm{~b}-32 \mathrm{~b}] ; 200 \times 140 / 180 \times 110-125 \mathrm{~mm}$; 17-21 lin. - Laid European paper; watermark invisible. - Neshi / Ottoman ta'lik hand. Catchwords. - Text rubricated. - Badly waterstained.- Modem style binding with raised bands and title in gold on the spine in Arabic (Mufrad̄at fì al-țibb).

Incomplete at end (probably one or several folios missing, $11 / 17^{\text {th }}$ cent). - Marginal glosses and corrections, some shaved. - Bookplates: 1.Dr. M. Meyerhof (in Arabic), 2. Casey A. Wood. - Main text followed by (ff.33a-58a and 7 la-b) unidentified fragments from a medical treatise divided into fusul from portion of second fașl to thirty seventh fașl (second faṣl: fasl-1 sersām; third: fașl-ı şabbāt; fourth: faṣl-1 seher; fifth: fașl-1 misyān...).

$$
25 \text { (ISL 59) }
$$

Menăkib-1 Seyh Şa bān Veli

Author: "Ömer el-Fu'āī̄ Efendi (d. 1046/1636-7). - Hagiography of Şeyh Sa'bān Veli composed in $1017 / 1608-9$.

ff. $[86,+4$ blanks]; $220 \times 135 / 150 \times 70 \mathrm{~mm}$; 19 lin. - Laid European paper, watermarks: 1 three hats; FFA, 2. coat of arms (lion rampant); (iFA.- Ottoman ta'lik hand with many elements of neshir. - Simple but elegant golden headpiece; single-line red rule-borders.- Catchwords.- Text rubricated (overlinings, keywords, quotations).Dark red leather binding with golden borders and center-pieces (flowering plant), flap missing,

Anonymous copy; dated 1145/1732-3. Followed by (f. 86a-b) a quotation from a work of Muhyī al-Dīn ibn 'Arabī (d. 638/1240).

Ref.: TGK, I, 163-164.

26 (ISL 62)

\section{Menazil ül- 'àrifin}

Author: [Muḥammad al-Ghazzāīi] (d. 505/1111). - Translated extract with a commentary from $K \bar{n} m \bar{i} y a{ }^{\prime}, a l-s a^{\circ} a d a h$ (GAL, I, 540, no. 29) by Şemsediīn es-Sivàisi (d. $1006 / 1597)$.

ff. $[1 b-63 b] ; 235 \times 160 / 175 \times 95$ mm.; 13 lin.Laid, light-brown tinted paper; watermark: lion passant guardant; A.G. - Clear, mostly vocalized neshi hand (Fig. 6). - Simple golden headpiece; rule-borders filled with gold (ff.1b-2a) - Text rubricated (key words, quotations). - Marbled paper covered boards with flap.

Anonymous copy, transcribed probably by Muhammad Țāhir Rūh̄̄, pupil of Mụhammad alWasti, ca. 1240/1824-5 (f. 73b), - Followed by: 1. (f. 64a-66a) Hadith enumerating names of the prophets, 2. (f. 66b-70b) Bahs ül-esmà' il-hüsnà, 3. (f. 71 a-73b) Bad' al-amālī (in Arabic) by Sirāj al-Dīn 'Alī ibn 'Uthmān al-Ūshì (fl.569/1 1.73), see GAL, I, 552; SI, 764. 
Ref: TH(2), 94-95.

\section{7 (ISL 148)}

Meslek üt-tălibinn ve't-'abidin [ve\% văsilfin]

Author: "Abdullāh Simāvì, known as liāhī Efendi $(896 / 1490-1$, or $893 / 1488$, f. 1a). Handbook for sufi novices.

ff. [1] $146 ; 210 \times 130 / 145 \times 75$ mm; 15 lin. Laid, buff tinted European paper; watermark: coat of arms (eagle displayed) GIORO MAGNANI; AL MASSO. - Clear neshi hand. Simple golden headpiece; single-line ruleborders.- Text rubricated (keywords, overlinings). - Brown leather binding with flap and gold-stamped borders.

Anonymous and undated copy (copied before 1283/ 1866-7, f. la).- Ownership note: 'Ali Kamāl ibnn 'Alí al-Murtaḍa iḅn al-Hạjij Husayn, dated 1339/1920-1 (i. 146b).

Ref: $\operatorname{TH}(2), 58-63$.

\section{8 (ISL 75)}

\section{Miftah-1 cennet}

Author: [Ferid Ahmed Bey (Paşa)] (d. 990/15867). - Short anonymous treatise on religious ethics in 8 sections (bāb) without preface.

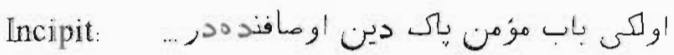

ff. [86a-88b]; (for other codicological and paleographical details see no. 14) .

Anonymous and undated copy (ca. 1002/1593, see no. 14).

Ref.: OM, III, p. 364; EHB, III, p. 1144

\section{9 (ISL 12)}

\section{Minhăc üI- İslām}

Author: Muhammed bin Isma'il (fl. 923/1517).- Manual of religious observances ('ibādāt).- Composed (chronosticon: zuhrr-i kavĩi) in $923 / 1517$ (f. 5a, lin. 11).

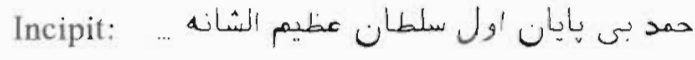

ff. [2] $250 ; 300 \times 170 / 250 \times 130$ mm.; 23 lin. Laid European paper; watermarks: 1. scissors, 2. anchor in circle, 3. three hats; trefoil SS (ff. 150159 supplied later).- Elegant, partly vocalized neshū hand. - Some lines in bold. - Catchwords. Foliation: verso of folios. - Text rubricated. Paper covered boards; flap missing.

Anonymous copy, transcribed (taswīd, 'an yad) in Jumādá I 966/ 1559 (f. 250b). - Marginal glosses. - Text collated (omissions, corrections, etc.).- Fonmer owner (istașhabahu) Dārnădzādah Fayḍ Allāh (f. [2a]), - Invocations: 1. yā kebikec yā hạì (f. [2a]), 2. yā Fettāh yā 'Alìm (above besmele) (f. lb). - f. [1 a] contains a hadith relating to prayer on the authority of Abu Bakr.

Ref.: TGK, I, 73; TH(4), 32 (attributed to 'Abdullāh bin Ismā'îl, different incipit).

$$
30 \text { (ISL 63) }
$$

\section{Netā'ic ïi-fünān ve mehāsīn-i mütūn}

Author: [Yahyá bin 'Alī el-Nev'i]] (d.1007/1598-9).- Encyclopedia of twelve disciplines dedicated to Sultan Murad III (reg. 982/1574-1003/1595).

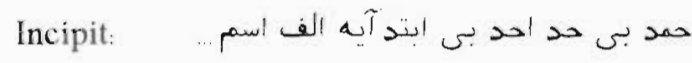

ff. [79]; $265 \times 185 / 220 \times 140 \mathrm{~mm}$; 21 lin. Laid European paper; watermark: PICARDO; BP. - Legible rik" a kurması hand. - Single-line rule-borders. - Catchwords. - Text heavily rubricated (chapter headings, overlinings, diagrams, etc.). - Marbled paper covered boards; no flap.

Anonymous copy, transcribed in Shawwāl 1247/1832. (f. 77b). - Some marginal glosses. Side-heads. - Main text followed by magical formulae (f. 78a). - Inserted in an envelope: six short prayers on tiny scraps of paper and a letter informing the local meclis of Kalburca of the arrival of a preacher (wā' 'iz) dated 1303/1885-6, with the seal of Hasan Seză'y in Turkish.

Ref: TH(1), 372; NE. 


$$
31 \text { (ISL 50) }
$$

Pendnäme, also known as Delil-i budalāa

Author: Kaygusuz [A bdāl] (fl. $9 / 15^{\text {th }}$ cent.). - Sufi treatise containing edifying stories.

ff. $\quad[1 \mathrm{~b}-22 \mathrm{a}] ; 240 \times 175 / 190 \times 120 \mathrm{~mm}$; 17 lin.- Laid European paper; watermarks: 1. lion passant guardant, 2. coat of arms (lion rampant).- Neshī / Ottoman rik'a hand. Catchwords. - Text rubricated. - Leather and marbled- paper- covered boards; no flap.

Anonymous and undated copy (ca. 1263/18456, see no. 34). - Donation statement: gift from Hüseyin Baba of Birecik who was post-nişin of Bektaşi Hูānkāhı to Hasan Hulkị Riżā. - Inserted in an envelope: 'Arsh-i a lá, cosmological chart $(520 \times 375 \mathrm{~mm}$.), written on laid European paper; watermark: crescent with human profile.

Ref: $\operatorname{TH}(2), 86$; TH(3), 84.

$$
32(\text { OL } 389 / 7)
$$

Risāle-i manzūne fì illm-i tibb

Author: most probably Nidā' I (d. after 975/1567-8), - Medical didactic poem.Composed in the time of Sultan Selim II (reg. 974/1566-982/1574).

Incipit:

$$
\begin{aligned}
& \text { الهى حكمت اسمى هحتشم سن }
\end{aligned}
$$

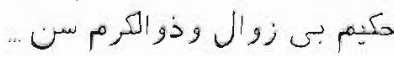

ff, [88a-141b]. - Watermark: crown-starcrescent. - Clear neshi hand. - Rubrication. Badly water-stained.- For other codicological details see no, 24 .

Anonymous and undated copy (early $12 / 18^{\text {th }}$ cent).

Ref: TH(3), 203; TH(4), 400; TH(5), 186 (same explicits but different incipits).

$$
33 \text { (ISL 128) }
$$

[Risăle-i must talahăt-i șüfye]

Anonymous treatise on sufi discourse.

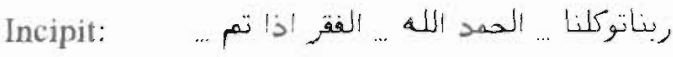

ff. [41a-44b]; (for other codicological and paleographical details see no. 36).

No colophon. - Copied ca. 1267/1850-1 (f. 61a).

$$
34 \text { (ISL 50) }
$$

[Risāle-i ṣufiye]

Anonymous treatise in the form of a conversation between a pupil and his master.

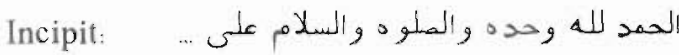

ff. [236b-344b]; (for other codicological and paleographical details see no. 31 ).

Copied (katabahu) in 1263/1845-6 by Șādiq, follower of (haq-pāy-i) Naqshaband Muhammad Bahà' al-Dīn.

35 (ISL 128)

Risāle-i şerîf

Anonymous sufi commentary on a hadith: $\quad ن$

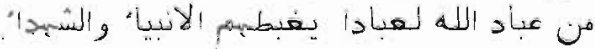

Incipit:

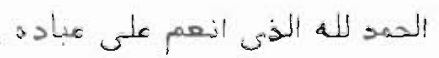

ff. [44b-47b]; (for other codicological and paleographical details see no. 36 ).

No colophon. - Copied ca. 1267/1850-1 (1. 61a).

$$
36(1 S L, 128)
$$

Risāle-i vahtet ül-vucūd

Author: [Muhyi al-Din Muhammad ibn 'Arabil (d. 638/1240). - Translation of Risälah fi al-ahadiyah, also known as Risălat alahadiyah, Risālat al-wujudìyah and Risāiah fi sharh tna'ná qawl al-nabi: Inan "arafa natsalt faqad 'arafa rabbah, possibly by Hüseyin Hüsnü bin Ismài îl.

Incipit:

ff. [1b-14b]; $240 \times 170 / 180 \times 120 \mathrm{~mm} . ; 15$ lin.Laid European paper; watermarks: 1. eagle 
displayed, 2. coat of arms (lion rampant). - Clear neshri hand. - Catchwords. - Overlinings.Marbled-paper-covered boards; no flap.

No colophon. - Copied ca. 1267/1850-1. (f. 61a).

Ref.: HC, I, 13; II, 621; GAL, I, 579 (no. 104); SI, 798 (no, 108).

$$
37 \text { (ISL, 128) }
$$

Risāle-i vālideyn - te’dīb ülmütemerridin

Author: $\mid$ Awh ad al-Dīn 'Abd al-Ahad alNūrì] (d. 1061/1651). - Anonymous translation of the author's Ta'dib al-mutamarridin fi haqq al-abawayn.

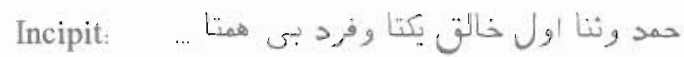

ff. [15b-33b]; (for other codicological and paleographical details see no. 36).

No colophon. - Copied ca. 1267/1850-1 (f. 61a).

Ref:: OM, I, p. 121; GAL, II, 591; SII, 662.

$$
38 \text { (ISL 153) }
$$

Risăle-i vazịfe-h̆̄ărān merātib-i bendegăn-i $\bar{A} l-i \cdot O \operatorname{sinān}$

Author: "Alī Mü'ezzinzāde, known as 'Ayn-i "Alr. - Treatise on Ottoman bureaucracy and statecraft.

ff. [20a-30a]; (for other codicological and paleographical details see no, 18),

Anonymous and undated copy (early $12 / 18^{\text {th }}$ cent,).

Ref:: GSO, p. 141; EHB, IV, p. 1482; BN, 128, $885,1092$.

$$
39 \text { (ISL 128) }
$$

[Su'àl ve cevāb]

Anonymous questions and answers relating to mysticism.

Incipit: الحمد لله الذ لم يتخذولدا وما توفيقى... ff. [34a-41a]; (for other codicological and paleographical details see no. 36 ).

No colophon. - Copied ca. 1267/1850-1 (f. 61 a).

$$
40 \text { (ISL 128) }
$$

[Şerhli-i ebyāt-1 Yünus Emre]

Anonymous commentary on nine verses from the Divān of Yūnus Emre (1l. $7 / 14^{\text {th }}$ cent.). Composed in 1117/1705-6.

ff. [52a-61a]; (for other codicological and paleographical details see no. 36).

Dated $1267 /$ 1850-1. - Followed by 29 verses from Dĩvān of Seyyid 'İmādüddīn Nesīmī (d. 821/1418, see İA, IX).

Ref:: YE, p. 209-222.

$$
41 \text { (ISL 132) }
$$

Şerḥ-i Mültaḳál-ebḥur

Author: [Muḥammed Mevkúfātī] (d. 1065/1654). - Translation of and commentary on Multaqá al-abhur, an Arabic manual of Hianafit law by Ibrāhīm al-Halabĩ (d. 956/1549) (GAL, II, 432; GAL, S II, 642), - Identified by a later hand (dated Safar 1291/1874) as Mültaká tercemesi by Hamdi Efendi (see fly-leaf and tail).

ff. [3] 686; $205 \times 150 / 160 \times 100$ mm.; 21 lin. Glazed laid European paper; watermarks: 1. crown and grapes, 2. eagle displayed. - Clear neshyi hand. - Some quires (10 folios each) numbered. - Simple golden headpiece; doubleline rule-borders. -Irregular catchwords. - Text rubricated (overlinings). - Water-stained (ff. 110) and wormed. - Dark-brown leather binding with flap; gold-stamped borders and onlaid center-pieces.

Copied (harrarahu) in Dhū al-Hijjah 1188/ 1775 by Ismā'il, Shaykh of the reciters (alqurrā') at the mosque of Tubkhānah (Țophāne), Istanbul and a pupil of Abu Muhammad "Abd Allāh ibn Muhammad, known as Yuusuf Afandizādah (Efendizāde) (f. 686a). - Table of contents (ff. 1-3). - Clean copy. 
Ref.: TH(4), 66; EHB, III, p. 1261.

$$
42 \text { (ISL, 75) }
$$

\section{Ta'birr-i düiş}

Short anonymous treatise containing 28 rules for the interpretation of dreams.

Incipit: .بو دوش تعبيراتى مظلمبم مختصر فايدهلو...

ff. [89a-b]; (for other codicological and paleographical details see no. 14).

Anonymous and undated copy (ca. 1002/1593, see no. 14). - Followed by: 1. ff. $90 \mathrm{~b}-91$ b short text containing two dẩires by Tatar Îbrāhīm Efendi on cosmology, 2. ff. 92a-96a various verses, some by Bākī Efendi, 3. ff. 97b-99b story from the life of Prophet Muhammad ending with Du 'â' 'ul-istighfar and a number of verses.

$$
43 \text { (ISL 141) }
$$

\section{Terceme-i nis āb ül-iht tisāb}

Author: Sirajj al-Din 'Umar ibn Muhammad ibn 'Awḍ al-Sha'mī alSunnāmi (fl. 993/1585). - Translation and commentary by 'Alī Cevherī Efendi, known as 'Alì bin Balī (d. 991/1583), on Nisāb al-ịhtisāb (GAL, II, 403; SII, 427), being a treatise on moral regulations in society and the market. According to a note on f.la it was translated (tārihh-i terceme) in 969/1561-2.

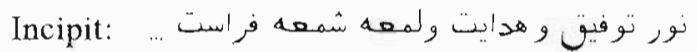
ff. [81] (original foliation 1-14) ; 190 x 130/155 x 80 mm.; 21 lin. - Laid European paper; watermark: paschal lamb; trefoil PP. - Clear neshĩ hand. - Simple golden headpiece; golden double-line rule-borders. - Catchwords. - Text rubricated (overlinings, titles, keywords, quotations). - Side-heads in red. - Decorated paper-covered-boards; no flap.

Anonymous and undated copy (12/18th cent.). Clean copy.

Ref.: OM, III, p. 85.

$$
44 \text { (ISL 61) }
$$

Terceme-i Risāle-i Kudsĩye
Translation and commentary by 'Abdullāh Şalăhī 'Uşşākị (d. 1197/1782-3) on an anonymous al-Risälah al-Qudsĩyah, completed in 1180/1766-7 (chronosticon: zafer), containing sayings (kalimāt) of Bahă al-Din Muhammad Naqshaband al-Bukhārn (d. 791/1389), known as Muhammad Părsā (GAL, SII, 282).

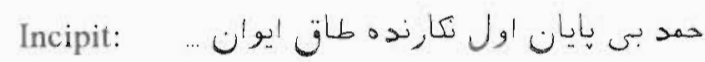

ff. [50] (last folio blank); $197 \times 130 / 135 \times 80$ mm.; 15 lin. - Laid, light brown tinted paper; watermarks: 1. coat of arms (lion rampant), 2. crown and grapes, 3. eagle displayed FG. Elegant neshī hand (Fig. 2). - Illuminated headpiece; single-line red rule-borders. - Text rubricated (overlinings). - Side-heads (matlab). Red leather binding with flap and gilt borders and center-pieces.

Anonymous and undated copy (early $12 / 18^{\text {th }}$ cent.). - Some marginal glosses. - Ownership statement (istashabahu) (f. la): Sharīf Ahmad Muhỹi al-Dìn al-Qādirī, resident (sâkīn) in Tubkhānah (Tophāne), Istanbul at Takiyah Qàdirikhānah (Tekye-i Kãdirihāne) with a seal, dated 1286/ 1869-70: Post-nişin-i. Ķădirihuāne, 1286.

Ref. OM, I, p. 105; EHB, IV, p. 1477.

45 (ISL, 130)

\section{Tezkiret ül-evliya"}

Author: Farīd al-Dín Muhammad al-Atta ar (d. 637/1239-40). - Translation of the Persian dictionary of sufi personalities Tazkirat al-awliyà ' by Hüseyin Enīsī (not mentioned in PFA).

Incipit: الحمد لله رب العالمين والصلوه و السدلام ...

ff. [232]; $227 \times 135 / 140 \times 80$ mm.; 15 lin. Laid European paper; watermarks: 1. three hats, 2. three crescents $\mathrm{A}$. - Neshì hand changing in some places to Ottoman ta'lik.- Text rubricated. - Side-heads (matlab). - Brown paper-covered boards; flap missing.

Copied by (ladá !) Muhammad, known as Jawushzàdah (Çavuşzāde), the Qạdī of the district (bi-qaḍa '/każà') of Qarahyaqah 
(Karayaka) in Safar $1143 / 1730$ (f. 232a). Several seals (some erased) on f. Ia and $231 \mathrm{~b}-$ 232a.

$$
46 \text { (ISL, 105) }
$$

Velāyetnāmè-i Hăcım Sultānn

Author: [Uzun Firdevsi, known as Firdevsi-i Tavil]: - At head of title:

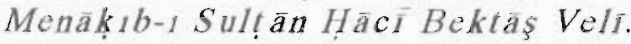

ff. $[54] ; 210 \times 140 / 150 \times 80 \mathrm{~mm} ; 13$ lin. - Buff wove paper; no watermark. - Elegant rik'a hand (Fig. 7). - Catchwords. - Text rubricated. Western style half-leather binding.

Anonymous and undated copy (late $13 / 19^{\text {th }}$ or early $20^{\text {th }}$ cent.). - Former owner: Vakf-1 Dergäh-i Karaağac.

Ref:: TA, XVIII., p. 284; VH.

$$
47 \text { (ISL 118) }
$$

Velayetnāme-i ... Haci Bektās Velī elHorāsāni

Anonymous hagiography of Hacr. Bektaş.

pp. [8] 458; $220 \times 160 / 170 \times 90 \mathrm{~mm}$; 19 lin. Wove and laid (pp. 370-458) European paper; watermarks (laid paper): 1. eagle displayed TSG, 2. coat of arms (lion rampant). - Rik'a kurmasi hand. - Catchwords. - Text rubricated. Orange paper covered boards; flap missing.

Copied by (harrarahu) Husayn Tawfiq, son of "Abd Alläh Baghdādī, Pust-nishīn (Post-nişin) of Q as a bat Mustafá Bāshã (Kașaba-yı Muștafá Paşa), Dhū al-Hijjah 1270/1854, - Main text preceded by table of contents. - Marginal glosses in pencil.

Ref.: TH(4), 151; EHB, V, p. 2015.

48 (ISL 170)

\section{Zeyl-i takvîm üt-tevārih}

Author: Sem'dānizäde Findikli Süleymān Efendi (d. 1193/1779). - Short version of his Mür ${ }^{*} \bar{I}$ üt-tevarih .

ff. 139 (European figures) ; $220 \times 145 / 180 \times$ $130 \mathrm{~mm}$; $23 \mathrm{lin}$ - Modern wove ruled paper. Neat Ottoman rik'a hand. - Anopistograph. Text rubricated. - European style black quarter leather binding.

Copied in September 1929 by 'Oşmān Ferid Bey (f. 139a). - Corrected (tashịh) copy (f. 139a).

Ref.: SF.

\section{Notes}

1 Gacek, Adam. Arabic manuscripts in the libraries of McGill University. Union catalogue. Montreal, McGilll University Libraries, 1991 (Fontanus Monograph Series I); idem. "The diploma of the Egyptian calligrapher Hasan alRushdi", Manuscripts of the Middle East, 4 (1989): 44-55; idem. "Arabic calligraphy and the "Herbal' of al-Ghâfiqî: a survey of Arabic manuscripts at Mct.jill University", Fontanus, 2
(1989): 37-53; idem. "Early Qu'ranic fragments", Fontanus, 3 (1990): 45-64; idemı. "A collection of Qur'anic codices", Fontanus, 4 (1991): 35-53.

2 Bimbaum, Eleazar. "The transliteration of Ottoman Turkish for library and general purposes", Journal of the American Oriental Society, 87 (1967): 122-156. 



\section{Concordance}

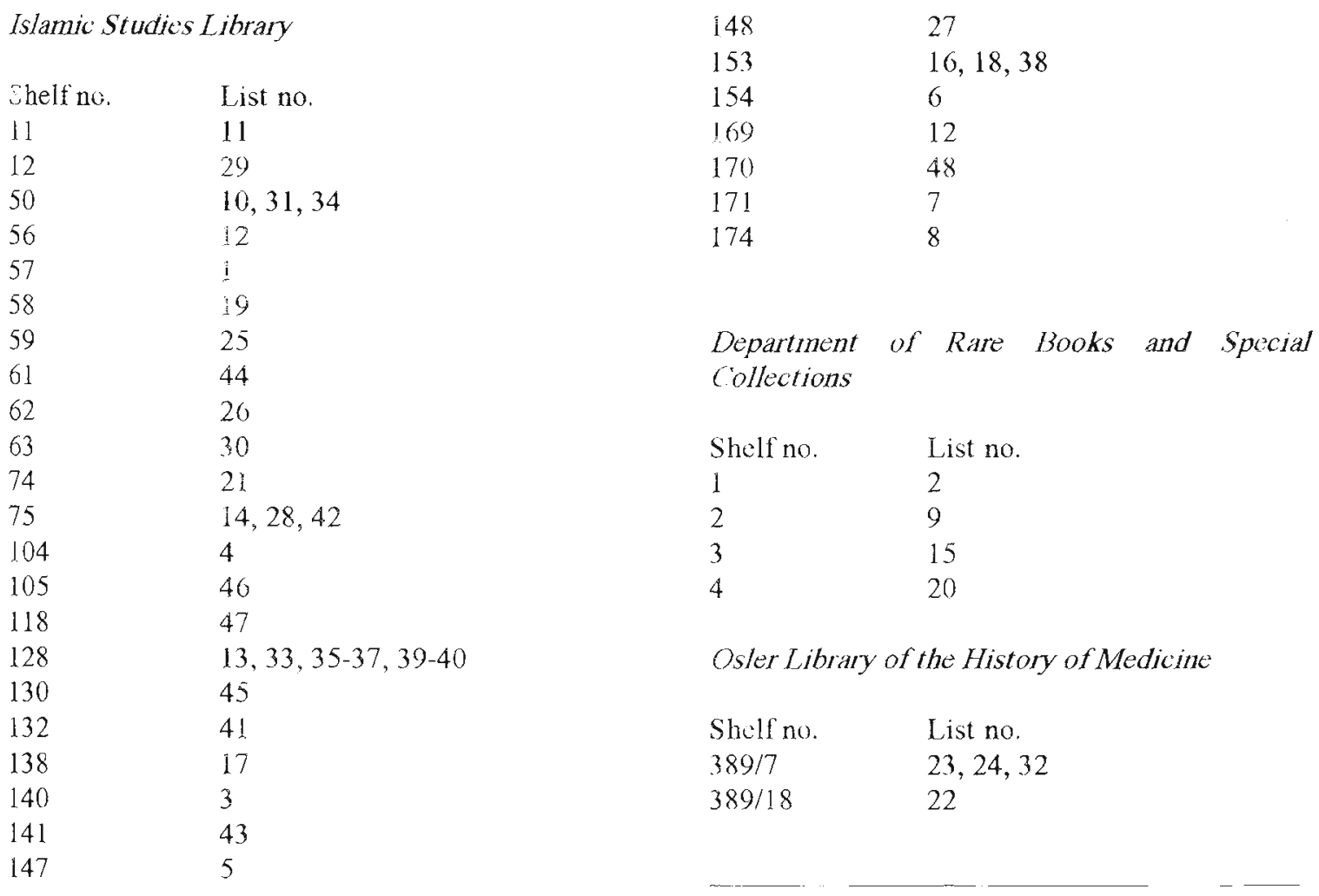



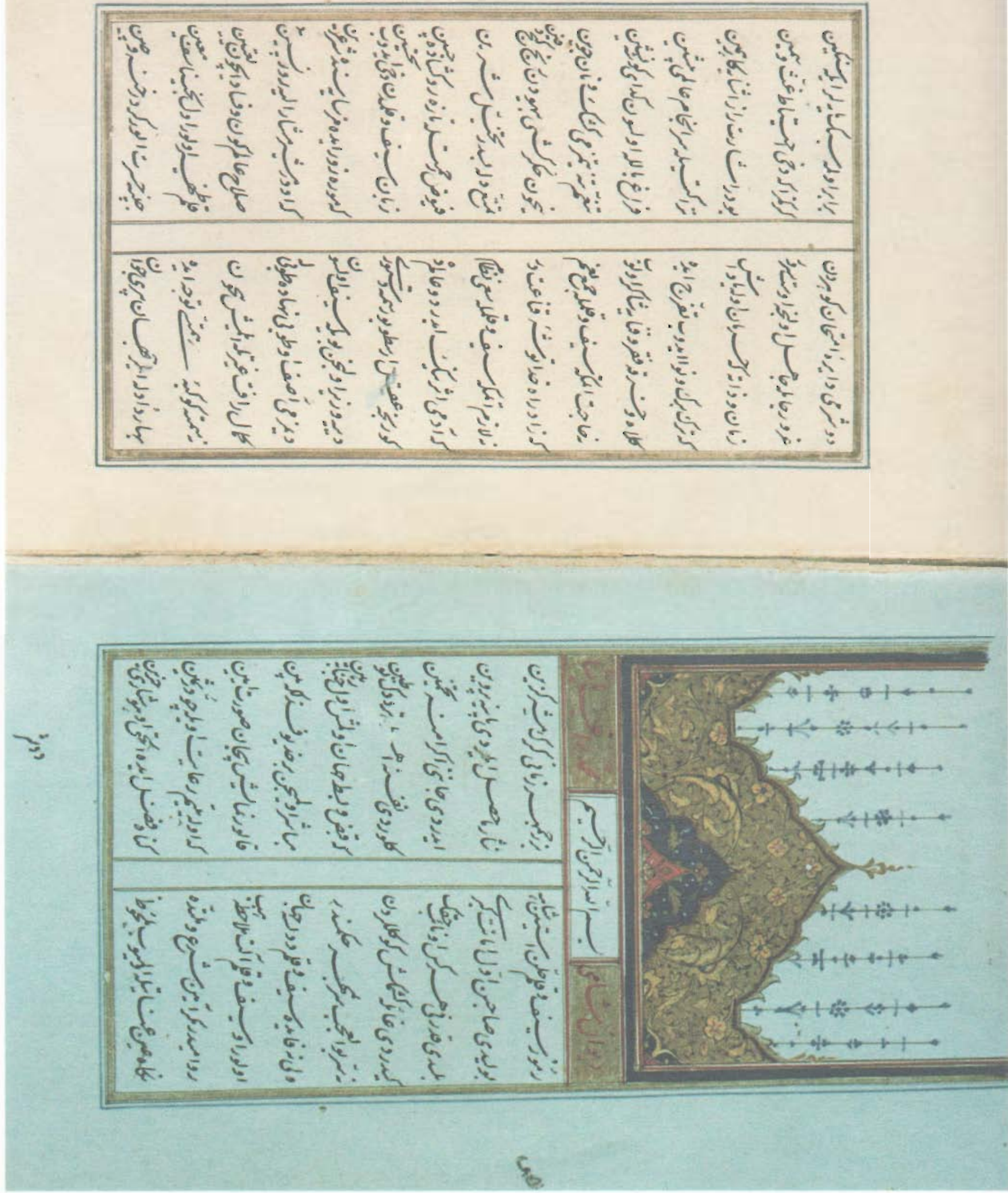


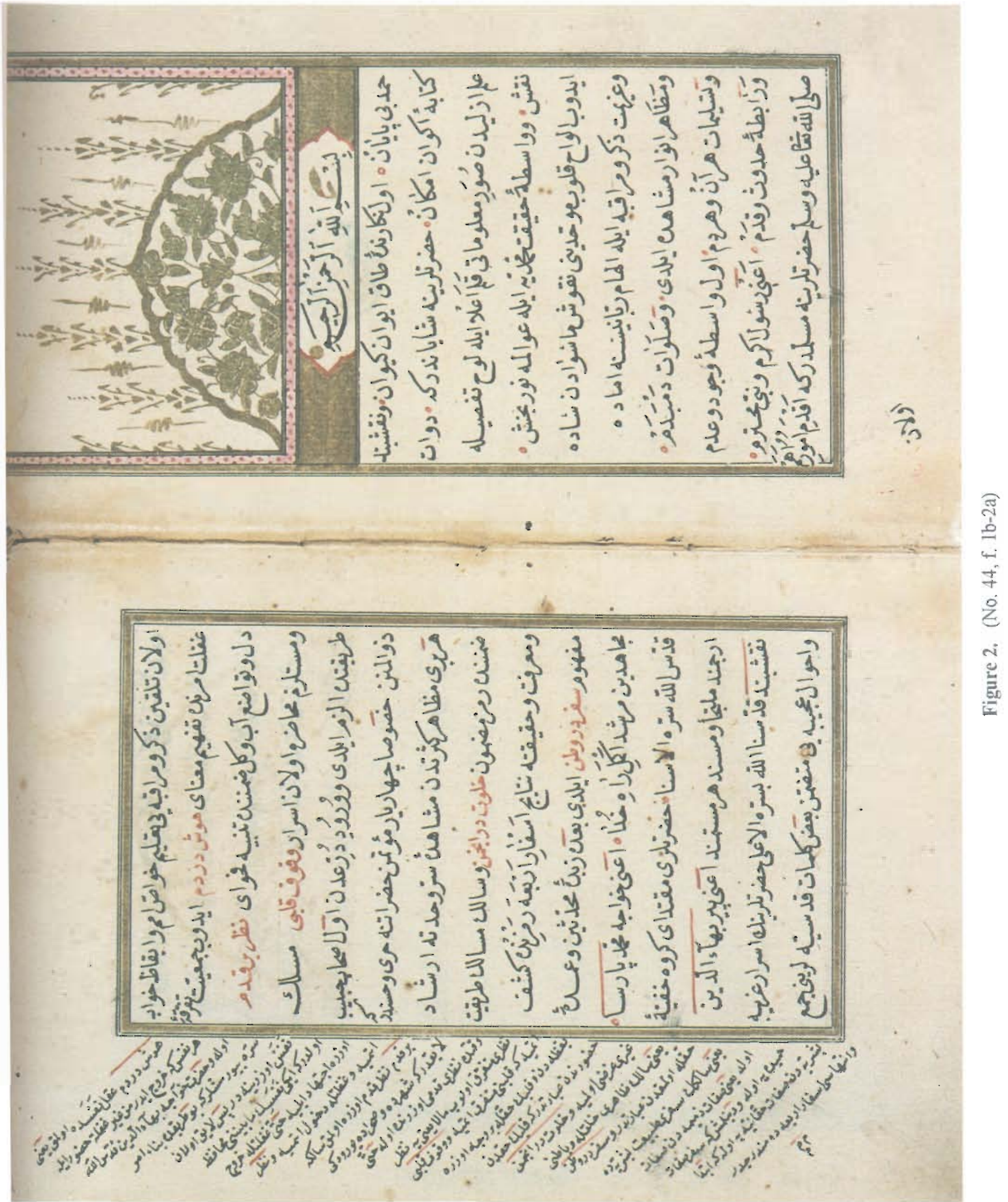




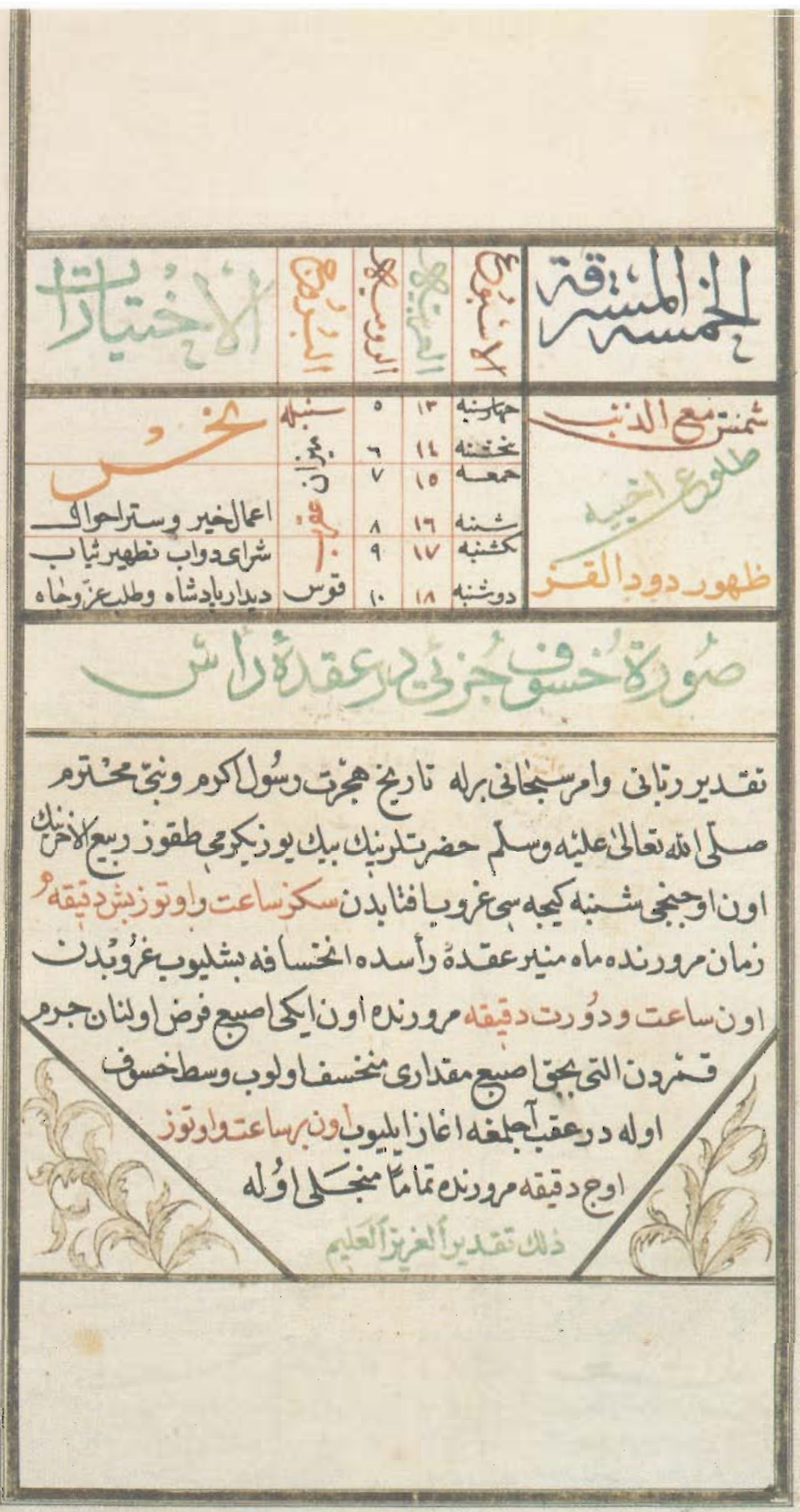

Figure 3. (No. 2, f. 8b) 


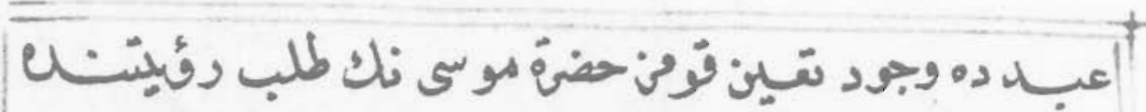

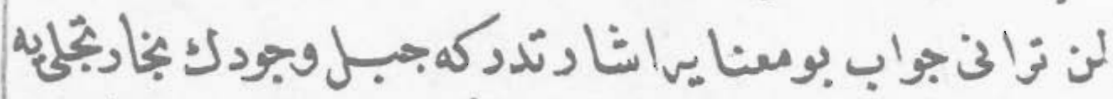

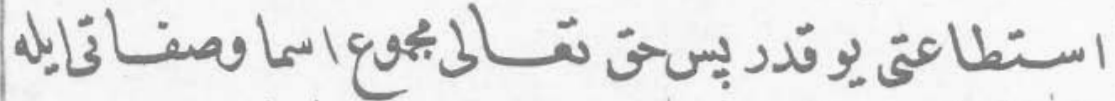

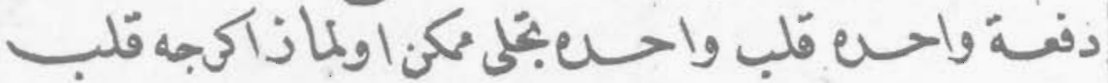

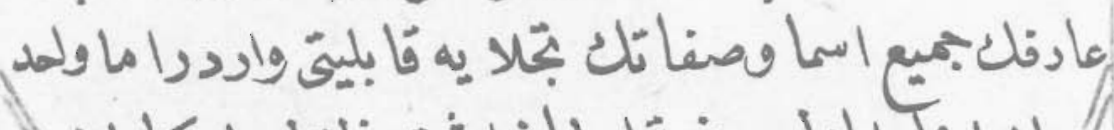

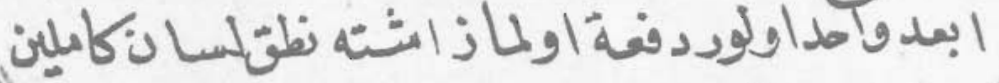

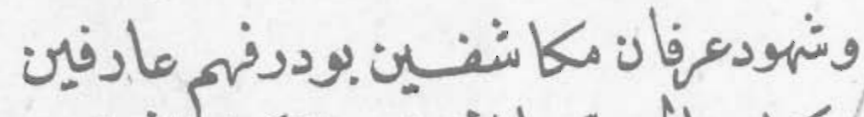

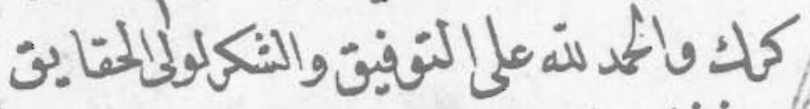

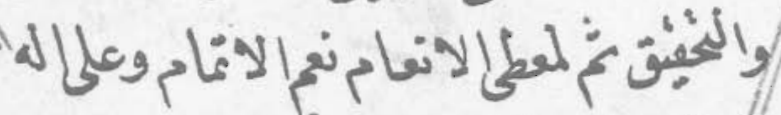

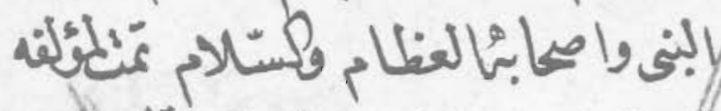

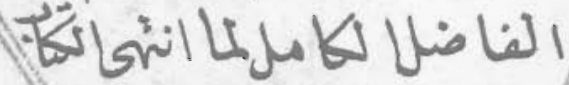

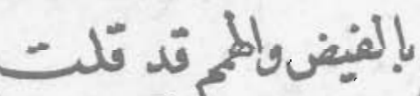

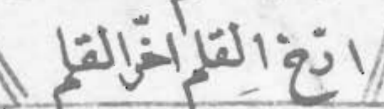

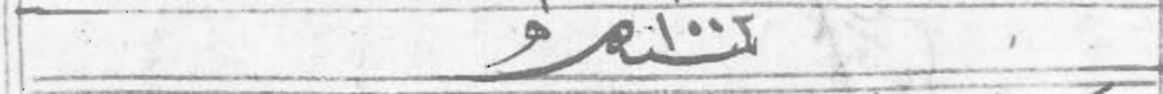

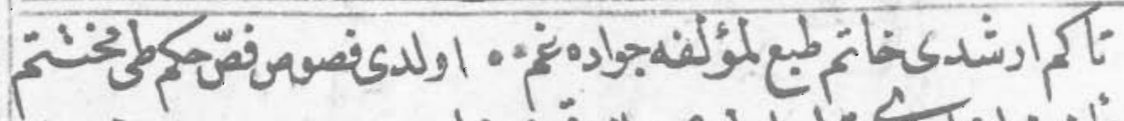

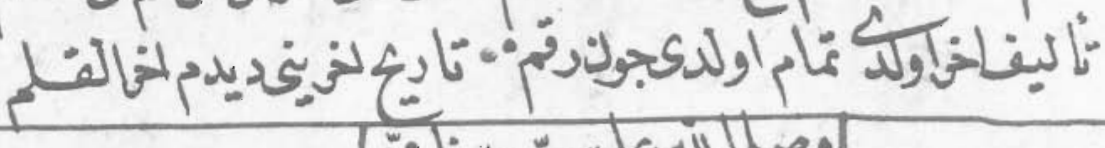

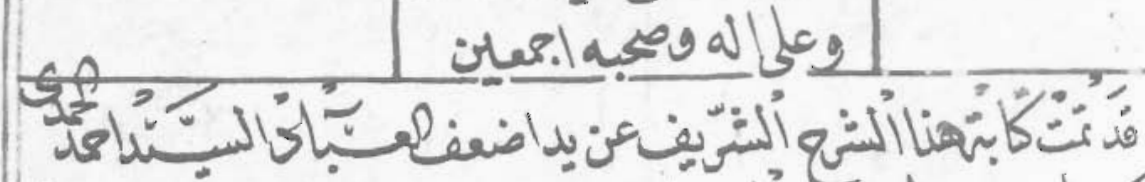

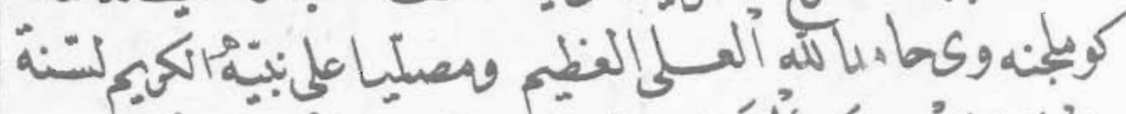

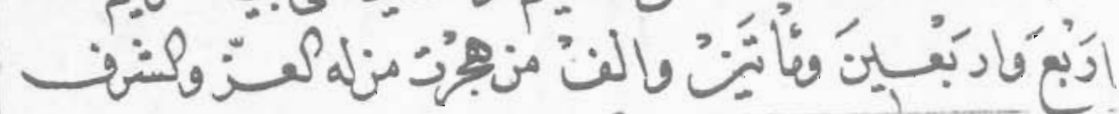

Figure 4. (No. 19, f. 344a) 


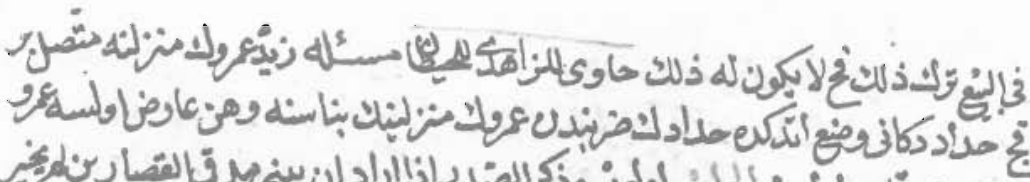

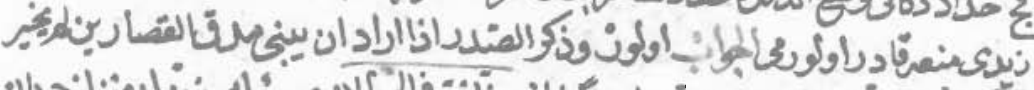

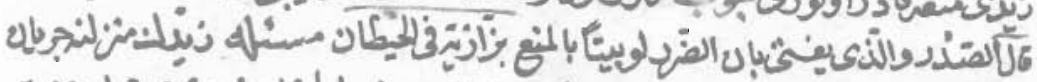

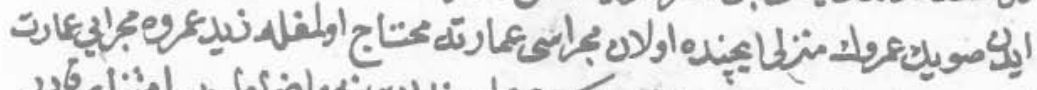

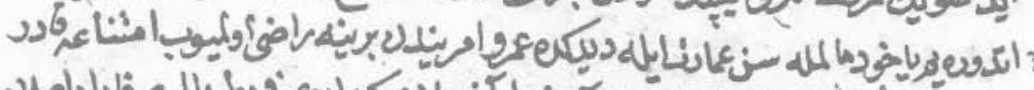

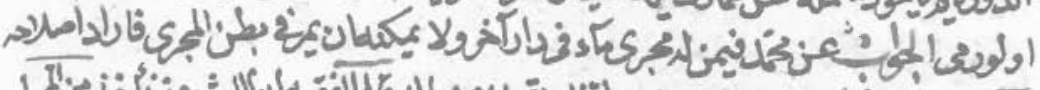

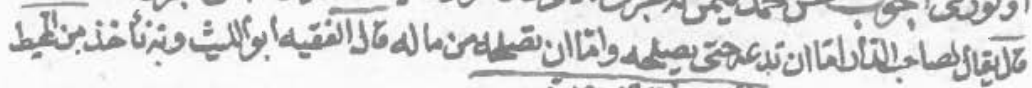

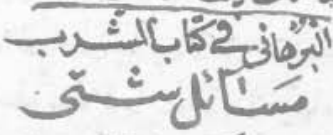

s

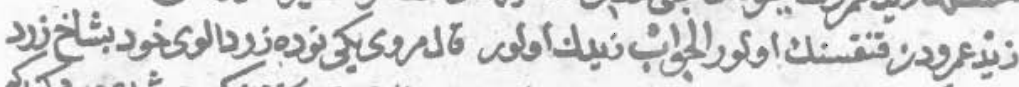

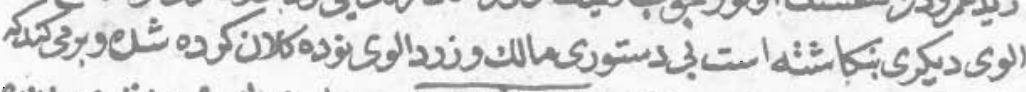

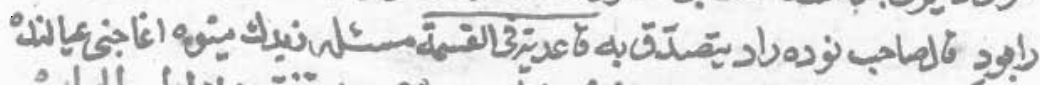

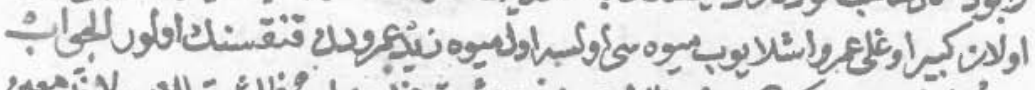

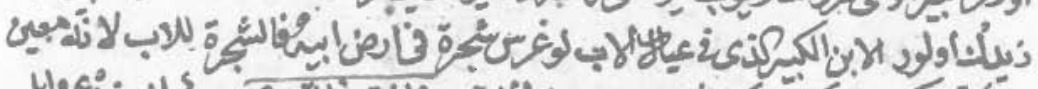

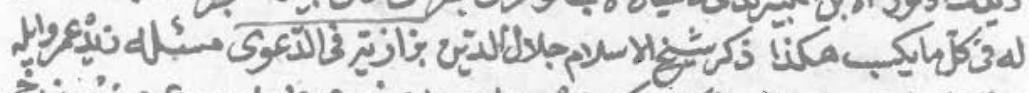

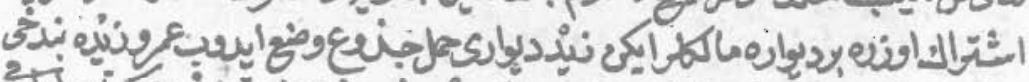

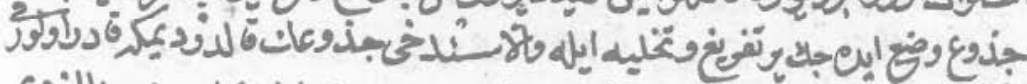

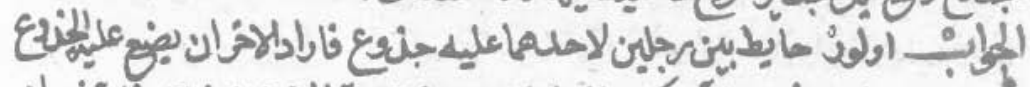

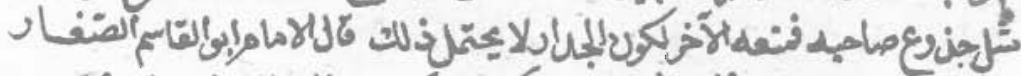

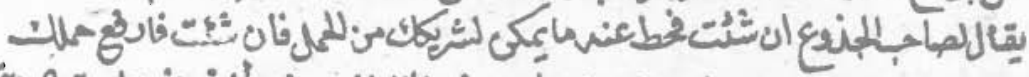

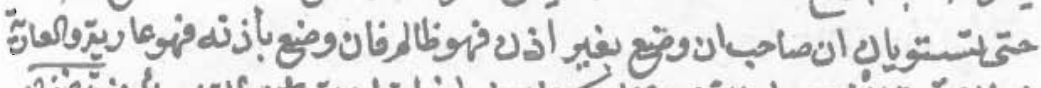

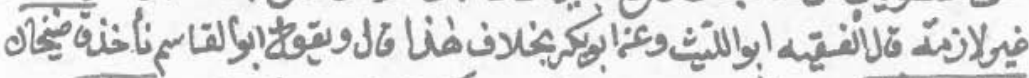

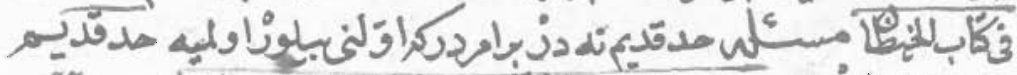

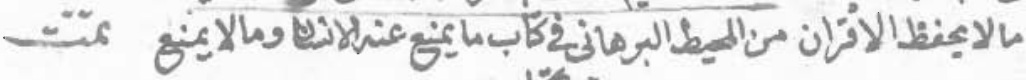
ب: 


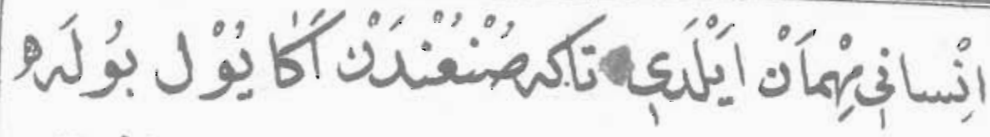

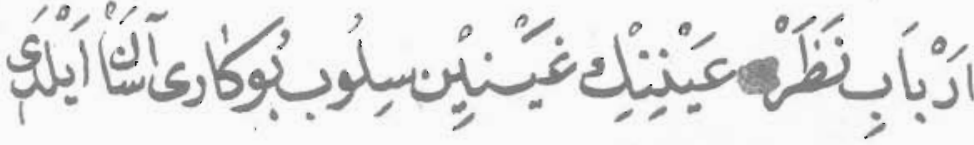

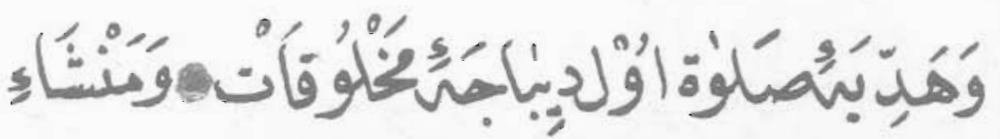

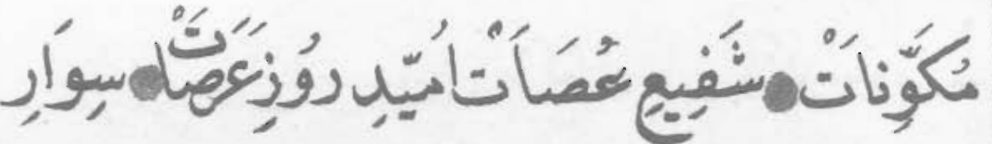

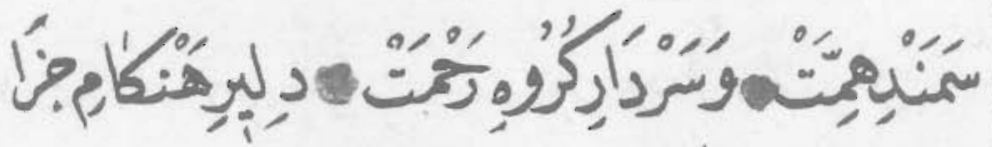

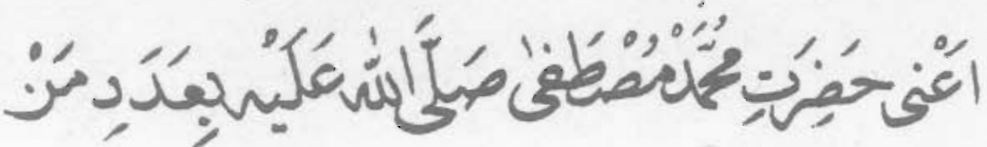

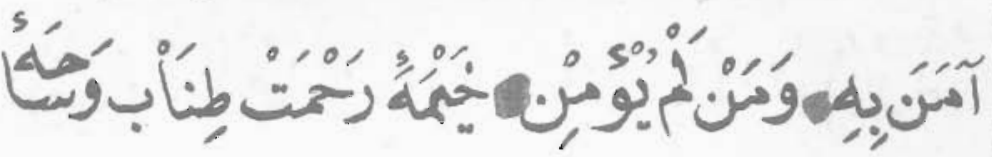

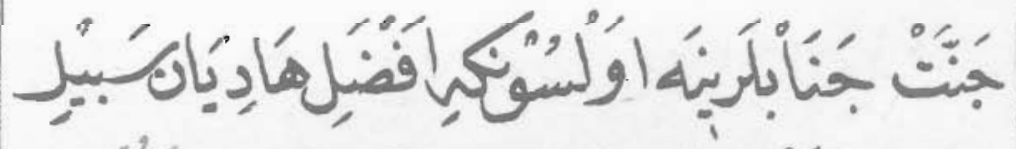

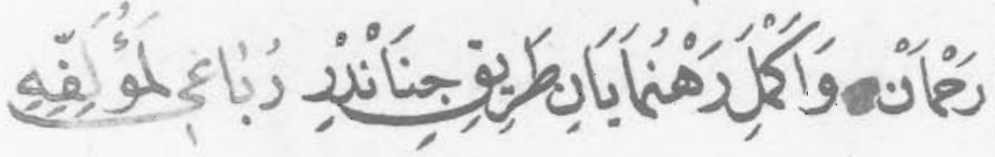

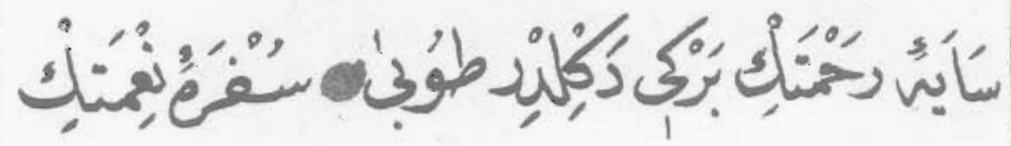

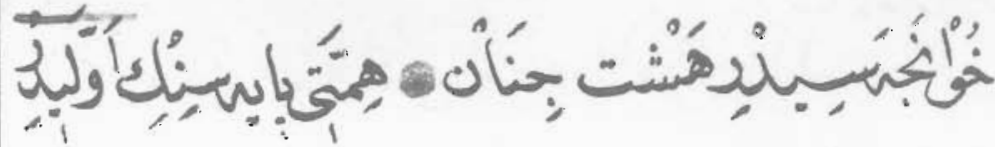

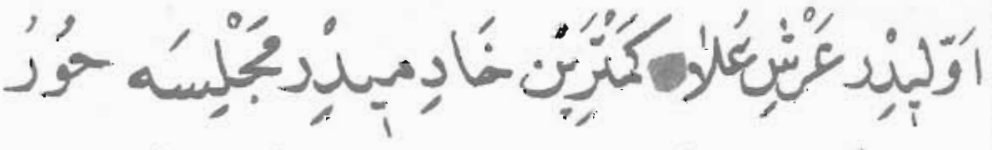

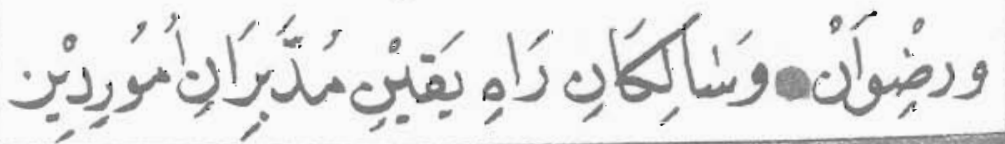

Figure 6. (No. 26, f. 2a) 


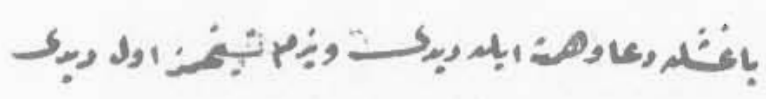

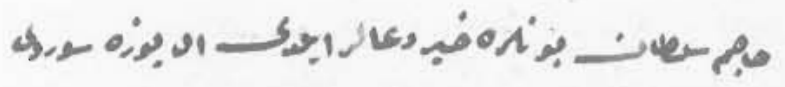

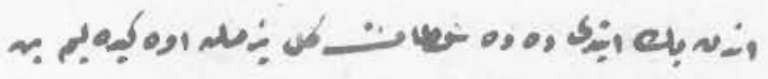

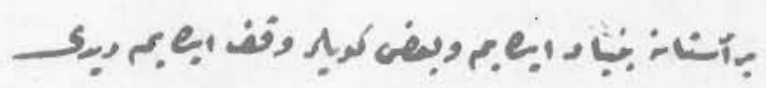

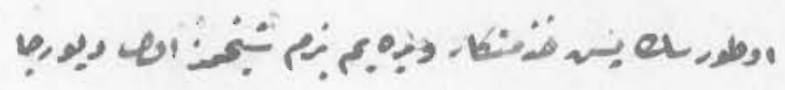

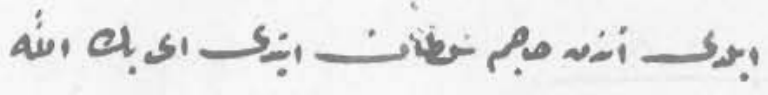

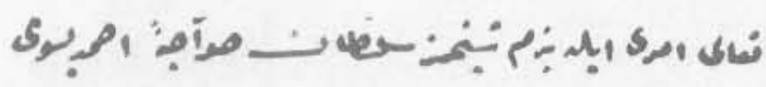

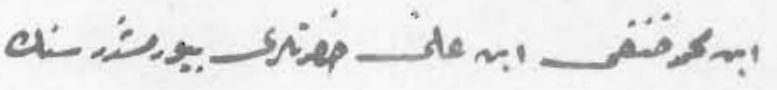

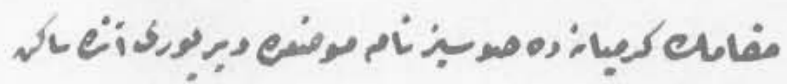

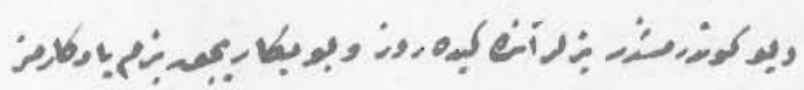

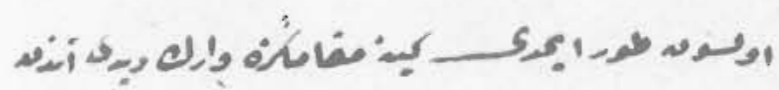

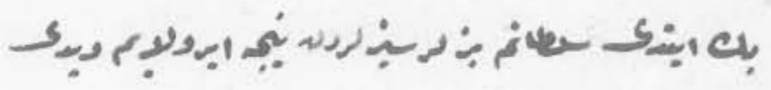

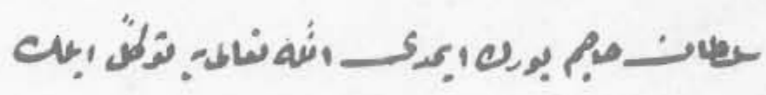

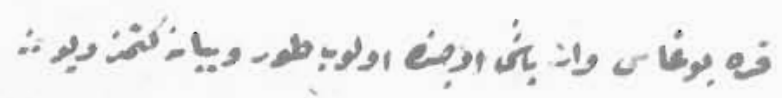

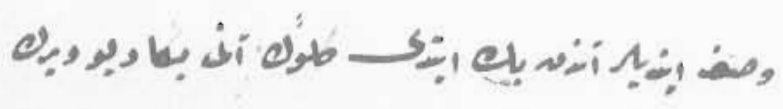

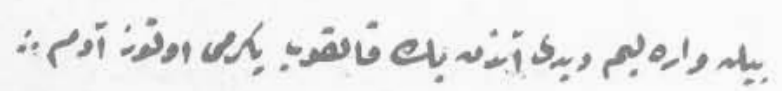

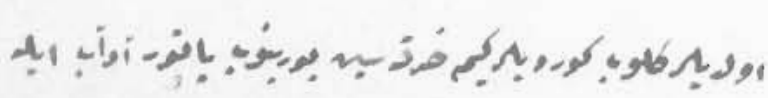

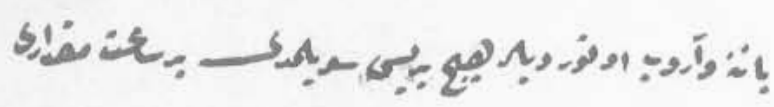

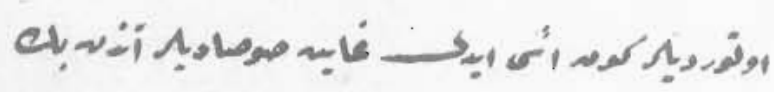

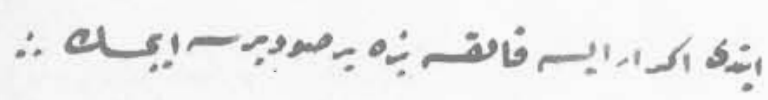

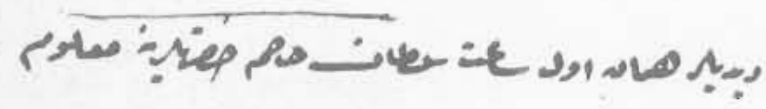

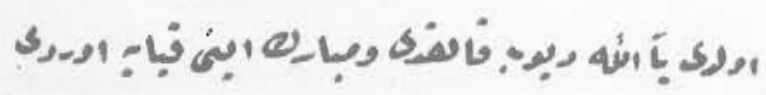

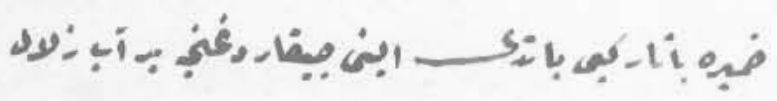
!

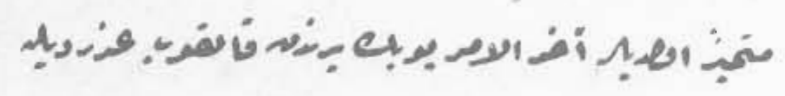

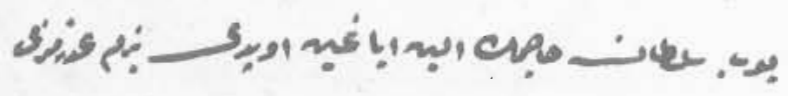
V.ức

Figure 7. (No, 46, f, 20b-21a) 


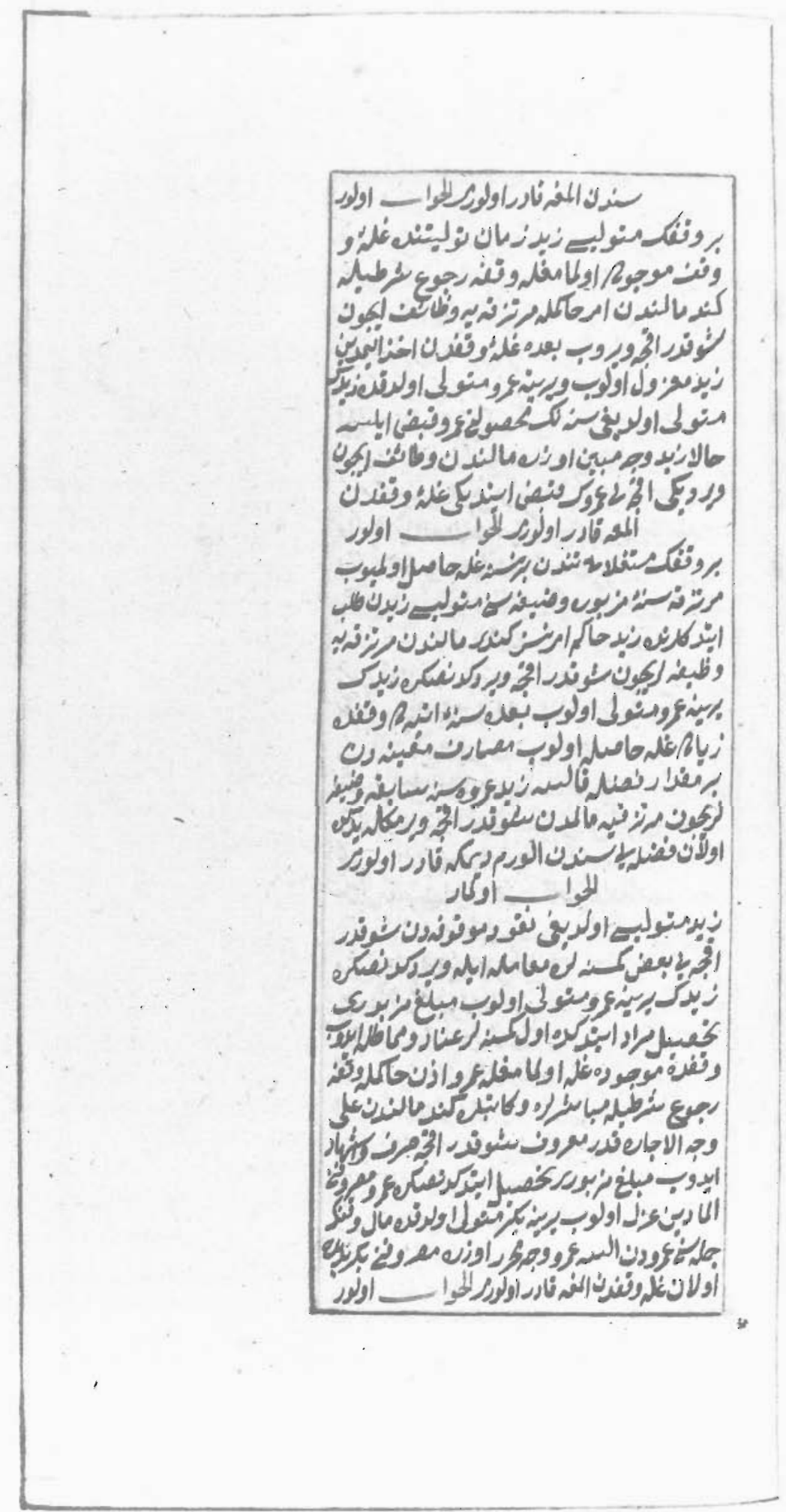

Figure 8. (No. 11, 1. 96a) 



\title{
Judge Robert MacKay's 1882 Catalogue of Books: A Preliminary Analysis
}

\author{
Peter F. McNally and Christina M. Boyle
}

\begin{abstract}
Robert Mackay (1816-1888) was a Judge of the Superior Court from 1868 to 1882, served on the McGill Board of Governors from 1879 to 1887 , and bequeathed his library to the University. The collection comprised two parts: "Legal" and "Miscellaneous." This article discusses the non-legal miscellaneous section, composed of 456 titles in 1,136 volumes, and analyses the collection under subject (10 categories), periodicals (13), country of publication (9), language (8) and period of publication (4). The subject classification is analysed and discussed in further detail.
\end{abstract}

Robert Mackay (1816-1888) a été juge à la Cour supérieure de 1868 à 1882, et a fait partie du Conseil des gouverneurs de McGill de 1879 à 188\%. Il a légué sa bibliothèque à l'Université. La collection se divise en de'ux parties: "juridique" et "divers." Cet article s'intéresse à la partie non juridique de la collection qui se compose de 456 titres en 1,136 volumes et l'analyse en fonction des sujets (10 catégories), des périodiques (19), du lieu de publication (9 pays), de la langue (8) et de la date de la publication (4). La classification par sujet est analysée en détail.

$\mathrm{H}_{\mathrm{is}}$ istorians of McGill University not only outline the administrative course of the University, they also trace its intellectual development: the ideas that shaped the University and the shape that the University gave to ideas. One of the ways of evaluating this intellectual ebb and flow is the library and its collections. These collections constitute a barometer of both the University's impact upon society and society's impact upon the University.

As a recent study indicated, the McGill Library catalogue of 1876, listing 5,201 titles and 11,021 volumes, provides a unique and convincing insight into the collection at that time, and thereby the intellectual state of the University. ${ }^{1}$ By 1882 , the collection had grown to 22,000 volumes, due largely to the gifts of individuals such as Peter Redpath, J.H.R. Molson, and T. Sterry Hunt. Unfortunate as it is that no other book catalogues of the entire collection were issued after 1876 , it is fortunate that catalogues were published thereafter of specific sections of the McGill collection. One such catalogue represents the gifts of Judge Robert Mackay, ${ }^{2}$ most of whose books can still be found on the shelves of the McGill University Libraries.

Robert Mackay was born in Montreal on October 27, 1816 and died there on February 23, 1888. After being admitted to the Bar on December 30, 1838, he developed a highly successful law practise in partnership with W.H. Austin, and received acknowledgement of his professional accomplishments by becoming Batonnier of the Montreal Bar. In 1867, he became Queen's Counsel and in 1868 Judge of the Superior Court. Due to ill helath, he retired from the judiciary on November 1,1882 . He was twice married, first to Ann Kearney of New York, who died in April 1843, and second on June 27, 1848 to Christina - daughter of the Honorable Thomas Mackay of Ot- 


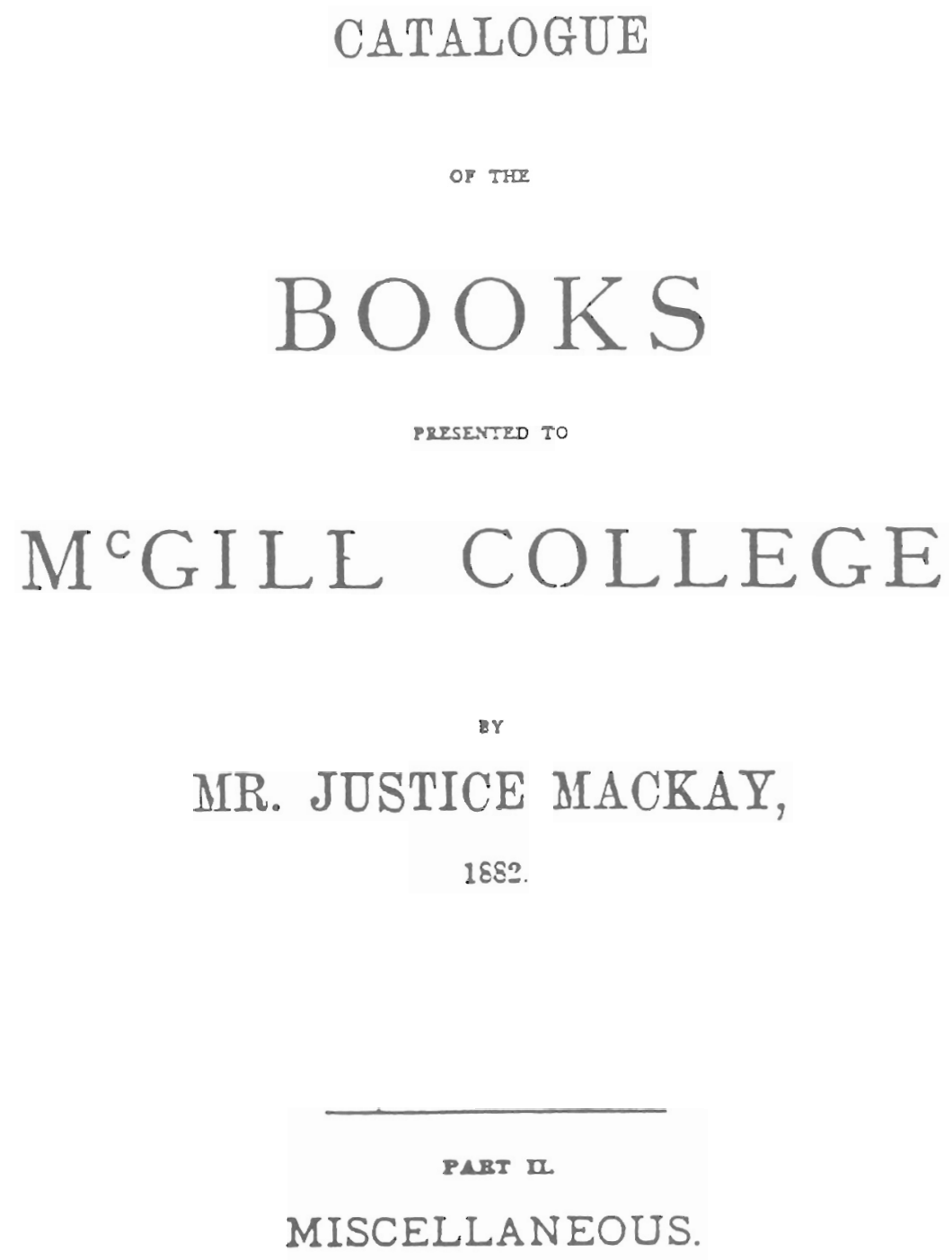

Yoci-ind:

PRLITED BJ JOEY LOVELL \& SOY, ST. NICEOLAS STREET. 1882. 
tawa, the builder of Rideau Hall - by whom he had a daughter. In addition to his legal/judicial career he had a great interest in art, becoming President of the Montreal Art Association in 1882. He was also a philanthropist, giving some of his art collection to the Fraser Library and donating money to the Diocesan Theological College. Most importantly for our story, he served on the McGill Board of Governors from 1879 until his resignation in December 1887, shortly before his death, and gave the University his library. ${ }^{3}$

Described in a catalogue published in $1882 / 1883$, Mackay's collection can be evaluated for both its quantity and quality, and for its interaction with the intellectual development of the University. Composed of approximately 2,000 titles, his collection would have constituted approximately $10 \%$ of the University Library book stock of the early $1880 \mathrm{~s}^{4}$ The collection is divided into two parts: Part I "Legal" and Part II "Miscellaneous," or non-legal publications. Interestingly enough, the imprint date of the title page for Part II is 1882, whereas that for Part I is 1883. It is unclear whether the two parts were issued separately or as one title. Since the analysis of Part I is still in progress, this paper will deal only with Part II, the non-legal "Miscellaneous" publications.

Part II is composed of 456 titles in 1,136 volumes. The total number of volumes may actually be larger, but bibliographical ambiguities make it difficult to identify certain titles: the entries are exceedingly brief, typically one line in length, with abbreviated author and title and rarely a date of publication, but usually an indication of number of volumes. Handwritten lists in the McGill Archives suggest that the books were received before being catalogued. ${ }^{5}$ Although there is no indication of who catalogued them, one can speculate that it was M. William Taylor, the Assistant Librarian. As the catalogue's titlepage makes clear, the arrangement was by subject, there being ten categories as follows:

Several points require clarification. Section E, "Parliamentary and Political," includes 90 volumes of British Parliamentary debates and histories, now located in the McLennan Library's Government Dockment Department. Section F, "The Works Of," handles the collected works of such authors as Voltaire (71 vol.), Burke (2 vol.) and Rabelais (1 vol.). Section H, "Classical Library," is a series of ciassical

\begin{tabular}{lcccc}
\multicolumn{5}{c}{ Table 1: } \\
\hline \hline $\begin{array}{l}\text { NUBJECT } \\
\text { TITLES }\end{array}$ & $\begin{array}{c}\text { NO. OF } \\
\text { VOLS. }\end{array}$ \\
\hline A. DICTIONARIES & 18 & 3.9 & 50 & 4.4 \\
B. HISTORY & 45 & 9.9 & 165 & 14.5 \\
C. BIOGRAPHY & 29 & 6.4 & 68 & 6.0 \\
D. POETRY & 20 & 4.4 & 63 & 5.5 \\
E. PARLIAMENTARY & 14 & 3.3 & 145 & 12.8 \\
$\quad$ \& POLITICAL & & & & \\
F. THE WORKS OF & 11 & 2.4 & 95 & 8.4 \\
G. RELIGIOUS & 41 & 9.0 & 54 & 4.8 \\
$\quad$ \& CONTROVERSIAL & & & & \\
H. CLASSICAL LIBRARY & 19 & 4.2 & $50 ?$ & 4.6 \\
I. HARPER'S FAMILY & 126 & 27.6 & 187 & 16.5 \\
$\quad$ LIBRARY & & & & \\
J. OTHER BOOKS & 132 & 28.9 & $257+$ & 22.6 \\
TOTAL & $456+$ & 100 & $1136+$ & 100.1 \\
\hline \hline
\end{tabular}

Table 2:

The Anti-Jacobin Review, 1798-1810, 36 vol.

The Illustrated London News, 1858-1871, 14 vol.

The Eclectic Magazine (Boston), 6 vol.

The Leisure Hour, 1854-1860, 1862-, 16 vol.

Good Words, 1860-, 12 vol.

The Penny Magazine, 1832-1845, 13 vol.

The Saturday Magazine (London), 1832-1844, 13 vol.

Bell's Weekly Messenger, 1814-1815, 2 vol.

Colonial Magazine, 3 vol.

Revue canadienne, 2 vol.

The Argosy, 2 vol.

The Art Union, 2 vol.

The Art Journal, 3 vol.

authors in English translation. Section I, "Harper's Family Library," is a miscellaneous series composed largely of non-fiction. Section J, "Other Books," is a richly textured group of books and periodicals, covering virtually every subject discipline. The collection contains thirteen periodical titles in approximately 124 volumes:

Whereas British publications predominated in the 1876 McGill Library catalogue, American publications predominated in Mackay's:

Of the American publications 155 , or $85.6 \%$ of their total, were published in New York City. Of the British, 139 or $86.8 \%$ were published in London, and only 13 or $8.1 \%$ were published in Scotland. Of the Canadian publications, 12 or $70.6 \%$ were published in Montreal. Analysis of the "Legal" Part of the catalogue will undoubtedly show a much higher pro- 
Table 3:

\begin{tabular}{lcc}
\hline \hline COUNTRY & $\begin{array}{c}\text { NUMBER OF } \\
\text { TITLES }\end{array}$ & $\%$ \\
\hline United States & 181 & 39.7 \\
United Kingdom & 160 & 35.1 \\
Canada & 17 & 3.7 \\
France & 13 & 2.9 \\
Belgium & 3 & 0.7 \\
Holland & 3 & 0.7 \\
Switzerland & 2 & 0.4 \\
Italy & 2 & 0.4 \\
Unknown & 75 & 16.4 \\
TOTAL & 456 & 100 \\
\hline \hline
\end{tabular}

Table 4:

\begin{tabular}{lcc}
\hline \hline LANGUAGE & NO. OF & $\%$ \\
& TITLES & \\
\hline ENGLISH & 409 & 89.7 \\
FRENCH & 30 & 6.6 \\
LATIN & 7 & 1.5 \\
ITALIAN & 3 & 0.7 \\
FRENCH \& ENGLISH & 3 & 0.7 \\
GREEK \& ENGLISH & 1 & 0.2 \\
POLYGLOT: LATIN, ITALIAN & 1 & 0.2 \\
$\quad$ DUTCH \& FRENCH & & \\
UNKNOWN & 1 & 0.2 \\
TOTAL & 456 & 166 \\
\hline
\end{tabular}

portion of Canadian imprints, which otherwise were significantly fewer than in the 1876 catalogue.

English was overwhelmingly predominant as the language of publication. Although the Latin language fell only from second place in the 1876 catalogue to third in Mackay, its proportion of the total was dramatically less. As for the titles in French, the number given here may be lower than is really the case, due to the tendency to translate titles into English. Some of these translations may have been missed in the analysis.

Although the date of publication of 80 titles, or $17.5 \%$ of the total, was indeterminable, the focus of those with dates was overwhelmingly upon the nineteenth-century:

The 1840 s, with 188 titles or $50 \%$ of the indentifiable total, provided the largest number of publications, and this suggests that Mackay did the bulk of his purchasing in this period. Virtually all of 126 titles in the "Harper's Family Library" series were pub-
Table 5:

\begin{tabular}{lcc}
\hline DATE & NO. OF TITLES & $\%$ \\
\hline $1551-1599$ & 3 & 0.8 \\
$1600-1699$ & 5 & 1.3 \\
$1700-1799$ & 23 & 6.1 \\
$1800-1880$ s & 345 & 91.8 \\
TOTAL & 376 & 100 \\
\hline \hline
\end{tabular}

Table 6:

\begin{tabular}{lcc}
\hline \hline SUBJECT & $\%$ & $\begin{array}{c}\text { No. OF } \\
\text { TITLES }\end{array}$ \\
\hline OTHER BOOKS & 28.9 & 132 \\
HARPER'S FAMILY & 27.6 & 126 \\
$\quad$ LIBRARY & & \\
HISTORY & 9.9 & 45 \\
RELIGIOUS & 9.0 & 41 \\
$\quad$ \& CONTROVERSIAL & & \\
BIOGRAPHY & 6.4 & 29 \\
POETRY & 4.4 & 20 \\
CLASSICAL LIBRARY & 4.2 & 19 \\
DICTIONARIES & 3.9 & 18 \\
PARLIAMENTARY & 3.3 & 15 \\
$\quad$ \& POLITICAL & & \\
THE WORKS OF & 2.4 & 11 \\
\hline \hline
\end{tabular}

lished in that decade. By comparison, all 19 titles in the "Classical Library" were published in the 1830s.

Subject analysis was undertaken first by reorganizing Table One in descending order by percentage of titles. As Table Six shows, "Harper's Family Library" and "Other Books" accounted for 56.5\% of the titles. Further subject analysis was clearly required to deal with this subject indeterminancy.

The Mackay entries were then checked in the McGill Library catalogues, where a high proportion were found with either Library of Congress or Cutter Classification numbers. The Cutter system was used at McGill until 1967 and is still in use for some older materials, whereas others have been reclassified into L.C. As much as possible, the classification numbers are presented as given in the catalogues, the exceptions being L.C.'s AC and Cutter's Y9, which are so general that it was deemed acceptable to reassign their titles to more appropriate categories. As two classification systems were being analyzed, they were blended as follows: 
Table 7:

\begin{tabular}{|c|c|c|}
\hline SUBJECT CLASSIFICATION & $\begin{array}{l}\text { NO. OF } \\
\text { TITLES }\end{array}$ & $\%$ \\
\hline $\begin{array}{l}\text { 1. DICTIONARIES, \& } \\
\text { ENCYCLOPEDIAS }\end{array}$ & 19 & 42 \\
\hline $\begin{array}{l}\text { 2. GENRAL WORKS } \\
\text { INCLUDING PERIODICALS }\end{array}$ & 12 & ¿.6 \\
\hline $\begin{array}{l}\text { 3. PHILOSOPHY, PSYCHOLOGY, } \\
\text { \& OCCULT }\end{array}$ & 19 & 4.2 \\
\hline 4. RELIGION & 56 & 12.3 \\
\hline 5. HISTORY, ALLIED & 6 & 1.3 \\
\hline 6. BIOGRAPHY & 41 & 9.0 \\
\hline 7. HISTORY & 114 & 25.0 \\
\hline $\begin{array}{l}\text { 8. GEOGRAPHY, TRAVEL } \\
\text { ANTHROPOLOGY, } \\
\text { \& RECREATION }\end{array}$ & 13 & 3.3 \\
\hline 9. SOCIAL SCIENCES & 9 & 2.0 \\
\hline 10. POLITICAL SCIENCE & 16 & 3.5 \\
\hline 11. LAW & 4 & 0.9 \\
\hline 12. EDUCATION & 3 & 0.7 \\
\hline 13. FINE ARTS \& ARCHITECTURE & 15 & 3.3 \\
\hline $\begin{array}{l}\text { 14. LANGUAGE } \\
\text { \& LITERATURE (GENERAL) }\end{array}$ & 4 & 0.9 \\
\hline 15. CLASSICAL L \& L & 22 & 4.8 \\
\hline 16. ENGLISH L \& L & 60 & 13.2 \\
\hline 17. ROMANCE L \& L & 7 & 1.5 \\
\hline $\begin{array}{l}\text { 18. SCIENCE, MEDICINE, \& } \\
\text { AGRICULTURE }\end{array}$ & 33 & 7.2 \\
\hline 19. UNKNOWN & 1 & 0.2 \\
\hline TOTAL & 456 & 100.1 \\
\hline
\end{tabular}

The results provide an invaluable insight to the collection. In Table Six, "History" and "Biography" account for $16.3 \%$ of the total, whereas in Table Seven sections 6 and 7 account for $34 \%$, and when taken with "Geography," section 8, for $37.3 \%$. In Table Six, "Dictionaries," "Poetry," "The Works Of," and "Classical Library" account for $14.9 \%$, but in Table Seven, sections 1, 13-17 dealing with language and literature account for $24.6 \%$. "Religious \& Controversial" rises from $9.0 \%$ in Table Six to $12.3 \%$ in section 4 of Table Seven. "Political" remains quite stable at $3.3 \%$ in Table Six and $3.5 \%$ in Table Seven. The appearance in Table Seven of section 18, "Science, Medicine, \& Agriculture," was an unexpected surprise. Overall, the subject analysis of Table Seven enhances the appreciation of the Mackay collection and shows that history, biography, language and literature were its focal point.

In evaluating this collection, it is easier to provide questions than answers. The first question is whether Mackay's books were acquired primarily for his own reading or, in the tradition of Peter Redpath, ${ }^{6}$ primarily for use in the McGill Library. Series such as the "Harper's Family Library" suggest personal reading, but the British Parliamentary histories and debates suggest an institutional Cestination. At least to some extent, Mackay may have been deliberately complementing the British history collection of Redpath, a fellow Board member. The next question is whether Mackay's books added to the quality of the McGill collection. To this, the answer is unequivocally yes, particularly given the small size of the University collection in 1882. Even if, by late twentieth-century standards of many of his books are now dated, at the time they would have been timely. At the very least, they are still of continuing historiographical importance, in charting the evolution of particular disciplines and topics. It should also be noted that the twenty-nine volumes of Canadian pamphlets, 1770-1854, listed in B, "History," helped form the nucleus of McGill's famous collection of rare Canadiana. That said, the emphasis upon history in the Redpath and Mackay collections seems extraordinary, given that McGill began teaching it only in the $1890 \mathrm{~s}$. Were these two men so visionary as to have realized that history would soon be taught and such collections would be needed? Or were they simply possessed of such a strong belief in history that, whether it was taught or not, they thought that the young college needed books on the subject? A final point is the phrase "Religious \& 
Controversial" in Table Six, which suggests a critical attitude towards religion that is reinforced by Mackay's funeral having been private and therefore possibly non-religious.

Finally, this evaluation must conclude with an admission that the "Miscellaneous" Part is the smaller portion of a collection, whose larger portion is the "Legal" Part, the analysis of which is required for the full significance of the Mackay books to become clear. In the meantime, one can only applaud the generosity of spirit that prompted Judge Robert Mackay to give such a fine collection to McGill's Library.

\section{Notes}

1. Peter F. McNally and Kevin Gunn, "The McGill University Library Catalogue of 1876: a Preliminary Statistical Analysis." Fontanus, from the Collections of McGill University, v. 9 (1996) pp. 120-124.

2. Catalogue of Books, by Subjects, of the Books Presented to McGill College. by Mr. Justice Mackay, 1882. Montreal, Lovell, 1882-1882. 2 parts [Part I, Legal, 1883, 26 p; Part II, Miscellaneous, 1882,16 p.].

3. Montreal Gazette, February 24, 1888, p. 4, February 25, p. 3, February 27, p. 2, February 28, p. 3, March 1, p. 3. Montreal Herald, February 24, 1888, p. 5, February 25, p. 8, February 27, p. 8, Henry J. Morgan, Canadian Legal Directory: a Guide to the Bench and Bar of the Dominion of Canada. Ioronto, Carswell, 1878. p. 234. Quebec Law Reports. v. III, no. II (November, 1882), List of Subscribers, P.-G. Roy, Les Juges de la Province de Québec. Québec, Sa Majesté, 1933. pp. 330-331. Brian Young, The Politics of Codification: the Lower Canadian Civil Code of 1866. Montreal, McGillQueen's, 1994. pp. 110, 214. There is some variation among the sources concerning the courts in which Mackay server as a judge, and his role in the development of the Quebec civil code.

4. McGill University Archives. Record Group 40, Jontainer 2, File "Principal Donors to the Library, 1882-1885-Lists".

5. -File "Mackay Library".

6. See P.F. McNally's forthcoming article on Peter and Grace Redpath. 


\title{
La Contribution de Maude Abbott au. Développement de la Muséologie Médicale (1898-1940)
}

\author{
par Hervé Gagnon et Christine D. Nadeau
}

\begin{abstract}
Après avoir terminé ses étuden de médecine en 1894, Maude Abboť jowe un rôle essentiel dans I'épanouissement de la muséologie scientifique, ề notamment médicale. En 1898, elle est nommée conservatrice adjointe, puis conservalrice, en 1900, du Musée de pathologie de McGüll. En 1905, elle publie le catalogue de la collection Osler. Pour elle, lo Musée de la médecine représentait un support pour l'enseignement de la médecine et elle prêtait des spécimens aux professeurs chargés de dispenser des cours cliniques. Elle a conçu un programme hebdomadaire de démonstrations en pathoiogie, quí a fait partie du programme d'études en pathologie de 1904 à 1922. Entre 1307 et 1938, Maude Abbotr a élé réáactrice an chef du bulletin de l'International Association of Medical Museums.
\end{abstract}

After graduating in Medicine in 1894, Maude Abbott ployed a prominent role in the development of scientific, especially medical, museology. In 1898 Abboit was appointed Assistani Curator, and in 1900 Curator, of the McGill Museum of Pathology. In 1905 she produced a catalogue of the Osler Collection. She saw the Medical Museum as an aid to the teaching of medicine and she loaned specimens to teachers of clinical courses. She developed a weekly program of pathology demonstrations which was part of the pathology curriculum from 1904 to 1922. From 1907-1938 Abbott was Editor of the Bulletin of the International Association of Medical Museums.

O plissement dans le domaine médical cue l'histoire a retenu le nom de Maude slizabeth Abbott. Toute la vie de cette femme aux talents multiples sera pourtani marquée par son caractère de pionnier, d'abord par son admission en médecine, puis par son apport a la connaissance des malformations cardiaques et, enfin, par son contribution au domaine - alors naissant - de la muséologie.

Bachelière de la Faculté des Arts de l'Université McGill en 1890, Abbott s'était vue refuser, l'année précédente, l'aúmission à la Faculté de Médecine de la même institution. ' L'élite médicale voit alors d'un mauvais oeil l'intrusion des femmes dans un domaine auquel leur sensibilité naturelle les prépare mal... C'est du moins l'opinion qu'émettent des éminences comme George Edgeworth Fenwick, professeur de chirurgie clinique et de médecine légale à l'Universić McGill, Sir William Dawson, paléontologue et géologue de renommée mondiale et principal de l'Université, et William Hale Hingston, chirugienchef de l'Hôtel-Dieu de Montréal et ancien maire de Montréal. ${ }^{2}$ Déterminée, Maude Abbott obtient, en 1834, son diplone de médecine du Bishop's College de Lennoxville, qui admet les femmes à sa Faculté de médecine depuis 1890 et demeure la seule institution d'enseignement supérieur au Québec à le faire jusqu'à sa fermeture en $1905 .{ }^{3}$ Elle devient ainsi l'une des premières femmes điplômées de médecine 
du Québec. ${ }^{4}$ Elle parfait ensuite sa formation à Zurich, à Vienne et à Édimbourg avant d'ouvrir son cabinet privé sur la rue Mansfield. ${ }^{5}$

C'est à l'Hôpital Royal Victoria et à l'Université McGill (dont elie reçoit d'ailleurs un doctorat honoris causa en 1936) que Maude Abbott développe l'expertise médicale qui fera d'elle une spécialiste des malformations congénitales du coeur ${ }^{6}$ qui publiera, au cours de sa carrière, pas moins de 116 articles médicaux. Parallèment, elle s'intéresse de près à l'histoire de la médecine et publie même un ouvrage sur le sujet.?

Les accomplissements médicaux de cette femme de science émérite ne l'empêchent cependant pas de jouer un rôle de premier plan dans le développement de la muséologie scientifique et particulièrement médicale, dont l'abondante littérature biographique qui la concerne ${ }^{8}$ traite par ailleurs relativement peu.

\section{Maude Abbott et le Musée Médical de l'Université McGill}

A. la fin du XIXe siècle, que l'on considère avec raison comme l'âge d'or des musées, l'institution muséale présente un visage renouvelé. Façonné par la montée des nationalismes, par l'industrialisation et l'enrichissement qu'elle génère au sein des classes dominantes, de plus en plus préoccupé par un passé que les changements technologiques repoussent rapidement vers l'oubli, le musée est en voie de dénocratisation. Les grandes lignes des principaux. types muséologiques (art, histoire, histoire naturelle, sciences, technologie) sont désormais fixées. Les grandes institutions qui marquent aujourd'hui le monde muséal ont ainorcé leur histoire. ${ }^{9}$

La fin du XIXe siècle est marquée par un vaste mouvement de renouvellement du discours muséologique, d'origine essentiellement américaine, et par un redéfinition dư rôle même des musées. On accorde dorénavant une importance plus grande au grand public. Les notions muséographiques d'éclairage, de circulation, de disposition spatiale des exhibits prennent une importance nouvelle. Globalement, le musée cesse alors d'être un reposoir d'objets ou de spécimens pour devenir un véritable lieu d'interprétation, un support pédagogique où le visițeur accroit sa compréhension d'un sujet au contact des présentations en place.

On essiste, à compter du début du XXe siècle, à l'apparition d'une nouvelle profession: la muséologie, qui fait l'objet de cours à l'Université d'towa a compter de 1907 puis dans dix-sept autres institutions américaines entre 1920 et $1929 .^{10}$

Au Québec comme ailleurs, les institutions d'enseignement supérieur sont impliquées dans ce processus de professionnalisation par l'intermédiaire des trombreux musées qu'elles possèdent. Entre 1900 et 1920 , on trouve en effet, à l'échelle de la province, plus une cinģuantaine de musées pédagogiques gérés par les deux principales universités, McGill et Laval, ainsi que par le réseau des collèges catholiques. La fin du XIXe siècle et les premières décennies du XXe donnent enfin lieu à l'apparition des premiers manuels professionnels, ce qui traduit bien la préoccupation montante de l'époque pour les musées. ${ }^{11}$

L'Université McGill s'inscrit de plein pied dans ce mouvement. Dès 1860, William Osler, pathologiste au Montreal General Hospital, commence à y regrouper des spécimens anatomiques et pathologiques qui serviront de noyau au futur musée de médecine. ${ }^{12}$ À compter de 1882 , on y trouve le Musée Redpath, véritable joyau d'architecture muséale où conservées principalement les collections pédagogiques de sciences naturelles et d'ethnologie de l'Université. ${ }^{13}$ En 1893, grâce à une fondation privée, on crée le Musée d'hygiène de McGill, symbole de la montée de l'hygiène publique à Montréal dont les expositions se préoccupent des problèmes "relating to disinfection, lighting and heating; water, buildings, soil, air, drainage, and refuse disposal, foodstuffs and clothing, vital statistics, and bacteriology and pathology in relation to public health." ${ }^{14}$ Suite à l'agrandissement de l'édifice de la Faculté de Médecine en 1899 grâce un don de Donald Smith, Lord Strathcona, l'Université compte également sur des musées de pathologie (désigné sous le vocable du Musée Médical après 1907), de gynécologie-obstétrique, d'anatomie et de pharmacie. ${ }^{15}$ S'ajoutera à ceux-ci, en 1921, le Musée McCord, reposant sur la collection d'histoire et d'ethnologie accumulées depuis les années 1880 par David Ross McCord. ${ }^{16}$

C'est encore à l'Université McGill que l'on dispensera, de 1930 à 1934, sous le titre de "Techniques de musées," le premier cours de muséologie au Canada sous la tutelle de Lionel E. Judah, alors secrétaire du General Museums Committee de McGill. Ce cours d'une durée de cinq jours, bilingue 
à compter de 1933, comprend un programme de conférences et des visites de musées. Il s'intéresse à tous les types de collections, à leur gestion et à leur mise en valeur au profit du public. ${ }^{17}$

C'est dans ce contexte de professionnalisation que s'inserit l'apport de Maude Abbott au domaine de la, muséologie, qui prenára des formes diversifiés allani de la classification des collections à la mise à profit du potentiel pédagogique de l'institution en passant par le développeinent d'un réseau international de musées médicaux.

\section{Le développement du Musée Médical}

En 1898, alors qu'elle pratique à l'Hôpital Royal Victoria depuis un an à peine, Maude Abbott est nommée conservatrice-adjointe du Musée de pathologie de l'Université McGill, puis y obtient le poste de conservatrice en 1900 . Elle professionnalisera rapidement cette fonction essentiellement honorifique.

Lorsque Abbott le prend en charge, le Nusée compte environ 180 spécimens collectionnés par Osler. Tout au long de sa tenure, elle collectionnera les spécimens à un rythme qui dépasse amplement la capacité d'accueil et d'entreposage de l'institution. Une photographie datant de 1905 témoigne déjà de l'entassement qui affecte le Musée, les spécirnens étiquetés s'accumulant du plancher au plafond, dans des armoires vitrées aussi bien que sur des tables. ${ }^{18}$

En 1921, la collection exposée et en réserve au Musée atteint 7030 spécimens, auxquels s'ajoutent, fruits des goûts d'Abbott pour le sujet, des objets reliés à l'histoire de la médecine et à l'histoire de la Faculté de Médecine de l'Université. Il s'agira par exemple d'un sceau de l'Université d'Édimbourg, et line médaille d'argent remise par The Natural History Society of Montreal au Dr. Archibald Hall, professeur à la Faculté de médecine et co-fondateur du British American Journal of Medical and Physical Science. En 1932, suite à la parution du rapport de Cyril Fox sur l'état des musées de l'Université McGill, dans lequel on recommande une distinction plus claire entre le contenu du Musée Médical, où se trouvent des séries médicales et des collections liées à l'histoire de la médecine, et celui du Musée de pathologie, qui contient des collections pédagogiques, ${ }^{19}$ le Musée Historique Médical voit le jour. Maude Abbott, qui en est responsable, établit le statut, les objectifs, les besoins, le bud- get et les liens avec les bibliothèques médicales de l'Université. ${ }^{20}$

L'ampleur du collectionnement effectué par Abbott s'explique en partie par le fait qu'elle développe rapidement un réseau international de collectionnement dont l'efficacité lui sera d'un grand secours après l'incendie qui ravage le Míusée de pathologie en 1907. Cette année-là, en effet, le feu détruit la quasi-totalité des collections: 700 spécimens osseux; les spécirnens consacrés aux dornaines "salivary, biliary, pancreatic, renal, vesical, prostatic calculi and enteroliths"; la collection d'obstétrique-gynécologie "with the exception of a few monstrosities"; les spécimens d'anomalies cardiaques et de dyphtérie; les tumeurs du larynx; les spécimens de maladies occulaires et particulièrement "a beautiful collection of inounted specimens of the eyeball"; et plusieurs autres secteurs. ${ }^{21}$ Tout au plus a-t-on réussi à sauver environ 140 des 180 spécimens originaux de William Osler. En réaction au sinistre, Abbott fonde en 1907 l'International Association of Medical Museums et lance un appel aux institutions membres en vue d'obtenir des spécimens de remplacement. Elle en reçoit plus de 3000 qui lui permettront de continuer à travailler à l'un de ses principaux champs d'intérêt: la classification.

\section{La classification des collections}

En décembre 1898, Maude Abboti, alors conservatrice-adjointe du Musée de pathologie de McGill, est déléguée à Washington pour visiter le Army Medical Museum et rencontre William Osler, qui l'encourage à appliquer dans les plus bref́s délais au Musée de pathologie les standards professionnels naissants de la muséologie médicale - tout en ne ménageant pas les éloges indirects envers une collection dont l'essentiel lui est alors attribuable:

I wonder, now, if you realise what an opportunity you have? That McGill museum is a great place. As soon as you go home look up the British Medical Journal for 1893, and read the article by Mr Jonathan Hutchison on "A clinical Museum." That is what he calls his museum in London, and it is the greatest place of life I. know for teaching students in. Pictures of life and death together. Wonderful. You read î and see what you can do. ${ }^{22}$

Vraisemblablement inspirée par l'appui d'Osler et par les lectures qu'il lui suggère, Abbott ap- 
pliquera au musée ses premières normes de classification. Elle amorce sans tarder des recherches dans les registres des autopsies du Royal Victoria et y découvre deux volumes de notes post-mortem rédigés par Osler où se trouvent le nom ou le numéro de l'hôpital où plusieurs des spécimens originaux de la collection avaient été enregistrés. ${ }^{23}$ En 1899, le professeur W. Johnston obtient l'adoption, par le Comité du Musée de pathologie, du système décimal de classification et de catalogage Dewey. Abbott procède immédiatement à l'application de ce système aux collections du Musée et en publie les résultats en $1903 .{ }^{24}$ Pour chaque spécimen, classifiés selon les dix systèmes du corps humain, la condition anatomique se voit attribuer les chiffres précédant le point décimal alors que la condition pathologique est représentée par ceux qui le suivent. Celles-ci se subdivisent à leur tour et ainsi de suite, de façon à permettre le degré de précision requis par la classification de chaque spécimen. ${ }^{25}$

A bbott voit dans ce système l'avantage d'une classification efficace qui permet une utilisation pratique des spécimens par les professeurs et les étudiants tout en tenant compte de la croissance des collections et des raffinements ultérieurs de la classification. C'est également grâce à l'existence d'un tel catalogue descriptif que le conservateur constatera les faiblesses de la collection du musée et sera en mesure de les combler. ${ }^{26}$

Elle entreprend également, en 1905, l'élaboration d'un catalogue de la collection Osler, qui possède une valeur aussi bien historique que médicale. Elle amorce donc la classification descriptive des séries de spécimens, chacune devant être précédée, dans le catalogue final, d'une introduction rédigée par un. spécialiste en la matière. ${ }^{27}$ Elle prévoit d'ailleurs se charger elle-même de la section consacrée au système circulatoire. L'incendie de 1907 détruit cependant la plus grande partie du catalogue déjà rédigé. ${ }^{28} \mathrm{En}$ 1910, Osler s'engage à obtenir les sommes nécessaires à la publication du catalogue et propose qu'on lance le prenier volume lors de l'inauguration du nouvel édifice du Musée de Médecine, en juin. Le travail avance toutefois trop lentement au goût d'Abbott:

Since (...) April 1910, the section on spleen and ductless glands under Dr. Gruner has been practically completed, but progress in other sections has been, for various reasons, slight. ${ }^{29}$

Ce n'est qu'en 1915, dix ans après que la publication en ait été proposée, que parait, grâce à un don du. Copper Fund, la première section du catalogue de la collection Osler dont le Canadiañ Medical Association. Journal souligne la qualité et la logique. ${ }^{30} \mathrm{Au}-$ cun autre volume ne sera toutefois publié ou même complété, si bien qu'en 1940, le doyen de la Faculté de médecine de l'Université, J.C. Simpson, propose de ne plus financer l'entreprise. ${ }^{31}$

\section{La collection, outil pédagogique}

En accord avec le discours muséologique de l'époque, Maude Abbott exploite abondamment le potentiel pédagogique que l'on reconnait désormais aux musées et̂ à leurs collections.

Considérant avant tout le Musée médical comme un auxiliaire de l'enseignement de la médecine $\mathrm{Ab}$ bott voit dans le prêt de spécimens aux professeurs de cours cliniques une des fonctions premières de l'institution. A cet effet elle développe dès 1905 sur un système de prêts reposant sur une liste d'emprunteurs et exigeant le retour des spécimens dans les 48 heures. ${ }^{32}$

Le musée est cependant plus qu'un dispensaire de spécimens et Abbott y élabore une structure hebdomadaire de démonstrations pathologiques qui, de 1904 à 1922, font partie intégrante du curicuIum du cours de pathologie. ${ }^{33} \mathrm{Au}$ cours de ces démonstrations les étudiants abordent, selon l'ordre anatomique, l'une des dix sections du Musée correspondant aux dix systèmes du corps humain. Chaque système étant à son toưr subdivisé selon ses différents organes, on effectue une rotation jusqu à ce que tous les sujets d'intérêts aient été couverts. Les étudiants sont ensuite appelés à examiner en groupe des spécimens disposés sur une table, à discuter et à formuler des opinions en se référant au besoin aux manuels de référence disponibles sur place. ${ }^{3 h}$ C'est cependant l'enthousiasme de Maude Abboti pour cette démarche pédagogique que les étudiants semblent le plus apprécier. "Untiring, generous, enthusiastic, Dr. Abbott made events live and specimens speak. 135

Abbott tre également parti de l'insertion de la collection anatomo-pathologique dans la formation médicale des étudiants pour initier ceux-ci au travail de classification muséale et aux méthodes descriptives. Chaque étudiant se voit ainsi attribuer quelques spécimens au sujet desquels il doit remplir un formulaire portant le sujet, la date, le numéro du spécimen, le nom, la description de l'apparence 
anatomique et pathologique, un commentaire et une comparaison avec les autres spécimens alloués. ${ }^{36}$

Encouragée par le rôle joué par son Musée dans l'enseignement médical, Abbott recommande en 1919 qu'il soit oficiellement reconnu. comme un département autonome de l'Université et que sa conservatrice soit désignée comme "Official and Executive Head of the Museum." 37 La démarche n'aura toutefois pas de succès. Son travail 52 'en est cependant pas moins reconnu par ses collègues. $\grave{A}$. plusieurs reprises, Charles F. Martin, professeur à la Faculté de Médecine attaché à l'Hopital Royal Victoria, lui fera part de son admiration et de celle de William Osler pour la structure pédagogique qu'elle a su installer au Musée pathologique:

I am delighted. (...) Our museum here is building far as to exceed anything I ever saw for beauty and practical usefuiness. ${ }^{38}$

I enclose Dr. Osler's letters. If you only could have heard how nice he spoke of your remarkably excellent work and its great nission for students and for museum teaching (...).

Abbot diffuse encore les collections cu Musée en utilisant les spécimens dans des publications scientifiques, généralement rédigées en collaboration avec des collegues médecins. ${ }^{39}$

\section{L'exposition, moyen de communica- tion scientifique}

Il va également de soi que les expositions constituent à ses yeux un outil de communication privilégié. A cette fin, les organes et systèmes examinés lors des démonstrations sont ensuite mis en exposition à. l'intention des étudiants. De même, il est toujours possible, sur demande d'un professeur, qu'une série anatomique particulière soit exposée et, au besoin, démontrée par le conservateur. Enfin, en mars de chaque année, on procède à. l'exposition annuelle de tous les spécimens préparés depuis un an ${ }^{40}$

A.u cours de sa carrière de conservatrice Maude Abbot démontre, en plus de ses préoccupations pédagogiques et pour la classification, une graride activité dans le domaine des expositions. Au cours de la seule année 1913, elle monte ainsi des expositions au profit de l'American Interurban Orthopedic Society et de l'International Congress of Surgeons, toutes les deux en visite à. Montréal, et monte deux expositions itinérantes, la première à l'intention de la Section de techniogue muséale de l'International Congress of Medicine ¿̀ Londres en août et la seconde au congrès de la Section américaine de l'International Association of hedical Museums à. Toronto. ${ }^{41}$ En 1917, elle présente des spécimens devant la Montreal Medico-Chirurgical Society. ${ }^{42}$ L'année suivante, elle se retrouve en charge de l'exposition de la Conadian Medical Association à Hamilion ét y présente la première exposition du Canadian Army Medical Museum préparée et montée sous sa supervision à l'Université McGill. ${ }^{43}$

En 1931, elle présente un exposition intitulée "Development of the heart and the clinical classification of congenital disease" au Graduate Fortnight in Cardiology, à New York puis, l'année suivante, dans le cadre du Centenary Meeting of the British Medical Association. ${ }^{44}$ En 1933, l'Université McGill participe à l'exposition Internationale de Chicago. Intitulée "A. Century of Progress," cette exposition est consacrée au progrès qu'a connu l'humanité depuis la fin du XIXe siècle. ${ }^{45}$ Dans cet ordre d'idées, McGill y présente dans le Pavillon des sciences six panneaux conçus par Abbott et portant sur l'histoire de l'Université mais aussi sur l'êvolution du Montreal General Hospitai, sur la vie et l'oeuvre de Sir William Osler, sur les maladies cardiaques congénitales et sur la neuro-chirurgie. ${ }^{46}$ La même unnée, le Musée Médical présente une expositior. portant le titre "Cancer as a Virus Disease." 47

\section{Maude Abbott et le développement des musées médicaux}

L'apport muséologique de Maude Abbett est cependant loin de se limiter au seul Musée Médical de l'Université McGill. Touc au long de sa carrière, en parallèle avec son travail à McGill, elle jouera un rôle considérable dans le développement international de la muséologie médicale.

En 1914, le British Medical History Committee entreprend de faire constituer par les unités médicales de tous les pays servant sous le drapeau britannique, une collection de spécimens pathologiques recueillis destinés à un éventưel Musée de la Guerre. Suite à la présentation de cette collection au public londonien en 1915, dans le cadre de l'Imperial War Exhibit, les spécimens sont retournés à leurs pays respectifis. À compter de 1918, les premiers spécimens destinés au future Canadian Army Medical Museum arrivent au Canada à coup d'une cinquantaine par mois et 
sont dirigés vers le Musée Médical de Mcrill, désigné dépôt officiel. ${ }^{48}$

En 1919 Miaude Pbbott est nommée conservatrice du nouveau musée et supervise, avec l'aide du préparateur Lionel Judah et du général J. T. Fotheringham, la préparation, le montage et le catalogage des spécinens. ${ }^{19}$ En 1920 , l'exposition ainsi montée est présentée dans le cadre de la rencontre de l'American Congress of Surgeons a Montréal. On amorce également la préparatiun d'un catalogue de la voliection an oasant sur celu de la collection Osler; comme derrier, il ne sera jamais complétéso

C'est coutefors par son irnplication sur la scène internationale que Maude Abbott laisse sa marque la plus tangible dans le développement de la muséologie. Suite à l'incendie çui ravage son musée en 1907, ello met en effet sur pieds l'International Association of IViedical Museums, dont elle est élue trésorière. Fill iemeurera de plus éditrice de son Bulletin ce 2907 a 1938 , en plus de travailler avec acharnernent is sor sucess, comme s'en souvient un collaborateur: "The large membership of the Association itself is due in no small measure to Dr. Abboti's power of infecting others with her own keenness and enthusiasm." 51

Par l'intermédiaire de cette association, elle cherche avant tout à promouvoir les normes modernes de la muséologie qri'elle appliqune déjà nit Musée Médical de McGill:

To promote and encourage the building up of collections in localities where, in the presence of a rich pathological material, a museum does not yet exist; to foster the growth and extend the scope of existing museums, by facilitating the interchange of specimens along special lines; to aid such institutions as are labouring under unfavourable conditions, and difficulties; to increase the usefulness of the organised museum as a teaching medium both by improved aethods of classifying and cataloguing and by proper preservation of specimens to develop such to their highest points. ${ }^{52}$

Abbott parvient à obtenir l'appui financier do Ionald Smith, Lord Strathcona, qui Iui fait parvenir en 1913 la somme, coquette pour l'époque, de $\$ 5,000$ pour assurer le roulement de l'Association. L'arrivée de la première Guerre Mondiale ralentit cependant considérablement les activités en Europe et, jusqu'à la. fin du conflit, l'Association sera essentiellement l'affaire des musées nord-américains. ${ }^{53}$ La guerre et ses élans de patriotisme poussent par ailleurs Abbott à considérer certaines modifications dans la structure de l'organisme pour la réorganiser strictement autour des pays alliés:

in following up thas idea we do not intend to abandon the International name, but to drop out of the membership all but members in allied and neutral countries, and we feel very strongly that now that the United States have entered the war, our machinery should be utilised to co-ordinate the work among the allied membership. ${ }^{j} 4$

Au fil des ans, l'International Association of Medical Museums, qui a ses origines et son siège social au Musée Médical de l'Université McGill, se développe en un réseau international d'échange de spécimens et d'information qui atteint, au cours des années 1930, plus de 300 insticutions membres. ${ }^{55}$

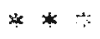

Le propre d'une note de recherche est avant tout d'indiquer le potentiel documentaire des sources relatives à un sujet donné en tirer de conclusion hâtives. A cet égard, des recherches plus approfondies permettront sans doute de confirmer l'importance du rôle joué par Maude Ábbott dans le domaine de la muséologie scientifique tout en la relativisant davanuge. Nols n'avons offert ici que des pistes de recherche que d'autres emprunteront.

Vne note de recherche, lorsqu'elle concerne un individu, a aussi cette particularité de n'aborder que les principales réalisations d'un personnage et d'en tracer un portrait parfois plus flatteur que ne le feront les recherches subséquentes. Or, il faut bien l'arimettre, malgré l'avant-gardisme de ses activités muséologiques, Maude Abbott semble entreprendre beaucoup plus de projets ciu'elle n'en termine, ce qui s'explique aisément par le fait qu'elle est avant tout médecin et que ses activités scientifiques ont certainement préséance sur ses fonctions au Musée Médical. Entreprenante jusqu'à l'éparpillement elle a le défaut, commun à plusieurs scientifiques, de courir trop de lièvres à la fois, comme le mentionne un ancier assistant au Musée: "She had sbout a dozen irons in the fire at the same time, and all seemed in confixion."

Il ne faut pas nor: plus croire que son parours 
muséologique est sans enbûches et indépendant des circonstances matérielles. Lorsque, en 1925, l'Université McGill met sur pieds un General Museums Committee chargé de gérer l'ensemble des musées qui se trouvent sous sa juridiction, c'est Lionel F. Judah et non Maude Abbott qui devient conservateur de l'ensemble de ces musées et, en théorie du moins, Abbott se trouve désormais sous la tutelle d'un supérieur. ${ }^{56}$

Le fait demeure cependant que, dans l'histoire des musées au Québec, Maude Abbott demeure un pionnier dont la contribution au développement de la muséologie se compare aisément à celle de Lionel Judah.

\section{NOTES}

1. McGill University Archives (MUA), Fonds Maude Abbott, MG 1070, 684/38, Autobiographical Sketch, p. 129.

2. Margaret Gillet Ritchie, We Walked Very Warily: A History of Women at McGill, Montréal, 1981, pp. 285-286.

3. Denis Goulet et André Paradis, Trois siècles d'histoire médicale au Québec. Chronologie des institutions et des pratiques (1639-1939), Montréal, VLB éditeur, 1992, p. 423.

4. Luc Chartrand, Raymond Duchesne et Yves Gingras, Histoire des sciences au Québec, Montréal, Boréal, 1987, p. 350.

5. MUA, Fonds Maude Abbott, MG 1070, C2, $80 / 4 / 43$, item 39 , p. 1.

6. Chartrand eí al., itistoire des sciences..., p. 350 .

7. Maude Abbott, History of Medicine in the Province of Quebec, Montréal, McGill University Press, 1931.

8. H.E. MacDermot, Maude Abbott, A Memoir, Toronto, The MacMillan Company of Canada Ltd., 1941, 264 pp; Anthony R.C. Dobell, "Maude Abbott: Portrait of a Pioneer," Reprint from Congenital Heart Disease, 1982, pp. 237-263; Douglas Waugh, "Maudie: The Life and Times of McGill's Maude Abbott," Annals of the Royal College of Physicians and Surgeons of Canada, 24, 7 (décembre 1991), pp. 486-488; Kathleen Smith, "Maude Abbott: Pathologist and Historian," Canadian Medical Association Journal, 127 (15 octobre 1982), pp. 774-776; Richard Sutherland, "The Magnificient Maude," Current Therapy (février 1990), pp. 14-16.

9. Voir entre autres: Daniel J. Sherman Worthy Monuments, Art Museums and the Politics of Culture in Nineteenth-Century France (Londres, Harvard University Press, 1989), 337 pp.; Joel J. Orosz, Curators and Culture: The Museum Movement in America (1740-1870), (Tuscaloosa, University of Alabama Press, 1990), 304 pp.; Hudson, Kenneth, Museums of Influence, Londres, Cambridge University Press, 1987, 220 pp.; Kennedy, John Michael, Philanthropy and Science in New York City: The American Museum of Natural History, 1868-1968. Thèse de Ph.D., Yale University, 1968; Schaer, Roland, L'invention des musées. Paris, Gallimard, 1992. 144 pp:; Tomkins, Calvin. Merchonts os Masterpieces. The Story of the Metropolitan Museum of Art. New York, Henry Holt and Company, 1989. 415 pp.

10. Paul Carle et Michèle Metzener, "Lionel E. Judah et la formation en muséologie au Canada," Muse, VIII, 4 (hiver 1991), pp. 67-68.

11. Valentine Ball, Report on the Museums of America and Canada, Extracted from the Report of the Science and Art Department, for the Year 1884, 1884; Léon Provancher, "Tableau synoptique des musées," Naturaliste canadien, 16, 7, 1887, pp. 130136; Henry Marc Ami, Reporit on the State of the Principal Museums in Canada and Newfoundland. 1897; David Murray, Museums: their History and their Use (with a Bibliography and List of Museums in the United Kingdom), Glasgow, James MacLehose \& Sons, 1904. 3 volumes; Sir Henry Miers et S.F. Markham, A. Report on the Museums of Canada, Edinburgh, Constable, 1932.

12. Archie F. Key, Beyond Four Walls. The Origins and Development of Canadian Museums, Toronto, McClelland and Stewart, 1973, p. 112. Cyril Simard et al., Patrimoine muséologique au Québec. Repères chronologiques, Québec, Commission des bien culturels, 1992, p. 25.

13. Susan D. Bronson, The Design of the Peter Redpath Museum at McGill University: the Genesis, Expression and Evolution of an Idea about Natural History, Mémoire de M.Sc.A (architecture), Université de Montréal, 1992, et "The Design of the Peter Redpath Museum at McGill University: The Genesis, Expression and Evolution of an Idea About Natural History," Bulletin de la Société pour l'étude de l'architecture au Canada, 17, 3 (septembre 1992), 
pp. 60-76; Barbara Lawson, Collected. Curios. Missionary Tales from the South Seas, Montréal, McGill University Libraries, 1994, 313 pp.; Paul. Carle et Alain Mongeau, "Le cas de l'Université McGill et du Musée Redpath pendant; la première moitié đu XXe siècle," Musées, 11, 1/2 (1988), pp. 6-10.

14. Cité dans Key, Beyond Four Walls..., p. 112.

15. Martha Benjamin, The McGill Medical Library, 1829-1929, Mémoire de maitrise (library science), Université McGill, 1960, p. 25. Cyril Fox, A Survey of McGill University Museums, Montréal Quality Press Ltd., 1932.

16. Pamela Miller et al., La famille McCord. Une vision passionnée. Montréal, Musée McCord d'histoire canadienne, 1992, pp. 84-100.

17. Carle et Metzener, "Lionel E. Judah. et la formation en muséologie au Canada," pp. 67-69; Simard et al., Patrimoine..., pp. 51, 57.

18. Maude Abbott, "Dr. Osler's Later Relations with the Museum (1898-1913). Personal Reminiscence," Bulletin No. IX of the International Association of Medical Museums and Journal of Technical Methods. Sir William Osler Memorial Number, (1926), p. 197.

19. Fox, A Surveg..., pp. 15-21.

20. MUA, Fonds Medicine, RG41, C10, 38/80/6, 12 décembre 1932.

21. Maude Abbott, "Appeal. for Specimens for the Medical Museum of the McGill University," The International Association of Medical Museums, 1 (1907), pp. 9-10; Key, Beyond Four Walls..., p. 112.

22. Cité dans MacDermot, Maude Abbott..., p. 74.

23. Maude Abbott, "The pathological collections of the late Sir William Osler at McGill University," Bulletin of the International Association of Medical Museums and Journal of Technical Methods, 9, p. 96.

24. Maude Abbott, "On the classification of museum specimens," American Medicine (1903), p. $543-544$.

25. Pour la condition anatomique: "Circulatory System, Respiratory System, Digestive System, Lymphatic System and Ductless Glands, Urogenital System., Female Generative System, Nervous System, Tegumentary and Muscular System, Osseous and Articular System, Regional." Pour la condition pathologique: "Abnormalities, Circu- latory Disturbances, Inflammations, Infections and Parasites, Granulomas and General Diseases, Progressive Changes, Retrogressive Changes, Wounds and Injuries, Specific Artefacts, General Supplementary." Abbott, "On the Classification of Museum Specimens," p. 543 .

26. Maude Abbott, "The museum in medical teaching," Joumal of the American, Museum Association (1905), p. 937-938.

27. MUA, Fonds Museums, RG41, C10, 5I5/2, réf. $38 / 80 / 1$.

28. MUA, Fonds Medicine, RG38, C2, Dossier 51, Minute Book of the Museum Committee, 17 mars 1909, p. 7.

29. MUA, Fonds Museums, RG41, C10, 515/2, réf. $38 / 80 / 1,17$ mars 1913.

30. The Canadian Medical Association Journal, 5 (1915), p. 811.

31. MUA, Fonds Medicine, RG38, 38/30/73/22, 30 décembre 1940.

32. Abbott, "The museum in medical teaching", p. 937.

33. MUA, Fonds Maude Abbott, MG $50 \%$, 684/38, p. 144.

34. Abbott, "The museum in medical teaching," p. 937.

35. Helen MacMurphy, "Dr. Abbott's place in medicine," McGill Medical Journal, 10, 1. (1940), pp. $43-47$.

36. Abbott, "The museum in medical teaching", p. 938 .

37. MUA, Fonds Maude Abbott, MG 1070, C4, item 52v, 4. octobre 1919.

38. Osler Library Collection and Archives (ALCA), Fonds Maude Abbott, MS 438/56, boite 2, Lettres de C.F. Martin à Maude Abbott, 29 décembre 1905; 20 juillet 1910.

39. Maude Abbott et Joseph Kaufmann, "Doulble monster of: Janus type; Cephalothoracopagus Monosymmetros Cyclops Synotos," Maude Abbott et G.W. Pheland, "Foetus Holoacardius Acormus in heterologous (triplet) pregnancy," Maude Abbott et Frederic T. Lewis, "Reversed torsion of the ventricular bend of the embryonic heart in the explanation of certain forms of cardiac anomaly," The International Association of Medical M'useums, 6 (août 1916); Maude: Abbott et E. Shanly, "Cardiac defects 
in the light of the comparative anatomy of the vertebrate heart," The International Association of Medical Museums and Journal of Technical Methods, 8 (décembre 1922).

40. Abbott, "The museum in medical teaching;" p. 9.37.

41. MUA, Fonds Medicine, RG 38, C2, dossier 51 , 30 avril 1914, p. 81.

42. The Canadian Medical Assaciation Journal, 8 (1918), pp. 278-285 offre une description complète de l'exposition.

43. Abbott, "Autobiographical sketch...," p. 150 et MUA, Fonds Maude Abbott, MG 1070, C4, item $52 \mathrm{v}$, Second Report to Museum Committee on war specimens, 22 mars 1918.

44. Maude Abbott, "The McGill University Exhibit," The British Medical Journal (décembre 1932), pp. 1197-1199. Maude Abbott, "The McGill University exhibit on the development anư comparative anatomy of the heart and the clinical classification of congenital cardiac disease," Journal of Technical Methods and Bulletin of the International Association of Medical Museums, 13 (mars 1934).

45. Wolfgang Friebe, Buildings of the World Exhibitions, Leipzig, Éditions Leipzig, 1985, pp. 144-150.

46. MUA, Fonds Museums, RG41, C10, 38/51/5A, McGill's part in the Chicago exhibition, 13 octobre 1932.

47. MUA, Fonds Museums, RG41, C10, 684/56, réf. $30 / 80 / 8$.

48. Maude Abbott, "The preparation of the Canadian Army Medical Museum, and its descriptive catalogue in collaboration with experts," International Association and Journal of Technical Methods, 8 (décembre 1922), pp. 34-39.

49. MUA, Fonds Maude Abbott, MG 1070, C4, Item $52 \mathrm{v}, 21$ février 1918.

50. MUA, Fonds Medicine, RG38, 38/30/73/22, 30 décembre 1940; Fonds Maude Abbott, RG38, 38/30/73/22, r février 1932.

51. William Boyd, "Dr. Maude Abbott," Journal of Technical Methods and Bulletin of the International Association of Medical Museums, 18 (octobre 1938), pp. 1-2.

52. Bulletin of the International Association of Medical Museums, 1 (15 mai 1907), p. 1.

53. MacDermot, Maude Abbott..., p. 112, "5.
54. MUA, Fonds Maude Abbott, MG1070, C4, item $52 v$, lettre de Maude Abbott à Arthur Keith, Royal College of Surgeons, 6 août 1918.

55. Key, Beyond Four Walls.., p. 112.

56. Carle et Matzener, "Lionel E. Judah...," p 38; Simard, et al., Patrimoine..., p. 51. 



\section{Cultural Diversity and Human Rights*}

\section{by Stephen J. Toope}

F.R. Scott was a poet, an advocate and a scholar who cared passionately about human rights in Canaula and around the world. Building from Scott's poem "On Kanbawza Road," the author extrapolates a vision of what Western actors must do to achieve a true dialogue on human rights that respects cultural diversity.

The shift in focus from the setting of recognized standards to the implementation of those norms has increased tensions in the area of international human rights. The attempts to define, categorize and group human rights have been less successful at achieving consensus than they have been at unearthing the Western philosophy of the core of the exercise. Revealing these. Western sources has only exacerbated the existing clash-of-cultures debate. The author questions what is meant by culture within that debate. He argues that culture operates on the levels of form, structure and myth, but emphasizes the need to recognize the mythic level of human rights in the Western tradition. Two difficulties then arise. Is a society's culture defined solely at the structurat level by the legally legitimate state, or do other entities matter as well? However it may be defined, is that culture then susceptible to change, or do its values ensure some form of purity? The author argues that the answers to both inquiries are not reached in as static a manner as clash-of-cultures proponents wouid seem to believ?.

Using his interpretation of "On Kanbawza Road" as a guide, the author indicates that human-rights discussions must move beyond arguments over which philosophy underpins whose terminology. Common values within contrary terms and tenets must be recognized. All voices within a cultural group deserve to be heard. The Western listeners must be humble, approaching the encounter with neither an accusatory nor condescending predisposition.

F.R. Scott était un poète, un avocat et un professeur qui avait à coeur la protection des droits de la personne, tant au Canada que dans le reste du monde. À partir du poème "On Kanbawza Road," de F.R. Scott, l'auteur propos: un discours sur les droits de la personne qui respecte la diversité culturelle.

Le passage d'une ère de création de normes à une ère de mise en place de ces normes a accru la tension dans le domaine des droits de la personne. Plutôt que de créer un consensus, les diverses tentatives visant à définir, à catégoriser et à grouper les droits de la personne ont a vour résultat de révéler l'eurocentrisme des valeurs véhiculées. La prise de conscience des racines occidentales des droits de la personne n'a fait qu'exacerber le débat entourant le choc des cultures.

L'auteur remet en question \a définition de "culture" telle qu'employée dans ce débat. Il affirme que la culture opère au niveau de la forme, de ia structure et du mythe, et it souligne l'importance du contenu mythique dans 'e discours sur les droits de !a personne à l'intérieur de la tradition occidentale. Deux problèmes se

\footnotetext{
"This text is a revised version of the annual F.R. Scott Lecture, delivered on 8 May 1996 to the Friends of McGill Libranes anci was originaliy published in the McGill Law Journal/Revue de droit de McGill, vol. 41, No. 1, February 1997, pp. 169-185. The editor of Fontanus wishes to thank the Editor of the McGill Law Journal for peroaission to re-publish this lecture. Copyright remains with the McGill Low Journal, 1997.
} 
posent alors. Tout d'abord, la culture droit-elle se définir uniquement au niveau structurel de l'Etat légitimement constitué, ou doit-on tonir compte d'autres entités à l'intérieur de l'État? Par ailleurs, la culture est-elle susceptible de changer et d'évoluer, ou doit elle plutôt être perçue comme la réalisation concrète de valeurs pures? La réponse à ces deux questions ne saurait êtrc aussi statique que le laissent. entendre les tennats du choc des cultures.

A partir de son interprétation du poème "On Kanbawza Road," l'auteur conclut qu'il est temps d'abandonner le débat sur les valeurs philosophiques véhiculées par la terminologie des droits de la personne. Il importe plutôt de rechercher les valeurs communes qui sont wéhiculées par des terminologies t, des doctrines contradictoires. Toutes les voix méritent d'être entendues. L'auditozre occidental se doit d'écouter avtc humilité, sons accusation et sans condescendance.

\section{Introduction}

A up the Deanship of McGill's Faculty of Law. F.R. Scott is apocryphally reported to have delivered an Eleventh Conmandment: "Thou shalt not commit deanery." I know exactly what he meant. F.R Scott was a poet, an advocate and a scholar. He would never have wanted to see himself defined as an administrator.

The invitation to deliver this lecture has proven to be a gift of great value to me, for it has helped me to escape - if only briefly - from the confines of academic administration. I have had occasion to re-read the collected verse of Frank Scott, and can only reaffirm J. King Gordon's evaluation "an emancipated spirit found expression in his poetry, in his fine sense of humour and in his enthusiasm." "I have also been forced to reflect upon my theme - cultural diversity and human rights - in the shadow of Scott's keen intellect. Finally, I have been called upon to visit and use a McGill library. Although I seem to spend much of my time soliciting donations for the library system, all too few occasions arise for me to explore its rich resources.

$X$ have felt the personal imprint of F.R. Scott's legacy over the last few weeks. The poet, the advocate and the scholar - I have been privileged to engage with all three facets of Scott as I prepared this lecture. I also sense another connection, made palpable by my own Trinitarian definition of Scott's career. Although it is secularized in his poetry, I detect in Scott an imprint of the Anglican rectory: recall the famous "Creed" which includes the declaration that "The spirit of man is my God/The future of man is my heaven." ${ }^{2}$ One of the many strains of Anglicanism emphasizes social justice and religious pluralism. Again in the words of $\mathrm{J}$. King Gordon: "Scott had grown up in a home where the Christian imperative was expressed through a faith in the aspirations of men and womes.." 3 I share that imprint. and it draws me emotionally to Scott: thuse aspirations - for respect, for dignity - are the subjecl of my discussion.

F.R. Scott cared passionately about human rights. Aside from his famous engagements as a barrister before the courts of Quebec and the Supreme Court of Canada, when he "went to bat for the Lady Chatte" 4 and took on Maurice Duplessis, ${ }^{5}$ Scott was also an unrepentant proselytizer. In 1959 he gave a series of four lectures on C.B.C. Radio entitled The Canadian Constitution and Human Rights. In these lectures he assessed the historical legacy of human rights in Canada, and proposed the crealion of a charter of rights entrenched in the written constitution. Even in his poetry, Scott often adopted the tone of the optimistic advocate, albeit in the lyrical voice. I quote from "Spain 1937,"6

In the spring of ideas they were, the rare spring

That breaks historic winters. Street and field

Stirring with hope and green with new endeavour,

The cracking husks copious with sprouting seed.

Here was destruction before flowering.

Here freedom was cut in its first tendrils.

The issue is not ended with defeat.

Scott was also committed to the celebration of cul- 
tural diversity. if quote in its brief entirety "Bonne Entente ${ }^{x .7}$

The advantages of living with two cultures Strike one at every turn,

Especially when one finds a notice in an office building:

"This elevator will not run on Ascension Day";

Or reads in the Montreal Star:

"Tomorrow being the Feast of the Immarulate Conception.

There will be no collection of garbage in the city":

Or sees on the restaurant menu the bilingual dish:

DEEP APPLE PIE

TARTES AUX POMMES PROFONDES

Mais ces réflections ne sont pas des révélations. Nous connarssons bien Scott le défenseur des droits de la personne et Scott l'observateur ironique des deux solitudes canadiennes (une idée qu ii n'a dailleurs jamars acceptéc). Co qui ma le plus frappó en relisant son oeuvre, cest un thème qui rejont mes propres préoccupations, à savvoir les droits de la personne ét la diversité culturelle dans une perspectivi. globale. Nous considérons solivent. Scott comme le symbole du patriotisme canadien. cependant son aîtachement à une certaine idée du Canada était fondé sur son dévouement profond pour l'amélioratıon de la cundition humaine.

Permit me to quote at length what has become my favourite Scott poem - "On Kanbawza Road": 8

In Southeast Asia

the Buddhist ivew Year

starts with a water festival

lasting for days

Everything is put aside

for this glorification

of rebirth

Even the guerrillas

who regularly cut the water-main

into Rangoon

promised no damage to the pipe-line

during these celebrations
Only astrologers can tell

the exact moment.

when the god descends

and the year is born

A gun booms out their message

And walking by the Kanbawza Hotel

on that bright morning

under a torrid sun

I approached a gate on the roadway

where stood a girl-child

not three feet high

holding a bowl of water

with a spray

of the sacred tha-hve tree

She too was celebrating

she was waiting to sprinkle

cach passerby

with the symbolic drops

But I I was a white man

standing so far above her

not rasy to anoint

She moved toward ne

then drew back.

afraid

She understood the ritual

taught in her family

but never dreamed a foreign giant.

mught need her blessing

Seeing her torn

between faith and fear

I sat down on my heels

Burmese fashion

levelling my cyes with her eyes

At once her fear vanished

she smiled a.t, me

her little trands

dipped the sprig in the bowl and touched me with the fertility

of love

In our torn century, despairing of faith and filled with fear, how can we find ways to touch each other "with the fertility of love"? I believe that true dia- 
logue across cultures on the fundamental questions of respect for persons and human dignity can provide us all with such moments of transcendence as experienced by F.R. Scott on Kanbawza Road.

Scott himself has provided three clues as to how such transcendence can occur. First, we musi place ourselves in direct contact with other cultural tradutions. Contact does not presuppose comprehension; but a. willingness to enter into situations where. diverse perspectives and attitudes are voiced is a precondition to any ultimate shared understanding Secondly, we musi be willing to ask for the blessings of others, especially those less powerful than ourselves. In his encounter with the lithe girl on Kanbawza Road. Scott recognized both his physical power as a "giant" and his social power as a "foreign giant". But he also knew that he needed the girl's blessing, which would be a surprise to her Thirdly, Scott tells us to sit down on our hecls and level our eyes with people from other cultural traditions. Only then is any real communication possible.

Ces intuitions sont d'une importance capitale à notre époque. Fn effet, malgré la grande tradition du discours sur les droits de la personne issu des cendres de la deuxième gucre mondiale, nous sommes menacés aujourd'hu par un contrecourant. Des clameurs insistantes s'élèvent contre les normes internationales des droits de la personne, à l'effet qu'il ne sagit que d'un nouveau cheval de Trore qu. permettrait à l'impérialisme occidental de refleurir Loin de promouvoir la solidarité, ces normes camoufleraient une idéologie sectaire.

\section{The Internationai Haman-Rights Sys- tem}

I would like to offer a personal, perhaps idiosyncratic, reading of the contemporary international human-rights debate. I sense that a significant underlying reason for the emergence of a clash-ofcultures rhetoric in international human-rights discussion is the movement from so-called "standard setting" (the period from 1948 to the mid-1980s when governments tried to reach agreement upon explicit standards to which they would be willing to be bound) towards an implementation of norms. The new focus upon implementation of "universal" norms, as pursued by international nongovernmental organizations and a number of Western governments since the mid-1980s, has heightened interregional tensions associated with human rights. This was inevitable: once one begins to stress implementation rather ihan articulation of norms, states no matter what their cultural or ideological roots will feel threatened. This is particularly true in the area of human rights, where the mechanisms for implementation remain largely political rather than legal In turn. when rights are invoked in political discourse and given real bite, not only will inplementation processes be challenged, but greater scruiny will be applied to the substantive conten of the rights being called into play.

I want to emphasizo the weak role of internatiunal legal mechanisms in the implementizion of humanrights standards. ${ }^{9}$ The Interuational Court oï Juscice ("I.C.J.") has been almost wholly inactive in the area of human rights, as have most other adjudicatuve bodies. with the notable exccptions of thc European Court of Human Rights and, to a lesser extent, the Inter-American Court of Iuman Rights. ${ }^{10}$ The new tribunal empowered to hear cases involving war crimes and crimes against humanity in Rwanda and the former Yugoslavia has been hamstrung by an inability to pursue accused perpetrators and by a lack of political will on the part of states which trumpeted its creation. The various committees which sit under a diverse group of international covenants, such as the International Covenant on Civil and Political Rights, ${ }^{11}$ the International Covenant on Economic, Social and Cultural Rights, ${ }^{12}$ and the Convention on the Elimination of All. Forms of Discrimination against Women, ${ }^{13}$ are limited in power and in their permitted scope of inquiry. With the exception of the Human Rights Committee when sitting under the terms of the Optional Protocol to the International Covenant on Civil and Politica! Rights, ${ }^{14}$ all of the committees are resiricted to receiving and commenting upon state reports relating io the national implemunuition of the relevant convenion. The reports of some states are cursory at best, willfully misleading ai worsi. Evon the Human Rights Committee, which has jurisdicion under the Optional Protocol to hear individual complaints, can only "forward ius views, at the end of any particular case, to the state involved. ${ }^{15}$ There is no mechanism for implementation of a commitice decision, aside from the court of public opinion.

Therefore, implementation of human-rights norms by states is largely dependent upon overtly political action in bilateral diplomacy. or in multilateral 
fora such as the Human Rights Commission of the United Nations. Recently, the establishment of the office of U.N. High Commissioner for Human Rights has provided another focus of attention for human rights within the U.N. system. However, the high cormuissioner's power is highly circumscribed, and the first incumbent has taken a cautious approach t.o his job. ${ }^{16}$

Le mise en application multilatérale de ces normes est instaurée de façon régionale par l'intermédiaire d'organismes tels que le Commonwealth, la Francophonic et l'Organisation pour l'unité africaine. La mise en application dans ces fora sera presque entièrement politique: les États seront soumis à un examer international et éventuellement condamnés. Dans certains cas extrêmes, des sanctions pourraient être imposées.

By far the most common form of implementation of human-rights standards by states remains traditional bilateral diplomacy. This can extend from oral condemnations through ambassadorial demarches to formal contacts with opposition and human-rights organizations. In extreme cases, linkages may be made with state policies relating to aid and trade. Such linkages, however, appear to have been lessening, rather than increasing. over the last few years. The current Canadian government has in most cases explicitly rejected the linkage of human rights with aid and trade initiatives. ${ }^{17}$

Diplomatic activity in support of human righis engages cultural diversity in both positıve and negative ways. To the extent that diplomacy opens up multilateral or bilateral negotiations. cultural factors can be raised, assessed and debated. However. diplomacy is inevitably charged with the burden of broader interstate relations which can result in the mixing of agendas. In addition, negotiations are very much infuenced by imbalances of power. Moreover, as quintessential interstate activities, negotiations will be affected by issues of regime legitimacy. Negotiators may reach accommodations which are not supported by the citizenry, or negotiations may fail when negotiators lack respect for the "opposing" regime.

This brief outline of the international humanrights system is intended merely to reiterate my central point that international human-rights law is weakly articulated in terms of implementation mechanisms. For that reason, political implemntation is iequired and this inevitably sets up significani tensions between states. These tensions are inherent in the post-World War II structure of international relations. The Charter of the United Nations makes a number of references to the promotion of human rights as a goal of the organization and its members. ${ }^{18}$ Yet simultaneously, article $2(7)$ of the Charter emphasizes the traditional principle of nonincervention in the incernal affairs of states. The promotion of human rights inevitably results in intervention, broadly conceived, thereby creating political tensions based upon traditional understandings of sovereignty. When implementation becones the focus of international human-rights debates, tensions rise and resistance appears on the part of many states. $^{19}$

\section{Definitional Issues}

\section{A. Human Rights}

The first question I want to pose is fundamental: what do we mean by "human rights"? In anthropological or sociological terms, human rights is really nothing more than a "symbol" of respect for persons. ${ }^{20}$ As such, it is a cultural artifact with both positive and negative aspects. The positive aspects are obvious: human rights is a collective statement that individuals and social groups matter and that they cannot simply be treated as means to overriding ends. More negatively, one might argue that invoking rights implies that we are less interested in the welfare of a person from a caring perspective. ${ }^{21}$ There may indeed be some lost social and moral value when an explicit declaration of respect is needed to replace innate patterns of social behaviour rooted in a culture that promotes respect for others.

But these observations are not particularly satisfying from a lawyer's perspective. That is why F.R. Scott was so committed to an explicit and constituitionally entrenched charter or bill of rights within Canada. Lawyers constantly strive - rightly and wrongly ... for more precise and more "legal" definitions of human rights. Rather than being mer's descriptors of social behaviour. norms have legal significance when their substantive conient is articulated and implemented through juridical processes that uphold the values of, inter aliu. justice, equality, fairness and transparency. In principle, a right insulates its holder from mere, utilitarian or instrumental claims or other claims based purcly upon so- 
cial good. Because the right is a form of insulation, it protects individuals and groups from majoritarianism.

None of this is to say, bowever that rights are absolute. They are defeasible under certain circumstances by ouher rights and sometimes even by necessity and scarcity arguments as long as demorratically validated legal processes (which arc open and transparent) are used to identify the reasonable limit.s upon the right. I underscore this point becalise it becones important later: in any sophisticatcd Western philosophical tradition. rights are subject to processes of balancing. althorgh there is no consensus upon the ideal balance to be achieved. This desire for balarire is manifest in the principal international insiruments, including the Universul Decluration of Human Right.s ${ }^{22}$ (drafted by another distinguished McGill colleague, Professor Tohn Humphrey). ${ }^{23}$

N'oublions pas que l'origine de beaucoup de termes retenus clans les conventions internationales sur les droits de la personne remonte aux ćcrits du dixhuitiòme siècle en Europe el en Amérique, notamment à la declaration des droits de l'homme et la déclaration d'indépendance des États-Unis. On peut également remonter jusqu'à Aristote et à la Magna Carta pour retracer les sources de cette tradition. Jo tiens à souligner les origines terminologiques des droits de la personne par souci de clarté: l'expression des normes internationales est issue d'une longue tradition philosophique et politique occidentale ${ }^{24}$

The contemporary teminology of human rights even within the Western tradition - is ideologicaily loaded. For example, the eminent philospher isaiati Berlin emphasized the difference between so-called negative and positive rights. ${ }^{25}$ Negative rights were said to be individual rights that inhibited state actron: the individual had a right to be "let alone" by the statc. On the other hand, positive righis werc those rights that required active state intervention. such as the large body of cconomic, social and cultural rights. This characterization led some commentators and political figures to argue that only negative rights were roal rights and that positive riglits were nothing more than entitlements. ${ }^{26}$

Another term often used to describe a certain category of rights is "fundamental rights." The diffculty is what one chooses to include within the category. For most Western governments, fundamental rights have traditionally included only civil and poliical rights, most notably the freedons of expres- sion, association, assembly and religion. The use of the term "fundarnental" can imply that there is a clear hicrarchy of rights with these being more important than the others. But as soon ats one atrempts to establish such a hierarchy, one discovers how artificial the attempt really is. For that reason, many contemporary scholars would argue that all human rights arc important and that they are inutually reinfurcing. ${ }^{37}$

I want to discuss as well the approach based uon "grnerations" of rights. a term coined by Karel Vasak. ${ }^{28}$ According to this terminology, the first generation of righis encompasses civil and political rughts, including the "fundamental rights." the panoply of legal rights, democratic-pirlicipation rights, and a whole scries of ant idiscrimination rights based on defined categories such as sex, race and religion. ${ }^{29}$ The second generation of rights includes all economic, social aild cultural rights, such as the right, to food, heallh, cducation, work and social security. ${ }^{30}$ The implementation of these rights requires domestic and mucrnational actuon, and a reasscssment of public-spending priorities. 'The third generation of rights would include the right to development, which is to be found in the Uninicrsal Declaration of Human Rights dating from $1948,{ }^{31}$ as well as the right to a healthy enviromnent, the right to pence and the right to humanitiarian assistance ${ }^{32}$ Here the focus is almost entirely upon international cooperation as a menns to implementation of the rights. If a siatc is nut in a position to fully implement the right to development, for example, then the people of that state should be entitled to assistance from other states in order to give effect to the right. It will be obvious that such a right is likcly to cause consternation in the halls of power of many Westem democracies. The right to developmont is very expensive to implement.

in short, the evolution of human-rights discourse over the: last. forty years has been marked by an cven increasing list of rights and various attenuts at categorization. The effort to define hierarchies of rights has been unsuccessful, but has itself fed ideological confrontation.

\section{B. Culture}

A second fundamental definitional question is what we mean by "cultural values," the values which are said to be in contlict. when we discuss human rights in an international setting. If the notion of rights is a difficult concept, culture is even more 
complex and multifaceted Roy Preiswerk has defined culture as "a cotality of values, institutions and forms of behaviour transmitted within a society ... [which] covers Weltanschaung [world view]. ideologies and cognitive behaviour." ${ }^{33}$ A more succinct definition is offered by Clifford Geertz, who characterized culture as "an historically transmitted partern of meanings embodied in symbols." 34

One helpful symbol of culture is the tree ${ }^{35} \mathrm{At}$ the top of the tree, we see its ultimate flourishing: branches and leaves. Tn the leaves and branches we see the form of the culture, including patterns of behaviour, custom, language, arts and history Just below we see the most impressive element of the tree. its trunk. In the trunk we see the structure of the culture, involving family arrangements, social organization and practices in economics, politics, health care, education and law. Underground, of course. are the nourishing roots, the system that allows the tree to flourish. In the roots, we see the mythic level of culture: world view, attitudes towards time and space, epistemology, values and cosmology. Of course, the depth of the roots, the sturdiness of the trunk and the shape and texture of the leaves - the evolution of a culture - will depend upon climate and other environmental conditions.

In some senses, the idea of human rights operates at all three levels of culture, it expresses itself in form, structure and myth. But what? wan to emphasize is that the Western view of human rights is rooted in myth, in the generative sense of that word. Western versions of human rights are largely anthropocentric and they focus upon autonomy of the individual, treating people as ends in themselves Of course, this mythology is then expressed in structural legal terms, but human rights is not essentially a legai concept. Rather, important expressions of the concept have precise legal meanings when filtered through a value-laden legal system that shapes and constrains definition, norm identification and processes of implementation.

If this approach to culture has any utility, it highlights two important difficulties. First, we must ask who participates in the construction of "culture"? Do we look solcly at the state as the definer of culture? To dominant elites". Or do we look as well at "traditional" groups within societies? From a legal perspective, the central issue here is one of legitimacy, the legitimacy of the state govermment which seeks to define a "national" culture.
A second issue is whether cultures can change. The organic symbol of the tree suggests that cultures are dynamic, that they are influenced by other cultures. and that they interpenetrate ${ }^{36}$ In other words, cultures can change through both intermal and external forces. This is true for both Western and non-Western cultures. Canada has been reshaped through inmigration and political attachments io multiculturalism, just as African and Asian cultures have been reshaped through colonialism and The dominance of the Western media ${ }^{37}$ Culwural "purity" is a nonscnse, but it seems to be a convincing nonsense for nationalist around the globe, and in our own backyard.

\section{Clash of Cultures?}

This brings me to the so-called "clash of cultures" and its import for contemporary humanrights claims. In June of 1995 , the Voice of Vietnam broadcast excerpts from an article in the army newspaper entitled "Human Rights: A Precious Tree and a Soil to Grow It. In" in which the following comments were made: "The ways in which the human rights offensive of the Western countries has been incensified have caused many people to worry that this issuc could be the greatest source of ideological and cultural conflict in decades to come ..." ${ }^{38}$ This article is typical of the rhetoric that has emerged over the last few years concerning a supposed clash of cultures between "The West" and "The East. (or beivesn "The North" and "rhe South"). One of the most articulatic proponents of the clash is Kishore Mathbubani, the permanent secretary of the Ministry of Forergn Affairs of Singapore. in a series of articles published in leading journals he has documented the collapse of the West, both in terms of its economy and its social structures. He has linked this collapse to Western decadence, which in turn he relates to an overemphasis upon human rights, an exaltation of the individual at the expense of society. ${ }^{39}$

II me semble que ce conflit a été excessivement dramatisé et manipulé politiquement dans le but de protéger certains États, et surtout les élites de ces États, dun examen international rigoureux. La description même de ce pseudo-conflit cst peu nuancéc en ce qu'elle se base sur un portrait caricatural des valeurs occidentales et non-occidentales. Permettezmoi de vous citer quelques exemples.

As concerns the caricatured portrayal of Western values, it is important to note that contrary to the evaluations offered by some interested observers. 
Wistern values are not unremittingly individualist. Inciced, thore are significant strains of Western philosophy in which deep concern is expressed about the proper relationship between individuals and society. I am alluding. of course, to European and Canadian social democracy and to the profound communitarianism of such influential thinkers as Charles Taylor and Alasdair Macintyre. ${ }^{40}$ Furthermore in all Westcrn socleties lmiations on individual rights carn be and are justified. The European Convention for the Protection of Human Rights and Fundamental Frecdoms continins an express linuitation cause. ${ }^{43}$ as does the Canadian Charter of Rights and Freedoms, ${ }^{42}$ to offer but two examples.

One must also be careful not to treat as ixactly commensurate "Western values" and American constitutional law, a mistake that is often made by cultural critics of the West. In many respects, U.S. domestic law is not an adequate exemplar for international human-rights standards. In the area of freedom of expression, for example, the failure to imposo significant limits within the Cnited States upon violent pornography and hate propaganda is not mirrored in all other Western societies. Nor is it accurate to view the human-rights movement as dommated by the United States. Civil libertres and human rights have grown in importance within the Latin American region since the demise of various dictatorships. South Africa has adopted a leading role in the promotion of civil and political rights, most recently in its advocacy of strong actions against the Nigerian dictatorship. The most forceful intrusion upon traditional notions of state sovereignty is found in the European. Convention, ${ }^{43}$ not in an American text.

Finally. when portraying Western values, it is important not to trivialize the notion of human rights. It is not fair or accurate to blame Western "decadence" solely on a felish for rights. For example violent pornography is not treated as a right in most Western societies, even though it is widely available in some. In any event, violent pornography is also produced, distributed and consumed extensively in the Western world.

As concerns non-Western (usually describec as Asian or african) values, one should note that they are not unremittingly communal or social in orientation. In societies as disparate as Singapore, Nigeria and Malaysia, individual achievement, both academic and financial, is widely appreciated. The no- tion of entrepreneurship is expressly upheld as an important social value, even though entrepreneurs arc classic individualists. An astute Singaporean observer has noted that liberal and universalist philosophical strands can be found "in the vast body of Asian culture and within classical Confucian thought., "44

One must: also be careful not to adopt a superficiai assumption that particular values are shared by all Asians or Africans. During the ninetcenth and carly twentieth centuries. Western scholars of Asia oftcu siccumber to "orientalism," the attompt to draw a homogenous, and typically negative, picture of the world to the east of Europe ${ }^{45}$ It strikes me that some advocates of Asian or African values are now participating in the same counterintuitive exercisc, but seekng to put a iniformly positive gloss on "indigenous" cultural artifacts. ${ }^{46}$ For example. the use of corporal punishment in Singapore is justified as an example of social discipline rooted in the Asian values of deference to authority and a desire for social stability and cohesion. Yet this practice is not matched by any similar state-sanctioned punishments in India or Japan. Indeed, it could be argued that corporal punishment is itself a Western imposition, a "value" inherited from the British. ${ }^{47}$ It is ironic to attack Western values using "Asian" examples actually drawn from Western cultural practices. No culture is prisine and monolithic, and it behoves us all to admit the interplay of values and practices that has shaped and continues to shape the overlapping cultures of the contemporary world.

Some of the Asian or African values that are upheld as admirable are frankly irrelevant to a discussion of human rights. There is simply no point of disagreement as between the West and the East on the theoretical importance of the family or of hard work. The fact inai thesc values may not universally he acted upon is not related primarily wo the socially wrakening effects of human rights but to the frailty of the human will.

Finally, and perhaps nuost cuniroversially, proponents of Asian or African values uften seen to have trouhle distinguishing between social or community values and rules that are simply imposed by an authoritarian nation state. It is odd that in a purported attumpt. to support indigenous Asian or African values, state power should be promoted, as the state itself is in large measure a Western imposition. In the name of the collertivity, states can actu- 
ally stifle the traditional community. It seems to me that true communitarianism implies consensus that should not require authoritarian state control, such as administrative detention, widespread censorship and limitations upon the emergence of civil society

\section{Conclusion}

And se I return to the work of F.R. Scott for guidance. How might we move beyond the clash of culures, to find "the fertility of love" experienced on Kanbawza Road? First, we require some honesty and humility on both "sides" of the argument We need to sit on our heels and level our eyes.

I believe that it is helpful to admit frankly that the language of rights is Western in its philosophical roots. But I would then ask what underlies this language. It seems to me that the goal of human freedom and the desire to promote physical, intellectual and spiritual development are values shared by Asian and African peoples and governments, as well as by Western peoples and governments. Furthermore, given the predominance of the interstate system, we are simply "stuck" with a Western language of human rights; it is the language that has inspired all the relevant international instruments.

Bien que le langage des droits de la personne soit d'origine occidentale, il est possible d'établir certames analogies culturelles. N'est-il pas possible d'envisager une terminologie indigène, soit africaine ou asiatique, pour exprimer le respect des individus et des groupes?

If we are to succeed in bridging the so-called clash of cultures, it will also be important to listen 60 diverse voices within Asian, African and Western societies. We need to put ourselves in positions where the plurality of perspectives can be heard. iNo society has a completely homogenous philisophical tradition. Moreover, governmental legitimacy is a relevant issue to raise in some cases. For example, should one really listen to the current government of Nigeria as it seeks to define and limit a monolithic Nigerian culture? Many groups within societies may challenge the governmental asserion of cultural specificity. These groups deserve attention. ${ }^{48}$

Finally, Western proponents of human-rights values must exercise some modesty. Ramundo Panikkar wisely cautions human-rights advocates not to evaluaie uncritically "one cultural construct with the catcgories of another." 49 Human rights is a complex idea with differng ernphases even as between various Western societies. ${ }^{50}$ Only with appropriate humility and self-doubt can true dialogue be encouraged.

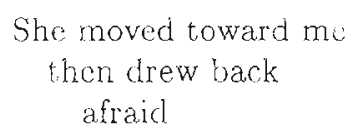
She undersiood the rit ual
taught in lier family.
but never dreamed a foreign giant might need her blessing
Seeing her torn
between faith and fear ï sat down on my heels
Burmese fashion
levelling my eyes with her eyes
At once her fear vanished
she smiled at me
her little hands
dipped the sprig in the bowl and touched me with the fertility

of love

\section{Notes}

1. J.K. Gordon, Address (F.R. Scott Memorial Service, McGill University, 18 February 1985), reported in Faculty of Law Newsletter (Faculty of Law, McGill University) May 1985 at 7.

2. F.R. Scott, "Creed" in The Collected Poems of F.R. Scott (Toronto: McClelland \& Stewart, 1981) [hereinafter Collected Poems] 89 at 89 ( $\ell \ell$ 3-4).

\section{Gordon, supra note 1.}

4. F.R. Scott, "A Lass in Wonderland" in Collected Poems, supra note 2, 264 at 264 ( $\ell$ 1). Scott defended D.H. Lawrence's Lady Chatterley's Lover against obscenity charges in Brodie v. R., [1962] S.C.R. 681, 32 D.L.R. (2d) 507, rev'g [1961] B.R. 610, 36 C.R. 200 (Que Q.B.).

5. Roncarelli ?. Duplessis, [1959] S.C.R. 121, 16 D.L.R. (2d) 689, rev'g [1956] B.R. 447. 
6. F.R. Scott. "Spain 1937" in Colelcied Pocms. supra note 2,96 at 96 ( $\ell \ell 13-19)$.

7. F.R. Scott, "Bonne Entente" in Collected Poems, ibid., 256

8. P. R. Scott, "On Kanbawza Road" in Collected Poems, ibid., 120.

9. Within some (lomestic systems of law, international human-rights standards find solid support in national legishation and practice, which in turn leads to relatively effective implementation. But this implementation is haphazard and completely inconsisicnt betweon various stalcs. It also remanns largely outside the reach of any compulsory international scrutiny

10. The C.J. cannot in any way be blarned for this mactivity which is due to the limitations of its Jurisdiction and the firm desire of most states to preclude the I.C.J. from hearing humant-right cases. On the jurisdiction of the T.C.J., see S Roseanne, The World Court: What It Is and How It Works. jth rev. ed. (Dordrecht: Martinus Nijhoff, 1995) att $81-110$

11. 19 December 1966. Can. T.S. 1976 No. 47. 999 U.N.T.S. 171 [hereinafter I.C.C.P.R.].

12. 19 December 1966, Can. T.S. 1976 Noo. 47, 999 U.N.T.S. 3.

13. 1 March 1980, Can. T.S. 1982 No. 31, 1249 U.N.T.S. 13

14. 19 December 1966, Can. T.S. 1976 No. 47 (3845). 999 U.N.T.S. 302 Thereinafter Optional Protocoli.

15. Sec ibid., art. j(4).

10. High Commissioner José Ayali Lasso has kept a low profile since his appointment and has managed to avoid all public controversy. a singular achevement given the politicized nature of human-rights claims and debates.

17. See e.g. the Canadian government's policy towards China. At the 1996 Liberal Party convention. Prime Minister Jean Chrétien responded to questioning concerning China in the following terms: "If you want us to be the only country in the world boy- cotting Chnna, fine. But we will lose a lot of business. a lot of jobs" (quoted in R. Mickleburgh, "Clina Relentless in Pursuit of Critics" The [Toronto] Globe and Mail (28 October 1996) Al at Al1

18. Charter of the Cinited Nations, 26 June 1945. Can. T.S.1945 No. 7, 59 Stal. 1031, 145 U.K.F.S. 805, preanible \& ants. $1(3), 13(1)(b), 55(c) \& 62(2)$.

19 Countrues usually sign and ratify international hninan-rights instruments with weak cnforcenent mechanısm.s. For exaruple. out of the $13 \%$ countries that have antified the L.C.C.P.R. (supro note 11), only 42 have recognized the comper cucc of the Human Rights Comunitee under article 11. Eightrynine countries have ratified the Optional Protocol supra note 14 (see United Nations, Human Rightits - International Instruments: Chart of Ratifications as at 30 June 1996 (New York. 1996) at 10-11 (UN Doc. ST/HR/4/Rev 14. Sales No. E87.XIV.2) ?

20. For a discussion of "respect for persuns" as "I generative logic for human-rights norms. sec M. Somerville, "The Right to Healuh Care: A Humar Rights Perspective" in j. Mann \& C. Dupuy. eds., SIDA, santé et droits de l'Hommt./AIDS. Health and Human Rights (Veyrier du Liac, Switz: La Fondation Marcel Mérieux, 1993) 75.

21. S. Parker. "How Can 'Rights-Talk' Help Children? An Academic Perspective" in P. Alston \& G. Brennan, eds., The UN Children's Convention and Australiu (Canberra: Humain Rights and Fqual Opportunity Commission, A.N.U. Centre for International and Public Law, Australian Council of Social Servicc. 1991) 16 at 18: see also C. Sheppard. "Caring in Human Relations and Legal Approachics to Equalit.y" (1993) 2 N.J.C.L. 305.

22. GA Res. 217A (III), UN GAOR, 3d Sciss. Supp. No. 13, UN Doc. A/810 (1948) 71 heremaften Universal Declaraizon]. The balancing required under the terms of the Unmersal Decioration is evident in article 29, paragraplis (1) and (2).

23. Professor Humphrey outlined the history of the Universal Declaration in J. Humphrey. Humom Rights and the United Nations: A Great Adventure (Dobbs Ferry, N.Y.: Transnational 1984). The MCGill Law Journal recently dedicated a special issue on international human-rights law to his momory (see (1996) 41 McGill L.J. 739-946). 
21. This is not i,o say that other cultures have remaned aloof from human-rights debates nor that conceptual contributions have been the oxclusive domain of Western thukers. For a sophisticated reading of African human-rights evolution and contrbutions to the global debate, sec F.A. El-Obaid \& K. Appiagyei-Aina. "Hunuan Rights in Africal A New Perspective on Zinking the Past to the Present" (1996) 41 Mrofill L... 819.

25. Sce 1. Parlin. Two Concepts of Liberiy: An Incugura! Lecture Deliused Before the Lninersity of Oxford on 31 October 1958 (Oxford: Clarendon. Press, 1958); and for commentary on Berlin's contribution, sec A. Ryan, ed. The Idea of Frecdom: Essays in Honour of Isaiah Berlin (Oxford: Oxford Universlity Press, 1979).

26. This approach was particularly characteristic of the Reagan arluinistration's engagement with intermational human rights. See c.g., J.J. Kirkpatrick, The Reagan Phenomenon - and Other Speeches on Foreign Policy (Washington, D.C.: American Enterprise Institute for Public Policy Research. 1983). passim.

27. See C. Scoti, "The Interdependence and Permeability of Human Rights Norms: Towards a Partial Fusion of the International Covenants on Human Rights" (1989) 27 Osgoode Hall L.j. 769: J. Humphrey, "International Bill of Rights: Scope and Implementation" (1976) 17 Wm. \& Mary I. Rev. 527; and S. Toope, "The Convention on the Rights of the Child: Implications for Canada" in M. Freeman, ed., Children's Rights: A Comparative Perspectin (Aldershot, U.K.: Dartmouth, 1996) 33 at $35-38$.

28. See K. Vasak. "Les différentes catégories des Droits de l'Homme" in A. Lapeyre, F. de Tinguy \& K. Vasak, eds. Les Dimensions Universelles des Droits de l'Homme vol. I (Bruxelles: Bruyant, 1990 ) 297; see also K. Vasak, "For the Third Grileration of Human Rights: The Rights of Solidarliy" (Inaugural Lecture to the Tenth Study Session of the International Institute of Human Rights, STrasbourg, 2-27 July 1979) [unpublished], cited in P. Alston, “A Third Generation of Solidarity Rights: Progressive Development or Obfuscation of International Human Rights Law?" (1982) 29 Netherl. Int'l L. Rev, 307 at 307 n.
29. See Vasak. "Les différentes catiogories des Droits de l'Hormme," ibid. at. 302.

30. Sce bid

31. Sec Unimant Decharalion supra note 22: K. Vasak, "Ponr une Trosieme Génćration des Droils de l"Hommo" in C. Swinarski. cd.. Stur ies and Essays on Internatronal Humanitarian Law and Red Cross Principles in Honour of Jum Pictet (The Hague: Martinus Nijholf 1984) 837. See also Declaration on the Right to Development, GA Res. 11/128. UN GAOR, 41st Sess. Supp. No. 53. UN Doc. A/11/53(1986) 186

32. See Vasak. "Ios différentes catrgories des Droits de l'Homme," supra note 28 at 303 . Keba. Vibaye also included the right to peace, the right to a clean environment and the right to development within the third generation of rights (see K. Mbaye, Les droits de lhomme en Afrique (Paris: A. Pedone, 1992) at $184-211$ )

33. R. Preiswerk, "The Place of Inter Cultural Relations in the Study of International Relations" (1978) 32 Y.B. of Worid Aff. 251 at $25 \mathrm{i}$

34. C. Grertz, Interpretation of Culture (Now YOrk: Basic Books. 1973) at 89

35. I am indebied to Kalpana Das and Rober't Vachon of the Montreal Intercultural Institute for this cvocative orgunic metaphor.

36. See A. MacIntyre, Whose Justice? Which Rationality: (Notre Dame, Ind: Universify of Notre Dame Press, 1988) at 12; A. An-Na'im, "Conclusion" in A. An-Na'im, ed., Human Rights in Cross-Cultural Perspectives: A Quest for Consensus (Philadelphia: University of Pennsylvania Press. 1992) 127 al 432

37. See E. Said, Culture and Imperialism (New York: Alfred A. Knopf, 1993) at 37-39, 291-303

38. Voice of Vietnam radio broadcast, 5 Jute 1995. rebroadcast on the internet, Southeast Asia Discussion List (seasia-l@imsu.edu) 14 Junc 1995.

39. See $\ell . g . ~ K$. Mahbubani, "The Dangors of Decadence: What the Rest Can Teach the West" (1993) 72:4 Foreign Aff. 10: K. Mahbubani, "The United States: 'Go East. Young Man'" (1994) 17:2 
Wash. Q. 5; K. Mahbubani, "The West and the Rest" [1992] Nat'l Interest (Summer) 3.

40. Sec A. MacIntyre, supra note 36; C. Taylor. Sources of the Self: The Making of the Modern Ideniity (Cambride, Mass: Harvard University Press. 1989).

41. See European Convention for the Proteciion of Human Rights and Fundamental Freedoms. 1 November 1950. Eux. T.S. 5, 212 U.N.T.S. 221. art. 15 hereinafter European Conventionj.

12. Sce Canadian Charter of Rights and Freedoms. Part : of the Constitution Act. 1982, being Schedule B to the Canada Act 1982 (U.K.), 1982, c. 11, s. . .

43. Sec c.g. Sections III and IV of the European Convention, supra note 41 , which establish the jurisdiction of both the European Commission of Human Rights and the European Court of Human Rights.

44. S. May, "Human Rights, Culture and the Singapore Example" (1996) $41 \mathrm{McG}$ cill I.J. 743 at 758.

45. See E. Said, Orientalism (New York: Vintage Books, 1978).

46. Edward Said, ibid, at 325, writcs, "the modern Orient... participates in its own Orientalizing."

47. Sec Tay, supra note 44 at 754 . Tay also enphasizes, appropriately in my view, that given the increasing interplay amongst cultures, "indigenous" traditions are often mélanges of cultural strands from diverse traditions, and that tradition itself may often be "invented", serving as a solace to populations coping with the stress of deep social change (ibid. at 762-63, 768-71). See also R. Falk. "Cultural Foundations for the International Protection of Human Rights" in An-Na'im, ed. supra note 36. 44 at 46 . On the social invention of tradition, see E. Hobsbawm \& T. Ranger, eds., The Invention of Tradition (Cambridge, U.K.: Cambridge University Press, 1983).

48. For $\lambda$ subtle discussion of alliances of equality between internal and external cultural critics, see K. Savell, "Wrestling With Contradictions: Human. Rights and Traditional Practices Affecting Women" (1996) 41 McGill L.J. 781.
49. R. Panikkar, "Is the Notion of Human Rights A Western Concept?" (1982) 120 Diogenes 75 at 88.

50. The example of capital punishment, varyingly rejected or embraced across Western societies, comes to mind. 


\section{Print Culture and English-Speaking Quebec}

\section{by Peter F. McNally}

The role of English-speaking Quebecers in the cultural development of both Quebec and Canada generally tends to be overlooked, but in fact is too important to be ignored. This article discusses Anglophone Quebec's contribution to print culture in three time-periods: 1764-1820,1820-1890, and 1890 to the present. However, many important aspects of this culture still require serious investigation or synthesis.

Le rôle des Québécois anglophones dans le développement culturel du Québec et du Canada a généralement tendance à ne pas être pris en considération, alors qu'il est trop important pour être ignoré. Cet article est consacré à la contribution des anglophones du Québec à la culture imprimée à trois époques: 1764-1820, 1820-1890 et 1890 à aujourd'hui. Il a reste toutefois que plusieurs aspects importants de cette culture doivent faire l'objet de recherches ou de synthèses sérieuses.

Anglophone Quebec's contribution to print culture in Quebec and Canada is in danger of falling amor.g competing schools of opinion and, therefore, of becoming invisible. For some commentators, Qeubec's anglophone culture is an irritating anomaly which distracts from the definition of the province as an exclusively French-speaking territory; for others, anglophone Quebec is viewed solely within a broader Canadian anglophone context, devoid of reference to the unique aspects of Quebec heritage; for yet others, anglophone Quebec is best ignored because of the complexity involved in dealing with such a difficult issue. Although these generalizations, like all generalizations, are overstated and admit to important exceptions there is a persistent sense, in some quarters, of anglophone Quebecers having been orphaned among competing solitudes. McTernan's two volume bibliography of French-language Quebec imprints, in the British Library (1992-93), ${ }^{1}$ contributes to this sense. For most commentators, however, the role of English-speaking Quebecers in the cultural development of Quebec specifically, and Canada generally, is too important to be ignored; clearly no history of Canadian print culture can afford to overlook anglophone Quebec.

\section{To 1820}

Anglophone interest in Canada generally, and Quebec specifically, began during the French regime, as the bibliographies of Waldon ${ }^{2}$ and Waterston ${ }^{3}$ make clear. There having been no printing press in New France, only in 1764 - with the beginning of the English regime - was printing introduced into the new province with a dynasty of English-speaking printers who dominated Quebec City's printing for the next 60 years: William Brown and Thomas Gilmore (1764-1773), William Brown (1773-1789), Samuel Neilson (1789-1793), and John Neilson (1793-1822). ${ }^{4}$ Although Canadian printing began in Halifax in 1751, Quebec City with its larger population and economic/political importance soon became the centre of printing in late 18th and early 19 th century Canada. While slightly more than $50 \%$ of the books published in Quebec between 1764 and 1820 were in French, a press having been established in Montreal in 1776, the fact is that only 1,100 or so titles were actually printed. Anglophone titles accounted for $27 \%$ and bilingual English/French titles for $18 \%$.

Recent studies have shown that the bulk of 18th 


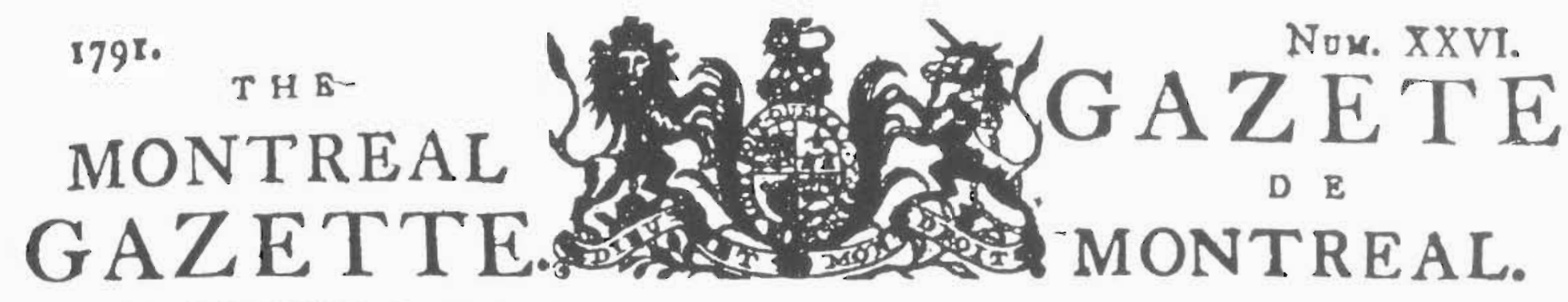

T H. U.R S D A Y, J O * 16.

JEUDI, 16 IU I.

\section{U B L I N,}

Fazeary to.

A CTRCUSSTANCE of a mol dreadful nature hes throfpired ichin thefe few days:-Aright of two ago * a very lart hoos, iwa perfons, feemingly. geotemen, drove themfelves ont in a potichaife to Charchtown? where tbere is a berial places, with a dead body contined up in the carriage. They rapped up ibe graveligger, and told bim, that aoder the difguife of oight they had broaght oot 'or to be interned, whicb in the day tiroe, they upprebended, mighe be arreted for debe, and foe the buriel of which be thould bare a grioes.

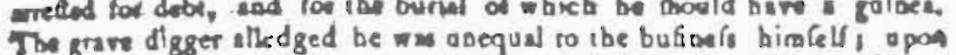
bich thele perloos faid ibey would give bim balf a guidea for an affenots - hich wa agreed $\mathrm{m}_{3}$, and the corplo was accordingly left with ibe gravedever. The later immediately called up 20 effilat i bat apon agreeent they determiaed upon pouponing the bafoefis till day light. Whon thr arofe in the morulog, curiolity arged them 10 open, ibe coffin, whiction fo doing Ul thocking ia bentiond ther found the body of a

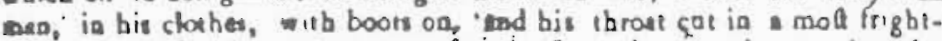
ful manper. In bis porkets were found, fx guiness and a watch; for the penperty of which thefe two perfone differed, or elfe the tranfadion would probably have nerer come to ' $\mathrm{T} g$ ht. The boly remaias at this piace to be ouned, which as yet, has noo iaked piace: wor bar any thing ocorred which ca: lead in a teovery. Every $c 5$ : wiroefs of ibis borrid, fou! rastactiva, is prayin: fot the developecoe.n of the cruel gerpetrator.

\section{O N D O N, Fistustr 10.}

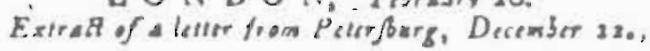

At a Protedant metting in Strofourg, the following prayer is offered Ip ewice a day, foe the natiooal atjerabliv:

"Almighty Gad! animate by thy power the depatict of the Franks! Cherion, in their beates.' in defatigable ieal wich is so deseftary to acselarate the accomplimment of oor welfarol be their quidel be their
D B P A I I, le to Ftrriet.

Sleari da Mond fur.

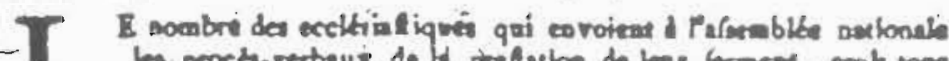

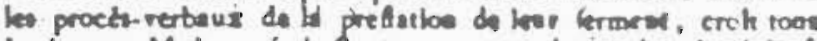

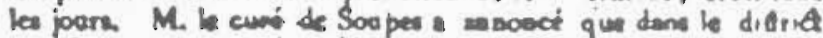

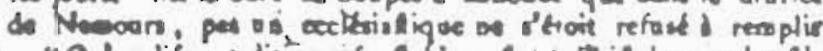

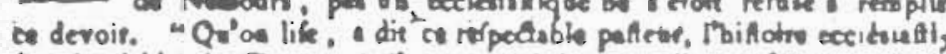

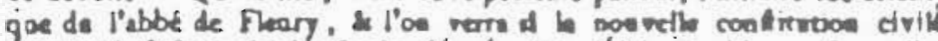

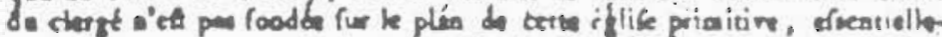

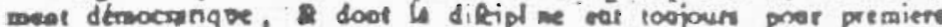

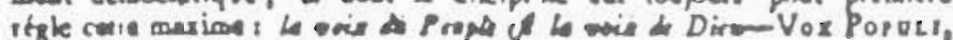
Vox Des.

Ledtpart des Merdimes, tantel do Rol, fiese toeve la capitale en

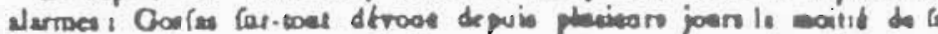

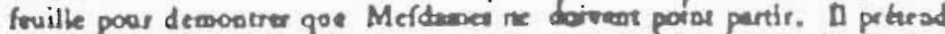

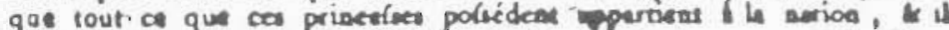

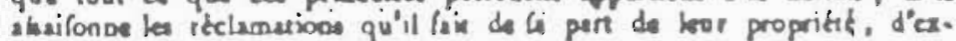
prefsion qui ne foot pas trab bonnties.

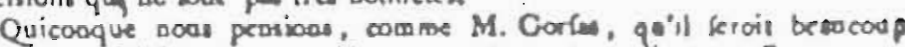

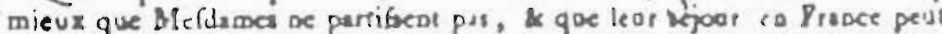

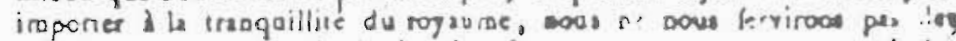

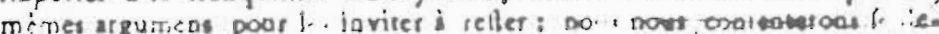

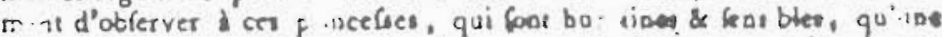

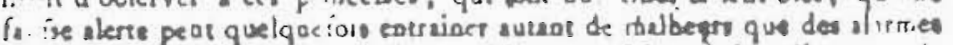

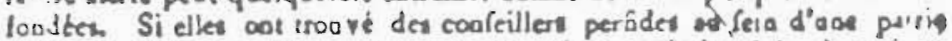

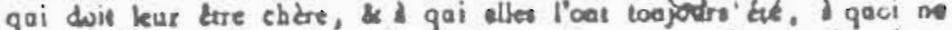
doivens-ilkes pas s'attendre; quad elles as feroor entositeo que de pretres faratiquea \& enoemir d'une contitutior asi a's enjevé aux misifrea de

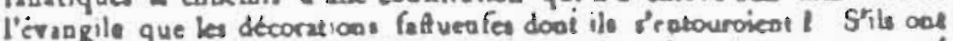

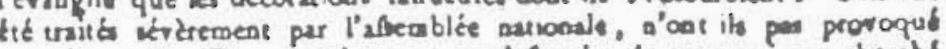
re traitement? Dans tous les cas; ce n'elt point de cour qui oset cherchs

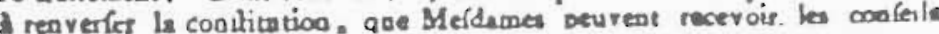


century Canadian printing revolved around newspapers and job printing such as printed forms, handbills, and broadsides. ${ }^{5}$ Of the seven newspapers published in 18th century Quebec, only two endured over time: the Montreal Gazette (initially francophone) and the Quebec Gazette. Both were bilingual publications, at various points in their history, before becoming unilingually English. Of the two magazines published in 1.8th century Canada, one appeared in Quebec, the bilingual Quebec Magazine, 1792-1794. The bulk of handbills and printed forms appeared in English.

Concerning the diffusion of publications in 18th century Quebec, both Montreal. and Quebec City had libraries dating from the French regime, all of which were attached to religious institutions, such as hospitals and colleges, and none of which was designed to be available to the general public. The first to be open to the general public were bilingual subscription libraries, whose collections were more or less evenly divided between English and French language books: the Quebec Library opened by Governor Haldimand in Quebec City in 1779, and the Montreal Library opened in $1796 .{ }^{6}$ There is no evidence of bookstores in 18th century Quebec, except for those attached to printing establishments, and which probably also doubled as lending libraries. Personal libraries of significance emerged at an early date among anglophones.

\section{III. $1820-1890$}

Although John Neilson continued to dominate Quebec City printing well into the 19th century, the focus of Quebec's anglophone publishing after 1820 switched to other parts of the province such as Three Rivers, and the Eastern Townships. ${ }^{7}$ Montreal, which had established itself as the economic and cultural metropolis of British North America, and had an anglophone majority between 1831 and 1865, emerged as the centre for English-language publishing not only in Quebec but all of Canada. This hegemony, which would endure up to 1890 , was based upon both original publishing and unauthorized reprinting of British and American books, for which royalties would not be paid. The chaotic and uncooperative nature of Canadian, British, and
American copyright laws both permitted and encouraged such anarchy.

Montreal's two leading publishers were Dawson Brothers and John Lovell. Lovell was particularly significant, becoming Canada's leading publisher in English and French, as well as developing a significant presence in the United States. Even today the firm continues to enjoy an important role in the publishing of directories and other reference works. Dawsons was particularly active in publishing scholarly works, including the books of Sir John William Dawson, McGill University's great principal and Canada's leading intellectual/scientist of the 19th century. In time the Renouf publishing company would evolve from Dawsons. Although both Dawsons and Lovell indulged in issuing unauthorized editions of British and American works, they also printed authorized editions in co-operation with various foreign authors and publishers. As a reflection of its cultural and economic dynamism, Victorian Montreal became the leading Canadian publisher of English language legal and medical titles. ${ }^{8}$

English language periodical and newspaper publishing in Quebec during this period was particularly important. Montreal newspapers such as the Gazette, Herald, Star and Witness exerted national influence. ${ }^{9}$ Local English language newspapers could be found in Quebec City and other centres across the province. Montreal magazines played an considerable role in the development of an indigenous English Canadian tradition of periodical publishing. The Literary Garland (1838-1851) was the country's first literary journal, in English or French, to enjoy real longevity. Snow Drop (1847-1853) was the earliest Canadian children's magazine. ${ }^{10}$ Following Confederation, the Canadian Mlustrated News (1869-1883) was the young nation's first illustrated magazine and. the first in the world to make use of half-tone technology in reproducing illustrations. ${ }^{11}$

In the diffusion of printed materials, 19 th century English-speaking Quebec also displayed verve and energy, with Montreal being the focal point of activity. Of the approximately 165 libraries that emerged in Montreal during the century, around $50 \%$ were anglophone. ${ }^{12}$ The most significant were probably the McGill University Library, the Fraser-Hickson 


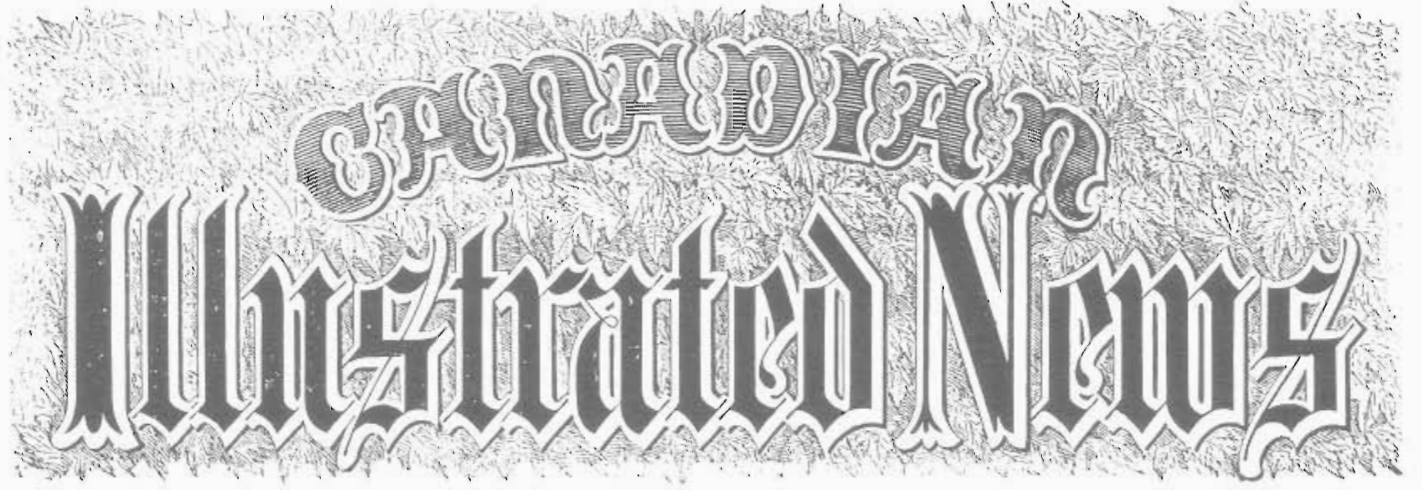

VoL. L. - No. 27.]

MUNTREAL, SATURUAY, MAY 7, 1870.

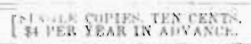

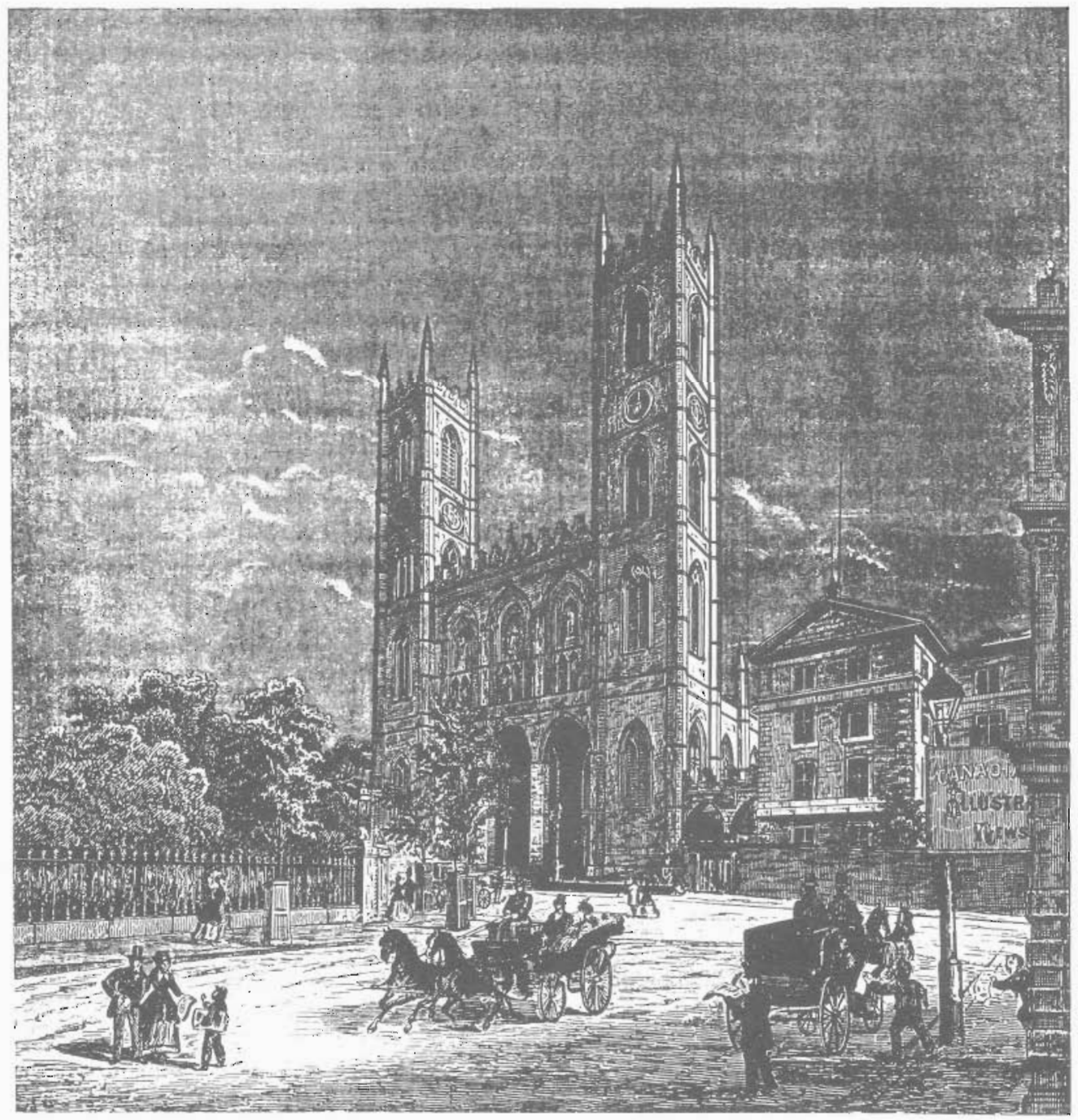

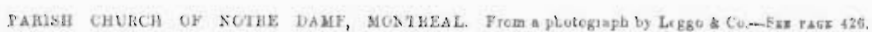


Library and the Mechanics' Institute Library. ${ }^{13}$ Important private collectors emerged during this era, of whom Peter Redpath is probably the most important, with his outstanding collection of 17 th, 18th, and 19th century British Tracts given to McGill University. Although the community was largely insulated from the more extreme aspects of the lay/clerical struggle that tore apart the francophone community during the fight over the library of L'Institut canadien, this struggle would effectively thwart any attempts to found a public library in Montreal until the next century. A. large number of anglophone bookstores developed during the 19th century, but have received little if any study.

\section{1890 to the Present}

In the $1890 \mathrm{~s}$, with the harmonization of copyright laws and protection in Canada, Britain, and the United States, there ended the unauthorized reprinting, without royalties, of books published in the three countries. This coincided with the shift of Canada's English language publishing centre from Montreal to Toronto, where both indigenous local publishers and branch offices of British and American firms established themselves. Although some local anglophone publishers, such as Lovell and Dawson/Renouf, have continued in Montreal from the 19 th century they have concentrated, like most of the English language publishers established during the last one hundred years or so, upon specialized markets rather than national mass markets. Virtually all anglophone publishing over the last century has been concentrated in Montreal. That said, publishing and other aspects of English language print culture in the province continue to maintain themselves despite the shrinking size of the community and the relative economic decline of Montreal.

At the turn of the century, the McGill University Library inaugurated the reprint series, the McGill University Publications, which is an important precursor of academic publishing in this country. ${ }^{14}$ In fact, the series is the direct ancestor of the McGill University Press, established in 1960 and reorganized as the McGill-Queen's press in 1968. Run jointly by McGill and Queen's University, the press is one of the largest and most pres- tigious academic publishers in Canada. Other notable general anglophone publishers were/are Louis Carrier/Mercury (c.1920-1931), Harvest House (1960-), Vehicule (1973-), Eden (1980s), Robert Davids (1992-).

In addition, several specialized presses have developed such as Tundra (children's, 1967) and Black Rose (left wing politics, 1970-). Reference should also be made to the large number of small literary presses appearing in Montreal during and after World War II: First Statement, Contact, Delta Canada, New Delta, Muses's Company, Guernica, and NuAge, to name a few. In fact, for a period during the 1950s and 60s Montreal may well have been English-speaking Canada's literary/poetry publishing capital. Finally it should be noted that newspapers will publish books on occasion, and that a host of minor imprints have risen and fallen over the decades. At the very least, English-speaking Montreal continues to be a significant regional publishing centre with some national impact.

Periodical publishing in English has undergone great change over the past one-hundred years. The McGill University Magazine (1901-1906) and its more famous successor the University Magazine (1907-1920) were amongst the most important Canadian journals of informed opinion and general culture in the first two decades of this century. ${ }^{15}$ From c.1950 to 1979, Weekend Magazine was published by the Montreal Star as a glossy pictorial weekend supplement that appeared in newspapers across the country and was read weekly by millions of Canadians. For some decades after World War II, Time Magazine published a Canadian edition in Montreal. Since 1958, Reader's Digest has been publishing its Canadian editions - English and French - in Montreal. Otherwise the only periodicals published in Montreal that have enjoyed national prominence have been literary titles such as the McGill Fortnightly (1920s), and others issued by the small literary presses mentioned earlier. A publication devoted to the study of print culture in Englishspeaking Quebec is Fontanus, from the Collections of McGill University, 1988-. Newspaper publishing has continued to be a major factor in the anglophone cultural presence. Although the number of dailies has steadily declined during this century, so that only two now remain, the Montreal Gazette 

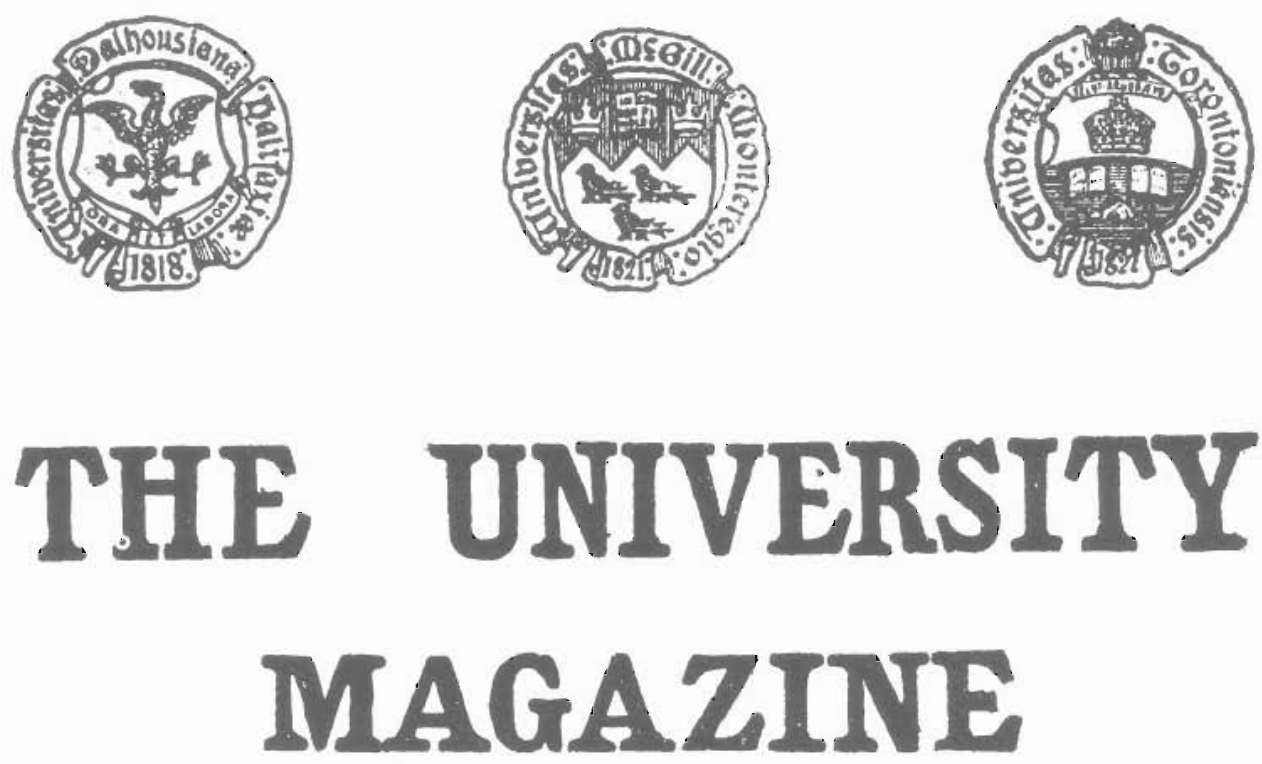

VOLUME VI. 1907

THE MACMILLAN COMPANY

OF CANADA 
and the Sherbrooke Record, many weeklies continue both on the Island of Montreal and elsewhere in the province.

The diffusion of printed material continues to be a central concern of the anglophone community. In 1893 , the province's first specifically designed library building was opened with the inauguration of Redpath Library at McGill University. McGill continues to possess Quebec's largest academic library, with a wealth of research collections - many the gifts of local collectors. Among these research collections are two of particular importance to the study of Canadian print culture: the Canadiana collections and the Colgate Printing Collection. There are a number of other academic libraries at Concordia University and anglophone CEGEPS, or community colleges. The list of Montreal head offices with libraries, which was once sizeable, has shrunk as the city has declined in importance as a financial centre. In 1899, Quebec's first tax-supported public library was opened in the largely English-speaking Montreal suburb of Westmount. ${ }^{16}$ In the early years of this century, McGill operated the Mclennan Travelling Library, which provided books for rural Quebec and the rest of the country until its provincial government grant ceased in 1970. In a province that is only slowly developing a public library system, the anglophone communities are frequently characterized by their libraries. Montreal's Jewish community has developed an excellent library. ${ }^{17}$

In 1904, McGill inaugurated Canada's first formal educational programme for librarianship, which also enjoys the distinction of being the oldest university based programme in the world, outside the United States. ${ }^{18}$ In 1930, it published the first bibliography of Canadian bibliographies. ${ }^{19} \mathrm{~A}$ wide range of English language bookstores can be found in Quebec, mostly in the Montreal region. The Classic Book chain, c.1950-1980, a major force in Canadian retailing, was centered in Montreal. The city has also had outstanding and colourful antiquarian book dealers, of whom Bernard Amtmann was an outstanding example. His Montreal Book Auctions were of national significance through the $1960 \mathrm{~s}$ and $70 \mathrm{~s},{ }^{20}$

As the footnotes will show, this survey has been based upon a relatively narrow research base. That said, many important aspects of Quebec's anglophone print culture still require serious investigation of synthesis: literacy and education, ${ }^{21}$ native peoples, publishers and printers, bookstores and other forms of distribution, censorship, and libraries of all sorts including personal libraries. Attention should also be paid to the print culture of Quebec's ethnic communities, other than English or Frenchspeaking. The real need is, however, for a synthesis of the history of Quebec's anglophone and francophone print culture that respects both their unique and shared qualities.

\section{Notes}

1. D. McTernan, French Quebec: Imprints in French from Quebec, 1764-1990, in the British Library: a Catalogue. London, British Library, 1992$93,2 \mathrm{v}$.

2. F. Waldon, Bibliography of Canadiana Published in Great Britain, 1519-1763. Ottawa, National Library, 1990.

3. E. Waterson, The Travellers: Canada to 1900. an Annotated Bibliography of Works Published in English from 1577. Guelph, University of Guelph, 1989.

4. M. Tremaine, A Bibliography of Canadian Imprints, 1751-1800. Toronto, University of Toronto Press, 1952. M. Vlach, Cataglogue collectif des impressions quebecoises, 1764-1820. Montreal, Bibliotheque nationale du Quebec, 1984.

5. M. Brisebois, The Printing of Handiblls in Quebec City, 1764-1800; a Listing with Critical Introduction. Montreal, Graduate School of Library and Information Studies, McGill University, 1995.

6. P. McNally, "Canadian Library History in English, 1964-1984; a Survey and Evaluation." and "Canadian Library History in French, 1964-1984; a Survey and Evaluation." in Readings in Canadian Library History, ed. by P.F. McNally, Ottawa, Canadian Library Association, 1986. p. 19-39. "Canadian Library Hsitory in English and French to 1964; a Survey and Evaluation." in Readings in Canadian Library History 2, edited by P.F. McNally, Ottawa, Canadian Library Association, 1996. p. 3- 
36.

7. G. Parker, The Beginnings of the Book Trade in Canada. Toronto, University of Toronto Press, 1985. B. Whiteman, Lasting Impressions: a Short History of English Publishing in Quebec. Montreal, Vehicule Press, 1994.

8. G. Baker, Sources in the Law Library of McGill University for a REconstruction of Legal Culture of Quebec, 1760-1890. Montreal Faculty of Law, McGill Unviersity, 1987. J. Connor, "To Advocate, to Diffuse, and to Eelvate: the Culture and Context of Medical Publishing in Canada, 1630 to 1920." Ph.D. Thesis, University of Western Ontario, 1992. C. Roland, An Annotated Bibliography of Canadian Medical Periodicals, 1826-1975. Hamilton, Hannah Institute, 1979.

9. W. Kesterton, A History of Journalism in Canada. Toronto, McClelland, 1967. B. O'Donnell. Printed Sources for the Study of English-Speaking Quebec; an Annotated Bibliography of Works Published before 1980. Lennoxville, Bishop's University, 1985. -Sources for the Study of English-Speaking Quebec; an Annotated Bibliography of Works Published between 1980-1990. Lennoxville, Bishop's University, 1992. C. Cardinal, The History of Quebec: a Bibliography of Works in English. Montreal, Centre for the Study of Anglophone Quebec, Concordia University, 1981.

10. Whiteman, p. 55. M. MacDonald, "Literature and Society in the Canada, 1830-1850" Ph.D. Thesis, Carleton University, 1984.

11. Canada Mlustrated, the Art of NineteenthCentury Engraving. Toronto, Dreadnaught, 1982.

12. Y. Lamonde, "Social Origins of the Public Library in Montreal." Canadian Library Journal, v. 38 , no. 5 (Dec. 1981) p. 363-370.

13. P. McNally, "McGill University Libraries" Encyclopedia of Library and Information Science. New York, Dekker, 1976. v. 27, p. 311-320. E. Moody, The Fraser-Hickson Library, an Informal History. London, Clive-Bingley, 1977. The Mechanics' Institute of Montreal, 1840-1940. Montreal, Institute, 1940 .

14. P. McNally, "Scholar Librarians: Gould, Lomer, and Pennington," Fontanus: from the Col- lections of McGill University, v. 1 (1988) p. 95104; R. Makela, McGill University Library during the Tenure of Charles H. Gould as University Librarian, 1893-1919. Montreal, Graduate School of Library Science, 1974.

15. P. McNally, "Canadian Periodicals and Intellectual History: the Case of the McGill University Magazine/University Magazine, 1901-1920." Bibliographical Society of Canada Papers, v. 19 (1980), p. $69-78$.

16. E. Hanson, "A Jewel in the Park: Westmount Public Library, 1897-1918." Ph.D. Thesis, Indiana University, 1994.

17. S. Gubbay, "The Jewish Public Library of Montreal, 1914-1952." M.A. Thesis, McGill University, 1983.

18. P. McNally, "Fanfares and Celebrations: Anniversaries in Canadian Graduate Education for Library and Information Studies." in Readings in Canadian Library History 2. p. 39-56.

19. M. Higgins, A Bibliography of Canadian Bibliographies. Montreal, McGill University, 1930.

20. J. Mappin and J. Archer, Bernard Amtmann, 1907-1979: A Personal Memoir. Ottawa, Amtmann Circle, 1987.

21. R. Magnuson, A Brief History of Quebec Education: from New France to the Parti-Quebecois. Montreal, Harvest, 1980. 


\section{Canada's Animal Doctor: Duncan McNab McEachran}

\section{by George Thomson}

Duncan McNab McEachran (1841-1924) was an eminent member of McGill University, founder of th: Montreal Veterinary College and the man responsible for introducing quarantine to Canada. After graduating in veterinary science, in 1862 he emigrated from Scotland to Canada, at a time when disease was rife amongst cattle in North America. In Canada he set up a practice, lectured, helped to establish the Ontario Veterinary College and, in 1866, moved to Montreal where he founded the Montreal Veterinary College. The College was the first in Canada to introduce the experimental study of animal diseases. In 1889 it became a faculty of McGill University, but was closed in 1903. Meanwhile, in 1867 McEachran co-authored The Canadian Horse and his Diseases.

A recurring theme throughout McEachran's professional life was the danger of importing diseased cattle. He encouraged efforts to prevent the introduction into Canada of foot and mouth disease and other infectious ailments, and organized (1875) the first Canadian cattle quarantine at Port Levis, Quebec. The U.S. quarantine stations were later remodelled on the basis of McEachran's ideas.

Duncan RicNab McEachran (184-1924), émineni membre de "Univorsité McGill, a fondé le Montréal Veterinary Jollege y'esi à lui que i'on lott 'introdustion a a quarantaine au Janacia. Après avoir obtenu son diplôme en sciences vétérinaires en i862, il a quitté l'Écoss. pour 's Canada à une époque où plusieurs maladies décimaient se béiail nord-américain. Au Canacia, il a ouvert un rabinet, donné des cours, et participé à la creation de 'Ontario Veterinary Coilege. In i806, ". arrive à Montréa où il fonde le Montréal Veterinary Jollege. I7 s'agit àu premier collège anaaien à avoir introàit "étude sxpérimentale des maladies animales. En 1889, le coilège est devenue une des tacultés d̀ l'Université McGil, mais a fermé ses portes en 1903 . En:867, McEachran cosigne The Canadian Horse and his . Jiseases.

Le danger que représentait l'importation de bétail infecté était une nríoccupation constante pour Mc:achran. $I$ a déployé d'importants efforts pour prévenir l'introduction de á fiève aphieuse at d'autres maladies infectieuses au Canada, et organisé (1875) le premier poste de quarantaine pour le bétail à Port Lévis (Québec). Les postes de quarantaine américains s'inspirent directement de ses iciées.

$\mathrm{M}$ awareness of fooc safety. In particular, the concern in Iurope with bovine spongiform encephalopathy (BSE) in beef and the octbreak of Escherichia coli poisoning in Central Scotland through meat products in late 1996, were poignant reminders. Such worries sre not new and were a lifetime obsession of a Scot who is almost unknown in sritain and has not received the recognition he ceserves in his adopted country, Janada: Zuncan ivic ${ }^{\top}$ ab ilcEachran, an eminent member of Mc ill University, founder of the Montreal "eterinary college anc the man responsible for introducing quarantire to Canaca, and for effecting significant changes to procecures in the 
Winited States.

MicEachran was born in Campbeltown, October 27, 1841, the son of David McFachran and Jean Blackney. He was a direct descendant of an eminent Argyll family that can be traced, through the Chiefs of the Clan McEachran, to Toiseach Ban mac Eachairn, who settled in Killellen, Kintyre about 1150. This ancestry includes Colin, to whom a Celtic cross dating to before 1500 was erected. The family was steeped in rural matters, including farming and blacksmithing. They were also very public-spirited - three of them were bailies. This background must have shaped Duncan McEachran's life. His father was senior bailie in the town for six years.

After his school-days at the Free Church School, Duncan entered the Royal Dick Veterinary College in Edinburgh at the age of nineteen. Apparently he was not persuaded to the medical profession, deciding that doctors were already too numerous, while veterinary science was still in its infancy. Very little is recorded of his student life in the city. He graduated as a veterinary surgeon in 1861, in which year he became a Member of the Royal College of Veterinary Surgeons, and in 1873 he was elected one of its original Fellows.

Nobody knows why he left his native land, but he did so in 1862. He settled in Woodstock, Ontario, where he practised as a veterinary surgeon for about three years. North America was in the midst of a plague that was destroying animals, especially cattle. About 1860, Adam Ferguson, Chairman of the Board of Agriculture for Upper Canada, sent George Buckland, a lecturer in Agricultural Science at Toronto University, to Scotland to talk with Professor Dick of Edinburgh. The consequence of this meeting was that Andrew Smith, a recent graduate of the Dick College and college friend of McEachran, was recommended as a desirable person to lecture in Canada. Smith began his lectures in Toronto in 1862. During the foundation of the Ontario Veterinary College, Smith called on McEachran to assist. McEachran rapidly built up a reputation, lecturing on professional subjects. He talked at farmers' meetings, published in the agricultural press and, together with Smith, wrote The Canadian Horse and his Diseases (McEachran and Smith, 1867). It is said that McEachran and Smith had divergent opinions on veterinary education and that this was the resson for his move to Montreal in 1866. Either this conflict was not as great as supposed or the collaboration on the book contributed to the split. Whatever the reason, McEachran's loss to Ontario was strongly felt. The Board of Agriculture passed a resolution expressing regret at his departure, and he was entertained by a large number of friends at a public dinner.

Almost as soon as he arrived in Montreal, McEachran acquired a circle of influential friends, knowledgeable of his reputation. Under the auspices of Dr. George Campbell, President of the Bioard of Agriculture and Dean of the Faculty of Medicine at McGill University, then a college, and Sir William Dawson, Principal of the University, McEachran established the Montreal Veterinary College on September 26, 1866 with a grant of $\$ 300$ from the Provincial Government. This college was initially situated at the corner of Craig and Bleury Streets, but in 1875 was moved to a new building, built by McEachran at his own expense, at 6-8 Union Avenue. By then, the importance of the college was being recognised and it was awarded a grant of $\$ 1800$ for ten years to accommodate thirteen French speaking and six English speaking students for free education. The college was unique in having separate French and English speaking sections and was the first to introduce the experimental study of animal diseases in Canada. In 1889 it became a, faculty of McGill University with the titie, The Faculty of Comparative Medicine and Voterinary Science. University documents show that "Professor McEachran lectures on Veterinary Medicine and Surgery." Curiously, they also record that "Professor C. MicEachran lectures in Veterinary Obstetrics and Pathology." However, there are no known members of the family that joined Duncan in Canada. In its time the college and faculty were very successful. The Montreal Gazette of March 30 , 1877 reported:

The report of the Miontreal Veterinary College is very favourable to that institution, showing the animals who had received surgical aid to be 1664 horses, 50 cows, sheep, 1 pig, 116 dogs and 5 cats. It is recommended that a grant of $\$ 2000$ be asked from the Government for the appointment of a French Lecturer in the College.

The faculty survived until 1903 when it was closed, largely because of the lack of financial support, having only three candidates in its last year. Cameron (1938) believed that its downfall was due to it setting standards that were too high for its time. 
McEachran retired at the age of seventy to Ormstown, District of Beauharnois, residing at Ormsby Grange, a substantial Quebec mansion where according to the Huntingdon Gleaner, he lived quietly sorting out his records of 60 years and watching the results of his labours.

Duncar McEachran appears to have been quite I a social personality, although he never achieved the international reputation of his colleague Sir William Osler, the great American physician, whose overall achievements were less than those of McEachran. Osler and McEachran became very close social and professional friends, although their characters were quite different. Osler wrote to McEachran:

You are one of my closest and best friendis and If owe a great deal to you for your kind encouragement in my early days.

Osler was introduced to Montreal social life by IVICEachran who wrote:

On my suggestion he became a member of the Microscope Club. This Club was of a combined scientific and social character.

An item in the Montreal Gazette of 30 March 1877 reported:

Mr. McEachran entertained the examiners, successful students and professor to supper in the evening, when a very pleasant time was spert, and Dr. Osler was the recipient of a very complimentary address, accompanied by a purse of $\$ 100$, to aid him in scientific research.

Apart from his practice and professional teaching, Duncan pursued many other activities. In 1875 , he founded the Veterinary Medical Association, of which he was president, in 1877 and later ex-officio Homorary President. For ten years he was Veterinary Surgeon to the Montreal Field Battery of Artillery. He pioneered large scale ranching in Canada, together with Senator Cochrane, establishing the Cochrane Ranch in 1881 of which Duncan was VicePresident in 1883. In that year he became general manager of the Walrond Cattle Ranch Company, of which Sir John Walrond was President. This was one of the largest and most successful ranches in Canada. Duncan was made a Justice of the Peace in 1886 with jurisdiction over the entire Province of Quebec. He acted as an expert judge of hackneys at the National Horse Show, New York in 1891 and 1892 and judged thoroughbred horses at the World's Columbia. Expo in Chicago in October 1893. He was the promoter of the Ormstown Exhibition from 1909. Politically he was a liberal/conservative, but was not active in this respect. Duncan is listed as a subscriber to Cuthbert Bede's Argyll's Highlands (Bede, 1902).

In $1905 \mathrm{McEachran}$ was drawn into one of the greatest, if not the greatest, lawsuits fought in the United States until recent years. The Anaconda Cooper Mining and Smelting Company had been sued by the stockmen of Deer Lodge for two million dollars and a permanent injunction to cease working. McEachran took the case on behalf of the company. The ranchers claimed that their animals were being killed by the fumes from the smelter that was poisoning the hay and grain. The case was heard between 1906 and 1907 at which there were 250 witnesses, 300 examinations and 850 exhibits in evidence, including cartloads of animals, vegetation, photos etc. The records of the case extended to 25,135 pages. The judge took two years to come to his decision in favour of the company.

Duncan McEachran was widely travelled in North America. In 1881, he visited Alberta and the Northwest Territories (the Bow River) via the Missouri River, acruss the plains from Fort Benton in Montana to Morleyville. On his return he published descriptions of the journey (McEachran, 1881) that clearly exhibited his high moral character.

Having three days to wait for our steamer, we made what purchases we required, and took advantage of an offer of a high Government functionary to show us the "city [Bismarck] by gaslight." Our first visit was to a "keno" gambling house, where we stayed but a short time, the disgusting sight of seeing gambling in its worst form, and the foul air and still fouler language soon drove us from the place, none of us caring to stay long enough even to comprehend the game, which was new to us.

He was equally unimpressed by the "opera house".

Ascending the narrow stairway we reached the gallery, which was partitioned off into a row of curtained boxes, in which were seated in lounging attitudes the better-off class dressed in the height of regular fashion, rings and paste diamonds forming a conspicuous part of their dress. These boxes are connected with the stage by a narrow stairway on each side, by which the actresses reached the boxes and spent their time between the acts, being regaled by beer or 


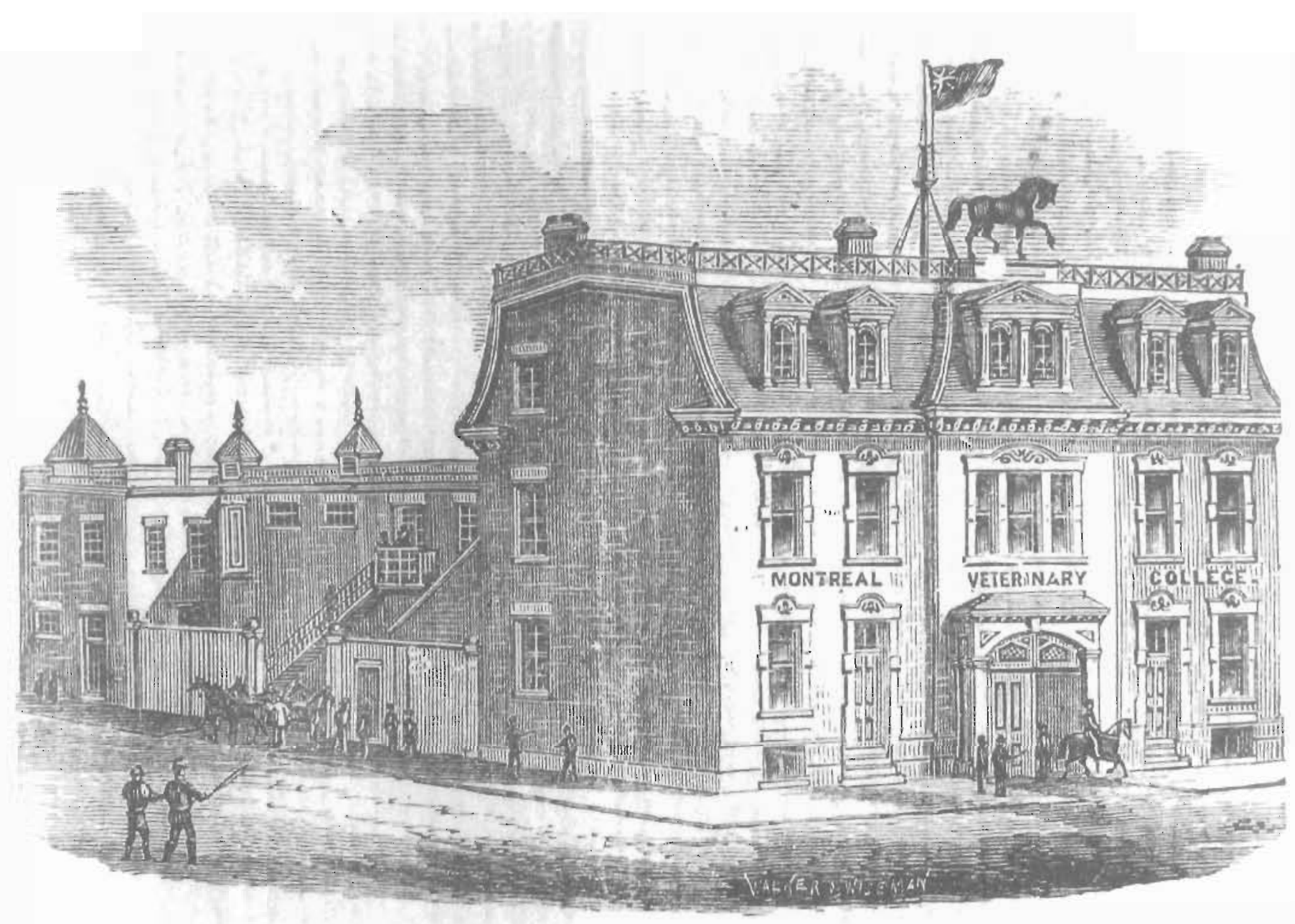

NOS. 6 AND 8 UNION AVENUE, MONTREAL.

Montreall Veterinary College

(McGill University Archives, PR001239) 
Canada's Animal Dortor: Duncan McNab McEachran

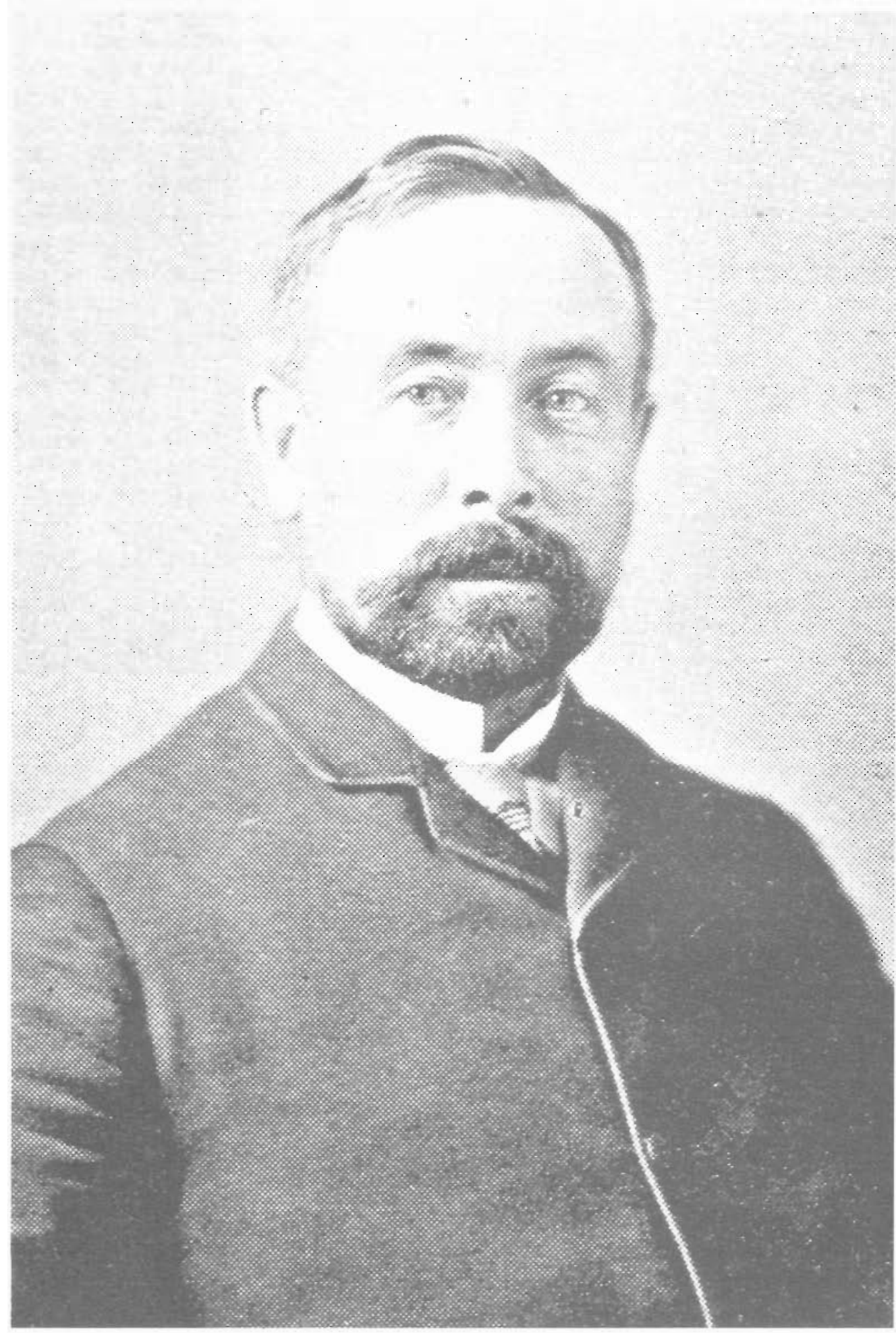

Duncan McNab McEachran 
charnpagne according to the taste of the occupants; about half a dozen women acted as waicers and their dress, manners and loose conduct and conversation indicated the life of immorality which they led. The scenery and surroundings were of the most prinitive nature, and the singing and acting were execrable. While we were looking on a large woman with a voice like a cow-horn attempted to sing a vilgar ditty, "Champagne and oysters."

The orchestra consisted of four pieces, lead by a cornet player who, as one of our party remarked, must have been eating onions, so disagreesble was the toot-teot of his brassy instrument.

Clearly, McEachran was not without a sense of humour.

Some of our party pleased the braves [of an Indian reservation] by giving them tobacco and the fair maidens by candies, of which they seem very fond. One of our party, more gallant than the rest, became fascinated by the pleasant smile, the white teeth and pretty face of a dusky maiden, jokingly expressed a wish to have her for his own, a wish which, unexpectedly to him, was communicated by an interpreter to her mother and brother, who agreed to make her his for the consideration of four ponies, which would cost about $\$ 60$ to $\$ 80$. This little bit of romance furnished us with no little amusement. However, our jocular friend, thinking discretion the better part of valour, and not knowing exactly how his first wife would approve the addition to the family circle, added another proof to the adage that men are deceivers ever. It was evident that, whatever the feelings of the maic may have been, her brother was not a little disappointed in being done out of his ponies.

Above all, McEachran was seriously concerned about the dangers of importing diseased cattle, a theme that runs through his whole professional life. He encouraged efforts to prevent the introduction of foot and mouth disease, pleuro-pneumonia and other infectious ailments from European countries. He repeatedly went to England demanding changes in their manner of treating stock. His ideas were sometimes ridiculed but, in 1875 , he persuaded the Canadian Government of the need to establish a quarantine system. In April 1876, he was appointed Chief Veterinary Inspector of Canada, a post he held until
1902, in which year he became Honorary Veterinarian to the Government of Canada. As first inspector of stock, he organised the first Cannadian catthe quarantine at Point Levis, Quebec. A few years later, the United States quarantine stations were remodelled on the ideas set out by McEachran. After 1902 he was appointed an Honorary Consultant Vetexinarian to the Canadian Government. Rose (1888) recorded:

The efficiency of the quarantine for cattle under his management has been thoroughly tested on two occasions vis. 1885, when the contagious disease, "foot and mouth" or vesicular epizootic, was twice brought into quarantine from Great Britain, so thorough was the quarantine that not only did it not extend beyond, but it did not even affect any other cattle, of which there were several hundreds within the enclosure. The prompt and effective manner in which pletro-pneumonia was dealt with in 1886 , when that fell destroyer was imported in a herd of Galloway, proved beyond coubt the efficiency of the quarantine and the ability of the inspectors to deal with contagious diseases.

In January 1879 he was commissioned to investigate pleuro-pneumonia (lung plague) that was prevalent in the United States, visiting New York, Long Island, New Jersey, Pennsylvania, Maryland, Yirginia and the District of Columbia. His work led to important steps being taken by the British and Canadian governments to prevent the import of diseased animals. He was also instrumental in establishing a Health of Animals Bureau in Ottawa and wrote the Contagicus Diseases Animal Act.

McEachran was greatly concerned for both animal and human well-being. He frequently consulted with medical practitioners on pathological matters. He was especially interested in many aspects of Montreal's sanitary conditions. He recognisea that milk could communicate infections and diseases, but it was 15 years before his recommendations were taken seriously. These were that all milk offered for sale should be regularly inspected as should all dairy establishments. A more disturbing tale is given by Osler and Clement (1883). The influence of McEachran's thinking on Osler can be seen in the following extract:

In the interests of public health, it is a matter of great importance that the food supply of cities should undergo strict supervision, with 
a view of excluding possible sources of disease...Speaking of Nontreal, meat inspection consists in the examination of the carcasses of all animals exposed for sale or killed at the abattoir, and its superficial character is clearly shown by the results of this examination...

The Highland Shepherds are stated to eat without ill effects the flesh of animals which have died of anthrax. In the case of pork it is not so much the flesh of salted meat which has been known to produce sickness as when made into sausages and brawn (head cheese).... this is not surprising to anyone who has watched their manufacture... Odds and ends go for mince meal, and too often, bits of old meat which is just beginning to turn. The experience is only too common of tasting in a mouthful of sausage the disagreeable flavour of a morsel which is high.

McEachran, in an address to graduating students, summarised the concern:

It is the veterinary surgeon's duty to acquire such a knowledge of disease and its symptoms and those of animals that he can protect his fellow man from what may be hurtful.

sicEachran was never wanting of the novel, but effective, solution to a problem. There was an outbreak of influenza amongst the horses in New York that brought transport to a virtual standstill. $\mathrm{He}$ went to the Brooklyn Station, chose a number of horses and ordered frequent stops and a barrel of ale and gruel. The horses were to take a drink at every stop. In a few days the services were back to norr.ial.

Duncan McEachran's other academic achievements included publications in the American Veterinary Review (1870 onwards), fellowship of Mccill University (1890), Dean of the Faculty of Comparative Medicine and Veterinary Surgery (18901903), Doctor of Veterinary Surgery (McGill University, 1890), Professor of Veterinary and Medical Surgery (1890-1903), Emeritus Professor of the Faculty of Comparative Medicine and Veterinary Surgery (1905-1924) and Doctor of Laws (McGill University, 1909). When McGill celebrated its centenary in 1922, graduates gathered to honour the founder of the Veterinary College and an impressive tribute was paid to him by Dr. Veranus A. Moore, Dean of New York State Veterinary College at Cornell.
Duncan was married on June 9, 1868 to Esther, third daughter of Timothy Plaskett of St. Croix, West Indies when he resided in Montreal. This family connection perhaps explains the apparent wealth accrued by McEachran early in his academic career. Duncan and Esther had two children, Evelyn Victoria, born on May 24, 1869 and Jeanie Blackney, born on September 19, 1871. Evelyn Victoria died in May 1874.

Duncan died at Ormstown, Quebec on October $13,1924$.

\section{Notes and Bibliography}

Bede, Cuthbert 1902 Argyll's highlands or MacCailein Mor and the Lords of Lorne. Edited by Johis Mackay. John Mackay, Glasgow.

Cameron, Thomas W.M. 1938 Veterinary education in Canada. The Veterinary Journal, volume 93 , 102-106.

Frost, Stanley Brice 1980 McGill University. For the advancement of learning. Volume 1 1801-1895, McGill-Queens University Press, Montreal.

Huntingdon Gleaner, The 1938 Dr. Duncan McEachran, promoter of the Ormstown Exhibition was Canada's greatest veterinary and health of animals promoter. The Huntingdon Gleaner 21 September 1938.

McEachran, Duncan McNab and Smith, Andrew 1867 The Canadian Horse and his Diseases. James Campbell, Toronto.

McEachran, Duncan McNab 1877a Veterinary education. American Veterinary Review, volume 1, $12-17,45-50,85-92,113-115$.

McEachran, Duncan McNab 1877b Russian government regulations with respect to the examination of veterinarians. American Veterinary Review, volume $1,115-117$.

McEachran, Duncan McNab 1877c Bone-spavin. A few practical remarks on this very common disease. American Veterinary Revicw, volume 1, 231234.

Mc $\$$ achran, Duncan McNab 1877d Veterinary ed- 
ucation [Correspondence]. American Veterinary Review, volume 1, 341-342.

McEachran, Duncan McNab 1878a The progress of the veterinary profession [Correspondence]. American Veterinary Review, volume 1, 388-390.

McEachran, Duncan McNab 1878b Veterinary jurisprudence. American Veterinary Review, volume $1,433-437$.

McEachran, Duncan. McNab 1881 Notes of a trip to the Bow River. North-west Territories. Reprinted from the Gazette, Montreal.

McEachran, Duncan. McNab 1920 Osler and the Montreal Veterinary College. Canadian Medical Association Journal, volume 10 (Osler Memorial Number), 35 .

McGill University Archives File number 3-35.

McGill University Calendars and Annual Reports 1889, 1902.

Mitchell, Charles A. 1938 A note on the early history of veterinary science in Canada. Canadian Journal of Comparative Medicine, volume 2, number 4. April 1938, pages 91--95.

Mitchell, Charles A. 1938 Montreal Veterinary College and Faculty of Comparative Medicine and Veterinary Surgery, McGill University. Canadian Journal of Comparative Medicine, volume 2, number 6, June 1938, pages 163-166.

Mitchell, Charles A. 1938 A note on the early history of veterinary science in Canada. French speaking schools. The French section of Montreal Veterinary College. Canadian Journal of Comparative Medicine, volume 2, number 10, October 1938, pages 295-296.

Mithcell, Charles A. 1938 A note on the early history of veterinary science in Canada. Canadian Jounnal of Comparative Medicine, volume 2, number 12, December 1938, pages 322-324.

Mitchell, Charles A. 1939 A note on the early history of veterinary science in Canada. Canadian Journal of Comparative Medicine, volume 3, number 10, October 1939, pages 276-281.

Morgan, H.J. 1898 The Canadian men and women of our time. Toronto.

Murphy, David A. 1960 Osler, now a veterinarian. The Canadian Medical Association Journal, volume $83,32-35$.

Osler, W. and Clement, A.W. 1883 Canadion Medical and Surgical Journal, volume 11, 325.

Rose, G.M. 1888 A. cyclopedia of Canadian biography. Toronto.

Teigen, P.M. 1984 William Osler and comparative medicine. Canadian Veterinary Journab, volume 25, $400-405$.

[T.W.M.] c1887 The Montreal Veterinary College and its founder and principal Art. VII.

Wallace, W. Steward 1963 McMillian dictionary of Canadian biography. Third edition, McMillan.s, Toronto.

Williamson, Hazel 1969 Doctor Duncan McEachran, F.R.C.V.S., V.S., (Edinburgh). McGill University Archives Acc. no. 923 (1). 



\title{
Notes and Comments
}

\section{From Chancellor Day to Today: McGill and the 130 Years of the Québec Civil Code}

\author{
By Robert F. Clarke \\ Law Librarian
}

In 1996 the McGill Law Library celebrated the 130th anniversary of the enactment of the first Québec Civil Code. The Faculty of Law has a long and honourable tradition of involvement with the development and revision of this unique Code. An exhibition of works from the collections of the McGill Law Library was held in Chancellor Day Hall from September 20 to November 3, 1996. The documents in this exhibition illustrated the provenance of the development of the Code. The article below was written in connection with the exhibition.

\section{A Civil Versus Common Law Tradition}

The modern Québec Civil Code traces its origins to the Coutume de Paris. The civil law tradition, exemplified by the Code Napoléon and perfected in the French Code civil (1804), proscribes and codifies the relationship in law between persons and property. The Civil Code is enacted as a statute, whereas the Common Law tradition, practised in all provinces of Canada except Québec, relies on the interpretation of prior judicial decisions, or precedent, to determine legal boundaries. The Common Law is not a code and thus is not defined by statute.

The unique quality of the duality of the Canadian legal system has gained the admiration of many over the years. Sir Wilfrid Laurier, a McGill law graduate who would go on to become Prime Minister of Canada and one of the nation's greatest statesmen, expressed his view to the McGill University convocation in 1864:

Two different legislations govern this country: French legislation and English legislation. Each of these legislations are not confined to the race to which they are intended but rather each rules simultaneously the two races, and, a fact worthy of note, this introduction in the same country of two systems of legislation entirely different has been done without violence or usurpation but simply by means of law and justice.

(From: Young, Brian. The Politics of Codification: the Lower Canadian Civil Code of 1866 . Montreal: McGill-Queen's University Press, 1994. p. 112)

\section{Charles Dewey Day: Principal, Chancellor and Codifier}

By the mid-19th century, it had become apparent that the application of seigneuriai law was no longer viable in a society which was becoming increasingly industrialized and complex. In the French-speaking legal community of Québec, a succession of legal theorists underlined the need for a uniquely Canadian civil code, to be enshrined in law and which would assure the distinctiveness of the French-Canadian legal 
tradition. From the English-speaking legal community came a growing unrest with a legal tradition that was neither written in English nor representative of the main facets of British Common Law.

During the same period, a number of legislative developments occurred which further underlined the inadequacies of the existing civil law regime. Consequently, the legislature of Lower Canada passed an act in 1857 which established a Codification Commission charged with the writing of a civil code for the province. This Commission began to meet in 1859. Among the five Commissioners was Charles Dewey Day, a judge and future Chancellor of McGill University.

Born in Vermont in 1806, Charles Dewey Day came to Lower Canada during the War of 1812 and was admitted to the Bar of Lower Canada in 1827. The Faculty of Law was established in 1853 while Day was Acting Principal of MeGill, an appointment he held until 1855. Day's influence in the drafting of the first Civil Code was considerable. Although it is not clear whether his roots in Montreal's anglophone community and his influence on the bench in commercial matters were factors, Day undertook the reponsibility for authoring most of the Code's chapters on the law of Obligations (contracts) and commercial transactions. Day's strong personality, and his drafting of Obligations, gave a central role in the Code to contracts and to Day's interpretations and definitions. Articles of Obligations subsequently influenced titles of the Code drafted by other codifiers.

In 1864 - two years before the enactment of the Civil Code - Charles Day was named Chancellor of McGill University, a post he held until 1883. Much of Day's success in drafting the major portions of the code has been attributed to his interactions with McGill colleagues during the Commission period.

The Code, officially titled the Civil Code of Lower Canada (C.C.L.C.), was ultimately brought into being by an act of the Legislature of the Province of Canada in 1865 and came into effect in 1866. The C.C.L.C. had originally been intended by some as a timeless document that would rarely need to be changed, although a number of important and regular amendments were made to it throughout its 125 year history.

\section{McGill and the Revision of the Civil Code}

It was not until 1955 that the Québec legislature decided to systematically revise the Code with a view to putting it more in step with the social, political and economic realities affecting private law relations in Québec. The Civil Code Revision Office (CCRO) was created in that year, with the Honourable Thibaudeau Rinfret, former Chief Justice of the Supreme Court of Canada, as its first Chairman. In 1966, Professor Paul-André Crépeau of McGill University's Faculty of Law was appointed Chairman. Several other McGill law professors - John E.C. Brierley, Madeleine Cantin Cumyn, Yves Caron and Ethel Groffier, to name only a few - were prominent participants in the activities of the CCRO during the period of its operation. The task before the CCRO was an enormous one: to update the 1866 Code and to articulate the basis for reform and revision that a new code might touch upon. Under the direction of Crépeau, the Civil Code Revision Office created some 40 committees, each charged with examining a particular portion of Québec's private law with a view to its reform. By 1977 the CCRO's work was completed in draft. The Report on the Québec Civil Code (1977-78) represents the principal manifestation of the work of the CCRO.

\section{1: A Completely New Civil Code for Québec}

In spite of the work of Brierley, Crépeau and their colleagues, the Québec government was slow to move on the recommendations of the CCRO as set out in its final report. During the 1980s, some additional changes were brought to the C.C.L.C., for example in the area of family law. The Québec National Assembly passed a series of laws which updated the Civil Code but did not completely revise it as proposed by the CCRO. 
Finally, commencing in 1987, the Québec National Assembly passed a series of implementation laws to bring into effect a new civil code, to be called the Civil Code of Québec (C.C.Q.). A 1997 Act of the National Assembly set the final stage for the implementation of the new Code.

Most of the provisions of the new Code had come into force by January 1, 1994. The 3,168 articles of the C.C.Q. bear some resemblance to the original Civil Code of Lower Canada but incorporate a significantly different interpretation of private law.

Further information about McGill University and its involvement with the development of the Civil Code of Québec may be obtained by contacting the Law Library at (514) 398-4715, extension 1556.

Information about the Archives of the Civil Code Revision Office may be obtained via the World Wide Web at URL: http://www.library.mcgill.ca/ccro/

\title{
A Frank Scott letter from 1937
}

\author{
By A.J. Hobbins \\ Associate Director, Administration, Libraries
}

John Peters Humphrey (1905-1995), author of the first draft of the Universal Declaration of Human Rights, and F.R. Scott (1899-1985), famed constitutional lawyer and poet, became friends when they met as undergraduates at McGill University in. 1926, and they later spent many years together as colleagues in the McGill Faculty of Law. Humphrey, two years behind Scott in law school and six years younger, was very much influenced by Scott's ideas. Humphrey returned to Montreal in 1930 after studying in France for a year, He observed the misery of the Great Depression first hand and immediately recognized the need for a social safety net. He became a socialist and a member of the League for Social Reconstruction, an organization co-founded by Scott. Humphrey practiced law in Montreal for a few years before McGill's Dean of Law, Percy Corbett (1892-1983), invited him to join the Faculty to teach Corbett's course in Roman law and eventually that in international law. At this time the only other full-time members of the faculty were Scott and (Charles) Stuart Le Mesurier (b. 1888). Humphrey accepted the position, which was held for a year whilst he studied Roman law in Paris on a fellowship from the Carnegie Endowment for World Peace.

The year 1936/37 was a dramatic one on the European stage. In Hitler's Germany the Olympic Games became a propaganda event, while thousands of German citizens - principally alleged communists, Jews and homosexuals - were being placed in concentration camps. Mussolini's Italy was gearing up for the conquest of its African empire. In Spain the civil war, a clash in extreme ideologies, was beginning in earnest. In the Soviet Union Stalin had already begun his great purges, while from abroad the exiled. Trotsky vilified him. Humphrey visited Germany and Italy, and observed developments elsewhere with interest. He reported many of his observations in letters to his sister Ruth, and to his colleagues at McGill. One of Frank Scott's replies $^{1}$ is given below, followed by some contextual explanation for each paragraph. 


\author{
Faculty of Law \\ McGill University \\ Montreal
}

February 14th 1937

Dear John,

I have to thank you and Jeanne for your letter about your Italian experiences, and also for the very interesting book by Gide which Marian and I have enjoyed discussing - if enjoyment is the word to use about a rather discouraging situation. I felt very much as Gide did when I was in Russia, only then the element of repression seemed to be getting better all the time instead of worse. Now every socialist will have to explain away more failures within his own ranks. At least we can learn from this Stalin-Trotsky fight that the principle of dictatorship can corrupt even the best-intentioned people.

I have seen letters of yours to Corbett and LeMesurier [sic], and am glad to know you are having an interesting time. I think you are right to take the extra year necessary for your degree, if you can manage it. It is a small time in relation to your future academic career, for which the degree and the work in Paris will be invaluable.

Nothing of special note is happening here. The job of surveying and reorganizing the work of the university is going steadily under Morgan, who in this respect is first rate. LeMesurier [sic] will make a good Dean if he keeps well; he has lots of ideas. We are pursuing the idea of a school of government.

In the country at large, the development is slow. the CCF members are putting up a good fight in Ottawa. They are as usual the only opposition. The new defence estimates give them an opportunity, but dear old J.S.W. is no rabble-rouser.

The recent Privy Council decisions are disastrous. They have split the country into provincial sovereignties even in the international field. The Quebec secessionists have had half their demands handed to them. This, and Spain, and Stalin, make blind faith necessary.

My best to Jeanne,

Frank Scott.

\title{
Explanation
}

\section{Paragraph $\mathfrak{l}$.}

Humphrey's wife was Jeanne Godreau (1903-1980), while Scott was married to artist Marian Dale (19061993). Scott had visited the Soviet Union in 1935 and, while disturbed by the repressive nature of dictatorship, believed somewhat wishfully that the situation was improving. ${ }^{2}$ Humphrey sent him a copy of André Gide's 1936 book, Retour de l'U.R.S.S. Gide had supported communism financially and ideologically since the beginning of the Great Depression, and was invited as an honoured guest to Maxim Gorki's funeral. Returning, he wrote a bitter critique of Stalin's policies and practices in which he renounced communism. Up to that point in time western socialists had held up the Soviet Union as a model of progress, although 
this position became more and more difficult to sustain as awareness of Stalin's excesses grew. Trotsky, who had been relatively silent since his exile in 1928, suddenly became more active at this juncture, establishing the Fourth International as a rival to the Moscow-based Komintern and becoming more vociferous in his criticisms of Stalin.

Paragraph 2.

Humphrey discovered in France that if he stayed at the university for a few months more and wrote a short dissertation, he could be awarded a doctorate. He wrote to Corbett and Le Mesurier, who became Dean in 1936, inquiring as to whether they would extend his leave to allow him to pursue the doctorate. Scott was evidently enthusiastic about the notion of graduate degrees for teaching academics, but his colleagues were less sanguine. On January 8, 1937 Le Mesurier wrote to Humphrey that, while he could extend the leave, there would be no financial assistance from McGill (Humphrey had suggested he be allowed to make up the missed work later). In terms of the value of the doctorate he added the following observation:

I realise of course the value of the degree to you in the event of your applying for a position in another university. We ourselves attach very little importance to it. This may be sour grapes but there it is.

When this drew a sharp response from Humphrey, he clarified matters on April 2 by saying:

When I said in one of my previous letters that we did not attach much importance to a doctor's degree I was simply referring to the tag and not the work which you are now doing.

\section{Paragraph 3.}

It may at first seem surprising that Scott, the radical young professor, would approve of the work done by Principal A.E. Morgan (1886-1972), the representative of the administration, but there were good reasons for the approval. McGill was in financial trouble during the Depression and survived in part through the sale of assets and the generosity of the Board of Governors, who voluntarily taxed themselves. Given this generosity Board members felt that members of faculty should present the capitalist view of society as vigorously as the socialist side seemed to be presented. In particular they wanted Morgan, who had been hired in June 1935, to do something about the outspoken Frank Scott. However, when the Chancellor Sir Edward Beatty (1877-1943) alerted Morgan to the socialist content of one of Scott's publications, the Principal responded:

I am glad you write to me, although I have no solution to offer for a problem which I hope will always be with us. I hope, because as I see it the only condition of its solution is the establishment of a totalitarian state, which God forbid!

In 1936, after McGill had undergone several years of retrenchment, Morgan had established a joint Staff/Board of Governors committee called the Consultative Committee on University Development. The ccmmittee's mandate was to examine the entire university in terms of current needs and estimate the cost of meeting these needs. Morgan was frequently at loggerheads with the Board of Governors on a variety of issues. He tendered his resignation as Principal on April 17, 1937 after less than two years in office. ${ }^{3}$ Le Mesurier served as Dean until 1946, although nothing appears to have come of his ideas for a school of government.

\section{Paragraph 4.}

The Cooperative Commonwealth Federation (CCF) was the original name for the New Democratic Party. James Shaver Woodsworth (1874-1942) became its first leader in 1932. The party elected several Members of Parliament in the 1935 federal general election, although the official opposition was the Conservative Party. Woodsworth was a respected Methodist minister and pacifist but not, apparently, a great orator. 
The 1937 budget predicted a deficit of $\$ 35,000,000$ while recommending that more than that amount be spent on armaments. This caused the socialist rallying cry of "Disarmament with a surplus".

\title{
Paragraph 5.
}

In 1935 Conservative Prime Minister Richard Bennett's government enacted "New Deal" legislation aimed at easing the effects of the Depression. This legislation included the Employment and Social Insurance Act, the Natural Products Marketing Act and the Minimum Wage Act. The nine provinces protested that these Acts were an infringement on provincial jurisdiction as defined by the British North America Act. In January 1937 the Judicial Committee of the Privy Council in London found in the provinces' favour, ruling almost all the legislation ultra vires.

\section{Notes}

1. The letter is currently in the possession of A.J. Hobbins, Humphrey's literary executor, but will eventually be donated to the McGill University Archives.

2. See F.R. Scott "Impressions of a visit to the USSR" Canadian Forum vol. 15 (December, 1935) pp. 382385. In this Scott stated "...the present dictatorship..involves tactics that positively hinder the attainment of socialism. Despite these qualifications I came away believing that the objectives of the revolution will eventually be achieved."

3. For a fuller description of the question of Scott, Morgan and the Board of Governors, see Stanley B. Frost, McGill University for the Advancement of Learning, Vol. 2 (Montreal: McGill-Queen's University Press, 1984) pp. 193-197.

\section{McGill Law Library Moves into Cyberspace(s)}

\author{
By Kate Williams \\ Director, University Relations Office
}

\begin{abstract}
"To leave no stone unturned" is the felecitous phrase from Euripedes engraved on the stone exterior of the new McGill law library, which was inaugurated on September 17, 1998 in the presence of Quebec's LieutenantGovernor Lise Thibault and hundreds of guests. "Given the years of effort to raise funds for the building, it is an apt reminder of what the University must do to sustain its margin of excellence and international reputation," says McGill Principal Bernard Shapiro. Hampered for decades by totally inadequate space while the student body increased by $50 \%$ and legal scholarship exploded, the old law library was considered one of the worst in Canada. Now, thanks to more than 300 donors, the new library welcomes users into a startingly different environment, one designed to bridge the past and the future in radical, sometimes light-hearted, sometimes sobering ways. The architect is Dan Hanganu, considered one of Quebec's hottest architects.
\end{abstract}

Named for major benefactor and graduate Nahum Gelber (B.A. '54, BCL ' 57 ), the $\$ 11.5$ million structure was made possible by large and small contributions from individual graduates, law firms, foundations and friends of the Faculty. "We're thrilled that so many people supported us," says Dean Stephen Toope. 
With a multipurpose atrium linking it to Old Chancellor Day Hall on Peel Street, the Nahum Gelber Law Library is described in a commemorative brochure as a "suitable consort [for surrounding mansions], with its dark seriousness, dignity and occasional touches of whimsy." Hanganu himself has said it is "a box - a simple box" conceived to reveal inward beality and gravity of purpose "for people who come to read and learn - and grow."

According to Toope, the Library is, however, much more than a box - it is a catalyst for the Faculty which, poised to mark its $150^{\text {th }}$ anniversary throughout the 1998-99 academic year, is plunging into cyberspace with remarkable enthusiasm. Every one of its 350 work stations, for example, is wired for laptops and connected to the Internet, with user-friendiy technology support "instantly visible as you walk in," he notes. Toope and Law Librarian Robert Clarke point out that students have been deeply involved in the project, influencing the Library's design to an exceptional degree and helping to ensure that it is the first completely barrier-free library in the entire University.

Implementing the Gaculty's new curriculum will continue the momentum forward during 1998-99 and beyond. "Our recent revisions are dramatic, but they're based or wide consultation and, in my view, show tremendous courage and creativity. Students will have more choice, and the two great legal systems of the Western world, common law and civil law, will truly illuminate one another, almost in a dialogue, right from the first year of study," says the Dean.

\title{
Walter Hitschfeld Geographic Information Centre
}

\author{
By Carol Marley \\ Information Services Librarian
}

November 14, 1997 saw the official opening of the new Walter Hitschfeld Geographic Information Centre (GIC). Occupying the entire fifth floor of Burnside Hall, the GIC combines the former Walter Hitschfeld Environmental Earth Sciences Library with the new GIC Computer Lab devoted primarily to geographic information systems (GIS) activities. The library, without walls, serves as a repository of digital geographic data (in addition to traditional maps and atlases, as well as collections in the disciplines of cartography and GIS). The lab provides the means of analyzing and mapping these data with GIS software and state-of-the art computer facilities. The new GIC cost over $\$ 280,000$, with generous contributions from the Dean of Science, Alan Shaver, and the Director of Libraries, Frances Groen.

This exciting new partnership between the Faculty of Science and the McGill University Libraries has enabled the University to bring together a team of GIS "experts" whose mission is to further the cause of GIS literacy at McGill. There are approximately 60 computers, many of these being Pentium 200 MMXs with 17 inch monitors attached to a new file server and Lexmark colour laser printer. Digitizing and scanning equipment is also available. There is an interactive classroom for teaching GIS, data retrieval and Web navigation. The instructor's computer is permanently connected to a SONY computer projection system. GIS software includes ESRI's Arcview 3.1, and accompanying Network Analyst and Spatial Analyst modules, Map Info 4.1 and Idrisi 4 for Windows.

The GIC is open seven days a week in term time. Graduate students in the Department of Mathematics, Geography and Atmospheric and Oceanic Sciences, as well as selected undergraduates, have the additional advantage of 24 hour access using a swipe card and PIN system.

The library's Web page gives details on collections and services, 
http://www.geog.mcgill.ca/heeslib/welcome.html

The Hitschfeld Hotlist, contained therein, evaluates, organizes and provides access to authoritative Web sites in the fields of cartography, geographic information systems, remote sensing, geography, environmental studies, global change and pertinent "virtual" reference sources.

Naming the library in honour of Waiter Hitschfeld is eminently fitting. Dr. Hitschfeld not only set the tone and the standard for research within McGill as Dean of Graduate Studies and Vice-Principal Research, but also became a respected advocate on the national scene for the importance of science education and research. The name serves as a reminder of the connection between Walter Hitschfeld and McGill University. 


\section{Chronicle}

\section{Blackader-Lauterman Library of Architecture and Art}

\section{Notable Acquisitions by Purchase}

Early Printed Books, 1478-1840: Catalogue of the British Architectural Library Early imprints Collection. Compiled by Nicholas Savage et al, London: Bowker-Saur, 1994-.

Jagger, Janette. Designers International Index. London: Bowker-Saur, 1991. A 3 volume set.

Spanish Artists from the Fourth to the Twentieth Century: a Critical Dictionary. New York: G.K. Hall, $1993-1996$.

Encyclopedia of Vernacular Architecture of the World. 3 volumes. Cambridge: Cambridge University Press, 1997.

The Renaissance from Brunelleschi to Michelangelo: the Representation of Architecture. Edited by Henry A. Millon and Vittorio Magnago Lampugnani. Trade Edition. New York: Rizzoli; Milan: RCS Libri \& Grandi Opere, 1997.

Skaug, Erling S. Punch Marks from Giotto to Fra Angelico: Attribution, Chronology, and Workshop Relationships in Tuscan Panel Painting: With Particular Consideration to Florence, c. 1330-1430. Oslo: IIC, Nordic Group, the Norwegian Section, 1994

World Trademarks, 100 Years: an International Collection of Symbol and Logotype Designs of the Last One Hundred Years. Edited by Rick Eiber. New York: Graphis U.S., Inc., 1996.

Avery's Choice: Five Centuries of Great Architectural Books: One Hundred Years of an Architectural Library. 1890-1990. Adolf K. Placzek, general editor. New York: G.K. Hall, 1997.

Rittich, Werner. Architektur und 3auplastik der Gegenwart. $2^{\text {nd }}$ edition. Berlin: Rembrandt-Verlag, 1938.

Pevsner, Nikolaus. A Compendium of Pevsner's Buildings of England on Compact Disc Compiled by Michael Good. (CD-ROM) Oxford: Oxford University Press, 1995. Provides an electronic index to the information contained in 42 volumes of the series.

\section{Catalogue Raisonnés}

Magne, Emile. Nicolas Poussin, premier peintre du roi, 1594-1665: (documents inedits) suivi d'un catalogue raisonné... Brussels \& Paris: G. van Oest \& cie, 1914.

Daulte, François. Alfred Sisley: catalogue raisonné de l'oeuvre peint... Lausanne: Durand-Riuel, 1959. No. 24 of a limited edition of 150 with the author's signed presentation copy to "Monsieur et à Madame Leigh Block".

Breeskin, Adelyn Dohme. Mary Cassatt: a Catalogue Raisonné of the Oils, Pastels, Watercolors, and Drawings. Washington: Smithsonian Institution Press, 1970. 
The Poussin, Sisley and Cassatt catclogue raisornés will be part of the Rare Books Division, Art and Architecture Collection

Drawings from the Clark Art Institute; a Jataiogue Raisonné of the Robert Sterling Clark Collection of European and American Drawings... Ner Harer: Zale University Press, 1964.

Schwarz, Arturo. The Complete Works of Marcel Duchamp. New York: Harry N. Abrams, 1970. Author's presentation copy to Andre Menard.

Hassrick, Peter H. Frederic Remington: A Catalogue Raisonné of Paintings, Watercolors and Drawings. Cody, Wyoming: Buffalo Bill Historical Centre, 1996. A z-volume limited edition including a laser optical disc (CD-ROM).

Levin, Gail. Edward Hopper: A Catalog Raisonné. New York: Whitney Museum of American Art, 1995. A 4-volume definitive catalog with a CD-ROM.

Sanchez Canton, F.j. Goya and the Black Paintings. $1^{\text {st }}$ English language edition. London: Faber and Faber, 1964.

Plon, Eugene. Les Maitres italiens au service de la maison d'Autriche. Leone Leoni, sculpteur de CharlesQuint, et Pompeo Leoni, sculpteur de Philippe II. Paris: E. Plon, Nourrit et cie, 1887.

Hediard, Germain. Fantin-Latour: catalogue de l'oeuvre lithographique du maitre, precede d'une étude par Germain Hediard et d'une notice sur Germain Hediard par Leonce Benedite. Nouvelle édition. Paris: Libraire de l'art ancier et moderne, 1906.

Hauptman, William. Charles Gleyre, 1806-1874. Zurich: Swiss Institute for Art Research; Princeton, N.J.: Princeton University Press; Basle (Switzerland): Wiese Pub., 1996.

Cohn, Albert M. George Cruikshank, a Catalogue Raisonné of the Work Executed During the Years 18061877; with collations, notes, approximate values, facsimiles, and illustrations, by Albert $M$. Cohn... London: Office of "The Bookmar's Journal", 1924.

Bodelsen, Merete. Gaugin's Ceramics: a Study in the Development of His Art. London: Faber and Faber, In Association with Nordisk-Sprog-og Kulturforlag, Copenhagen, 1964.

\section{Other Acquisitions}

Dimier, Louis. Histoire de la peinture de portrait en France au XVIe siècle... Paris: G. van Oest, 1924-27.

Weitzmann, Kurt. The Miniatures of the Sacra Parallela, Parisinus Graecus 923. Princeton: Princeton University Press, 1979.

Sanchez Canton, F.J. Catalog de las Pinturas del Instituto de Valencia de Don Juan. Madrid: Talleres ti. "Edicorial Reus", 1923.

Delogu, Giuseppe. Il Ritratto nella Pittura Italiana. Bergamo: Istituto Italiano d'Arti Grafiche, 1975-1976.

Daulte, François. L'aube du XXe siècle; de Renoir à Chagall. Genève: Petit Palais, 1968.

Musée du Louvre. Inventaire general des dessins des écoles du nord: Écoles allemande et suisse. Paris: Musées nationaux, 1937-1938. 
Thiery, Yvonne. Le paysage flamand du XVII siècle. Paris \& New York: Elsevier, 1953.

Plon, Eugene. Benvenuto Cellini, orfevre, medailleur, sculpteur: recherches sur sa vie, sur son oeuvre et sur les pieces qui luie sont attribuées. Paris: E. Plon et cie, 1883.

Klimt, Gustav. Gustav Klimt: Erotic Drawings. London: Thames and Hudson, 1980.

Williams, John. The Illustrated Beatus: a Corpus of the Illustrations of the Commentary on the Apocalypse. London: Harvey Miller Publishers, 1994-..

Muller, Arthur. Les terres cuites votives du Thesmophorion: de l'atelier au sanctuaire. Athenes: École francaise d'Athenes; Paris: Depositaire, Diffusion de Boccard, 1996. Études thasiennes no. 17.

Packer, James E. The Form of Trajan in Rome: a Study of the Monuments. Berkeley, CA: University of California Press, 1997.

Bouiton, Alfredo. Camille Pissarro en Venezuela. Caracas: Editorial Arte, 1966.

Monk, Lorraine. Photographs that Changed the World: the Camera as Witness, the Photograph as Evidence. Toronto: Macfariane Walter \& Ross, 1989. Deluxe edition autographed by the author. Insert: One sepia toned archival photograph of Chief Sitting Bull photographed by William Notman

\section{Gifts of Note}

The Blackader-Lauterman Library received a collection of 240 books from the Mciord Museum Library, mostly on costume. Ms. Marcia Flanders donated a collection of auction catalogues on isatin America, Decorative, Impressionist and Modern Art. M. Jacques LeNormand donated a collection of books on Egyptian art and archaeology and on Egyptology.

\section{Blacker-Wood Library of Biology}

The Scripps Institution of Oceanography donated a copy of A.P. Vinogradov's The elementary chemical composition of marine organisms to the library. Dr. Yves Grenier donated 6 volumes of the 1785 edition of Georges Buffon's Histoire naturelle générale et particulière... Mrs. Pat Grant donated volumes 23-37 of Bat research news and the 1983-1997 volumes of Bats. Ms. Eleanor MacLean donated the 3 volume Dictionnaire du durwinisme et évolution.

Over the past two years, the following money donations have been received for the Kafer Boothroyd Endowment Fund, the interest from which is used to buy books: 
Chronicle

Mr. Frederick Anderson

(Last 3 Years' Gifts Matiched from Northern Telecom)

Dr. Roger Boothroyd.

Mrs. Shirley Cahr

Dr. John Carson

Mrs. Linda Cobbett

Mrs. Mary Finlay

Mr. Mark Hanchet

Dr. C.E. Hollingworth

Dr. E. Kafer
$\$ 585.00$

885.00

975.00

50.00

135.25

125.00

368.75

533.50

328.88

582.50
Mr. D. Lank $\quad 100.00$

Mrs. Dorothy MacLean $\quad 195.00$

Miss Eleanor MacLean $\quad 587.50$

Montreal Zoological Society $\quad 100.00$

Mr. Henry K. Schultz $\quad 300.00$

Mrs. Hugh Smart $\quad 25.00$

Twenty-First Century Fund $11,838.96$

Dr. Carl Wellstead 146.27

TOTAL \$ $17,861.61$

We also received $\$ 10,000$ from the McGill Biology Students Union (MBSU), most of which was used to buy serial backfiles, such as Biodiversity and conservation, and Genes to cells, although $\$ 1,990.00$ of the 1997/98 donation is being used to buy a networkable laser printer to use with our 3 PERUSE workstations and 1 Midas workstation, as well as the 5 computer workstations donated to Blacker-Wood by the Science Undergraduate Students (SUS).

\section{Division of Rare Books \& Special Collections}

\section{Donations}

Joe King donated a collection of 10 prints by mainly British artists primarily from the first half of the twentieth century. Works by Stanley Anderson, Muirhead Bone, David Cameron Young, Henry Rushbury, Alphonse Legros and Caroline Armington.

The family of the late Saul Shapiro donated his collection of over 5,000 English-language titles relating to Jewish settlement in Canada, Jewish history, art, literature and the Holocaust.

May Cutler donated the archives of her Montreal publishing house Tundra Books/Les livres Tundra. Covering the period 1967-1997, the donation includes 2.5 linear metres of correspondence with Tundra artists and authors including William Kurelek, and a complete set of the some 250 titles published by 'Tundra and 52 foreign language editions.

The Canadian Olympic Association transferred their Olympics documents collection to the Division in 1997. The more than 60 metres of material includes official publications from every modern Olympic Games beginning with Athens in 1896. There is also material relating to the Commonwealth Games.

Irena Murray donated a colour lithograph by the Russian artist Vladimir Lebedev produce in 1923 for the Russian Telegraph Agency ROSTA. Also a copy of Claude Laclanche-Boulé, Typographies et Photomontages Cronstructivistes en U.R.S.S. (1984).

Sheila Bourke donated 10 children's books including one by the Canadian illustrator Palmer Cox.

Martin Cohen donated 20 Insel-Bucherei titles to be added to that collection.

Mary J. Norton donated 77 volumes of the series Britain in Picture (1941-1948). 


\section{Acquisitions}

18 books designed and illustrated by John Heartfield and published by Malik-Verlag in Berlin between $1922-1932$.

Junius Collection: 120 volumes of editions of the Letters of Junius and discussions of the authorship of the letters. The collection includes many eighteenth century editions. Junius was an anonymous eighteenthcentury English political writer whose work is of interest not only for its political content but also because it is "possibly the most effective use of slanderous polemic ever employed in English political controversy".

Eleven volumes published by the Circle Press, London, 1983-1996.

incunabula

Gaius Caecilius Plinius Secundus, Epistolae. Milan: Philippus de Lavagnia 1478.

\section{Canadiana}

British American Land Company: Views in Lower Canada. London: Day \& Haghe, 1836.

Letters from Canada. Quebec: Morning Chronicle Office, 1862.

Traité sur la tenue générale d'une terre dans le Bas-Canada. Toronto: Elgin \& Kincardine, 1851.

Ada Florence Kinton, Just One Blue Bonnet: the Life Story of Ada Florence Kinton, Artists and Salvationist. Toronto: W. Briggs, 1907.

Calvin L. Hatheway, The History of New Brunswick, from its First Settlement, containing a Geographical Description of the Province... Fredericton: James P.A. Philips, 1846.

Liaison: revue d'littérature et d'art. [Periodical]. Montreal, 1946-1950.

James McCarroll. Ridgeway: An Historical Romance of the Fenian Invasion of Canada. 1st edition. Buffalo: McCarroll, 1868.

John O'Neill, Information for Intending Emigrants to Canada. Liverpool: David Marples, 1878.

Edward Roper, By Track \& Trail: A Journey through Canada. London: W.H. Allen \& Co., 1891.

Alexander Somerville, Narrative of the Fenian Invasion of Canada... with a Map of the Field of Combat at Limestone Ridge. Hamilton, Ont.: 1866.

Winifred A. Stearns, Labrador: A Sketch of Its People, its Industries and Its Natural History. Boston: Lee and Shepard, 1884.

\section{Canadian Literature}

Irving Layton, Now is the Place (with original forward). Montreal: First Statement Press, 1948.

George Stewart, Evening in the Library. St. John, N.B.: R.A.H. Morrow, 1878 


\section{Chronicle}

Ellen Thorneycroft Fowler, A Double Thread. Montreal: Montreal News Company, 1899.

Napoléon Aubin, ed., Les veillées du Père Bronsens. Beloeil, QC: 1865-1866.

Theodore Koenig, Clefs neuves: poèmes ouverts, poèmes fermés. Montreal: Editions Erta, 1950.

\section{Colgate Collection}

Notes on the Elston Press of Clarke Conwell \& Hellen Marguerite O'Kane, 1900-1905. Wilmington: Douglas M. Harris, 199 ?.

Rose Adler, Reliures. Paris: Moreau, ca. 1925.

Rufinus: the Complete Poems in English Versions oy Robin Skelton. Mission, B.C.: Barbarian Press, 1997. Endgrain: Contemporary Wood Engraving in North America. Mission, B.C.: Barbarian Press, 1994.

Sandra McPherson, Beauty is Use. Neward, VT: Janus Press, 1997.

Judith Haswell, From Finland. Newark, VT: Janus Press, 1997.

Dante Alighieri, La Vita Nouva di Dante Aligieri Fiorentino. Chelsea: Ashendene Press, 1932.

Ecclesiasticus. The wisdom of Jesus the Son of Sirach. commoniy called Ecclesiasticus. Chelsea [London]: Ashendene Press, 1932.

Longus, Les amours pastorales de Daphnis et Chloe / traduction de Messire Amyot. Chelsea [London]: Ashendene Press, 1933.

Claude Haeffely, Le Sommeil de la neige. Montreal: Editions Erta, 1956.

Margaret Kaufmann, Praise basted in: a friendship quilt for Aunt Sallie. West Burke, VT: Janus Press, 1995.

Denise Levertov, Batterers. West Burke, VT: Janus Press, 1996.

Pablo Neruda, Oda a la Typografia. Santiago de Chile: Nascimento, 1956.

\section{English Litcrature}

Oliver Goldsmith, ed., The Beauties of English Poesy... London: For William Griffin, 1767.

Percy Bysshe Shelley, Queen Mab. London: W. Clarke, 1821.

Percy Bysshe Shelley, The Revolt of Islam. London: Printed for John Brooks, 1829.

Hannah More, Cheap repository tracts. London: Hazard \& Marshall, 1797-1797.

Hannah More, Cheap repository for moral and religious publications. [Prospectus/Advertisement]. [London]: Sold by J. Marshall, printer to the Cheap repository, ... and R. White, London; [Bath]: by S. Hazard, Bath..., [1796?]. 


\section{Chronicle}

\section{General Rare Book Collection}

Emile Zola, Une campagne 1880-1881. Paris: G. Charpentier, 1882

Richard Price, Four Dissertations: 1. On Providence. II. On Prayer. III. On reasons for expecting that virtuous Men shall meet after Beath and in a State of Happiness. IV. On the Importance of Christianity, the Nature of Historical Evidence, and Miracles. 2nd edition. London: Printed for A. Millar and T. Cadell, 1768.

Lothar Schreyer, Kreuzigung: Spielgang Werk VII. Hamburg: Werkstaat der Kampfbühne, 1920.

\section{Philosophy}

Jean-Jacques Rousseau. The works of 3.3 . Rousseau ironsiated from the French. Edinburgh: Printec. for J. Bell, J. Dickson \& C. Elliot, 1773-74.

Soren Kierkegaard. Fortegnelse over Dr. Sor n Kierkegaards efterladte Bogsamling som bortsaelges ved offentlig Auction Tirsdagen, den 8de April, 1856... Copenhagen; Hagerup Lynge, Schwartz, 1856.

\section{Manuscripts and Private Papers}

Cochon (Cauchon) Family of Château Richer, Quebec, Archive. [1660-1900?.

F. Nation. "Notes of a Trip Around the World Starting from Toronto on Saturday 8th October, 1892". 2 volumes.

H.J. Morgan. Another accession of correspondence and other material for this Canadian bibliographer and his family.

Napoleonic Wars in Egypt, 1801. "General Order Book, HQ, Camp Before Alexandria". This order book details the activities of the British army in the aftermath of the defeat of the French in Egypt.

Napoleon I, Emperor of the French, et al, 1769-1821. Collection of 42 letters by prominent diplomats involved in the ending of the Napoleonic Era. [1807-1816].

\section{Map Collection}

Plan of the City of Westmount, Parish of Montreal. Westmount, 1911.

Plan of a property known as "Queen's Park" belonging to H.A. Wilder E Co. and U.H. Dandurand, Village of Verdun, Parish of Montreal. Montreal: H.Q. Wilder \& Co., 1896.

Insurance plan of the city of Montreal. Vol. 8 Chas E. Goad Co., 1914. (one of 2 copies known in Canada).

Fire Insurance Plans of Factories and Mills. (25 isometric drawings.) Chas. E. Goad, 1880-1906.

James Lovell Wiseman, Three panoramic views of Montreal: I. West. II. Centre. III. East. Montren: J.L. Wiseman, 1904. 
Chronicle

\section{Humanities and Social Sciences Library}

\section{Selected Titles Purchased from Endowments and Gifts}

\section{Arts Undergraduate Society}

Civilizations of the Ancient Near East. New York: Scribner, 1995. $4 \mathrm{v}$.

Encyclopedia of World Terrorism. Armonk, N.Y.: Sharpe Reference, 1997.

Film Index International (computer file). 1932-1997.

Masterplotss II. Women's Literature. Pasadena, Calif.: Salem Press, 1995.

Film Index International (computer file). 19.32-1997.

Le Monde. (microfilm) 1944-1967.

The Motion Picture Guide Annual. Chicago: CineBooks, 1992-

Museum of Broadcast Communications Encyclopedia of Television. Chicago: Fitzroy Dearborn Publishers, 1997. $3 \mathrm{v}$.

Sunday Times. (microfilm) 1900-1952. London [England]: Allied Newspapers, 1931-

Vietnam, the Media, and Public Support for the War (microfilm) Frederich, Md. University Publications of America, Inc.y 1986.

\section{Birks (Religious Studies)}

Companion encyclopedia of theology edited Peter Byrne and Leslie Houlden. London: Routledge, 1995.

The Damascus document reconsidered edited by Magen Broshi. Israel Explorations Society, 1992.

Early Christianity in coniext: monuments and documents, edited by F. Manus and E. Alliata. Franciscan Printing Press, 1993.

Emery, Kent. Monastic, scholastic and mystical theologies from the later Middle Ages. Aldershot: Variorum, 1996.

Evans, Craig A. Jesus and his coniemporaries: comparative studies. Leiden: Brill, 1996.

Fackenheim, Emil L. The God within: Kant, Schelling, anc histo iciè ed. by John Burbidge. University of Toronto Press, 1996.

Harris, W. Hall. The descent of Christ: Ephesians 4:7-11 and traditional Hebrew imagery. Leiden: E.J. Brill, 1996.

Hoffman, Daniel L. The status of women and gnosticism in Irenaeus and Tertullian. Lewiston: Edwin Mellen, 1995. 


\section{Chronicle}

Jacobson, Howard. A commentary on pseudo-philo's "Liber Antiquitatum Biblicarum" with Latin text and English translation. 2 v. Leiden: Brill; 1996.

Protestant history and identity in sixteenth-century Europe edited by Bruce Gordon. 2 v. London: Scolar Press, 1996.

Reception of the Fathers in the West edited by Irena Backus. 2 v. Leiden: E.J. Brill, 1996.

\section{Canadian Imperial Bank of Commerce}

This gift is designated specifically for the development of our foreign language collection.

Amadis de Gaula. Madrid: Turner, 1997.

Aristotle. Analytica Posteriora übersetzt... von Wolfgang Detel. 2 Bde. Berlin: Akademie Verlag, 1993.

Apuleius. Pro se de magia: apologia. Amsterdam: J.C. Gieben, 1997.

Autos Sacramentales. Madrid: Turner, 1996.

Becquer, Gustavo Adolfo. Obras completas. Madrid: Turner, 1995-97.

Bosna i Hercegovina od Srednjeg Veka do Novijeg Vremena. Beograd: Istorijski institut SANU; Novi Sad: Pravoslavna rec, 1995.

Bruckenschlage: Eine barocke Festgabe fur Ferdinand van Ingen. Amsterdam: Rodopi, 1995.

Codice feudale della serenissima repubblica di Venezia. Bologna: Forni, 1970.

Codices hebraicis litteris exarati quo tempore scripti fuerint exhibents, vol. 1. Turnhout: Brepols, 1998.

Dictionnaire Francois... - Genève: Slatkine Reprints, 1994.

Es ist viel "Hitler" in Wagner. Tübingen: Niemeyer, 1996.

Ehls, Marie-Luise Protest und Propaganda: Demonstrationen in Berlin zur Zeit der Weimarer Kepublik. Berlin: de Gruyter, 1997. (Veröffentlichungen der Historischen Kommission zu Berlin).

Dante Alighieri. Gassman legge Dante (videorecording). Roma: PPM: Bologna: EDB, 1996.

Doderer, Heimito von, Tagebücher 1920-1939. Munchen: C.H. Beck, 1995.

Encina, Juan del. Obras completas. Madrid: Turner, 1995.

Gilbert de Poitiers et ses contemporains... Napoli: Bibliopolis, 1987. (History of logic, 5).

Goll, Yvan. Die Lyrik in vier Banden. Berlin: Argon, 1996.

Goris, Wouter. Einheit als Prinzip und Ziel: Versuch über die Einheitsmetaphysik des Opus... Ickharts. Leiden: Brill, 1997. (Studien und Texte zur Geistesgeschichte des Mittelalters, 59).

Harnack, Adolf von. Adolf von Harnack als Zeitgenosse... Walter de Gruyter, 1996.

Historia General del Peru. Lima: Brasa, 1994. 


\section{Chronicle}

I Libri dei Leoni: la nobilta di siena in eta medicea: 1557-1737. (Siena): Monte dei Paschi di Siena, 1996.

Luis, de Granada. Obras castellanas. vol. 1. Madrid: Turner, 1994-

Justiz und NS-Verbrechen. Sammlung deutscher strafurteile Wegen N.S. Tö̈tings... hrsg. von A.L. FiüterEhlermann \& C.F. Rüter. 22 Bde. Amsterdam, 1968-1981.

Kitve Maharal. Jerusalem: s.n., 1986-1987.

Melendez Valdes, Juan. Obras Completas. Madrid: Turner/Castro, 1996.

Orazio: enciclopedia oraziana. Roma: Istituto della Enciclopedia Italiana 1996-.

Procès Verbaux du Comité d'Instruction Publique de l'Assemblé Législative et de la Convention ivationale. 9 vols. Paris: Harmattan, 1997.

Salvadore, Tommaso. Le Opere di Orazio Recate in Versi Italiani. Napoli: Edizioni Scientifiche Italiane, 1993.

Torquemada, Antonia de. Obras completas, vol. 1-2. Madrid: Turner, 1994.

Valdes, Alfonso De. Obra Completa. Madrid: Turner, 1996.

Wilamovitz-Moellendorf, Ulrich von. Aristoteles und Athen. 2 Aufl. Weidmann, 1966, repr. 1985.

Wilson, John … Schelling und Nietzsche... Berlin: de Gruyter, 1996.

Wittgenstgein, Ludwig. Wiener Ausgabe. Band 3. Springer, 1995.

\section{Clifford and Joan Hatch Library Fund}

Aertsen, Jan; Medieval Philosophy and the Transcendentals. Leiden; New York: E.J. Brill, 1996.

Aertsen, Jan: Nature and Creature. Leiden; New York: E.J. Brill, 1988.

Alexander of Aphrodisias: In VIII libros topicorum Aristotelis commentario. Stuttgart-Bad Cannstatt: Frommann-Holzboog, 1996.

Archivio della tradizione lirica da Petrarca a Marino. [Roma]: Lexis progetti editoriali, [1997].

Carson-Berndsen, Julie: Time-Map Phonology. Dordrecht; Boston: Kluwer, 1998.

Case, Typology and Grammar: in Honor of Barry J. Blake. Amsterdam; Philadelphia: J. Benjamins, 1998.

Centauren-Gebürten: Wissenschaft, Kunst und Philosophie beim jungen Nietzsche. Berlin; New York: W. de Gruyter, 1994.

Cultural Economics: the Arts, the Heritage, and the Media Industries. 2 vols. Theltenham, UK; Lyme, NH:E. Elgar Pub., 1997.

Dik, Simon C.: The Theory of Functional Grammar. Berlin; New York: Mouton de Gruyter, 1997.

Floridi, Luciano: Scepticism and the Foundation of Epistemology: a study in the metaiogical fallacies. Leiden; New York: E.J. Brill, 1996. 


\section{Chronicle}

Formal Ontology. Kluwer Academic Publishers, 1996.

Frege: Importance and Legacy. Berlin; New York: Walter de Gruyter, 1996.

Hobbes: war among nations. edited by Timo Airaksinen and Martin A. Bertman. Aldershot, Hants, Engianc; Brookfield, Vt. U.S.A.: A vebury, c1989.

Hofmann, Johann Nepomuk: Wahrheit, Perspektive, Interpretation: Nietzsche und die philosophische Hermeneutik. Berlin; New York: Walter de Gruyter, 1994.

Lindberg, David C.: Roger Bacon and the Origins of Perspectiva in the Middle Ages: a critical edition and English translation of Bacon's Perspectiva, with introduction and notes. Oxford: Clarendon Press; New York: Oxford University Press, 1996

Ludwig Wittgenstein: Critical Assessments. 5 vols. London; New York, N.Y.: Routledge, 1996, c1986.

Metais and Monies in an Emerging Global Economy. Aldershot, Hampshire, Great Biritain; Brookfield, Vt.: Variorum, 1997.

Morrell, Jack: Science, Culture, and Politics in Britain, 1750-1870. Âldershot, Great Britain; Brookfield, Vt., USA: Variorum, 1997.

Natural Kinds, Laws of Nature and Scientific Methodology. Dordrecht; Boston: Kluwer Academic Publishers, 1996.

Plato: Critical Assessments ed. by Nicholas Smith. 4 vols. London; New York: Routledge, 1998.

Shakespeare, William: The Plays, Johynson-Steevens edn, 12 vols. London: Routledge/Thoemmes, 1995.

Socrates: Critical Assessments edited by William J. Prior. London; New York: Routledge, 1996.

Studies on the History of Logic: Proceedings of the III. Symposium on the History of Logic. Berlin; New York: Walter de Gruyter, 1996.

\section{Hans and Eugenia Jütting Fund}

The donations of Hans and Eugenia Jütting have enabled us, over the past few years to make valuable additions to both the Polish and German collections.

\section{$\underline{\text { Polish }}$}

Fifty-two individual inonographs, in the areas of Polish history and literature, were selected in Gdansk by Stefan Wladysiuk, the Librarian of the Polish Institute. In addition to this, a number of English language titles on Polish subjects were purchased.

Conant, Roger: Poland: 1000 Years of History and Culture, (video-recording), JAM, 1996.

Czepiel, Tomasz M.M.: Music at the Royal Court and Chapel in Poland. Garland, 1996.

Kubik, Jan: The Power of Symbols Against the Symbols of Power, the Rise of Solidarity and the Fall of State Socialism in Poland. Pennsylvania State University Press, 1994. 


\section{Chronicle}

Kurcrewski, Jacek: The Resurrection of Rights in Poland. Oxford U.P., 1993.

Kurek-Leslie, Ewa: Your Life is Worth Mine: How Polish Nuns Saved Hundreds of jewish Children in German-occupied Poland, 1939-1945. Hippocrene Books, 1997.

Lerski, George J.: Historical Dictionary of Poland, 966-1945. Greenwood Press, 1996.

Najder, Zdzislaw: Zycie Conrada-Korzeniowskiego. Alfa, 1996.

Okonski, Walter: Wartime Poland 1939-1945: a Select Annotated Bibliography of Books in English. Greenwood Press, 1997.

Roberts, Kenneth: Poland's First Post-Communist Generation. A vebury, 1995.

Staar, Richard F.: Transition to Democracy in Poland. St. Martin's Press, 1993.

The Unplanned Society: Poland during and after Communism. Columbia Univ. Press, 1992.

Weclawowicz, Grzegorz: Contemporary Poland: Space and Society. Westview Press, 1996.

Wightman, Alistair: Karlowicz, Young Poland and the Musical Fin-de-Siecle. Scolar Press, 1996.

Wolff, Larry: The Vatican and Poland in the Age of Partitions: Diplomatic and Cultural Encounters of the Warsaw Nunciature. Columbia Univ. Press, 1988.

\section{German}

Bohme, Jakob: Werke. Deutscher Klassiker Verlag, 1.996.

Bibliothek des Mittelalters: Texte und Übersetzungen vierundzwanzig Bände mit 1llustrationen. Bd. 1-4, 8-9, 13-15, 20-21, 23. Deutscher Klassiker Verlag, 1987-

Goethe, Johann Wolfgang von: Werke, ed. Deutscher Klassiker Verlag, 1986.

Hauptmann, Gerhart: Sämtliche Werke, Centenarausgabe, ed. H.-E. Hass. Propyläen, 1996.

Scherffer von Scherffenstein, Wencel: Geist-und-weltsliche Geschichte. Niemeyer, 1997.

Walser, Martin: Werke in zwölf Banden. Suhrkamp, 1997.

\section{Seagrams (Canadiana)}

Canada. Royal Commission on Aboriginal Peoples. 5 vols. Ottawa: The Commission, 1996.

Canadian Institute for Historic Microreproduction. A collection of paper reprints of historical material selected from the CIHM database.

A collection of unique pamphlet material relating to the CCF and the Saradian Socialist Movement.

Gallup. (microfilm) 1941-1960 Toronto: Gallup Canada Inc., 1987-i985.

The Ottawa Citizen. (microfilm) 1992-1997 Ottawa, Ont.. Southam, 1843. 


\section{Trigg}

China in the 21st Century. 4v. Cambridge, MA,: Foundation for China in the 21st Century, 1995-

Showa Shi. 22v. History of the Showe Tapar. Tokyo: Mainichi Shinbunsha, c1984-1989 History of the Showa period, Japan.

\section{Webster (Religious Studies)}

A companion to the philosophy of religion editeu by Philip L. Quinn and Chorles Taliaferro. Oxford: Blackwell, 1997.

Cruz, Eduardo. A theological study informed by the thought of Paul Tillich and the Latin American experience: the ambivalence of science. Lewiston: Edwin Mellen, 1996.

Encyclopedia of religious controversies in the United States edited by George H. Shriver and Bill J. Leonard. Westport, Conn.: Greenwood Press, 1997.

Fossum, Jarl E. The image of the invisible God: essays on the influence of Jewish mysticism on early Christology. Freiburg: Universitätsverlag, 1995.

Hamilton, Sue. Identity and experience: the constitution of the human being according to early Buddhism. London: Luzac Oriental, 1996.

Ledek, Ronald. The nature of conscience and its religious significance with a special reference to John Henry Newman. San Francisco: International Scholars Publications, 1995.

Rush Rhees on religion and philosophy edited by D.Z. Phillips... Cambridge: University Press, 1997

Streland, Rick. Paul, Artemis and the Jews in Ephesus. Berlin: Walter de Gruyter, 1996.

Valentine, Simon Ross. John Bennet and the origins of Methodism and the Evangilical revival in England. Lanham, Md.: Scarecrow Press, 1997.

Vasquez, Manuel A. The Brazilian popular church and the crisis of modernity. Cambridge University Press, 1998.

\section{Wong}

Chung Kuo Ping Shu chi Cheng. Pei-ching shih: Chieh fang choun chÂu pan she; Shen-yang shih: Liao Shen shu she, 198- (Missing volumes from a $50 \mathrm{v}$. set of early works of military art and science in China. In Chinese.)

Ta Tsang Ching. 15lv. T'ai-pei shih: Hsin wwen feng ch'u pan kung SSU, Min kuo 72 (1983) Buddhist sacred works. 


\section{Chronicle}

\section{Other Titles Purchased in 97/98 with Special Funds}

The Aristocracy, the State 8 the Local community: the Hastings Collection of Manuscripts from the Huntington Library in California. (microform). Sussex, England: Harvester Microform, 1986. Over five centuries of activity in national and regional affairs are traced in the Hastings family manuscripts. Includes correspondence dated 1477 to 1828 providing insight into military affairs, taxation, elections, Jacobite politics, plantations in America, the American Revolution, the Napoleonic Wars, marriages, estate matters, debts and education. Also includes a series of accounts of financial papers which illuminate estate and household operations from the middle ages to the $19^{\text {th }}$ century.

Ancient correspondence 1175-1538: PRO class SC 1. (microform) Brighton, Sussex: Harvester Microform, 1985. The "Ancient Correspondence Class" is reproduced here in its entirety. Spanning the reign of King John to King Henry VIII, it incledes the correspondence of kings, bishops, popes, knights, nobelmen, royal servants and lords chancelor. Principally assembled from documents formerly held in the Tower of London, the "Ancient Correspondence Class" is comparable in breadth and in detail to the later State Paers series.

The British in Ireland: Dublin Castle Records. Series 1. (microform). Sussex, Eng.: Harvester Microform Publications, 1982-1985. This microfilm collection makes available central original materials documenting the British presence and control in Ireland in the late nineteenth and early twentieth centuries.

Conference on Security and Cooperation in Europe: basic documents, 1993-1995. Edited by Arie Bloed. Netherlands: Martinus Nijhoff, 1997.

Conference on Security and Cooperation in Europe: analysis and basic cocuments, 1972-1993. Edited by Arie Bloed. Netherlands: Europa, 1993.

Early English Books, 1641-1700. (microfilm) Units 93-103. Ann Arbor, Mich.: University Microfilms, 1990.

Early Printed Bibles selected sections: (microform). Leiden, Netherlands: Inter Documentation Co., 1988(1995).

Evans Early American Imprints. (nicroform) (New Canaan, Conn.): Readex, (1996).

Great Britain. House of Commons. s'arliamentary Papers. 1901-1908. London: Chadwyck-Healey, 1996.

International Medieval Bibliography (computer file). Leeds, U.K.: International Medieval Institute; Turnhout: Brepols Publishers, 1995.

The Nation. (microfilm) 1953-1980.

New German Critique. Milwaukee. 1974-. 48 vandalized issues ranging fiom 1974 through 1993 have beexi re-placed.

Presidential Office Files. (microfilm). Presidents Franklin D. Roosevelt, Harry S. Truman, Dwight D. Eisenhower and John F. Kennedy.

Royal Archives at Windsor Castle: Victorian photographs and associated materials, 1845-1909. (microform) Collection of 3,100 documents covers changes of government, cabinet reconstruction and political crises in Britain, 1837-1901. Includes the entire reign of Queen Victoria, the Bedchamber Crisis in 1839, the defeat of Peel in 1846, the difficulties of Cabinet-making in the 1850's, Gladstone's resignation in 1873, the constitutional crises of 1884 and 1886 and the reconstruction of Lord Salisbury's Cabinet in 1900.

Rhodes House Library Oxford. Slave Trade Papers. (microform) Oxford: Bodleian Library, 1963. As heir to anti-slavery leader William Wilberforce, Sir Thomas Fowell-Buxton's papers provide unique insight into 


\section{Chronicle}

the development of the Victorian social conscience and the worldwide significance of the great anti-siavery

campaign. Supplies fundamental material for the study of the international phenomenon of slavery, the colonization, "Christianization" of Africa and the Empire, and the parliamentary and extra-parliamentary history of the abolitionist movement. The Calendar of the Papers of Sir Thomas Fowell-Buxton, 1786-1845 serves as a guide, also reproduced on the first reel.

Sixteenth and Seventeenth Century Manuscripts from the Rawlinson Collection (microform) Reading, England; Woodbridge, Ct.: Research Publications Ltd., 1993.

Unpublished Records of the Established Church of England 1540-1720: the Gibson, Fairhurst, and Henry VIII divorce papers from Lambeth Palace Library, London (microform). Brighton, Sussex, England: Harvester Microform, 1985. The great clashes between Church and State, Protestants and Catholics, the King and Rome, are extensively documented in this collection of previously unpublished volumes from Lambeth Palace Library.

Verhandlungen des Reichstags (microfilm) 1918-1920. Berlin: Reichsdruckerei, 1919-

\section{Electronic Resources New or Upgraded in $97 / 98$}

Anthropolotical Literature

Archivia... Aboriginal Peoples

Archive RGALI (Russian State Archive of Literature and Art)

Avery Index to Architecture Periodicals

Bibliography of the History of Art

Britannica Online

British Humanities Index

Canadian Research Index

Canadian \& World Encyclopedia

Dir: Dizionario italiano ragionate

Dyabola.

English Short title Catalogue

Environmental Sciences \& Pollution Management Database (consists of 12 databases)

Francis (French language) [computer file]. [S.I.]: CNRS, J. Paul Getty Trust, 1996-

Global Development Finance (World Bank)

Handbook of Latin American Studies 1990-

Hispanic American Periodicals Index 1970-

History of Science \& Technology

Index to the House of Commons Parliamentary Papers... 1801-

Index Translationum

Industrial Monitor (Statistics Canada)*

Interational Medieval Bibliography

Jahresberichte fur deutsche Geschichte

JSTOR (fill-text electronic journals)

Library Literature

Lira (Litteratura Italiana)

Nineteenth Century Short Title Catalogue

OED CD-ROM 2d ed

Project MUSE (full-text electronic journals)

Le Robert electronique

Russian National Bibliography Plus 


\section{Chronicle}

World News Connection

World Shakespeare Bibliography

World Development Indicators (World Bank)

World Trade Database (Statistics Canada)*

*Received as part of the Data Liberation Initiative (DLI)

\section{Osler Library of the History of Medicine}

\section{Recent acquisitions to the library include the following:}

Four books by Thomas Willis, Professor of Natural Philosophy at Oxford from 1660 to 1675, presented by Dr. William Feindel. These comprise the third edition of Defermentione, de febribus, de urinus (ij62); Disseriation sur les urines (French edition) (1683); A plain and easie method for preserving [by God's blessing] those that are well from the infection of the Plague, or any contagious distemper, in city, camp, fleet, etc., and for curing such as are infected with it (1691); and Opera omnia, published in Geneva in 1676.

In November 1996 Dr. Robert Nicholls of Merrickville, Ontario and his daugher Dr. Eleanor Nicholls Curwood of Montreal, presented two rare books to the library:

Malpighi, Marcello. Opera omnia...tomis duobus comprehensa... Londini, Prostant apud Robertum Scott, 1686.

Chabrey, Dominique. Stirpium icones et sciagraphia.. Genevae, Typis Phil. Gamoneti \& Jac. de Ia Pierre, 1666.

Professor Emeritus T.L. Sourkes, author of Nobel Prize Winners in Medicine and Physiology, 1901-1965 (London \& N.Y., Abelard-3chuman, 1966), presented related files to the Library’s archives.

Dr. M.H. Friedman, of Lansdowne, Pa. donated more Boris Babkin (1877-1950) material, now amalgainated with his previous donation

Dr. Charles S. Bryan, of the University of South Carolina School of Medicine, Columbia, S.C., presented an inscribed copy of his book Osler: Insnirations from a Great Physician, Oxford Univ. Press, 1997.

Ms. Sonya d'Errico, of the Scuola Speciale per Archivisti e Bibliotecari, Università "La Sparienza", Italy, presented a bound copy of her illustrated thesis Sir William Osler bibliofilo, 1997.

Dr. Akitomo Matsuki, of the University of Hirosaki School of Medicine, Japan, presented a copy of his facsimile edition of John Snow's On Chloroform and other Anaethetics, London, 1858.

Dr. Marcellino Amasuno presented a copy of Joseph G. Richardson's Medicology, or Home Encyclopedia of Health, New York, Philadelphia, London, University Medical Society, 1904.

Dr. William C. Gibson presented copies of two of his recent publications: Medical Comets: Scholarly contributions by medical undergraduates, University of British Columbia Alumni Association, 1998; and No Time to Slow Down (Dr. Gibson's autobiography) U.B.C. Alumni Association, 1996. 


\section{Chronicle}

Dr. Richard Golden presented the 1997 Addenda to his 1988 publication Sir William Osler: an annotated bibliography with illustrations, San Francisco, Norman Pub.

\section{Physical Sciences \& Engineering Library}

The Library is grateful for the Webster Foundation grant that was used again to purchase most of its books. $\$ 8,000$ was granted by the Faculty of Engineering to acquire books for the forthcoming Masters program in Manufacturing Management.

Some recent arquisitions for the Mossman Collection of the History of Science and of Ideas:

-The origins of modern philosophy of science, 1830-1914. London: Routledge/Thoemmes Press, 1996, 12 volumes.

-Parker, L.H., Rennie, L.J., Fraser, B.J., eds. Gender, science, and mathematics: shortening the shadow. Dordrecht; Boston: Kluwer Academic, 1996.

-Nielson, G.M. Scientific visualization: overviews, methodologies, and techniques. Los Alamitos, CA: IEEE Computer Society, 1997.

-Dahl, P.F. Flash of the cathode rays: a history of J.J. Thomson's electron. Bristol; Philadelphia, PA: Institute of Physics, 1997.

-Singh, S. Fermat's last theorem: the story of a riddle that confounded the world's greatest minds for 358 years. London: Fourth Estate, 1997.

-Hentschel, K. The Einstein Tower: an intertexture of dynamic construction, relativity theory, and astronomy. Stanford, CA: Stanford University Press, 1997.

-Phillips, J.L. The bends: compressed air in the history of science, diving, and engineering. New Haver, CO; London: Yale University Press, 1998.

-Gavaghan, H. Something new under the sun: satellites and the beginning of the space age. New York: Copernicus, 1998.

\section{Additions to the reference collection:}

-European sources of scientific and technical information. Harlow, Essex: Longman; Detroit, MI: Distributed by Gale Research, 12th ed, 1996.

-Rigden, J.S. ed. Macmillan encyclopedia of physics. New York: Macmillan, 1996, 4 volumes.

-Salamone, J.C. ed. Polymeric materials encyclopedia. Boca Raton: CRC Press, 1996, 12 volumes.

-Crocker, M.J. ed. Encyclopedia of acoustics. New York: Wiley, 1997, 4 volumes.

-Nalwa, H.S. ed. Handbook of organic conductive molecules and polymers. Chichester; New York: Wiley, 1997,4 volumes. 


\section{Chronicle}

-Meyers, R.A. ed. Encyclopedia of environmental analysis and remediation. New York: Wiley, 1998, 8 volumes.

\section{Mossman Centenary Exhibition}

The centenary exhibition Dr. Donald D. Mossman: Collector and Philanthropist was held in the Redpath Library exhibition area from March 16th to April 30th, 1998 (with an extension to May 4th, 1998).

The legacy of Dr. Mossman lives on at McGill in his collection of books on the history of science and in the lecture series he founded to further the understanding of science and of ideas.

Dr. Mossman was born in Montreal in 1898. He studied chemistry at McGill in the '20s. Though he went on to graduate degrees elsewhere and subsequently taught chemistry at Hunter College in New York, his allegiance lay with McGill, his first alma mater. In 1974 he donated his collection to McGill. The 1,700 books can be found in the Physical Sciences \& Engineering Library. His generosity did not stop there. In 1981, he donated $\$ 100,000$ to maintain and further develop the Mossman Collection, to encourage teaching and research in the history of science and of ideas, and to establish two public lectures a year by scholars in the field.

The 13 exhibition cases displayed Dr. Mossman's degrees, certificates, and other memorabilia. Laboratory equipment from the '20s was graciously lent by the Department of Chemistry. Letters, memoranda, minutes of the Mossman Committee, photographs, and a sample of the Mossman collection (old and new) were also included. Posters and handouts from various Mossman lectures showed that invited scholars came from a variety of research fields.

The centenary exhibition was a celebration of Dr. Donald Davis Mossman - his achievements and his legacy. This legacy continues to inspire and inform generations of students and teachers at McGill. 



\section{Contributors}

Christina-Anne Boyle received a B.A. and a Master's degree in Library and Information Studies from McGill. Since graduating in 1992, she has been employed as a public librarian, and as a historical manuscripts cataloguer for a private collector. She is currently registered in the M.A. program in the Department of History, and is in the final stages of completing her thesis analyzing the peerage of early modern Scotland in the reign of King James VI.

Maria L. Brendel, a Ph.D. candidate at McGill University, is currently completing her thesis entitled Allegorical Truth-telling via the Feminine Baroque: Ruben's Material Reality. She holds an M.A. in Art History (McGill) and a Diploma in Museum Studies (University of Southern California, Los Angeles). She has contributed to Fontanus, vol. viii (1995), "Deluxe Devotional Prayer Books: a McGill Book of Hours;" other publications include essays for the exhibition catalogue Isaac Cruikshank and The Politics of Parody: Watercolors from the Huntington Collection, Huntington Library, San Marino, California (1994); 'Rubens' paradiso terrestre" in Post: Nomadisme et Trafic Des Cultures (1996); and two exhibition reviews in Canada's contemporary art journal Parachute: "Linda Giles," vol. 82 (1996), and "Uncommon Sense," vol. 89 (1998).

Montague Cohen was born in London, England and obtained his B.Sc. (Physics) and Ph.D. (Medical Physics) from London University. Before coming to Canada in 1975, he worked at The London Hospital in London and the International Atomic Energy Agency in Vienna. In 1979 he set up the Medical Physics Unit of McGill University and directed the Unit until his retirement in 1991. He now holds a post-retirement Professorship in the McGill Physics Department and is also Honorary Curator of the Rutherford Museum. He has been a member and/or Chairman of several task groups of the International Commission on Radiation Units and Measurements (ICRU), and a consultant on radiation safety to the Ontario Government.

Adam Gacek, a native of Poland, received his M.A. in Oriental Philology from the Jagiellonian University, Cracow, and subsequently a post-graduate diploma in Library Science from the Polytechnic of North London. He worked at the School of Oriental and African Studies, University of London, and the Institute of Ismaili Studies, London, and is the author of two catalogues of Arabic manuscripts for the above institutions. He is also the author of a growing number of articles on Arabic palaeography and codicology and is a co-editor of a unique annual publication, Manuscripts of the Middle East. In 1987 he joined McGill University, where he occupies the position of Head Librarian of the Islamic Studies Library. Since then he has contributed to three previous issues of Fontanus and has published two catalogues of Arabic manuscripts and Arabic lithographed books in the Fontanus Monograph series.

Hervé Gagnon détient des diplôme de maîtrise et de doctorat en histoire ainsi qu'une maitrise en muséologie. Depuis plusieurs années, il explore l'histoire des musées au Québec. Il s'intéresse de près aux idéologies au Québec au XIXe siècle et à leurs principaux moyens d'expression. Il occupe présentement le poste de directeur-conservateur du Musée Colby-Curtis à Stanstead (Québec). Il est aussi professeur associé au Département d'histoire et de sciences politiques de l'Université de Sherbrooke et chargé de cours à l'Université Bishop's. 
John Hobbins obtained his B.A. (Hons. History, 1966) and his M.L.S. (1968) from McGill University. Since then he has worked for the McGill University Libraries as Reference Librarian, Instructional Services Librarian, Head of Interlibrary Loan, Head of Acquisitions, Central Technical Services, and Acting Law Area Librarian. He is currently Associate Director of Libraries with a special responsibility for Systems and Technical Services. He is a former contributor to Fontanus, including one article based on the Humphrey papers.

Peter F. McNally is an Associate Professor in the Graduate School of Library and Information Studies where he lectures and publishes in the area of Bibliography, Reference Service, and the History of Books, Printing and Libraries. He is Executive-Secretary of the James McGill Society, Convenor of the Library History Interest Group of the Canadian Library Association, and President-elect of the Bibliographical Society of Canada. Among his most recent publications are, Readings in Canadian Library History 2, (Ottawa, CLA, 1996), and (with Kevin Gunn) "The McGill University Catalogue of 1876; a Preliminary Analysis," Fontanus: from the Collections of McGill University (v. 9, 1996).

George Thomson was born in Dunblane, Scotland, the ancestral nephew of Professor McEachran. He graduated in design from Edinburgh College of Art and gained a doctorate in biological sciences from the University of Stirling. His thesis involved studies in several fields including genetics, zoological systematics and computer graphics. This multi-disciplinary approach has been a theme of later research. After several years as a lecturer in Graphic Communication at Glasgow School of Art, teaching, lettering, typography and information design, he was appointed to the staff of Cumbria College of Art and Design, Carlisle, England where he is now Leader of Academic Research. Dr. Thomson holds Fellowships of the Society of Scribes and Illuminators and the Royal Entomological Society and is an elected member of several other learned societies. His publications include many academic papers and several books and thesis in the fields of entomology, education, genealogy and local history. He is currently engaged in research on pre-1855 lettering on Scottish gravestones.

Stephen J. Toope is Dean of the Faculty of Law at McGill University. A graduate of Harvard and McGill, he also holds a doctoral degree in international law from Cambridge. His scholarly interests include international dispute resolution, international human rights law and international environmental law. Professor Toope has served as the Chair of the Board of a Canadian-based relief and development NGO, and regularly serves as a consultant to the Canadian Department of Foreign Affairs and the Canadian International Development Agency. His work with Professor Jutta Brunnée on the interplay between international environmental law and international relations theory was recently awarded the Francis Déak prize of the American Society of International Law.

Ali Yaycioglu, born and raised in Ankara, Turkey, is a Ph.D. research student at the Institute of Islamic Studies, McGill University. He has been working on Ottoman legal culture, legal language and manuscript tradition, with an emphasis on Ottoman fetva compilations and court registers. This research has resulted in a number of articles about to appear in such journals as Kebikec and The Journal of Ottoman Studies. Mr. Yaycioglu is also a member of the Research Group based at the University of Chicago working on the history of the Black Sea trade. 


\title{
Fontanus Publications
}

\author{
FONTANUS (journal)
}

v.1 1988

v. $2 \quad 1989$

v.3 1990

v.4 1991

v.5 1992 Montreal 350th Anniversary Issue

v.6 1993 Redpath Issue

v.7 1994 Stephen Leacock Issue

v. 81995 Women in the University Issue

v.9 1996 McGill 175th Anniversary Issue

v.10 1998 Rutherford Centenary Issue

\section{FONTANUS MONOGRAPH SERIES}

I Adam Gacek, Arabic Manuscripts in the Libraries of McGill University, Union Catalogue, 1991

II Calvin Evans, Sõren Kierkegaard Bibliographies: Remnants 1944-1980 and Multi-Media, 1925-1991, 1993

III Barbara Lawson, Collected Curios: Missionary Tales from the South Seas, 1994

IV John Hobbins, On the Edge of Greatness: The Diaries of John Humphrey, First Director of the United Nations Division of Human Rights, Vol. 1, 1948-1949, 1994

V Max Dunbar, Essays from a Life: Scotland, Canada, Greenland, Denmark, 1995

VI Alberto Pérez-Gómez and Louise Pelletier, Anamorphosis: An Annotated Bibliography with Special Reference to Architectural Representation, 1995

VII Adam Gacek, Arabic Lithographed Books in the Islamic Studies Library, McGill University, Descriptive Catalogue, 1996

VIII Irena Žantovská Murray, Sources in Iconography in the Blackader-Lauterman Library of Architecture and Art, McGill University, An Annotated Bibliography, 1996

IX John Hobbins, On the Edge of Greatness: The Diaries of John Humphrey, First Director of the United Nations Division of Human Rights, Vol. 2, 1950-1951, 1996

X Joan C. Bevan and Maria A. Pacelli, The Quintessential Canadian Anaesthetist: Wesley Bourne. A Retrospective on the Foundations of McGill Anesthesia, 1996

XI Goldie Sigal, A Garment Worker's Legacy: The Joe Fishstein Collection of Yiddish Poetry, 1998

XII John Hobbins, On the Edge of Greatness: The Diaries of John Humphrey, First Director of the United Nations Division of Human Rights, Vol. 3, 1952-1957, 1998

Orders may be placed at:

Marketing Department

McGill-Queen's University Press

3430 McTavish Street

Montreal QC

Canada H3A 1X9 



\title{
Guidelines for Authors
}

Fontanus is an annual publication devoted to scholarly research based principally upon McGill University collections. The term 'collections' is interpreted in the broadest sense, to include books, archives, specimens, artifacts, buildings and other forms of documentary evidence. Contributions derived from all aspects of McGill collections will be considered. Submission of a contribution is understood to imply that no paper containing essentially the same material has been published previously and that the manuscript is not under editorial consideration elsewhere. All submissions will be reviewed by members of the Editorial Board and refereed by experts in the appropriate field. Any substantial changes will be cleared with the author before publication. Send submissions, prepared according to the instructions below, to:

\author{
Dr. Montague Cohen \\ Editor, FONTANUS \\ Rutherford Physics Building \\ 3600 University Street \\ Montreal, Quebec, H3A 2T8 \\ phone: (514) 398-7498 \\ fax: (514) 398-8434
}

\section{Form of Manuscript}

All manuscripts (in two copies) must be typewritten and double-spaced. Articles may also be submitted on computer disk, using WordPerfect 4.2, 5.0 or 5.1 software. Notes should be numbered consecutively and follow the text of the article. Author's name should appear after the title and before the text of the article. A short biographical note of no more than 200 words should be included. Degrees, current and previous positions and major publications should be noted.

\section{Abstracts}

A brief abstract (of no more than 200 words) of the content of the article should be prepared by the author.

\section{Form of Citation}

Manuscripts should conform to the standards outlined in The Canadian Style: a guide to writing and editing (by the Department of the Secretary of State of Canada) Toronto, London: Dundurn, 1985. Translation of passages in other than French or English should be provided in the text.

\section{Illustrations}

Photocopies of visual material (with brief captions) must be submitted by authors for initial evaluation. Once an article has been accepted, the author is responsible for supplying clear black and white glossy photos and for securing the permission to publish copyright material if necessary.

Fontanus is published each calendar year. Articles submitted before December 15 are eligible for consideration for the following year's issue. Authors will have the opportunity to review their manuscripts after editing has been completed. 
